UNIVERSIDADE DE SÃO PAULO
INSTITUTO DE GEOCIÊNCIAS

\title{
GEOMORFOLOGIA E GEOESPELEOLOGIA DO CARSTE DA SERRA DA BODOQUENA, MS
}

\author{
WILLIAM SALLUN FILHO
}

Orientador: Prof. Dr. Ivo Karmann

TESE DE DOUTORAMENTO

COMISSÃO JULGADORA

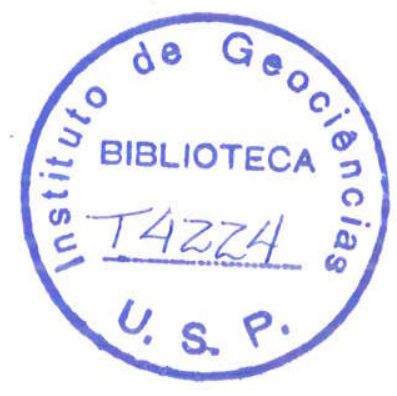

Nome

Presidente: Prof. Dr. Ivo Karmann

Examinadores: Prof. Dr. Augusto Sarreiro Auler

Prof. Dr. Claudio Riccomini

Dr. José Antonio Ferrari

Dr. Luís Beethoven Piló

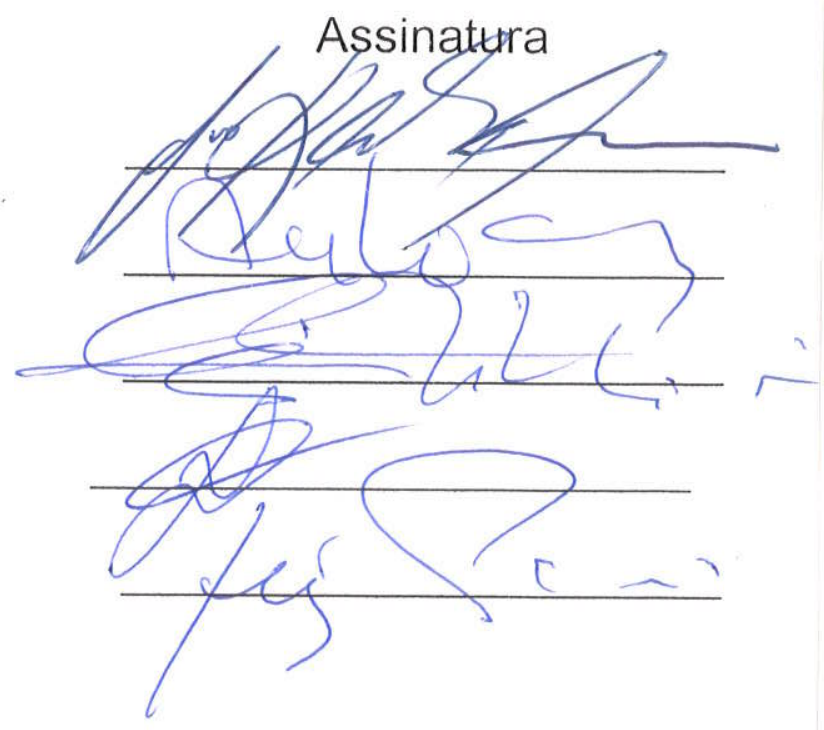

SÃO PAULO

2005 
UNIVERSIDADE DE SÃO PAULO

INSTITUTO DE GEOCIÊNCIAS

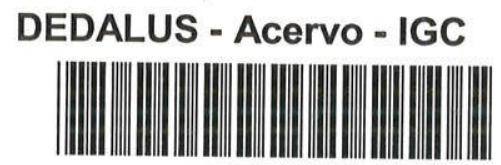

30900016053

\section{GEOMORFOLOGIA E GEOESPELEOLOGIA DO CARSTE DA SERRA DA BODOQUENA, MS}

William Sallun Filho

Orientador: Prof. Dr. Ivo Karmann

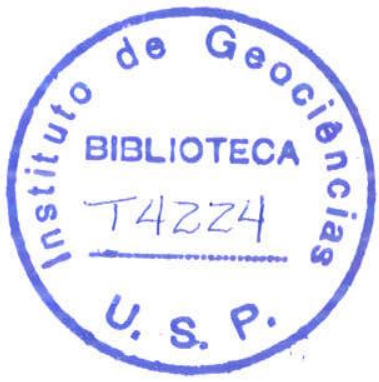

\section{TESE DE DOUTORAMENTO}

Programa de Pós-Graduação em Geoquímica e Geotectônica

SÃO PAULO

2005 
Nada mais que a canção disto. Como se

só o canto tivesse

nos trazido até este lugar.

Temos estado aqui, e nunca estivemos aqui.

Estivemos a caminho até o lugar onde começamos,

e estivemos perdidos.

Não há fronteiras

na luz. Ea terra

não nos deixa palavra alguma

pra cantar. Pois o desmoronar da terra

sob os pés

é música em si, e caminhar entre estas pedras

é ouvir a gente mesmo

apenas.

Canto, logo, nada,

como se isso fosse o lugar

para onde não volto -

e se voltasse, descontava a minha vida

nessas pedras: esquecer

que um dia estive aqui. O mundo

me caminha

além do meu alcance.

Paul Auster, "Pedreira", em Fragments from the Cold (1976-1977), Tradução de Rodrigo Garcia Lopes (Folha de São Paulo) 
À minha esposa Alethéa e aos meus pais. 
AGRADECIMENTOS

Gostaria de agradecer a todos que contribuíram de alguma forma, para realização deste trabalho e me desculpo de antemão se por algum esquecimento.

Agradeço ao Prof. Dr. Ivo Karmann, pela orientação, apoio e amizade, desde minhas primeiras "cavernadas" no primeiro ano de graduação até o final desta tese de doutorado.

Ao curso de Pós-Graduação do Instituto de Geociências da Universidade de São Paulo, especialmente ao Programa de Geoquimica e Geotectônica pela possibilidade de realizar este trabalho e pelo apoio concedido.

A FAPESP pelo financiamento das pesquisas através de Auxilio à Pesquisa concedido ao Prof. Dr. Ivo Karmann (proc. $n^{\circ}$ 01/07481-7).

Ao Centro Nacional de Estudos, Proteçăo e Manejo de Cavernas (CECAV-IBAMA) pelo apoio na expedição das licenças de coleta, através do Chefe Ricardo Marra. Um agradecimento especial a Gerência Executiva do IBAMA-MS, através do Sr. Nereu Fontes e a toda a equipe do CECAV, formada por Benilva Paim Carvalho de Sousa, Celia Cristina de Rezende e Wanderlei Rodrigues de Souza, pelo apoio técnico e logístico, sem contar o companheirismo e amizade. Ao Parque Nacional da Serra da Bodoquena pelo apoio, através do Dir. Adilio Augusto Valadão Miranda. A Superintendência Regional do IPHAN do Mato Grosso do Sul, através da Chefe Maria Margaret Escobar Ribas pela autorização de coleta na Gruta Lago Azul.

Ao Prof. Dr. Paulo César Boggiani pelo apoio, dicas e sugestões a respeito da área de estudos e geologia da região. Ao Dr. Augusto Auler pelo apoio no envio das amostras para datação radiométrica, bem como à equipe do Department of Geology and Geophysics, University of Minnesota (EUA), através do Dr. Xianfeng Wang, pelos trabalhos realizados.

Ao Ten. Cel. Claudio Márcio Rodrigues de Jesus do CECAUEX (Brasília) pela doação dos mapas 1:100.000. Ao Ten. Cel. José Donizeti L. Teles da $5^{a}$ Divisão de Levantamento do Exército pela reprodução das fotografias aéreas.

Os estudos não seriam possíveis sem o apoio de pessoas e instituições da região: Prefeitura Municipal de Bonito (MS), através das secretarias de Turismo e Meio Ambiente; Ismael Escote, da Submundo Dive; Sr. Leonel, do Sindicato Rural de Bonito; Sr. Mario Doblack, da Pousada Muito Bonito; Sra. Almira, Edmundo e equipe do Abismo Anhumas; Sr. Modesto, do Buraco das Araras; Sr. Frederico Landre, da Fazenda Califórnia; equipe da Gruta São Miguel; pessoal da Fazenda Pitangueiras; Sr. Jorge, do Passo do Cure; pessoal da Gruta Mimoso; Sr. Eduardo Coelho, do Rio da Prata e 
Estância Mimosa; Sr. Cláudio César Carneiro, do Rio Sucuri; Sr. Vidanês responsável pela Nascente do Rio Formoso; Rio Formoso Turismo (Lagoinha); Sr. Moacir, do Rio do Peixe; Sr. Laurent Beaudet, da Baia Bonita; Boca da Onça Turismo; pessoal da Fazenda Lau de Já; pessoal da Fazenda Remanso; Moradores ao Assentamento Guaicurus; Sr. Saulo Donozete Barcelos, da Associação das Familias; Sr. Nico e Sra. Ivone pelas medições do nível d’água na Gruta Lago Azul; Sérgio das Grutas pelas dicas de cavernas e dolinas.

Pela fornecimento de mapas de cavernas agradeço Marcos Philadelphi e a Profa. Nicolleta Morachioli (Gruta Lago Azul), Gilberto Menezes (Lagoa Misteriosa), Augusto Auler (mapas e relatório do Abismo Anhumas), Grupo de Estudos Espeleológicos do Paraná (Gruta São Miguel), Leandro Dybal Bertoni (grutas Ceita-Corê, Mimoso e Pitangueiras) e ao Prof. Dr. Pedro Gnaspini (IB-USP - originais de Gnaspini et al., 1994). A Adriano Gambarini pelo apoio e fornecimento de algumas fotografias subaquáticas. A Leandro Salles (Museu Nacional) pelas discussões sobre a Nascente do Rio Formoso.

Aos colegas mergulhadores Marcos Philadelphi e Ismael Escote, pelas coletas e Leandro Dybal Bertoni e Danilo Allegrini, pelo mapeamento da Nascente do Rio Formoso. Ao colega Alexandre Albuquerque pelo empréstimo das imagens. A todos os companheiros que participaram dos trabalhos de campo e de mapeamento de cavernas Wanderlei, Leandro Canaver, Alexandre Lobo, Rogério Padial, Célia, Benilva, Cel. Francisco Minerico, Chico Bill, Murilo Valle e Edmundo da Costa Jr. Sem esta equipe o trabalho seria impossivel.

Ao Prof. Setembrino Petri e a Patricia Cristalli pelo apoio e realização de trabalho de campo conjunto nas áreas de tufas (proc. FAPESP $n^{\circ}$ 01/08049-1). A Diretora do Instituto Geológico (SMA), Dra. Sonia A. A. Nogueira pelo apoio e compreensão no periodo final deste trabalho. Aos laboratórios e seções da USP: IPEN (Ana Maria Figueiredo) - análises de urânio, LIG (Prof. Dr. Marcelo Rocha) - plotagens e utilização de softwares, Raios-X (Flávio), FRX (Paulo), MEV (Isaac), laminação e gráfica. Aos colegas Sidnei, Carlos e Rodrigo pelas dicas na utilização de softwares.

A todos os colegas da pós-graduação Hélcio, Alexandre Tomio, Alessandro, Cláudia, Rodrigo, Deise, Gaston, Milene, Lucelene, lede, Neide, Frederico, Renata, Alexandre Magno, Sibele, Artur, Veridiana e Afonso Nogueira, pela amizade e colaboração.

Um agradecimento mais do que especial à minha esposa Alethéa pelo carinho, amor e dedicação ao longos dos anos, além de apoio em diversas etapas deste trabalho. 
SUMÁRIO

AGRADECIMENTOS

SUMÁRIO

.

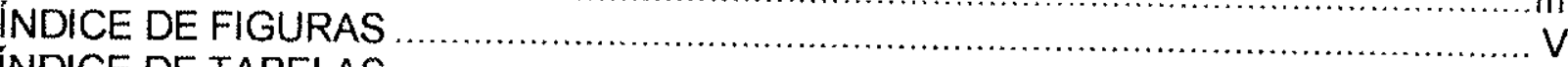

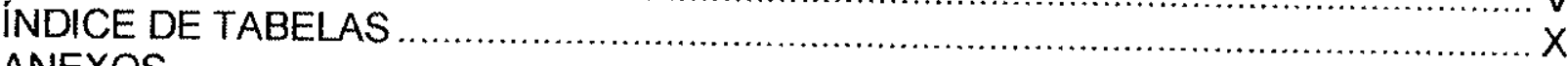

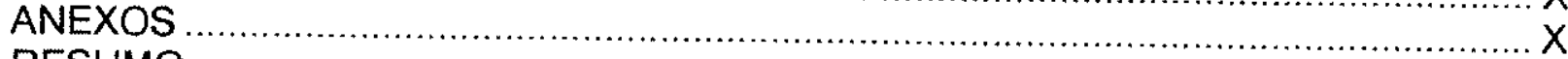

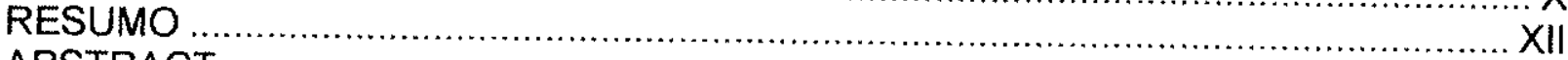

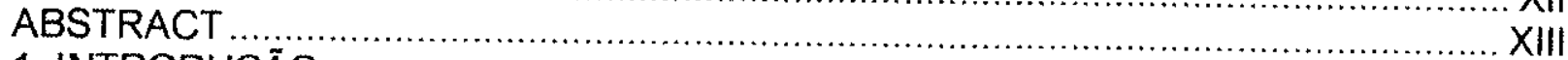

1. INTRODUÇÃO

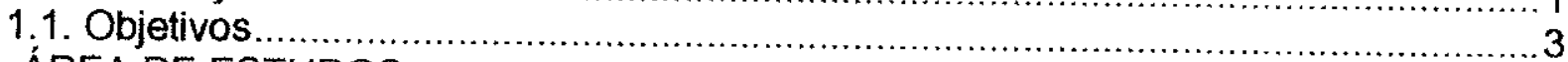

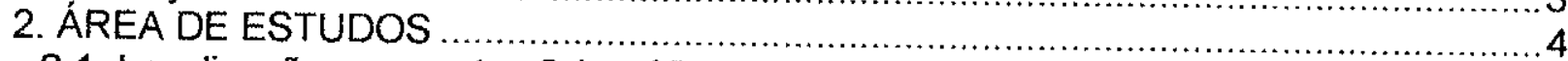

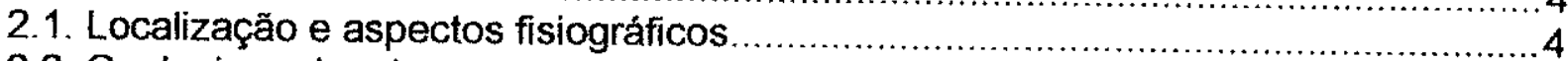

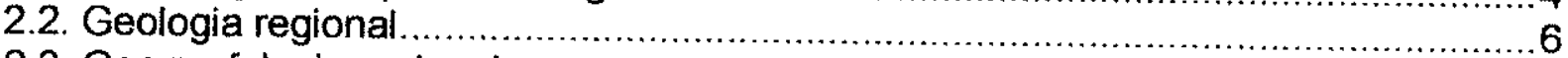

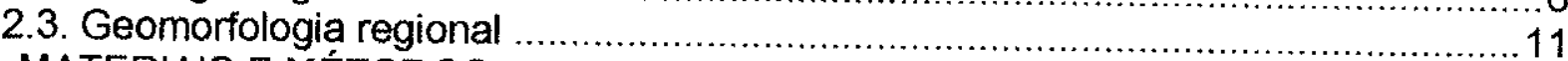

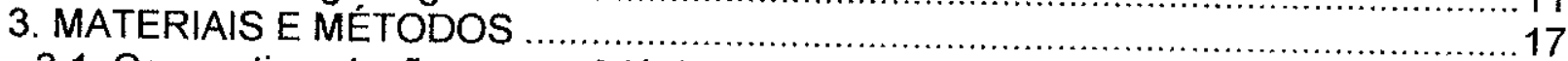

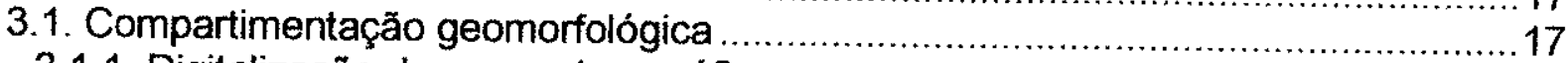

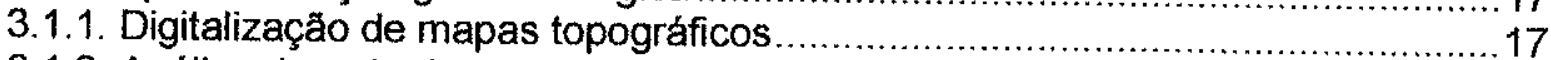

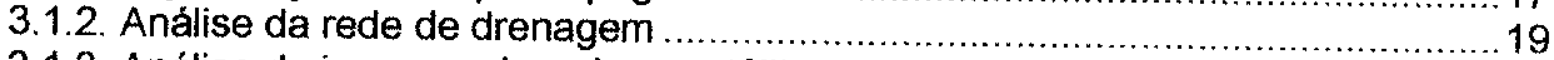

3.1.3. Análise de imagens de radar e satélite ......................................................19 19

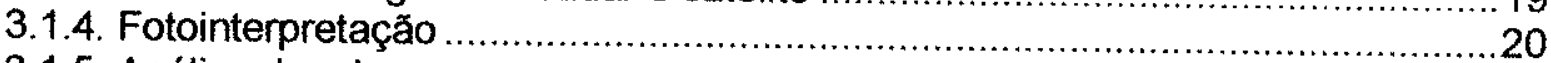

3.1.5. Análise do relevo em campo

3.1.6. Análise morfométrica do relevo

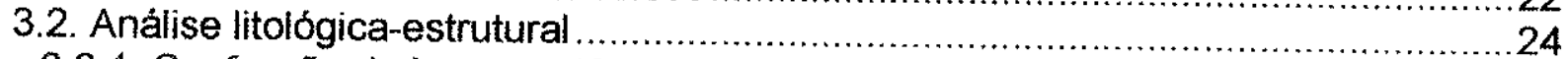

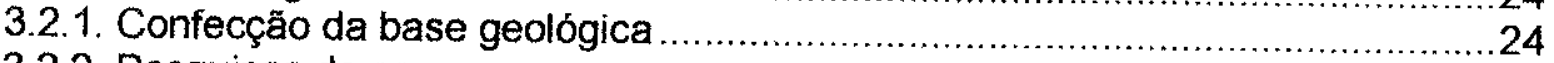

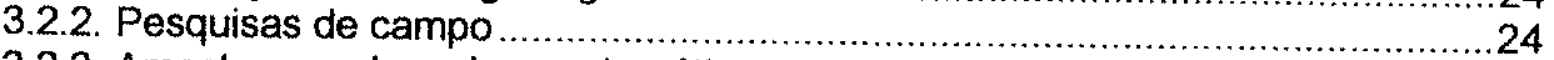

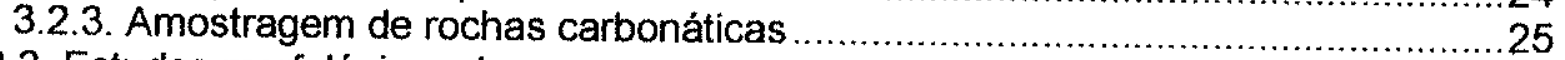

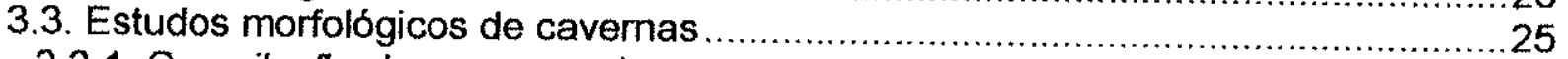

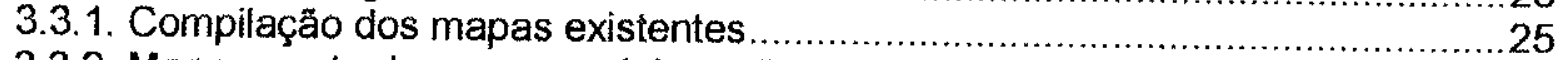

3.3.2. Mapeamento de campo e elaboraçăo de mapas das cavernas ……………....22

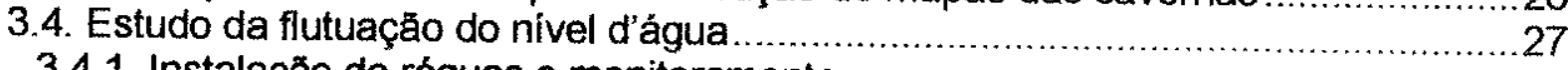

3.4.1. Instalaçåa de réguas e monitoramento ……..............................................22

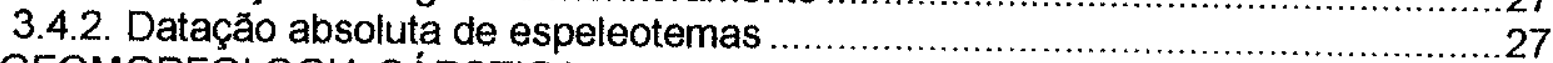

4. GEOMORFOLOGIA CÁRSTICA

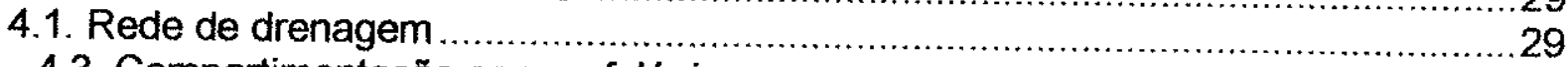

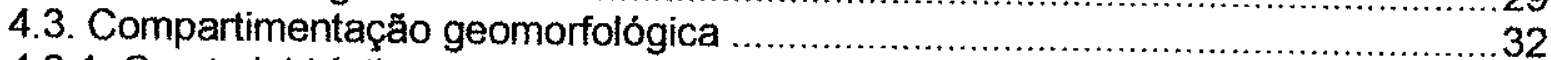

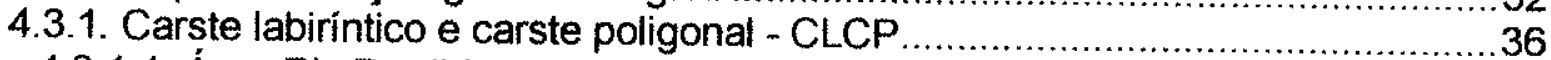

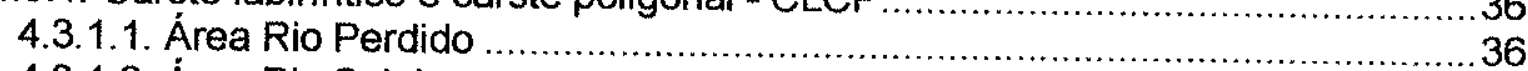

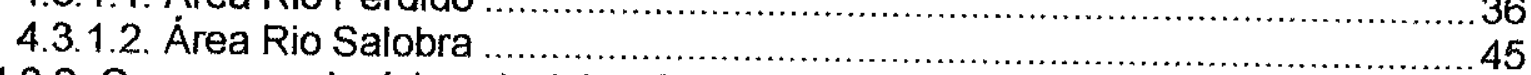

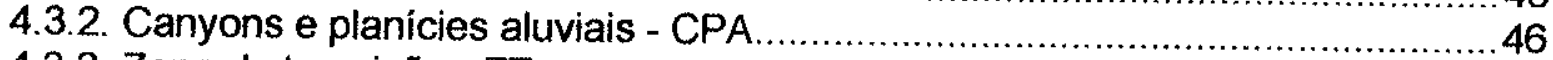

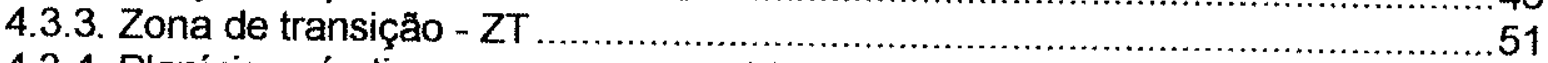

4.3.4. Planícies cársticas com morros residuais …….................................................53

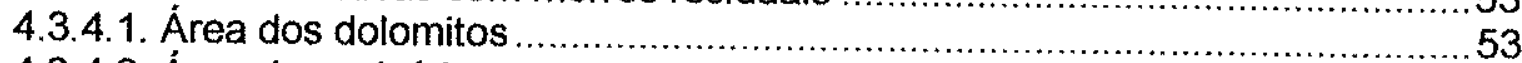

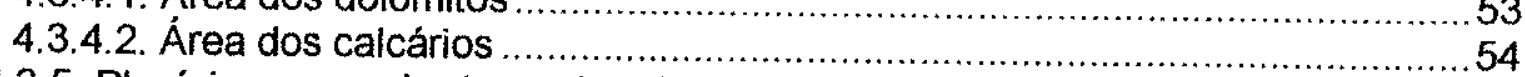

4.3.5. Planícies com coberturas de tufas - PCT ……..........................................56

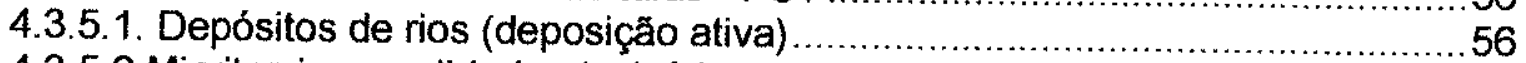

4.3.5.2. Micritas inconsolidadas (calcários pulverulentos) ………...............................5

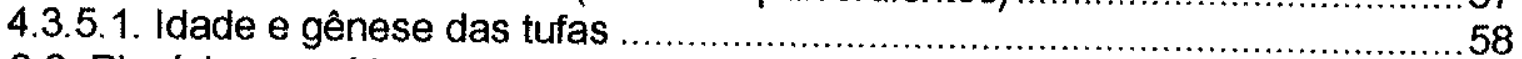

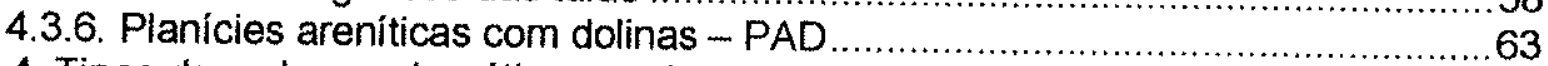

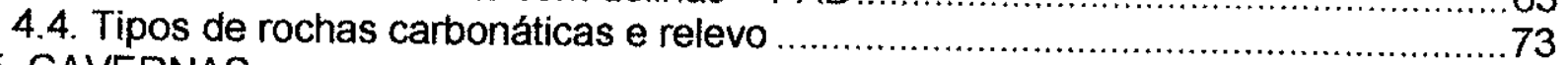

5. CAVERNAS

5.1. Trabalhos anteriores

5.2. Espeleometria 


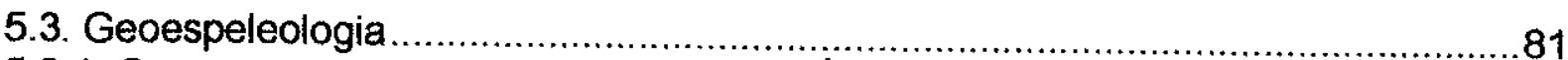

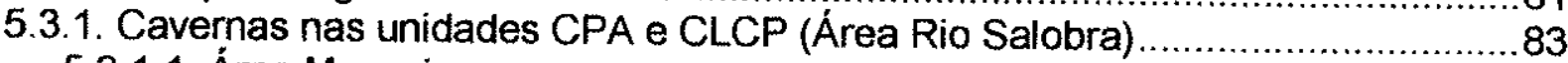

5.3.1.1. Área Morraria........................................................................ 83

5.3.2. Cavernas nas Unidade ZT e CLCP (áreas Rio Salobra e Perdido) ....................87

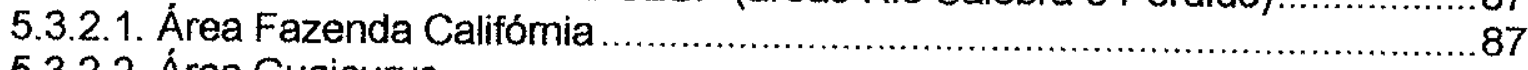

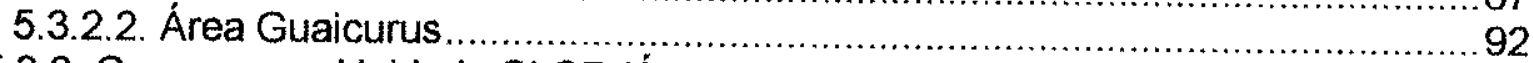

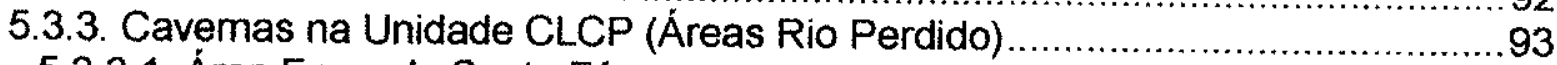

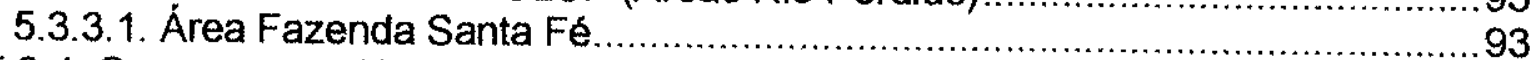

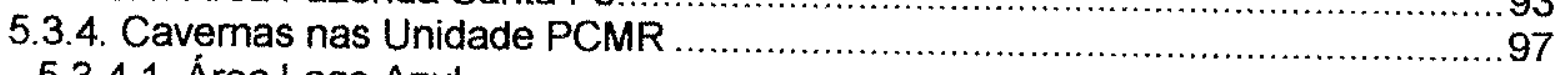

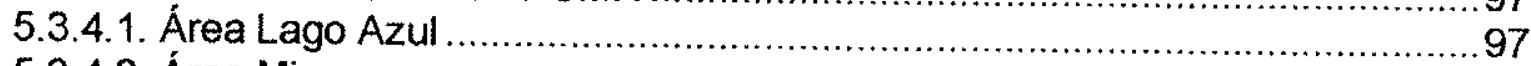

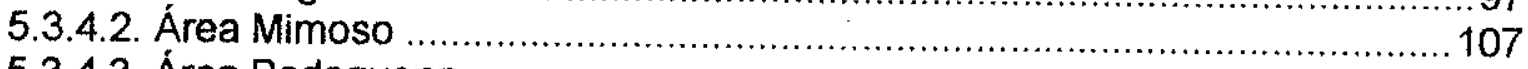

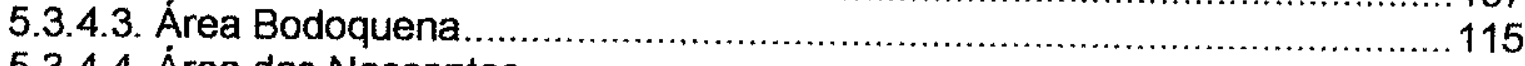

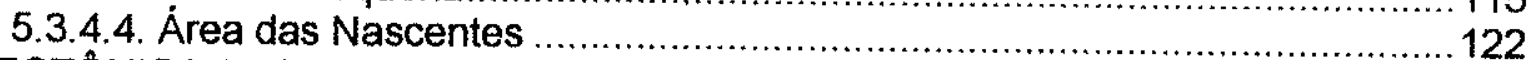

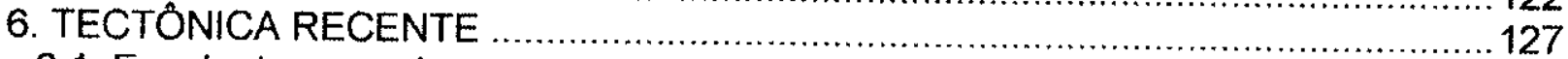

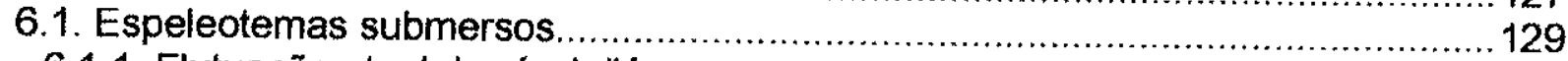

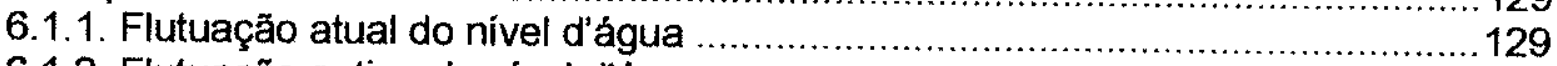

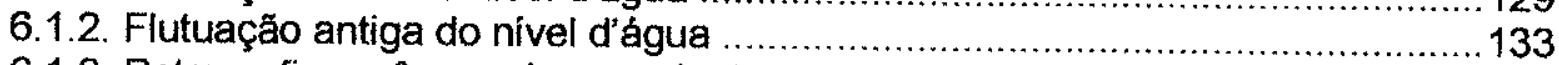

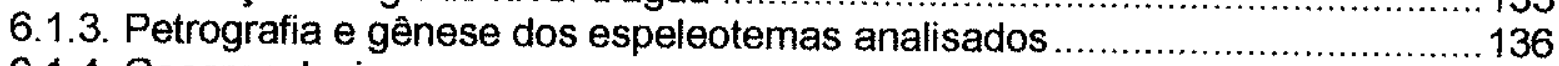

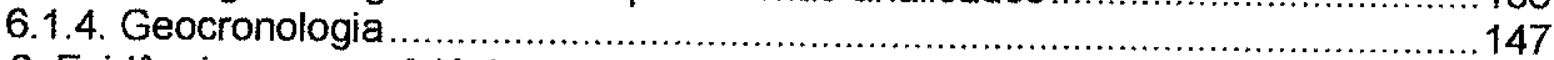

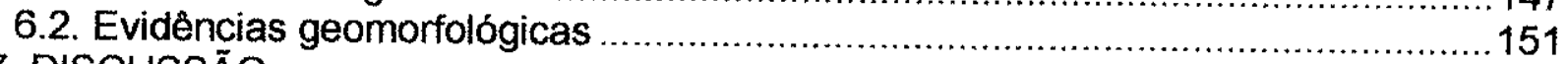

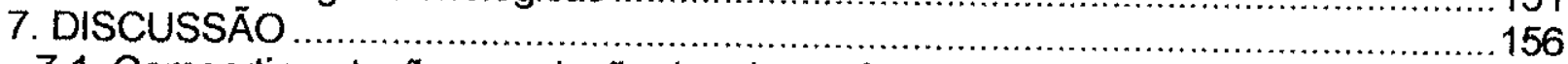

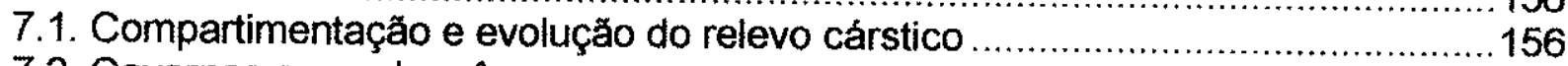

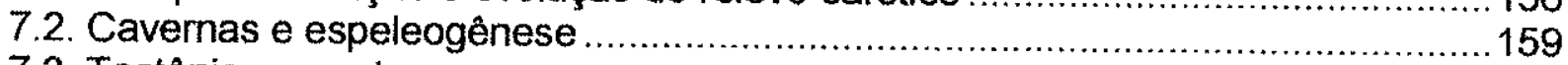

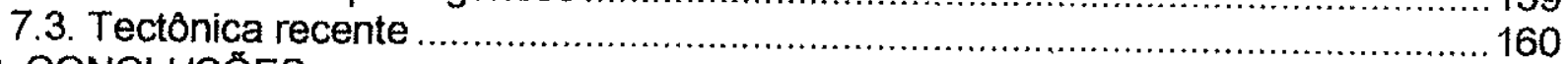

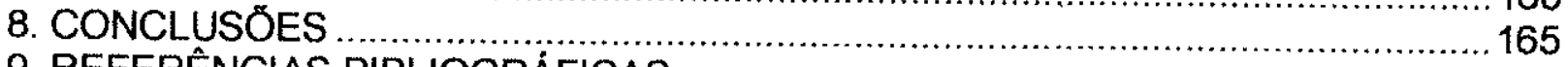

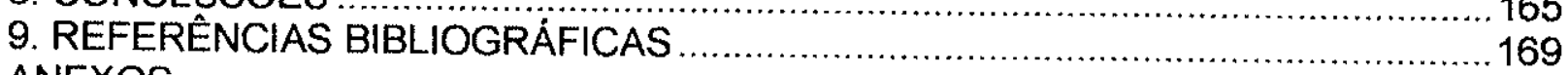

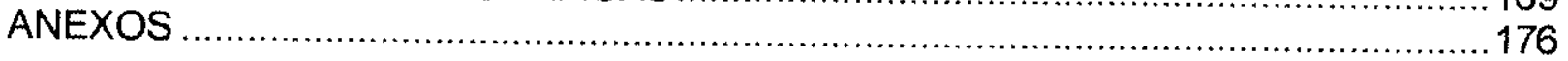


INDICE DE FIGURAS

Figura 2.1: Localização e vias de acesso da área estudada. (Adaptado de Guia de estradas Quatro Rodas, Ed. Abril, 1999)

Figura 2.2: Contexto regional da Serra da Bodoquena. A-Imagem de Radar (SRTM, 2003). Bacia do Pantanal (centro), Serra da Bodoquena (sul), Serra das Araras (norte) e Planalto de Maracaju-Campo Grande (leste); B-Geomorfologia regional, modificado de IBGE (2002); C- Geologia regional, modificado de IBGE (2002); D- Perfil geológico e topográfico esquemáticos, na seção $A-B$ localizada na Imagem $A$.

Figura 2.3: A- Mapa geológico da Faixa Paraguai e áreas adjacentes (Alvarenga, 1988); B-Mapa geológico esquemático da área de estudos (modificado de Araújo et al., 1982).

Figura 2.4: Divisão geomorfológica regional segundo Almeida (1965). I- Pantanal; IIZona Cristalina Ocidental; III- Serra da Bodoquena; IV- Zona Serrana Oriental; VDepressão Periférica do Miranda; VI- Vale do Rio Apa.

Figura 3.1: Localização da área de detalhe e das localidades principais.

Figura 3.2: Áreas de cobertura dos mapas topográficos, geológicos, fotografias aéreas, imagens de radar e satélite.

Figura 3.3: Exemplo de uma drenagem de folha topográfica (escala 1: 50.000) (A) e os pontos utilizados para a digitalização dessa drenagem para a confecção do mapa de densidade de drenagem (B)

Figura 4.1: Bacias e sub-bacias hidrográficas do Estado do Mato Grosso do Sul (Extraido de http://www2.uniderp.br/Atlas/bhidro.htm).

Figura 4.2: Direção do escoamento superficial $(A)$, bacias hidrográficas $(B)$ e densidade de drenagem (C) da Serra da Bodoquena.

Figura 4.3: A- MDT da Serra da Bodoquena obtido a partir do mapas topográficos em escala 1:100.000; B- Mapa hipsométrico obtido a partir do mapas topográficos em escala $1: 100.000 ;$ C- Principais compartimentos altimétricos e feiçőes geomorfológicas da área de detalhe.

Figura 4.4: Mapa simplificado das principais unidades morfológicas.

Figura 4.5: Feições cársticas da unidades PCCP (áreas Rio Salobra e Perdido), com respectivas rosáceas.

Figura 4.6: Imagens de satélite (LANDSAT 7): A- Norte da Serra da Bodoquena onde, a oeste, a Depressão do Rio Paraguai (embasamento granito-gnáissico-ANC) contrasta com o Planalto da Bodoquena, mais a leste, com afluentes entalhados do Rio Salobra, que nesta região compõe planicies aluviais (CPA), e interflúvios da unidade $C L C P(S)$ na área Rio Salobra e a Zona de transição (ZT); B-Contraste entre o carste poligonal dominado por cones cárstico na área Rio Perdido (CLCP.P), a oeste, e as planícies cársticas com morros residuais de dolomitos (PCMR-D), a leste; C- Carste labiríntico na porção sul do Planalto da Bodoquena (CLCP-P), com corredores de grandes dimensões.

Figura 4.7: Hipsometria com feições e modelo digital de terreno das áreas do Alto (A e

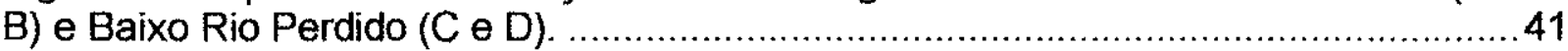

Figura 4.8: Área de detalhe no domínio CLCP (Área Rio Perdido), pontos 48 e 49 .....42

Figura 4.9: Feições observadas na Unidade CLCP na Área Rio Perdido. A- Depressão e cones do ponto 48; B-Cones alinhados no ponto 49; Vista aérea de cones na regiäo do 
Rio Perdido (C) e na Fazenda Figueira (D) (Fotos: Paulo C. Boggiani); E- Várzea nas nascente do Rio Perdido (Foto: Paulo C. Boggiani); F-Karren em epicarste com solo pouco espesso na região da Faz. Baía das Garças; G- Fenda de dissolução (abismo) próxima a Gruta da Pata.

Figura 4.10: Perfis topográficos. Escala vertical exagerada; linha pontilhada indica 730 metros de altitude; linha escura vertical indica o limite entre os calcários e dolomitos; RS- Rio Salobra; RP- Rio Perdido; 1 - Escarpa Oeste; 2 e 3- Vertentes oeste e leste do Vale do Rio Salobra; 4- Escarpa leste.

Figura 4.11: Hipsometria com feiçőes cársticas $(A)$ e modelo digital de terreno $(B)$ da unidade CLCP na área Rio Salobra, na região da Faz. Califórnia.

Figura 4.12: A- Hipsometria com feições cársticas; B-Modelo digital de terreno; CFotografia de cones cársticos da unidade CLCP na área Rio Salobra, na região de Morraria; D- Vista do Córrego Serra, mostrando o vale fechado (canyon), na Unidade CPA; E- Vertentes escarpadas do Córrego Serra onde situa-se a entrada da gruta Urubu Rei, na Unidade CPA (Ponto 19)

Figura 4.13: Hipsometria com feições cársticas (A) e modelo digital de terreno (B) na região do Assentamento Guaicurus.

Figura 4.14: Unidade CPA. A- Canyon do Rio Salobra visto a oeste a partir do ponto 142, situado na superficie aplainada da Unidade CLCP; B-Canyon de afluente do Rio Salobra, visto a norte a partir do ponto 161; Rio Salobra: C- Canyon na Faz. Boca da Onça (ponto 164), D- Vertentes escarpadas na Faz. Remanso (ponto 76), E-Planície no baixo curso, entre Morraria e Bodoquena.

Figura 4.15: Unidade ZT. A- Sumidouro da Gruta Califórnia (Ponto 9) na transição para a Unidade CLCP; B- Vista aérea de planicies na Faz. Baía das Garças (Ponto 92); CSumidouro na Faz. Baía das Garças (Ponto 92); D- Afloramento de calcário estratificado no sumidouro do Ponto 92; E- Cone cárstico isolado da Unidade CLCP, onde está situada a entrada da Gruta do Haroldo (Ponto 96). Foto B: Paulo C. Boggiani. 52

Figura 4.16: Unidade PCMR. A- Morros residuais e planicies, em vista do ponto 77 (para norte). B- Vista aérea de morros e planicies; C- Cones alinhados na região de Bonito; DSolo residual com blocos de quartzo (Ponto 53); E- Dolina em solo residual avermelhado no Ponto 119. F- Vista aérea do lago da nascente da Ceita-Corê (Ponto 130). G-Vista aérea do Rio Sucuri. Fotos B, F e G: Paulo C. Boggiani.

Figura 4.17: Tufas ativas. A- Tronco incrustado e sedimentos compostos por carapaças mineralizadas de algas caráceas (Ponto 84, Rio Formoso); B- Bioconstruções (Ponto 84, Rio Formoso); C- Amostra de bioconstrução (D) com aspecto "globular' e cor esverdeada dada pelas algas (Ponto 89, alto curso do Rio Formoso); D- Bioconstruções (Ponto 89, alto curso do Rio Formoso); E. Carapaças mineralizadas de algas caráceas e psólitos do Rio Formoso; F- Corte na amostra da fotografia C; G- Represas no Rio do Peixe (Ponto 86); H- Grande represa no Rio Mimoso (Ponto 85).

Figura 4.18: A- Depósito de tufa em terraço do Rio Mimoso (Ponto 85); B e H- Depósito de tufas antigas em Pedreira (B) no Assentamento Campina (Ponto 157), associado a planicies (H); C- Deposição ativa de tufas no leito da cachoeira do Rio Aquidaban (Ponto 90); D- Represas de tufas (intermitentes) na ressurgência da Gruta Urubu-Rei (próx. ao ponto 42); E- "Calcário Xaraiés" (Ponto 87); F e G- Concha de gastrópode e capaças de algas em tufa na pedreira no Assentamento Campina (Ponto 157). 61

Figura 4.19: Detalhe dos depósitos de tufas na região da planicie do Rio Perdido e afluentes, na unidade CLCP (calcários), no Planalto da Bodoquena. 
Figura 4.20: Distribuição de dolinas e localização das áreas detalhadas na porção sul da área de estudos (Unidade PAD). 68

Figura 4.21: A. Campo de dolinas mapeada na Área da Fazenda Santa Maria (Unidade PAD) com detalhes em imagem LANDSAT 7; B- Banda 4 em pseudocor azul

("waterlevel"); C- Composição R7G5B3 + PC1 (intensidade) 69

Figura 4.22: Dolinas da Fazenda Santa Maria (Unidade PAD) . .............................70

Figura 4.23: A- Buraco das Araras; B- Dolina do ponto 68. ........................................71

Figura 4.24: Campo de dolinas da Fazenda Chapéu de Pano (Unidade PAD) .............72

Figura 4.25: A- Representação em diagrama triangular (classificação de Leighton \& Pendexter, 1962) dos resultados analíticos de 147 amostras de rochas carbonáticas. BRelação entre $\mathrm{CaO}$ e $\mathrm{MgO}$ das 147 amostras.

Figura 5.1: Mapa de distribuição de cavernas em relação às unidades morfológicas. Numeração corresponde ao cadastro na Sociedade Brasileira de Espeleologia (SBE). 82

Figura 5.2: Mapa e seções da Gruta Urubu Rei.

Figura 5.3: A- Nivel de condutos na escarpa da margem direita do Córrego Serra. Gruta Califórnia: B- Galeria principal de seçäo retangular com pendants e condutos secundários em rede anastomosada (bases 20 e 27, Figura 5.6 perfil E-F); C. Detalhe condutos secundário com seção semi-circular demarcados por pendants (base 27); D. Protocondutos em rede anastomosada desenvolvidos em plano de acamamento. EProtocondutos em rede anastomosada desenvolvidos em plano de acamamento na Gruta do Haroldo. Gruta da Onça: F-Conduto principal com condutos laterais (à esquerda) em rede anastomosada (base 09, Figura 5.8 perfil C-D); G- Detalhe de um dos condutos secundários da rede anastomosada.

Figura 5.4: Modelo de canyon vadoso desenvolvido a partir de condutos anastomosados freáticos (Ford \& Williams, 1989) . ............................................................ 89

Figura 5.5: Mapa e seçőes da Gruta Beija Flor................................................... 90

Figura 5.6: Mapa e seçőes da Gruta Califórnia......................................................91

Figura 5.7: Mapa e seçס̃es da Gruta do Haroldo. .............................................. 94

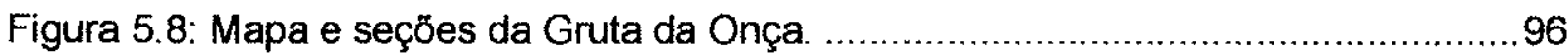

Figura 5.9: Mapas e seções das cavernas da Área Lago Azul. Mapas de: Auler et al. (2001b - Abismo Anhumas); Lino et al. (1984) e Marcos Philadelphi - Gruta Lago Azul; Lino et al. (1984 - grutas Nossa Senhora Aparecida e São Miguel); Ayub et al. (1996 Gruta do Periquito); Gnaspini et al. (1994 - Gruta do Portal).

Figura 5.10: A- Mapa geológico com MDT, perfil topográfico e geológico da Área Lago Azul, abrangendo as unidades CLCP (à oeste) e PCMR (à leste). Geologia extraida de Nogueira, V.L. \& Oliveira, C.C. (1978); B- Mapa hipsométrico com a localização, orientação e alinhamento das cavernas da Área Lago Azul. 101

Figura 5.11: Perfil topográfico ao longo do alinhamento de cavernas indicado na Figura 5.10B. Escala vertical exagerada. 102

Figura 5.12: A e B- Estereograma e rosácea de fraturas das cavernas da Área Lago Azul; C-Densidade de pólos de acamamento das cavernas da Área Lago Azul.........103

Figura 5.13: Gruta Lago Azul: A- Vista da entrada, B- Lago; C- Vista do salão do Abismo Anhumas; D- Lago no salão da Gruta Mimoso; Gruta Pitangueiras: E- Pendants em galeria lateral anastomosada; F- Conduto com ramificação em rede anastomosada. .. 104 
Figura 5.14: Gráfico da variação do nivel d'água nas grutas Lago Azul e Anhumas. ... 106 Figura 5.15: Mapas e seçőes das cavernas da Área Mimoso. Mapas de Leandro Dybal Bertoni (Gruta Mimoso) e Lino et al. (1984 - Gruta João Arruda).

Figura 5.16: Mapa e seções da Nascente da Ceita-Corê (mapa de Leandro Dybal Bertoni)

Figura 5.17: Mapas e seçōes da Gruta Pitangueiras. Mapa de Leandro Dybal Bertoni e Alexandre de Oliveira Lobo.

Figura 5.18: Rosáceas de freqüência (A) e comprimento (B) de condutos da Gruta Pitangueiras.

Figura 5.19: Mapa e seções da Gruta Cinco de Ouros.

Figura 5.20: Cavernas da Área Bodoquena. Gruta Cinco de Ouros: A- Conduto com seção circular com sedimentos na base e vulcőes sobre os sedimentos; B- Vulcões alinhados. Gruta Benedita: C- Entrada em dolina; D- Conduto eliptico paragenético, com sedimentos na base; E- Cúpula exibindo marca do nivel d'água; $F$ - Base de cúpula com depósitos de crosta subaquática.

Figura 5.21: Mapa e seções da Gruta Benedita.

Figura 5.22: Mapa e seçס̄es da Gruta Manoel Cardoso.

Figura 5.23: Mapa e seçőes da Nascente do Rio Formoso.

Figura 5.24: Croquis das nascentes do Buraco do Sapo e do Buraco das Abelhas. 126

Figura 6.1: Principais feições que indicam movimentos tectônicos recentes na área (base imagem de radar SRTM, 2003). A-Cavernas com espeleotemas vadosos submersos; B- Planalto sustentado por calcários; C- Escarpas do Planalto da Bodoquena; D- Rios entalhados; E- Estrutura linear que cruza a Serra da Bodoquena.

Figura 6.2: Totais anuais precipitados na estação pluviométrica de Bonito (MS), entre 1969 e 2003. Dados obtidos em: http://hidroweb.ana.gov.br.

Figura 6.3: A- Régua de monitoramento do nível d’água instalada no lago da Gruta Lago Azul; B- Variação do nivel d'água nas grutas Mimoso, Lago Azul e Anhumas, juntamente com dados de pluviosidade do pluviômetro no aeroporto de Bonito

(http://hidroweb.ana.gov.br).

Figura 6.4: Quadro de distribuição dos espeleotemas vadosos submersos e dos espeleotemas subaquáticos nas grutas Mimoso, Lago Azul e Anhumas, com os respectivos valores de nível d'água máximo, médio e mínimo. Os valores de nível d'água foram alinhados artificialmente pelo valor médio.

Figura 6.5: Estalactites submersas. Gruta Mimoso: A- Estalactite revestida por crosta subaquática $(-12 \mathrm{~m})$; B- Estalactites revestidas por crosta subaquática, em teto irregular, com bolhas de ar aprisionadas (aprox. $-8 \mathrm{~m}$ ); C- Provável estalactite revestida por crosta (aprox. $-20 \mathrm{~m}$ ); G- Detalhe de C; E- Estalactites revestidas por crosta subaquática, tipo "clava" (-12m), e teto sem crosta. Abismo Anhumas: F- Estalactites revestidas por crosta subaquática, tipo "clava", expostas com o nivel d'água baixo. Fotos: A e E- Ismael Escote; B a D- Marcos Philadelphi (vídeo)

Figura 6.6: Estalagmites. Gruta Mimoso: A- Estalagmites alteradas sobre blocos desmoronados $(-10 \mathrm{~m})$; B- Estalagmite revestida por crosta subaquática $(-11 \mathrm{~m})$. CAmostra de estalagmite (MI-1) coletada a -11,6 m; D- Amostra de estalagmite (MI-2) coletada a $-10 \mathrm{~m}$, exibindo bordas alteradas. Abismo Anhumas (exposto com nivel 
d'água baixo): E- Estalagmite alterada revestida por crosta; $F$ - Base de estalagmite tipo vela espessada pela cobertura de crosta; G-Detalhe de F. Fotos: A e B- Ismael Escote.

Figura 6.7: Crostas subaquáticas. Gruta Mimoso: A- Parede revestida por crostas com textura arredondada $(-19 \mathrm{~m})$; B- Salão preenchido por crostas $(-20 \mathrm{~m})$; C- "Domos" (aprox. $-20 \mathrm{~m}$ ); D e E- Crosta subaquática parcialmente descolada do teto, expondo rocha ($12 \mathrm{~m}$ ). Abismo Anhumas: F- Crostas do tipo "folhas"; G- Crostas com textura arrendada. Fotos: A- Ismael Escote; C, D e E-Marcos Philadelphi (video); B- Adriano Gambarini.

Figura 6.8: Crostas subaquáticas. Gruta Lago Azul: A-Crosta que reveste a parede na altura do nível d'água (Amostra LA-1); B- Fragmento de dolomito com veios de quartzo com revestimento de crosta (Amostra LA-2, $+2,23 \mathrm{~m}$ ). Gruta Mimoso: C-Crosta que revestia a parede (Amostra MI-7, $-15 \mathrm{~m}$ ); D- Estalagmite revestida por crosta (Amostra $\mathrm{Ml}-8,-9 \mathrm{~m})$; E- Detalhe de $\mathrm{D}$, em corte longitudinal, onde fica evidente o revestimento de crosta; F- Estalagmite revestida por crosta com textura "coralóide" (Amostra MI-9, -9m); G- Fotografia em luz transmitida de corte transversal da estalagmite de $F$, onde a crosta aparece escura na parte superior; $\mathrm{H}$ e $\mathrm{I}$ - Estalactite revestida por crosta em corte transversal em fotografia em luz refletida $(H)$ e transmitida (I). Abismo Anhumas: JCrosta com forma "coralóide" em corte transversal (Amostra AN-4, -15m).

Figura 6.9: Cones da Gruta Mimoso. A- Cones revestidos por crosta (topo -26m e base $20 \mathrm{~m})$; B- Cones alinhados; C- Cone quebrado evidenciando estrutura interna (-17m); D"Crista" em depósito de jangadas com crosta; E- Detalhe de D aonde se observa a deposição de crostas no interior oco de uma "crista"; F- Placas (jangadas) acumuladas em parede inclinada; G- Fragmento de cone exibindo placas empilhadas (Amostra MI-6, $-18 \mathrm{~m}$ ); $\mathrm{H}$ - Fragmento de cone (Foto $\mathrm{G}$ - em corte de amostra impregnada) com placas empilhadas e crosta nos espaços vazios entre as placas. Fotos: A-Ismael Escote; B a FMarcos Philadelphi (vídeo).

Figura 6.10: Cones no Abismo Anhumas. A-Cones de grandes dimensőes (base a cerca da $-26 \mathrm{~m}$ ); B-Cone pequeno exposto com o nivel d'água baixo; $\mathrm{C}$ e D-Cones (ou vulcões) em formação em pequeno lago com jangadas exposto com o nível d'água baixo; E- Jangadas depositadas em estalagmite alterada; $F$ - Piso com pequenos cones pequenos assimétricos expostos com o nível d'água baixo.

Figura 6.11: Difratogramas de raios $X$ de amostras de espeleotemas subaquáticos: $A-$ Crosta subaquática (-15 m). Amostra MI-7 (Gruta Mimoso); B-Cone subaquático (-13 $\mathrm{m})$. Amostra AN-1 (Abismo Anhumas); C- Cone subaquático (-18 m). Amostra MI-6 (Gruta Mimoso). D- Fotografia em MEV da amostra de fragmento de um cone subaquático (-18 m) (MI-06) mostrando as placas empilhadas de calcita.

Figura 6.12: Distribuição dos cones nas grutas Mimoso (A) e Anhumas (B). Representação em seções.

Figura 6.13: Espeleotemas da Gruta Mimoso, com as respectivas idades obtidas. .... 149

Figura 6.14: Vista aéreas das escarpas oeste (A) e leste (B). Fotos de Paulo C. Boggiani.

Figura 6.15: Perfis longítudinais e mapa das bacias dos rios Salobra e Perdido, com gradiente hidráulico $(G)$ por setor e razão fundo-altura de vale (Vf) de alguns pontos. 155

Figura 8.1: Modelo evolutivo do carste da Serra da Bodoquena. 168 
INDICE DE TABELAS

Tabela 4.1: Compartimentos morfológicos do carste da Serra da Bodoquena. 34

Tabela 4.2: Características gerais das dolinas mapeadas. 66

Tabela 4.3: Composições químicas das rochas carbonáticas nas unidades CLCP e PCMR.

Tabela 5.1: Dados espeleométricos das cavernas mapeadas ou com croquis da Serra da Bodoquena.

Tabela 5.2: Cavernas utilizadas na análise dos padrões morfológicos. Em cinza grutas com localização exata desconhecida.

Tabela 5.3: Medidas de acamamento na Gruta Califórnia. 89

Tabela 5.4: Medidas de fraturas na Gruta Beija Flor. 89

Tabela 5.5: Medidas de fraturas na Gruta Califórnia.. 89

Tabela 5.6: Medidas de fraturas na Gruta do Haroldo. .93

Tabela 5.7: Medidas de acamamento na Gruta da Onça. 95

Tabela 5.8: Medidas de fraturas na Gruta da Onça. .95

Tabela 5.9: Dados de direção e dimensões dos salões da área da Gruta Lago Azul. ....98 Tabela 5.10: Medidas de direção de acamamento (So) e fraturas das cavernas da área da Gruta Lago Azul. Dados extraídos de Ayub et al. (1996 - grutas Periquito e Faz. América) e de Lino et al. (1984 - grutas Lago Azul e São Miguel). .99

Tabela 5.11: Medidas de direçäo de acamamento (So) e fraturas da Gruta Mimoso. Dados desta pesquisa e de Lino et al. (1984). 108

Tabela 6.1: Listagem das amostras de espeleotemas coletados para o estudo de registro da flutuação antiga do nivel d'água.

Tabela 6.2: Resultados da análise dos teores de urânio em espeleotemas pelo método de ativação neutrônica, realizado pelo IPEN-USP.

Tabela 6.3: Idades obtidas para espeleotemas da Gruta Mimoso. 150

Tabela 6.4: Taxas de subida do nível d'água na Gruta Mimoso. 150

Tabela 6.5: Parâmetros morfométricos das bacias dos rios Perdido e Salobra. 154 
ANEXOS

Anexo 1: Capitulo de livro - SALLUN FILHO, W.; KARMANN, I.; BOGGIANI, P.C. 2004. Paisagens cársticas da Serra da Bodoquena (MS). In: MANTESSO NETO, $V$;

BARTORELLLI, A.; CARNEIRO, C.D.R.; BRITO NEVES, B.B. (EDS.) Geologia do continente Sul-Americano: evolução da obra de Fernando Flávio Marques de Almeida.

São Paulo, Beca. p. 424-433.

Anexo 3: Listagem dos mapas de cavernas obtidos. $N^{\circ}$ SBE corresponde ao número de cadastro na Sociedade Brasileira de Espeleologia (SBE). 188

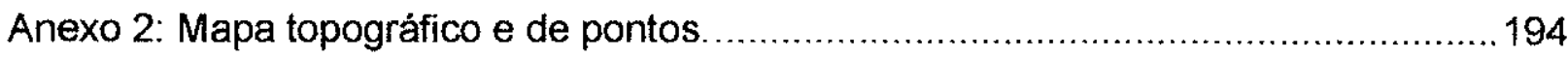

Anexo 4: Mapa geomorfológico.

Anexo 5a: Mapa geológico da área de detalhe. Compilado de Nogueira \& Oliveira, 1978; Neto et al., 1976; Araújo et al., 1982; Godoi, 2001).

Anexo 5b: Perfis geológicos e dados estruturais. Perfis compilados de Nogueira \& Oliveira, 1978; Godoi, 2001).

Anexo 6: Mapas completos das cavernas em CD-ROM (arquivos em Adobe Acrobat). 


\section{RESUMO}

A Serra da Bodoquena constitui um planalto carbonático desenvolvido nas rochas do Grupo Corumbá (Neoproterozóico III - Faixa Paraguai), que se ressalta topograficamente das planícies do estado do Mato Grosso do Sul.

A análise morfológica em escala 1:60.000 permitiu compartimentar o carste da Serra da Bodoquena em três unidades principais. A primeira corresponde a um carste de recarga mista (predominantemente autogênica) com formas de carste labiríntico e carste poligonal desenvolvidas em calcários, situada no Planalto da Bodoquena. A segunda corresponde a um carste de recarga essencialmente autogênica, com morfologia de morros residuais e planícies cársticas com dolinas, composta principalmente de dolomitos, situada na Depressão do Rio Miranda. A última consiste de um carste interestratal desenvolvido sob os arenitos da Formação Aquidauana da Bacia do Paraná, no extremo sul da Serra da Bodoquena, situada na Depressão do Rio Miranda, com a presença de dolinas em arenitos.

Apesar do sistema cárstico da Serra da Bodoquena possuir um aqüífero de condutos bem desenvolvido, evidenciado pelas nascentes cársticas, vales cegos no setor noroeste, dolinas e poços de abastecimento produtivos, as cavernas são pouco freqüentes e com pequeno desenvolvimento. Observam-se quatro padrões principais de cavernas, que ocorrem associados aos compartimentos de relevo: 1) salões de abatimento irregulares em planta e formando planos inclinados em seção longitudinal, as vezes se estendendo por até $90 \mathrm{~m}$ abaixo do nível d'água, na unidade dos morros residuais dolomíticos; 2) cavernas em rede anastomosada em planta, com condutos circulares a elípticos e ramificaçōes anastomosadas em seçäo transversal em calcários, na unidade do carste labiríntico e carste poligonal e raramente em morros residuais e planícies; 3) cavernas meandrantes em planta, as vezes associados a sumidouros ativos ou inativos, com injeção alogênica na maioria dos casos em calcários na Unidade do carste labiríntico e carste poligonal; 4) Nascentes do tipo vauclusiana nas planícies de calcários, principalmente junto a escarpa leste do Planalto da Bodoquena.

A existência de tectônica recente na Serra da Bodoquena foi constatada a partir de feições como: espeleotemas subaéreos submersos pelo menos a $16 \mathrm{~m}$ de profundidade abaixo do nivel d'água mínimo da variação sazonal; planalto escarpado sustentado por calcários e planícies por dolomitos; porção norte do planalto com rios mais entalhados que o sul; estrutura linear relacionada à borda do Pantanal, que cruza a Serra da Bodoquena, observada em escala 1:250.000. 


\section{ABSTRACT}

The Bodoquena plateau, developed over the Corumbá Group (Neoproterozoic III - Paraguai Fold Belt), is a carbonate rock highland relative to the non carbonate lowlands of the Mato Grosso do Sul State, mid-western Brazil.

Based on 1:60.000 scale morphological analysis of the karst topography, three main compartments were defined. The first one is a mixed recharge karst system (mainly autogenic), dominated by labyrinth and polygonal karst landforms, developed over limestone of the Bodoquena plateau. The second unit is characterized by essentially autogenic recharge, residual hills and karstic plains with dolines, developed mainly over dolomites of the Miranda river depression (lowlands). The third one, characterizes an interestratal karst system in proterozoic limestones overlain by sandstones of the Aquidauana Formation of the phanerozoic Paraná basin. This geomorphological unit is localized at the southern extremity of the Bodoquena plateau, exhibiting flat topography, with frequent dolines in sandstone, of up to $700 \mathrm{~m}$ in diameter.

Although the Bodoquena karst system is well developed, as can be inferred based on the presence of several vauclusian springs, blind valleys in the northwest border, dolines and a deep conduit aquifer evidenced through productive water wells, the cave incidence is low as are their dimensions, considering the large carbonate rock exposure. Four cave patterns were recognized, which are related to the above geomorhological units: 1) large irregular breakdown halls in plan view and dipping planes in longitudinal section (following bedding and joint surfaces), which frequently reach up to $90 \mathrm{~m}$ beneath the water table, sometimes with large lakes, as for example, the Lago Azul cave (Bonito municipality). This pattern is the most frequent cave type of the second unit, occurring at the dolomitic residual hills with karst plains; 2) network caves with anastomotic pattern in plan view and circular to elliptical conduits with lateral anastomosis in cross section. They occur mostly associated with the labyrinth and polygonal karst topography of the first morphological unit and rarely with the unit of residual hills and plains; 3) caves with meandering conduits in plan view, sometimes with active or inactive allogenic stream sinks, associated with the polygonal and labyrinth karst topography; 4) Steep dipping phreatic conduits, characterizing vauclusian springs, occurring at the limestone plain along the base of the eastern escarpment of the Bodoquena plateau.

The recent tectonic activity along the Bodoquena plateau area was detected by the following features: vadose speleothems submerged at least $16 \mathrm{~m}$ beneath the lowest seasonal water level stage; limestone highland with escarpment beside dolomitic lowlands; northern part of the carbonate plateau with deep entrenched river valleys in contrast with the southern sector of open valleys and less entrenchment; linear structure observed in 1:250.000 scale which marks the border of the Pantanal basin and crosses the Bodoquena plateau. 


\section{INTRODUÇÃO}

A Serra da Bodoquena possui um importante sistema cárstico que chama a atenção devido as suas características distintas e peculiares, em comparação com as outras áreas cársticas do Brasil. Apesar da importância dessa região, até o momento poucos estudos especificos em geologia do carste foram nela desenvolvidos.

A Serra da Bodoquena consiste de um planalto e de planícies predominantemente carbonáticas do Grupo Corumbá (Neoproterozóico III) juntamente com as planícies de natureza terrígena e carbonática do Grupo Cuiabá, todos da Faixa Paraguai (Almeida et al., 1976). Ao norte as rochas carbonáticas são recobertas por sedimentos cenozóicos da Formação Pantanal e ao sul apresentam continuidade até o Paraguai, onde são descritas como Grupo Itapucumi.

No contexto geomorfológico da região oeste do Brasil, a Serra da Bodoquena é uma feição marcante, pois constitui um planalto carbonático que se destaca das planícies do Pantanal Matogrossense. A predominância de exposições carbonáticas do Grupo Corumbá em área relativamente extensa, proporcionou o desenvolvimento de relevo cárstico e intensa formação de tufas calcárias ao longo da drenagem atual, reunidos por Karmann \& Sánchez $(1979,1986)$ na Província Espeleológica da Serra da Bodoquena. Situada na região sudoeste do Estado de Mato Grosso do Sul é tradicionalmente conhecida pela pequena incidência de cavernas, na maioria com dimensões reduzidas, apesar da grande área carbonática e condições básicas favoráveis para o desenvolvimento da espeleogênese.

Após a primeira citação da presença de carste e cavernas na região por Mendes (1957), Almeida (1965) fez a primeira (e única até o momento) caracterização mais completa do carste em seu trabalho "Geologia da Serra da Bodoquena", onde ressalta a necessidade de estudos geomorfológicos da regiäo no sentido de definir suas unidades geomórficas, o que permitiria a interpretação da origem e evolução das grandes formas de relevo que compõem o oeste do Mato Grosso do Sul, mas descreveu um sistema cárstico pouco desenvolvido. A presente pesquisa vem de encontro à recomendação de Almeida (1965) que até o momento foi muito pouco desenvolvida, preenchendo assim, uma lacuna no conhecimento geológico e geomorfológico do carste da Serra da Bodoquena. Neste estudo revelou-se a existência de um sistema cárstico bem desenvolvido, porém com poucas cavernas.

Os poucos trabalhos que existem sobre do carste da Serra da Bodoquena (Lino et al., 1984; Auler, 1991; Auler, 1992; Auler \& Boller, 1992; Gnaspini et al., 1994; Ayub et al., 1996), foram realizados com um intuito do seu manejo turístico, para exploração e 
espeleo-mergulho. Estes trabalhos também incluem a topografia de algumas cavernas, incluindo as que apresentam desenvolvimento submerso, realizados por diversas entidades. Quanto aos aspectos da fauna das cavernas da região alguns trabalhos já foram realizados (Godoy, 1986) e ainda estão em andamento, coordenados por pesquisadores do Instituto de Biociências da USP. Porém a geologia do carste da Serra da Bodoquena foi muito pouco discutida, apenas sendo ligeiramente abordada em Lino et al. (1984) e em Ayub et al. (1996).

O carste no Brasil representa cerca de $2 \%$ do território brasileiro e por ser uma das mais extensas áreas carbonáticas contínuas do Brasil, com cerca de $7000 \mathrm{~km}^{2}$ (Auler et al., 2001a) e com poucos estudos, um detalhamento era necessário. Além disso, os aspectos pelos quais a Serra da Bodoquena se distingue das demais áreas cársticas no Brasil, geraram interesse científico para o presente estudo, tais como: 1) Situa-se em uma área com tectônica recente ativa comprovada, dentro do contexto da Plataforma Brasileira (Riccomini \& Assumpção, 1999); 2) Trata-se de uma área carbonática elevada em relação às rochas insolúveis adjacentes, apesar de condições climáticas recentes úmidas a sub-úmidas; 3) As rochas carbonáticas exibem compartimentos com elevação contrária ao esperado, com áreas de calcários elevados em relação a áreas dolomíticas deprimidas; 4) Apesar da grande área carbonática (calcários e dolomitos), a região possui poucas e pequenas cavernas; 5) É o único sítio conhecido com expressiva deposição atual de tufas calcárias no Brasil; 6) A ocorrência de espeleotemas vadosos abaixo do nivel d'água, cuja submersão pode ser relacionada a fatores tectônicos e/ou climáticos, representa uma das principais polêmicas científicas da área.

A importância do Patrimônio Espeleológico da Serra da Bodoquena foi reconhecida em 1978, quando duas dentre suas dezenas de cavernas (grutas Lago Azul e Nossa Senhora Aparecida) foram tombadas pelo Instituto do Patrimônio Histórico e Artístico Nacional - IPHAN (processo $n^{0}$ 79-T-1978). Mais recentemente foi reconhecida como patrimônio natural, tanto a nivel nacional quanto internacional, através de sua declaração juntamente com o Pantanal, como Patrimônio da Humanidade e Reserva da Biosfera, e a criação do "Parque Nacional da Serra da Bodoquena" (Decreto Presidencial de 21 de setembro de 2000). Além disso, integra a lista de sítios geológicos e paleobiológicos que compõem Patrimônio da Humanidade, através das tufas calcárias (Boggiani et al., 2000) e da Gruta do Lago Azul.

Do ponto de vista econômico esta região apresenta um turismo crescente nos últimos anos. Atualmente, o municipio de Bonito recebe por volta de 71.000 turistas por ano, segundo dados da Secretaria Municipal de Turismo e Meio Ambiente, e possui 
2.914 leitos distribuídos em 731 apartamentos de 57 estabelecimentos hoteleiros (pousadas e hotéis), segundo a Associação Bonitense de Hotelaria (Lunas, 2000). Além desta estrutura formal, deve ser contabilizada a significativa estrutura informal de aluguel de casas e quartos em residências, o que demonstra o aumento considerável da atividade turística da região, onde as principais atividades econômicas são a pecuária e a agricultura, seguidas da exploração mineral e vegetal. As regiões cársticas apresentam alta vulnerabilidade à contaminação do aqüifero cárstico, relacionada a condicionantes geológicos e às formas de uso e ocupação do solo, além da ocorrência de risco geológico como colapsos (dolinamentos) descrito na Serra da Bodoquena. Dessa forma, este estudo fornece um primeiro esboço de áreas menos favoráveis a ocupação do solo, frente à crescente exploração turística e instalação hoteleira, que em sua maioria é abastecida por água subterrânea do aqǘfero cárstico.

\subsection{Objetivos}

A presente tese tem como meta geral caracterizar e compreender o carste da Serra da Bodoquena e inserir sua evolução no contexto geológico do Cenozóico. Neste quadro, a pesquisa tem os seguintes objetivos especificos:

- Compartimentar o relevo cárstico da região da Serra da Bodoquena com base nas formas de relevo e na morfometria;

- Estabelecer os padrões de cavernas existentes na região;

- Avaliar os condicionantes geológicos dos diferentes tipos de relevo e padrões de cavernas analisados;

- Obter idades de espeleotemas submersos e subaquáticos, e relacionar a variação do nivel d'água com o processo de subsidência da região;

- Propor um modelo evolutivo preliminar para o carste na região.

Deste modo, o objetivo deste estudo é atingir os meios técnico-científicos, principalmente quanto à evolução cenozóica desta área, além de apresentar resultados que sirvam de subsidio para um melhor planejamento ambiental tanto em aspectos do uso e ocupação do solo quanto na orientação do aproveitamento do turístico na região, inclusive do Plano de Manejo do Parque Nacional da Serra da Bodoquena, que deverá ser elaborado até o ano 2005, segundo decreto de criação do parque. 


\section{2. ÁREA DE ESTUDOS}

\subsection{Localização e aspectos fisiográficos}

A Serra da Bodoquena pertence a um conjunto de planaltos que circundam a bacia do Pantanal Matogrossense. Estende-se por cerca de $220 \mathrm{~km}$ na direção norte-sul, com até $40 \mathrm{~km}$ de largura e altitudes de até $800 \mathrm{~m}$. Encontra-se inserida no estado do Mato Grosso do Sul, situada a sudeste da Planície do Pantanal, com cerca de $7000 \mathrm{~km}^{2}$, abrangendo partes dos municípios de Porto Murtinho, Caracol, Bela Vista, Jardim, Bonito, Bodoquena, Miranda e Corumbá. Está situada entre $19^{\circ} 45^{\prime}$ e $22^{\circ} 15^{\prime}$ de latitude sul e entre $57^{\circ} 30^{\prime}$ e $56^{\circ} 15^{\prime}$ de longitude oeste, conforme ilustrado na Figura 2.1

Alguns aspectos foram analisados na serra como um todo, mas os estudos se concentraram em uma área de detalhe na porção central da serra. Os critérios para delimitação desta área serão discutidos no item 3.

A Serra da Bodoquena possui clima tropical sub-quente e úmido, com temperaturas médias entre 15 e $18^{\circ} \mathrm{C}$, com pluviosidade média de $1250 \mathrm{~mm}$ anuais com 1 a 3 meses secos (Nimer, 1979) no período de junho a agosto. A cobertura vegetal é de savanas e floresta estacional decidual.

A cidade de Bonito dista $320 \mathrm{~km}$ da capital do estado, Campo Grande, e cerca de $1300 \mathrm{~km}$ da cidade de São Paulo. O acesso mais curto a partir de São Paulo é por Maracaju - Guia Lopes, através de estradas asfaltadas. De Guia Lopes até Bonito utiliza-se a MS-382, percorrendo um trecho de $64 \mathrm{~km}$. 


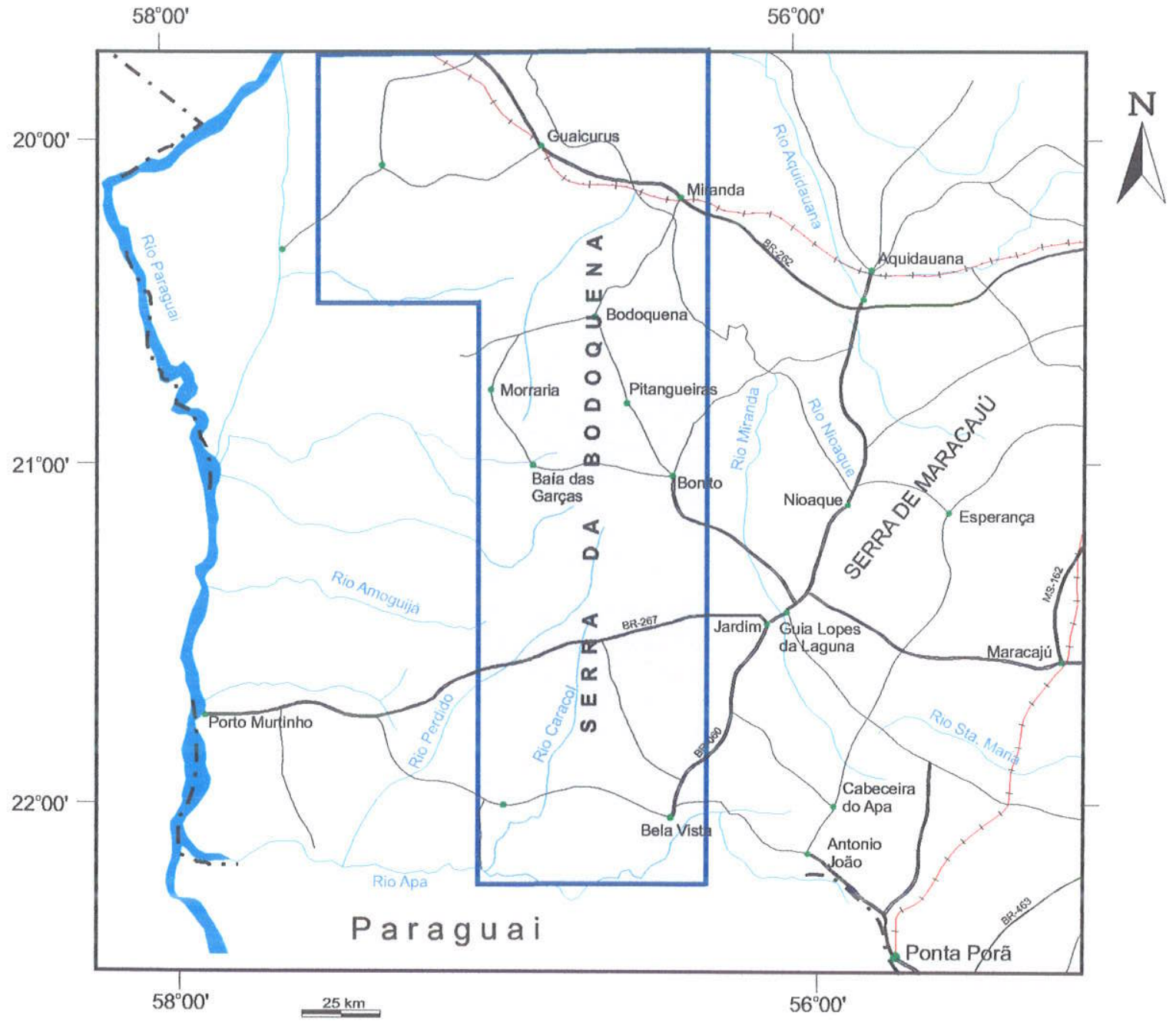

\section{LEGENDA}
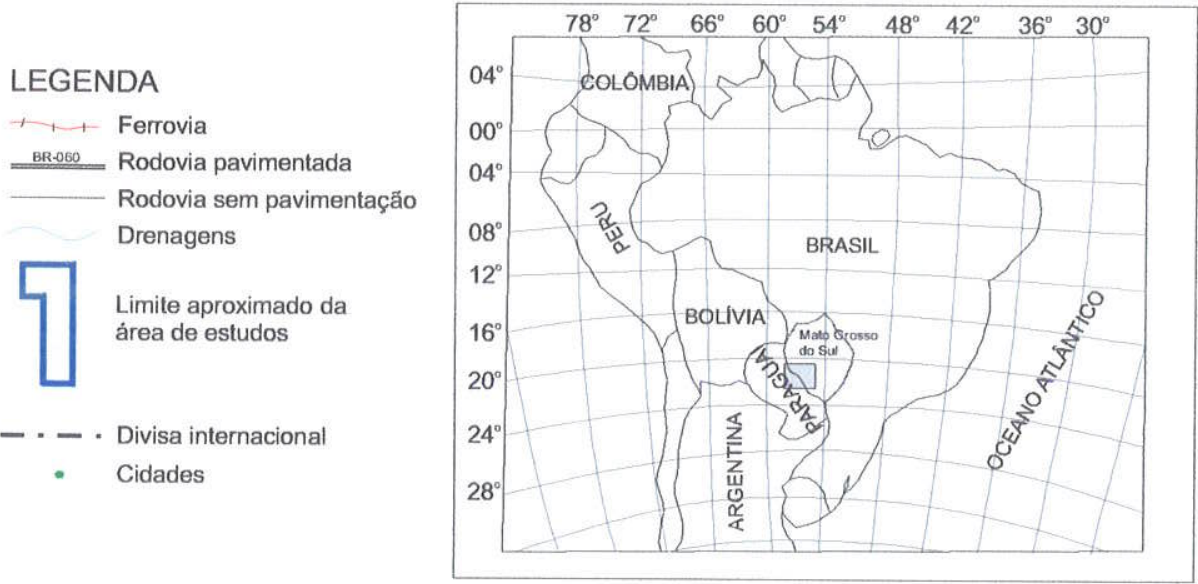

Figura 2.1: Localização e vias de acesso da área estudada. (Adaptado de Guia de estradas Quatro Rodas, Ed. Abril, 1999). 


\subsection{Geologia regional}

O carste da Serra da Bodoquena desenvolve-se sobre as rochas do Grupo Corumbá, unidade neoproterozóica pertencente a Faixa de Dobramentos Paraguai (Figuras 2.2 e 2.3). O Grupo Corumbá assenta-se discordantemente sobre rochas do Complexo Rio Apa, que é composto de gnaisses, migmatitos, granitos, xistos e anfibolitos de mais de 1,7 Ba (Figura 2.3) (Araújo et al., 1982).

Segundo Boggiani et al. (1993), a Faixa de Dobramentos Paraguai que comporta principalmente o Grupo Corumbá e correlatos, é uma faixa que contorna o Cráton Amazônico de forma descontínua e curva, convexa para noroeste, que se estende por $2500 \mathrm{~km}$, desde o Paraguai (Grupo Itapucumi) ao Brasil, por onde passa pela Serra da Bodoquena e Corumbá, no estado do Mato Grosso do Sul, flexionando-se para N-NE na Serra das Araras, no estado do Mato Grosso (Figura 2.2). Na região ao norte de Corumbá dispõe-se uma faixa carbonática (Grupo Murciélago) de direção E-W, que adentra na Bolívia, no Cráton Amazônico (Figura 2.2).

Na Faixa Paraguai é possivel distinguir três unidades principais aflorantes: uma unidade inferior (Grupo Cuiabá, MS e MT), caracterizada por metassedimentos predominantemente peliticos de caráter turbiditico; uma unidade intermediária carbonática (Grupo Corumbá, MS e Formação Araras, MT), que localmente recobre sedimentos glácio-marinhos (Formação Puga); uma unidade superior, representada por arenitos e folhelhos continentais (Grupo Alto Paraguai, MT) (Boggiani, 1998). O Grupo Corumbá, de aproximadamente $700 \mathrm{~m}$ de espessura inicia-se com conglomerados, arenitos e pelitos da Formação Cadiuéus que gradam para arenitos, pelitos e carbonatos da Formação Cerradinho. Estes, por sua vez, passam para dolomitos da Formação Bocaina, que é recoberta pelos calcários e folhelhos carbonosos da Formação Tamengo (Anexo 5a). O grupo termina com espesso pacote pelítico (Formação Guaicurus) (Boggiani, 1998). 
A
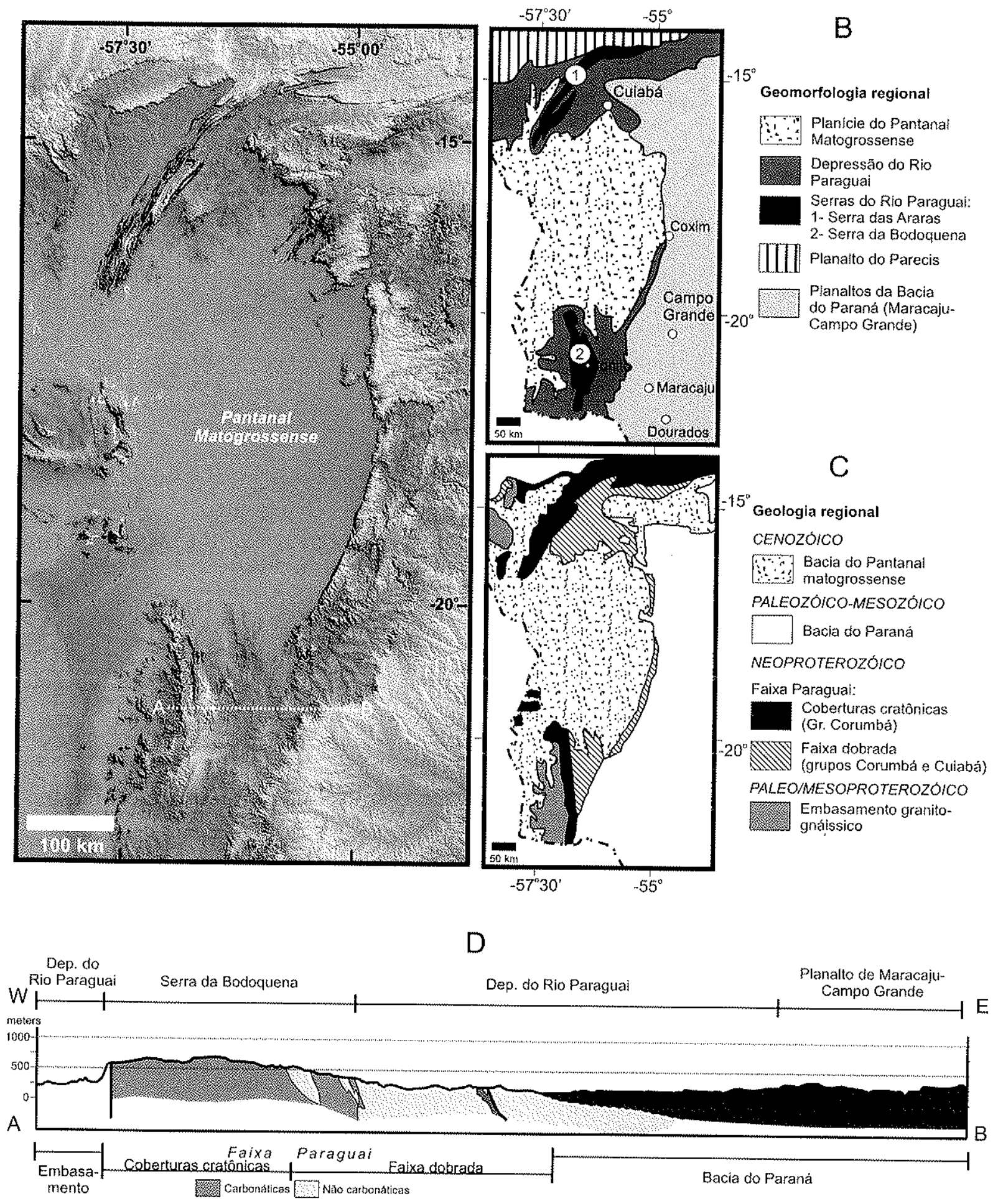

Figura 2.2: Contexto regional da Serra da Bodoquena. A- Imagem de Radar (SRTM, 2003). Bacia do Pantanal (centro), Serra da Bodoquena (sul), Serra das Araras (norte) e Planalto de Maracaju-Campo Grande (leste); B- Geomorfologia regional, modificado de IBGE (2002); C- Geologia regional, modificado de IBGE (2002); D- Perfil geológico e topográfico esquemáticos, na seção A-B localizada na Imagem A. 


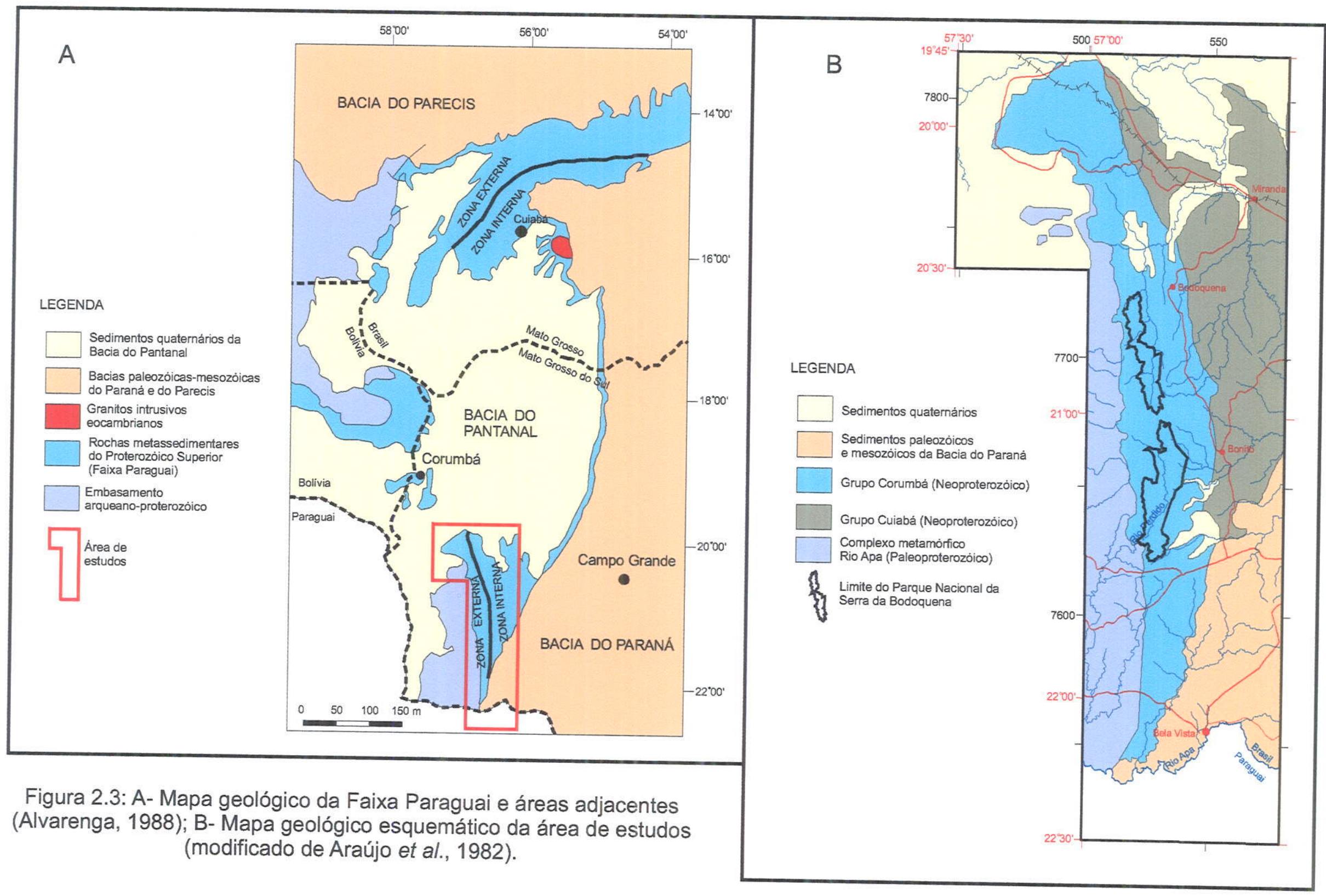


Alvarenga \& Trompette $(1993,1994)$ estudaram a Faixa Paraguai no estado de Mato Grosso, e demonstram que a faixa apresenta três porções distintas, dispostas paralelamente, com maiores niveis de deformação e metamorfismo conforme o afastamento do cráton se adentra na faixa. São elas: Domínio cratônico - ondulações suaves e tectônica rúptil (falhas normais); Zona externa - dobras abertas cortadas por falhas inversas, localmente afetadas por um metamorfismo muito fraco; Zona interna dobras abertas, inversas e isoclinais, com metamorfismo de baixo grau (Figura 2.2). Segundo os autores acima, o contato entre o domínio cratônico e a zona externa não é observado, pois se encontra encoberto por sedimentos cenozóicos, enquanto o contato entre as zonas externa e interna é feito por falhas inversas de alto ângulo.

Na região estudada por Alvarenga \& Trompette (1993, 1994, Serra das Araras, MT) - domínio cratônico engloba rochas das formações Puga, Araras, Raizama e Diamantino; a zona externa rochas das formações Bauxi, Puga, Araras, Raizama e Diamantino e na zona interna essencialmente as rochas do Grupo Cuiabá. Já na Serra da Bodoquena, tanto o domínio cratônico quanto a zona externa englobam rochas do Grupo Corumbá, enquanto a zona interna está representada por rochas do Grupo Cuiabá.

A estruturação do Grupo Corumbá remete-se ao início do Cambriano, quando foi submetida a uma deformação associada a baixo grau metamórfico. As estruturas principais (dobras e falhas) seguem uma tendência geral norte-sul, sendo divididas em duas porções principais: uma a oeste menos deformada, que são as coberturas cratônicas, e outra a leste, mais deformada, que corresponde à Faixa Paraguai (Figura 2.2). Na região oeste ocorre dobras abertas com eixos norte-sul e a leste dobras mais fechadas a isoclinais, com falhas de empurrão com vergência para oeste (Figura 2.2).

Na Serra da Bodoquena Araújo et al. (1982) reconhecem no Grupo Cuiabá direções de foliação NE-SW com mergulhos para SE. No Grupo Corumbá os autores descrevem camadas dobradas acentuadamente, mais próximo à faixa, com mergulhos de até $50^{\circ}$ para NE e SE, e dobras suaves, com mergulhos para NE e NW na porção cratônica. Estas dobras possuem eixos de direção geral NNE-SSW (Araújo et al., 1982). As estruturas rúpteis também são muito comuns, na forma de falhas inversas, transcorrentes, normais e fraturas. O Grupo Corumbá, segundo Araújo et al. (1982), apresenta uma direção principal das falhas para NW e das fraturas para NE. Estas estruturas rúpteis são bem evidenciadas nos carbonatos da Formação Bocaina, em fotografias aéreas (1:60.000). 
O ambiente de sedimentação do Grupo Corumbá é tipicamente de uma plataforma continental, aberta para leste, onde foram depositados os sedimentos de águas mais profundas (Boggiani et al., 1993).

A idade do Grupo Corumbá é estimada, com base em diversas evidências estratigráficas, geocronológicas e paleontológicas, como sendo do Proterozóico terminal, ou até alcançando o Cambriano. A Formação Puga, inferior ao Grupo Corumbá, evidencia, segundo Alvarenga \& Trompette (1992), a última grande glaciação do Proterozóico, a Glaciação Varangeriana, que teria terminado em torno de $600 \mathrm{Ma}$, idade coerente com dados de isótopos estáveis obtidos por Zaine (1991) nos carbonatos do Grupo Corumbá. A comparação do conteúdo paleontológico e dos isótopos de $\mathrm{C}, \mathrm{O}$ e Sr com os do Grupo Nama, na Namíbia, levou Boggiani (1998) a interpretar a idade da sedimentação da Formação Tamengo em 548 a 544 Ma, justamente no limite inferior do Cambriano. A presença de Cloudina lucianoi, Bavlinella e Tyrasotaenia na Formação Tamengo (Zaine, 1991), é coerente com uma idade vendiana terminal. A única análise radiométrica disponivel para o Grupo Corumbá indicou uma idade de $489 \pm 29$ Ma para eventos termodinâmicos tardios do Ciclo Brasiliano ( $\mathrm{Rb}-\mathrm{Sr}$, rocha total em siltitos da região de Corumbá; Cordani et al., 1985). A idade de sedimentação do Grupo Cuiabá deve ser muito próxima a do Grupo Corumbá, só que formado em águas mais profundas, e posteriormente mais deformado, por estar na zona central da faixa (Boggiani et al., 1993). Estas duas unidades foram denominadas com nomes diferentes por causa da variação na deformação, que era considerado por certos autores como critério para estabelecer idades, e dentro deste contexto, o Grupo Cuiabá era considerado mais antigo, segundo alguns autores como Araújo et al. (1982).

Sob o ponto de vista paleontológico, o Grupo Corumbá é uma unidade muito importante, pois possui um rico e diversificado conteúdo fossilifero, como descrito por Zaine \& Fairchild (1987) e Zaine (1991) e mais recentemente por Fairchild et al. (1999), observado principalmente na região de Corumbá (MS), na Serra da Bodoquena e na Província Serrana.

A Faixa Paraguai na Serra da Bodoquena encontra-se em sua porção sudeste encoberta por rochas sedimentares paleozóicas e mesozóicas da Bacia do Paraná, especialmente por arenitos da Formação Aquidauana (Grupo Tubarão) (Figura 2.3).

Já na sua porção norte encontra-se encoberta por sedimentos cenozóicos Bacia do Pantanal (Pantanal Matogrossense) (Figuras 2.2 e 2.3). Esta bacia é preenchida por sedimentos oriundos da erosão dos planaltos circunvizinhos conduzidos pela rede de rios da bacia hidrográfica do Alto Paraguai (Shiraiwa, 1994). A região do Pantanal 
Matogrossense é composta segundo Araújo et al. (1982) por sedimentos pleistocênicos, arenosos, argilosos e siltosos, inconsolidados. A partir de dados gravimétricos, Shiraiwa (1994) concluiu que a origem da Bacia do Pantanal se deve a uma subsidência em resposta à carga dos Andes Centrais, que causaram a reativação das falhas da Faixa Paraguai, na transição do Plioceno/Pleistoceno. Dentro do modelo de Shiraiwa (1994), antes da subsidência houve um soerguimento regional, que elevou as altitudes até cerca de $1000 \mathrm{~m}$, o que explica a topografia elevada das regiões que circundam a bacia. Dentro deste contexto a Serra da Bodoquena representa um vestígio deste soerguimento que circunda atualmente o Pantanal. A espessura de sedimentos na Bacia do Pantanal foi determinada através de perfurações realizadas pela PETROBRÁS e por alguns poços de água subterrânea, alcançando uma profundidade máxima de 412,5 m sendo que a base do pacote sedimentar não foi alcançada (Weyler, 1962, 1964 apud Shiraiwa, 1994). A subsidência da Bacia do Pantanal é um processo que ainda está ocorrendo, com evidências de neotectônica como falhas e fraturas descritas por Gesicki \& Riccomini (1998).

Também ocorrem na região da Serra da Bodoquena calcários quaternários, descritos por Boggiani \& Coimbra (1995) em três grupos principais: calcário Xaraiés, calcários do Pantanal do Miranda e tufas da Serra da Bodoquena. Estes calcários possuem ambientes de formação distintos entre si, mas com uma área fonte em comum, os carbonatos da Serra da Bodoquena.

\subsection{Geomorfologia regional}

Almeida (1965) estabeleceu uma primeira compartimentação geomorfológica da área de estudo, onde se observam cinco compartimentos (Figura 2.4): Pantanal, Zona Cristalina Ocidental, Serra da Bodoquena, Zona Serrana Oriental, Depressão Periférica do Miranda e Vale do Rio Apa. Segundo Almeida (1965, p. 81) a Serra da Bodoquena "é a mais importante feição geomorfológica regional, não só pelas altitudes a que se eleva, dentro do quadro de planícies do sul do Mato Grosso, como por sua extensão". 


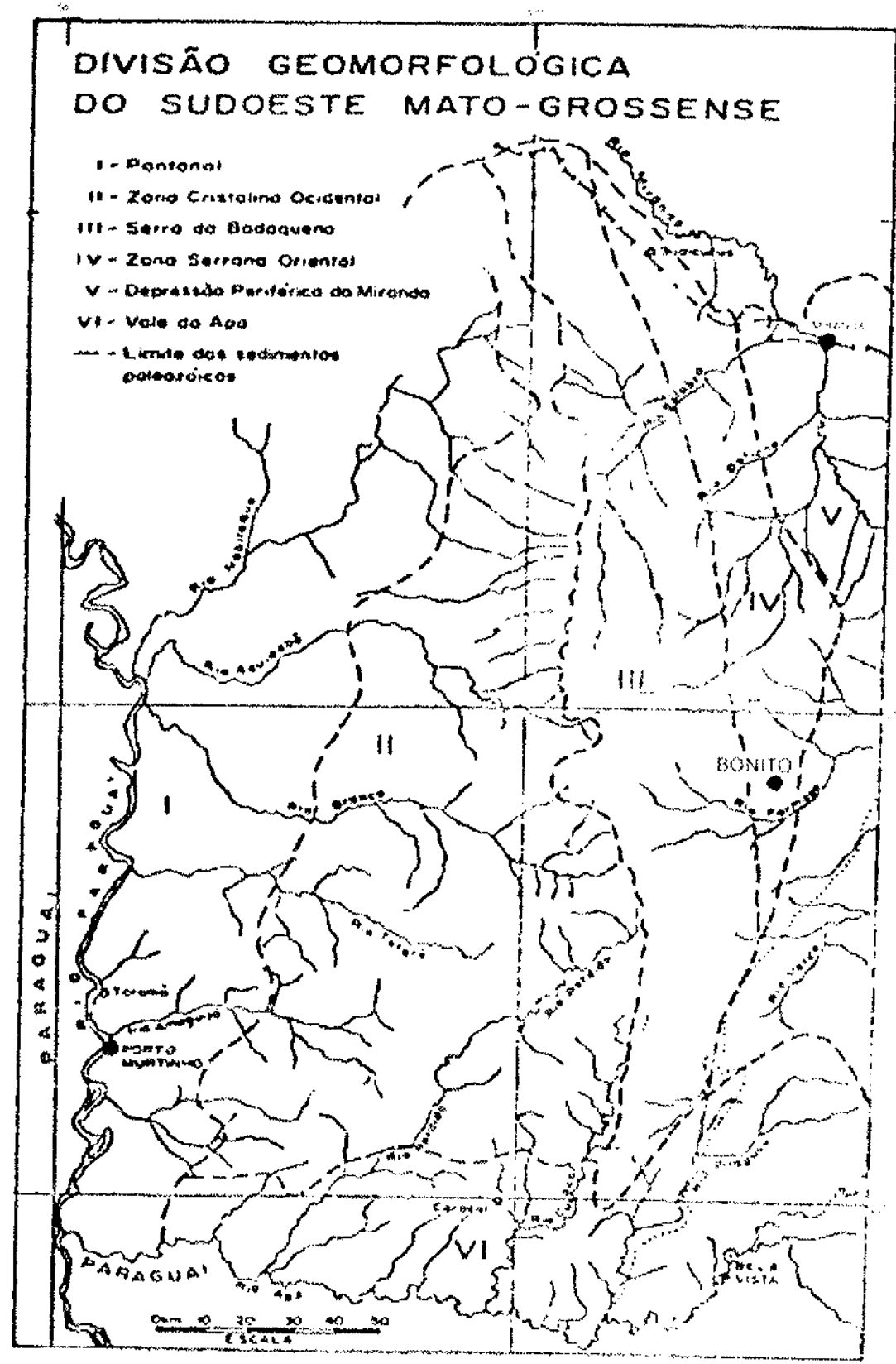

Figura 2.4: Divisão geomorfológica regional segundo Almeida (1965). I- Pantanal; IIZona Cristalina Ocidental; III- Serra da Bodoquena; IV- Zona Serrana Oriental; VDepressão Periférica do Miranda; VI- Vale do Rio Apa.

Almeida (1965) descreve a Serra da Bodoquena como um planalto cálciodolomítico, estreito e extenso, com a borda ocidental escarpada e borda oriental que termina bruscamente ou em degraus em relação à Zona Serrana Oriental. Na sua porção norte a Serra da Bodoquena apresenta-se como morros de dolomitos isolados. Em relação ao carste, Almeida (1965) descreve algumas feições cársticas, e coloca que a Serra da Bodoquena apresenta-se como um "carst incompletamente desenvolvido", o que surpreende pelo fato de que nesta região existem todas as condições favoráveis para o desenvolvimento do relevo cárstico, como clima úmido e desnível topográfico.

Em relação ao carste, Almeida (1965, p. 83-84) descreve: 
"Viajando-se na Bodoquena, certamente depara-se com aspectos típicos do relevo calcário. A hidrografia é em parte subterrânea; adaptados às direções tectônicas, sobretudo nas regiões dobradas da borda oriental, os cursos d'água perdem-se freqüentemente, em sumidoros, típicos avens afunilados, como o exibido na fotografia 15. Diz-se que grande parte do córrego Lalima e alguns de seus afluentes, na zona norte do planalto, tem desenvolvimento subterrâneo, e que o próprio rio Formoso no municipio de Bonito, assim se apresenta em seu alto curso. Um ou outro pequeno lago existe sobre o planalto; sobrevoamos um deles na zona norte. É de supor que ocupem dolinas". (...) "Embora tenhamos visto, no planalto da Bodoquena, muitas das feições características do carst, certo é que outras faltam ou escasseiam. Nunca vimos uma dolina típica, seja no terreno ou indicada nas fotografias aéreas que atentamente examinamos, de grande área da zona norte. A despeito da existência de cursos subterrâneos, pareceu-nos que a maior parte da drenagem seja superficial, fluindo em vales que se apresentavam secos por ocasião de nossas viagens, realizadas no rigor da estiagem. Não parece existirem poldjés. $O$ vale do córrego Lalima sugere tal feição, mas sua origem é certamente outra, ligada como se acha, à erosão de uma anticlinal dolomitica com a exposição do núcleo, em Formação Cerradinho. A natureza grandemente detrítica desta formação explica o relevo suave da depressão, uma centena de $m$ mais baixa que as cristas dolomíticas vizinhas, e a presença de solos ácidos, no interior de um planalto predominantemente constituido de rochas carbonatadas". "De tal modo, apresenta-se a Bodoquena como um carst incompletamente desenvolvido, e isso é surpreendente quando se consideram as condições favoráveis ali reunidas para o desenvolvimento do relevo cárstico. As rochas carbonatadas existem por toda parte, em pacotes de centenas de $m$ de espessura, expostos em clima relativamente úmido, cuja pluviosidade deve oscilar entre 1200 e $1300 \mathrm{~mm}$ e, o que é importante, concentra-se nos meses de mais elevadas temperaturas. O planalto ergue-se suficientemente acima do nível das planicies do Pantanal para que seja grande a solicitação à infiltração subterrânea da drenagem".

Assim, Almeida (1965) já havia reconhecido a existência de carste na Serra da Bodoquena, porém, como comentado por Sallun Filho et al. (2004) "este autor ressalta 
em suas conclusões uma incoerência entre as condições favoráveis para carstificação da região e a baixa incidência de feições cársticas notadas por ele". A importância do estudo de Almeida (1965) para o conhecimento da Serra da Bodoquena é discutida em Sallun Filho et al. (2004) que se encontra no Anexo 1.

Em trabalho mais recente, Alvarenga et al. (1982), no projeto RADAMBRASIL, reconheceram na área de estudo quatro unidades geomorfológicas: o Planalto da Bodoquena, o Planalto de Maracaju-Campo Grande, a Depressão do Rio Paraguai, as Planícies e Pantanais Matogrossenses. A classificação de Alvarenga et al. (1982) é adotada neste trabalho, apenas acrescentando a Depressão Periférica do Rio Miranda de Almeida (1965), que estaria incluída na Depressão do Rio Paraguai de Alvarenga et al. (1982).

Na classificação de Almeida (1965) o carste corresponde às unidades da Serra da Bodoquena e de parte da Zona Serrana Oriental, respectivamente, na classificação de Alvarenga et al. (1982) ao Planalto da Bodoquena e, a Depressão do Rio Miranda e ao Planalto de Maracaju-Campo Grande. Porém, no trabalho de Alvarenga et al. (1982) poucas feições cársticas foram descritas.

Quatro unidades geomorfológicas principais são reconhecidas no Estado do Mato Grosso do Sul (Figura 2.2):

1) o Planalto de Maracaju-Campo Grande (Alvarenga et al., 1982) que regionalmente inclui-se nos Planaltos da Bacia do Paraná (Ross, 2000), ocupa o setor leste da área de estudos, sendo uma superfície suavemente dissecada, onde predominam formas tabulares muito amplas e relevos conservados (200-650 m) (Alvarenga et al., 1982), condicionado pelas rochas sedimentares e vulcânicas da Bacia do Paraná (Ordoviciano-Cretáceo) (Figura 2.2). Seu limite oeste é marcado pela erosão remontante da cobertura sedimentar, associada à borda leste do Pantanal, expondo uma superfície erosiva pré-carbonifera, formando extensas planícies desenvolvidas na Depressão do Rio Paraguai, na borda do Planalto da Bodoquena.

2) o Planalto da Bodoquena (Alvarenga et al., 1982) ou Serra da Bodoquena (Almeida, 1965), que regionalmente inclui-se nas Serras Residuais do Rio Paraguai (Ross, 2000), constitui um conjunto de serras dispostas na direção norte-sul, onde o corpo principal é a Serra da Bodoquena. Apresenta relevo dissecado com porções conservadas, associados principalmente ao relevo cárstico (Alvarenga et al., 1982). Tem caráter residual por encontrar-se circundado pela Depressão do Rio Paraguai e é um importante divisor de águas (Alvarenga et al., 1982). Abrange rochas 
carbonáticas e terrigenas do Grupo Corumbá (Neoproterozóico III), composto neste compartimento de calcários da Formação Bocaina e de rochas terrigenas e carbonáticas (calcíticas e dolomíticas) da Formação Cerradinho (de menor expressão em área) (Figura 2.2 e Anexo 5a). As rochas carbonáticas estão distribuídas na região formando principalmente duas faixas de direção norte-sul, onde predominam a oeste os calcários e a leste os dolomitos, que correspondem em geral respectivamente ao Planalto da Bodoquena e às planícies da Depressão do Rio Miranda.

3) a Depressão do Rio Paraguai (Alvarenga et al., 1982; Ross, 2000) que inclui a Depressão do Rio Miranda e a Zona Serrana Oriental de Almeida (1965), constitui uma vasta superficie rebaixada (cota de 100-350 m) limitada à leste pelo Planalto de Maracaju-Campo Grande, a oeste e sudoeste pelas planícies do Pantanal sendo interrompida pelo Planalto da Bodoquena, que se ergue na sua parte central (Alvarenga et al., 1982) (Figura 2.2 e Anexo 5a). É constituída, na parte oeste, por rochas do embasamento granito-gnáissico (Paleoproterozóico). Na parte leste é conhecida como Depressão do Rio Miranda (devido ao rio de mesmo nome), e é formada por rochas terrígenas e carbonáticas (principalmente dolomíticas) dos grupos Corumbá e Cuiabá da Faixa Paraguai (Neoproterozóico III) (Figura 2.2 e Anexo 5a).

4) as Planicies e Pantanais Matogrossenses (Alvarenga et al., 1982; Ross, 2000; Almeida, 1965), correspondem a depósitos arenosos (colúvio-aluviais) de uma bacia sedimentar cenozóica de até $500 \mathrm{~m}$ de espessura condicionada pela subsidência de blocos de falhas (Figura 2.2) (Assine \& Soares, 2004). As rochas do Planalto da Bodoquena e da Depressão do Rio Paraguai encontram-se parcialmente soterradas pelos sedimentos da Bacia do Pantanal.

Segundo Ross (2000) a Serra da Bodoquena pertence as Serras Residuais do Alto Paraguai, juntamente com a Provincia Serrana no Mato Grosso, que se caracteriza por "formas residuais de dobramentos datados do Pré-cambriano, cujos processos erosivos geraram forma de relevo em conjuntos de serras assimétricas e grosseiramente paralelas que atingem até $800 \mathrm{~m}$ de altitude". Assim os planaltos da Bodoquena e de Maracaju-Campo Grande parecem representar remanescentes da chamada Superficie Sul-Americana de idade provavelmente do Mioceno (Soares \& Landim, 1976) e a 
formação do Pantanal teria ocorrido após a geração desta superfície de erosão (Assine \& Soares, 2004). Estudos na Bacia do Paraná indicam que os sedimentos neoordovicianos se estendiam até a Bolivia e o Paraguai, recobrindo as rochas carbonáticas da Serra da Bodoquena (Assine et al., 1998). Aparentemente no Carbonífero a área se encontrava em elevação no chamado Arco de Assunção, atuando como área fonte de parte da Formação Aquidauana (Gesicki, 1996). As rochas da Bacia do Paraná provavelmente recobriram parte do que é atualmente a Depressão do Rio Miranda, porém resta dúvida se teriam recoberto também as rochas no Planalto da Bodoquena, como será discutido nos itens a seguir.

O único trabalho que trata especificamente da geomorfologia cárstica na área de estudos é de Kohler et al. (1998), que apesar da pequena quantidade de dados, propõem uma classificação geomorfológica em quatro unidades: o Fluviocarste do Rio Perdido, Morros Residuais, Planícies Cársticas e Fluviocarste dos tributários do Rio Miranda. 


\section{MATERIAIS E MÉTODOS}

Para este estudo foi realizado um mapeamento morfológico e litológico inicial, com a aplicação de técnicas morfométricas, que permitiram identificar compartimentos morfológicos distintos, com posterior estudo geológico das cavernas e seus espeleotemas, bem como da influência da tectônica recente e elaborar um modelo evolutivo preliminar do sistema cárstico na área de estudo.

Definiu-se uma área de detalhe que abrange o setor central da Serra da Bodoquena onde os estudos se concentraram, devido à facilidade de acesso e a maior quantidade de informações já existentes, o que inclui trabalhos prévios, mapas topográficos e mapas geológicos em escala 1:50.000 (Figura 3.1).

\subsection{Compartimentação geomorfológica}

Para o estudo do relevo os mapas geológicos e topográficos foram compilados e digitalizados. Foram utilizadas técnicas de geoprocessamento e observações de campo para a caracterização morfoestrutural da área de estudos e identificação das feições cársticas, correlacionando-as a niveis geomorfológicos. A classificação dos terrenos se baseou na definição e identificação de áreas homogêneas.

A compartimentação geomorfológica e a extração de lineamentos foi realizada através de fotointerpretação de 80 fotos em escala 1:60.000, auxiliada por imagens do satélite LANDSAT 7. Cada compartimento foi demarcado com base na identificação de suas feições cársticas, e o detalhamento desta compartimentação tiveram como base o Modelo Digital de Terreno (MDT) gerado e os índices morfométricos calculados.

\subsubsection{Digitalização de mapas topográficos}

Os documentos cartográficos foram compilados e digitalizados. Para tanto foram utilizadas 14 folhas topográficas na escala $1: 100.000$ de 1968 e 18 cartas militares na escala 1:50.000 de 1988, ambos da Diretoria de Serviço Geográfico do Exército (DSG) (Figura 3.2). Os mapas 1:100.000 abrangem toda a área estudada enquanto que os de escala 1:50.000 recobrem apenas parte desta.

A digitalização e análise do relevo foi realizada a partir dos mapas topográficos em escala 1:100.000 e 1:50.000. Os mapas 1:100.000 forneceram bons resultados, mas não permitiram uma análise morfométrica apurada devido à falta de resolução. Assim, apesar de não recobrirem totalmente a área de estudos, foram também utilizados os mapas em escala 1:50.000 por serem a maior escala disponivel, o que mostrou uma resolução bem superior que a escala 1:100.000. 


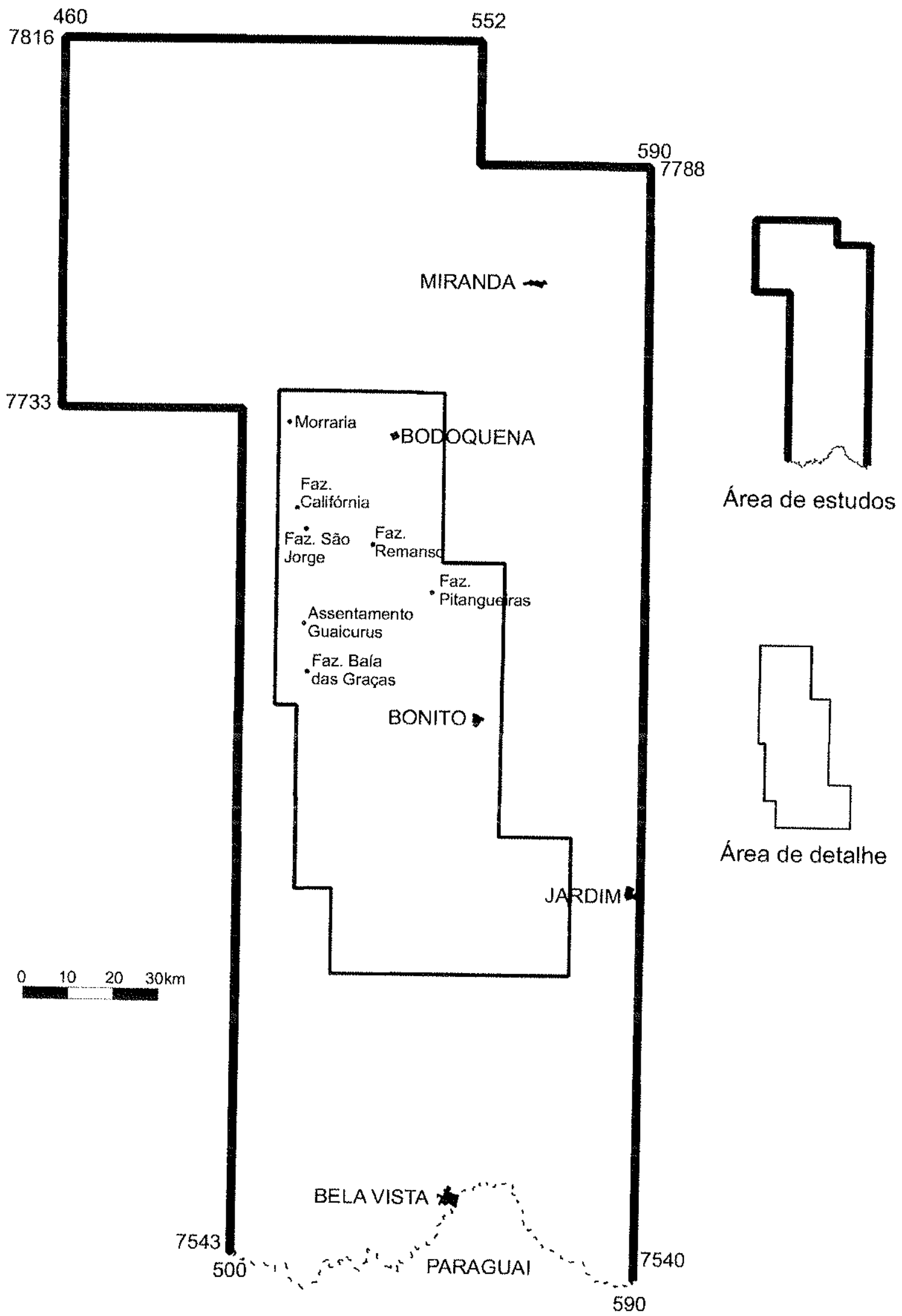

Figura 3.1: Localização da área de detalhe e das localidades principais. 
As curvas de nivel (com espaçamento de 40 e $20 \mathrm{~m}$ de acordo com a escala, respectivamente $1: 100.000$ e 1:50.000) e a rede de drenagem de cada folha topográfica foram digitalizadas usando-se o software AutoCAD R14 e mesa digitalizadora, utilizando valores segundo a Projeção Transversa de Mercator (UTM) para as coordenadas $\mathrm{X}$ e $\mathrm{Y}$ e altitude para $Z$.

\subsubsection{Análise da rede de drenagem}

Após a digitalização da drenagem a partir dos mapas topográficos 1:100.000 e 1:50.000 foi realizada a análise da rede de drenagem e gerado o mapa de densidade de drenagem. Através da rede de drenagem as bacias hidrográficas foram delimitadas, e o fluxo geral da drenagem superficial e a definição das possíveis rotas de fluxo da água subterrânea foram determinados. As possiveis zonas de recarga do aqüifero cárstico foram identificadas, delimitando zonas de recarga mista (alogênica e autogênica) e recarga autogênica, suportada pela análise de campo.

\subsubsection{Análise de imagens de radar e satélite}

As imagens de radar impressas do projeto RADAMBRASIL abrangem a maior parte da área na escala 1:250.000. A área de cobertura das imagens de radar pode ser vista na Figura 3.2, estas imagens digitalizadas, tratadas e referenciadas fornecem informações para análise estrutural. Porém foram utilizadas imagens mais recentes de maior resolução e em formato digital. Foram utilizadas imagens obtidas pelo projeto Shuttle Radar Topography Mission (SRTM, 2003) realizado pelas agências americanas NIMA (National Imagery and Mapping Agency) e NASA (National Aeronautics and Space Administration) e distribuidos pelo site http://strm.usgs.gov na resolução de $90 \mathrm{~m}$. $\mathrm{O}$ objetivo deste projeto foi de mapear a topografia do planeta utilizando radar.

Para a análise dos dados de sensoriamento remoto, foram utilizados recortes georeferenciados de 2 imagens multiespectrais do sensor ETM+ do satélite LANDSAT7. As imagens possuem órbita 226 e pontos 74 e 75 (obtidas em agosto de 2001). A área de cobertura das imagens pode ser vista Figura 3.2. As composições das imagens do satélite LANDSAT-7 foram processadas, utilizando-se o software ER-Mapper 6.3, utilizando as bandas utilizadas são: ETM+1, 2, 3, 4, 5, 6, 7 e 8 do sensor ETM+, sendo que a banda ETM+8 pancromática ( $15 \times 15 \mathrm{~m}$ de resolução) no visível e infravermelho próximo e a ETM+6 no infravermelho termal, enquanto as outras bandas apresentam resolução de $30 \times 30 \mathrm{~m}$. Foi realizada a fusão de todas as bandas que aumentou a resolução espacial $(15 \times 15 \mathrm{~m})$ com preservação das propriedades radiométricas. Para a 
composição das bandas foi utilizado o denominado "High Pass Filter Methơ" (Chavez Jr. et al., 1991), aplicação de filtros passa-alta, e a análise por componentes principais (PC1) para realce da informação textural. Filtros passa-alta eliminam as feições de baixa freqüência, deixando apenas as de altas freqüências (Crósta, 1993).

As imagens LANDSAT 7 foram tratadas visando uma melhor definição das formas de relevo. A utilização da $\mathrm{PC} 1$ se mostrou útil para realçar as formas de relevo. A aplicação de filtros direcionais se mostrou eficiente para definir as feições de relevo em grande escala. A banda 8 , com resolução de $15 \mathrm{~m}$, exibe uma resolução muito boa para o relevo, exibindo mais resolução que as outras bandas.

A utilização de imagens de satélite para classificação do relevo se mostrou muito eficiente em escala regional, mas não para detalhe.

\subsubsection{Fotointerpretação}

Foi realizada a fotointerpretação somente na área de estudo em detalhe, para identificação das feições cársticas, extração de lineamentos estruturais e da rede de drenagem. Apesar da escala não ser a ideal para este tipo de estudo as fotografias mostraram-se satisfatórias as feições cársticas da região.

Para esta análise foram utilizadas 75 fotografias aéreas, escala 1:60.000, da

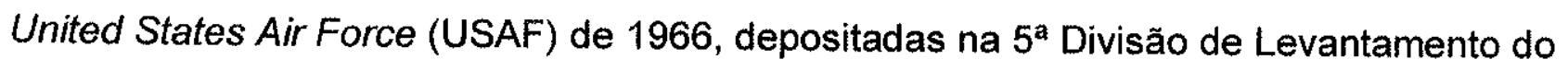
Exército Brasileiro. A área de cobertura das fotografias aéreas pode ser vista na Figura 3.2. Após a definição das áreas de detalhe iniciou-se a fotointerpretação nestas áreas, o que correspondeu a 75 fotografias aéreas. 


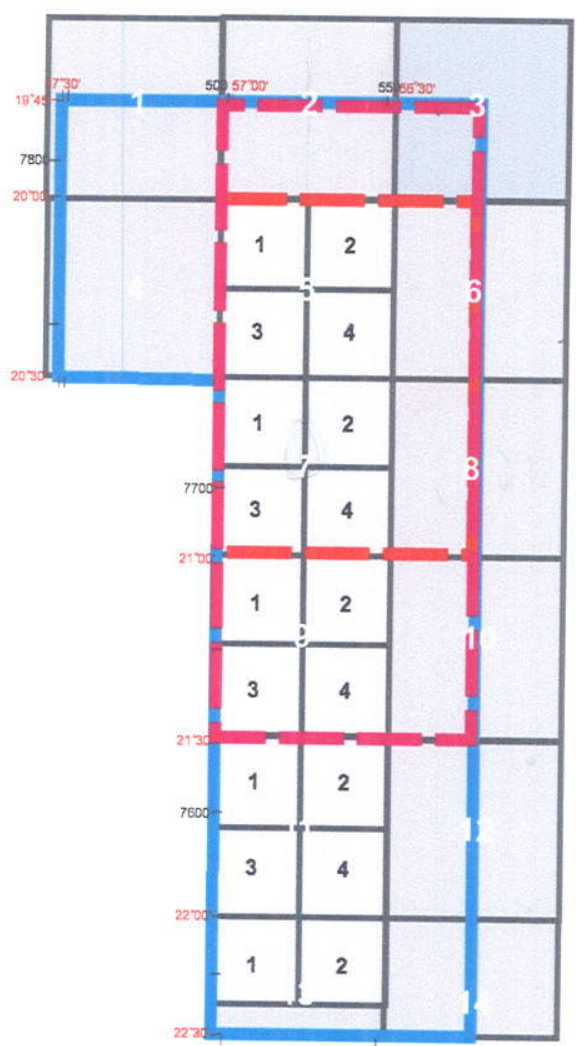

Projeto RADAMBRASIL (1982) - Folhas SF.21 e SE. 21/20 Escala 1: 1.000 .000

Godoi \& Martins (1999)

CPRM - Folha Campo Grande (SF21)

1.000 .000

Neto et al. (1976)

Escalas 1:250.000 e 1:500.000

Godoi (2001) - CPRM

Folha Aquidauana (SF. 21-X-A)

Nogueira \& Oliveira (1978) - CPRM

Escalas 1:50.000 e 1:250.000
Folhas 1:100.000

1. Porto Esperança

2- Barranco Vermelho

MI - 2509 / SE-21-Z-C-IV

3- Porto Ciriaco

MI - 2510 / SE-21-Z-C-V

Ml - 2546 / SF-21-V-B-II

Folhas 1:50.000

\begin{tabular}{|c|c|}
\hline $\begin{array}{l}\text { 5- Coronel Juvêncio } \\
\text { MI - } 2547 \text { / SF-21-X-A-I }\end{array}$ & $\begin{array}{l}\text { 1- Fazenda Bodoquena - Ml - 2547/1 } \\
\text { SF-21-X-A-l-1 } \\
\text { 2-Saloba - MI - 2547/2 } \\
\text { SF-21-X-A-I-2 } \\
\text { 3- Morro do Veado - MI - 2547/3 } \\
\text { SF-21-X-A-I-3 } \\
\text { 4-Córego Potreiro - MI - 2547/4 } \\
\text { SF-21-X-A-I-4 }\end{array}$ \\
\hline $\begin{array}{l}\text { 7- Vila Campão } \\
\text { MI - 2583 / SF-21-X-A-IV }\end{array}$ & $\begin{array}{l}\text { 1- Morraria - MI - 2583/1 } \\
\text { SF-21-X-A-V-1 } \\
\text { 2- Bodoquena - MI - 2583/2 } \\
\text { SF-21-X-A-IV-2 } \\
\text { 3- Serra da Agua Limpa - MI - 2583/3 } \\
\text { SF-21-X-A-IV-3 } \\
\text { 4-C6rrego Brejão - MI - 2583/4 } \\
\text { SF-21-X-A-IV-4 }\end{array}$ \\
\hline $\begin{array}{l}\text { 9- Rio Perdido } \\
\text { MI-2619 / SF-21-X-C-I }\end{array}$ & $\begin{array}{l}\text { 1- Vila Rica - MI - 2619/1 } \\
\text { SF-21-X-C-I-1 } \\
\text { 2- Bonito - - - MI - 2619/2 } \\
\text { SF-21-X-C-I-2 } \\
\text { 3- Curvelo-MI - 2619/3 } \\
\text { SF-21-X-C-I-3 } \\
\text { 4-Corrego Aurora - MI - 2619/4 } \\
\text { SF-21-X-C-I-4 }\end{array}$ \\
\hline $\begin{array}{l}\text { 11- Fazenda Margarida } \\
\text { MI - 2654 / SF-21-X-C-IV }\end{array}$ & $\begin{array}{l}\text { 1- Fazenda Margarida - MI - 2654/1 } \\
\text { SF-21-X-C-IV-1 } \\
\text { 2-Vila Gaúcha - MI - 2654/2 } \\
\text { SF-21-X-C-IV-2 } \\
\text { 3-Córego do Boi - MI - 2654/3 } \\
\text { SF-21-X-C-IV-3 } \\
\text { 4- Córrego Jaguaretê - MI - 2654/4 } \\
\text { SF-21-X-C-IV-4 }\end{array}$ \\
\hline $\begin{array}{l}\text { 13- Bela Vista } \\
\text { MI - 2688 / SF-21-Z-A-I }\end{array}$ & $\begin{array}{l}\text { 1 e 3-Córrego Agua Azul - MI - 2688/1 e } 3 \\
\text { SF-21-Z-A-l-1 e } 3 \\
2 \text { e } 4 \text { - Bela Vista - MI - 2688/2 e } 4 \\
\text { SF-21-Z-A-I-2 e } 4\end{array}$ \\
\hline
\end{tabular}

MI - 2689/ SF-21-Z-A-II

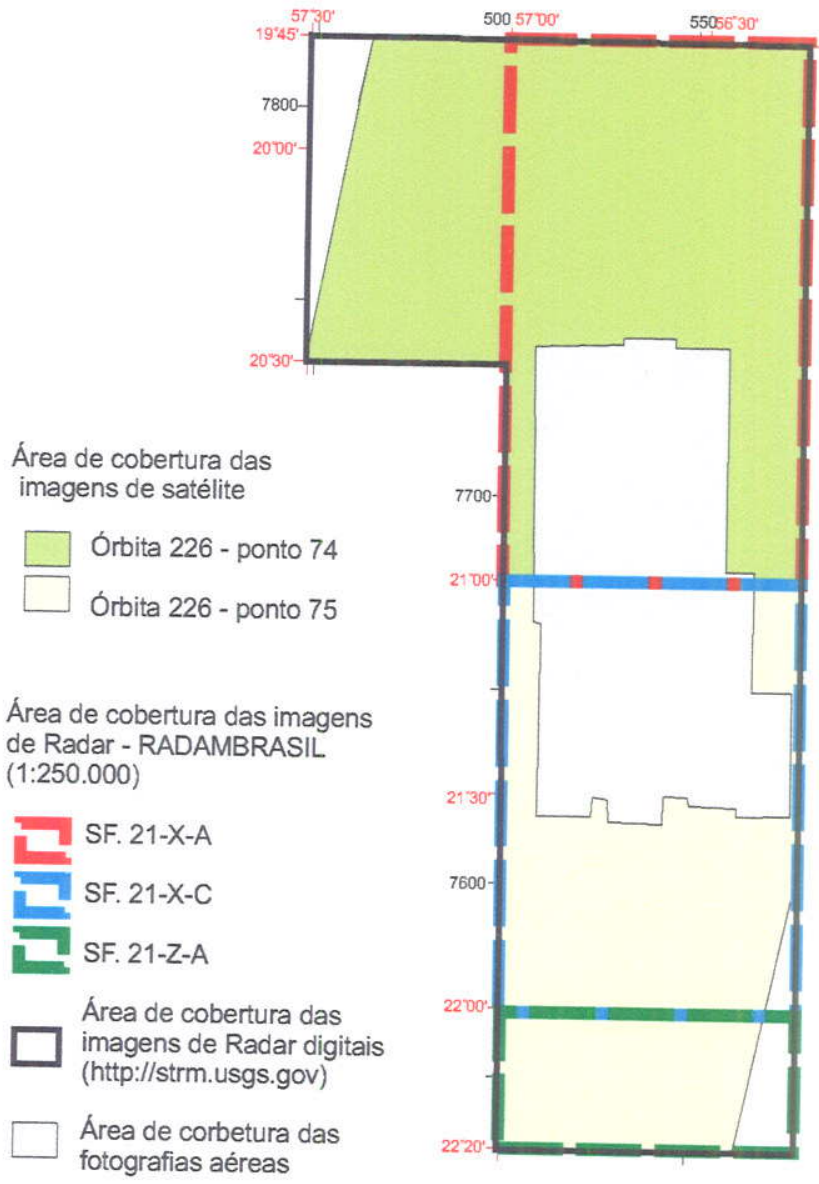

Figura 3.2: Áreas de cobertura dos mapas topográficos, geológicos, fotografias aéreas, imagens de radar e satélite. 


\subsubsection{Análise do relevo em campo}

Foram realizados levantamentos e mapeamento de feições cársticas em campo, como cones cársticos, dolinas, sumidouros e ressurgências.

Para o mapeamento dos cones cársticos utilizou-se medições sucessivas de Global Positioning System (GPS) com altímetro digital embutido, e posterior geração de mapas. O levantamento destas feições em campo foram necessárias, pois os mapas não possuem escala suficiente para quantificá-las e muitas destas feições (principalmente as menores) não podem ser identificadas nas fotos aéreas ou imagens de satélites devido à escala.

As dolinas foram mapeadas quanto a sua localização, forma em planta e em perfil e suas características geológicas. Observou-se em campo uma quantidade de dolinas muito maior do que o esperado, optando-se assim pela definição de algumas áreas de amostragem.

\subsubsection{Análise morfométrica do relevo}

Foram utilizados produtos de sensoriamento remoto e geradas cartas temáticas utilizando Sistema de Informação Geográfica (SIG) para análise morfométrica do relevo.

A partir dos mapas topográficos nas escalas 1:100.000 e 1:50.000, vetorizados, foram elaborados o Modelo Digital de Terreno (MDT), mapa hipsométrico e extraídos os indices morfométricos.

O MDT foi gerado utilizando-se os softwares ARCVIEW GIS 1.8 e SURFER 8.0 a partir da base topográfica digitalizada. Para cada curva obtida na digitalização foi atribuído o valor de elevação em metros. Para a confeç̧ão do MDT pelo ARCVIEW 1.8 foi utilizado o método "triangular irregular network" (TIN) (Peuker et al., 1978) utilizando todos os pontos obtidos, que segundo Burrough \& McDonnell (2000) apresenta melhores resultados do que a utilização de grades regulares para a confecção de MDT, utilizados para o cálculo de hipsometria. Para a confecção do MDT pelo SURFER foi utilizado o método estatistico da krigagem com anisotropia igual a 1.

Foram gerados os seguintes produtos e índices:

- Mapa hipsométrico: foi confeccionado em classes altimétricas com espaçamento de $40 \mathrm{~m}$, de acordo com a resolução do mapa topográfico original em escala 1:100.000. O mapa hipsométrico destaca a distribuição e organização espacial das principais unidades de relevo, e representa a altura da área de estudo em relação ao nível do mar.

- Mapa de densidade de drenagem: a drenagem das folhas topográficas foi digitalizada com espaçamento de pontos de $100 \mathrm{~m}$, que corresponde a um ponto a cada 
$0,2 \mathrm{~cm}$ de linha de drenagem (Figura 3.3). Foi estabelecida uma malha quadrática com células de $2500 \times 2500 \mathrm{~m}$ para a área de estudos, onde o parâmetro de densidade de cada célula foi obtido a partir do número de pontos que cada célula continha;
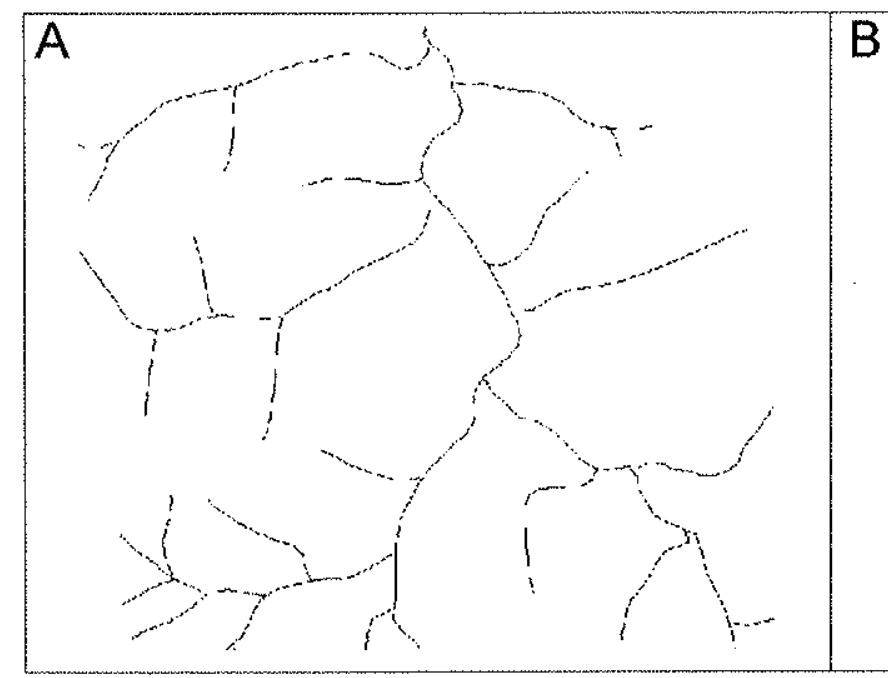

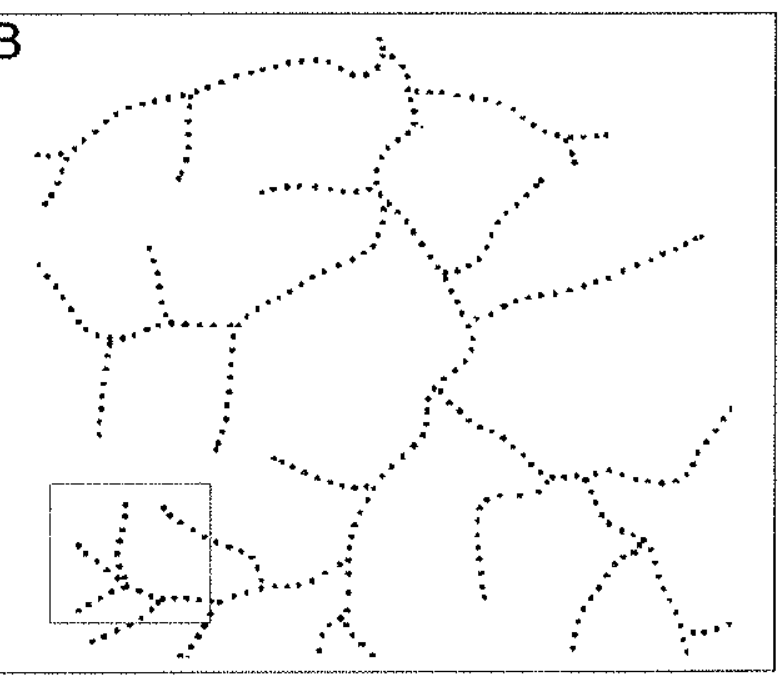

Célula de $2500 \times 2500 \mathrm{~m}$

Figura 3.3: Exemplo de uma drenagem de folha topográfica (escala 1: 50.000) (A) e os pontos utilizados para a digitalização dessa drenagem para a confecção do mapa de densidade de drenagem (B).

- Índice de rugosidade: foi confeccionado com base no MDT. Foram estabelecidas áreas correspondentes a trechos das unidades morfológicas. Para cada célula foi calculada a razão entre a área real e a área plana (Hobson, 1972). A rugosidade obtida nesta escala é útil para compararmos os diversos compartimentos, mas não permite uma comparação com outros locais, que seria possível através de índices produzidos pelo menos com mapas na escala 1:25.000.

- Densidade de cones (Dc) e de morros (Dm): Cones e morros residuais foram contados e a densidade calculada através do número de cones e morros dividida pela área da unidade $\left(\mathrm{km}^{2}\right)$. No caso dos morros residuais foi ainda calculada a proporção, em área, de morros em relação às planícies, obtendo-se a razão entre a área de morros e a área total da unidade.

- Dolinas: Para obter um parâmetro quantitativo da forma em perfil das dolinas, ou seja, perfil suave ou íngreme, calculou-se a razão entre a profundidade e o diâmetro (P/D). Quanto maior o valor de P/D mais íngreme é o perfil da dolina. White (1988) utiliza-se deste indice para diferenciar dolinas, poljes, corredores e canyons (mais largas que fundas, com índice menor ou igual a 1) de chaminés, poços, abismos e fendas (mais fundas do que largas, com índice menor que 1). 
Para obtenção de parâmetros que indicam a existência de atividade tectônica recente na área foram obtidos, segundo critérios estabelecidos por Keller \& Pinter (1996), as seguintes relações:

- índices de assimetria de drenagem (Af) através da razão entre a área do lado direito da bacia (Ar) e área total (At), multiplicada por 100;

- gradiente $(G)$ do rio através da razão entre o desnível topográfico e 0 comprimento em metros;

- índice de sinuosidade de escarpa (Smf) através da razão entre o comprimento real da escarpa (Lmf) e o seu comprimento linear (Ls);

- razão fundo-altura de vale (Vf) utilizando os parâmetros largura do vale (Vfw), altitude da margem esquerda (Eld), altitude da margem direita (Erd) e altitude do fundo do vale (Esc), através da Equação 1.

$$
V f=(2 V f w /(E l d-E s c)+(E r d-E s c))
$$

\subsection{Análise litológica-estrutural}

\subsubsection{Confecção da base geológica}

$\mathrm{Na}$ área de estudo existem mapas geológicos desde a escala de 1:1.000.000 até 1:50.000. A área inteira é coberta apenas por mapas em escala 1:1.000.000, 1:500.000 e 1:250.000. Os mapas em escala 1:50.000 e mapas 1:250.000 mais recentes existem apenas para uma parte da área. As articulações destes mapas encontram-se na Figura 3.2.

Todas as bases geológicas disponiveis foram compiladas para compor um mapa geológico regional (Anexos $5 a$ e b). Houve dificuldade em fazer esta compilação, pois os mapas estão em diversas escalas e são de épocas diferentes.

Para as áreas de detalhe foi utilizada uma compilação de mapas de maior detalhe e mais recentes.

\subsubsection{Pesquisas de campo}

Os trabalhos de campo foram divididos em nove etapas de campo, totalizando 72 dias. Nestes trabalhos de campo algumas regiôes foram percorridas e 165 pontos foram descritos. A distribuição destes pontos pode ser vista no Anexo 2. 
Todos os pontos foram localizados com GPS e lançados no mapa topográfico. A descrição dos pontos incluiu o tipo de rocha, medidas estruturais e coleta de amostras no caso de rochas carbonáticas.

A análise geológica-estrutural das áreas de detalhe é de fundamental importância para compreensão do relevo e das cavernas. O mapeamento e definição de áreas carbonáticas e não carbonáticas em campo é de extrema importância na análise do relevo.

Dos 165 pontos descritos foram tomadas 341 medidas, somadas a mais 123 medidas de outros projetos, totalizando 446 medidas estruturais incluindo fraturas, falhas e acamamento. Também foram utilizados na análise estrutural os dados existentes em mapas geológicos. A partir das medidas colhidas no campo foram elaborados estereogramas para acamamento, falhas e fraturas. Estes pontos foram agrupados em áreas homogêneas e posteriormente analisados. Para tratamento dos dados estruturais utilizou-se o software StereoNett 2.46. Todos os diagramas estruturais apresentados correspondem à rede de Schimidt-Lambert, tendo como referência a semiesfera inferior.

\subsubsection{Amostragem de rochas carbonáticas}

Dentre os 165 pontos descritos analisou-se 64 amostras rochas carbonáticas (de pontos distintos) para análises químicas dos elementos maiores $\left(\mathrm{CaO}, \mathrm{MgO}, \mathrm{SiO}_{2}\right.$, $\mathrm{Al}_{2} \mathrm{O}_{3}, \mathrm{MnO}, \mathrm{Na}_{2} \mathrm{O}, \mathrm{K} 2 \mathrm{O}, \mathrm{TiO}_{2}, \mathrm{P}_{2} \mathrm{O}_{5}, \mathrm{Fe}_{2} \mathrm{O}_{3}$ ) e perda ao fogo, somadas aos resultados analíticos de 83 amostras de Nogueira \& Oliveira (1978) totalizando 147 pontos de análise. As análises foram realizadas pelo Laboratório de Fluorescência de Raios $X$ (Departamento de Mineralogia e Geotectônica do IGc-USP). As rochas carbonáticas foram classificadas segundo a proposta de Leighton \& Pendexter (1962), onde são consideradas as quantidades de dolomita, calcita e impurezas. Como os resultados das análises de rocha são expressos em óxidos foram utilizadas as fórmulas de conversão de óxidos para termos mineralógicos descrita em Martinet \& Sougy (1961).

Para plotagem dos pontos das análises químicas utilizou-se o software TRIPLOT 4.1 (http://mypage.iu.edu/ thomps/programs/).

\subsection{Estudos morfológicos de cavernas}

\subsubsection{Compilação dos mapas existentes}

Em um primeiro momento houve um levantamento dos mapas existentes. Alguns já publicados, e outros gentilmente cedidos pelos autores. Após reunir todos os mapas 
existentes foi feita uma seleção daqueles que poderiam ser utilizados, pois alguns não têm informação e precisão suficientes (croquis). Apenas os croquis das cavernas subaquáticas foram utilizados (mesmo não tendo boa precisão), ao menos para uma primeira abordagem.

Os mapas utilizados foram digitalizados utilizando escaner e vetorizados em AutoCAD R14.

Algumas cavernas foram mapeadas em dois ou três projetos diferentes. Nestes casos os mapas foram compilados produzindo uma única base. O maior problema encontrado nestes casos é que os mapas foram produzidos em épocas diferentes e assim utilizaram técnicas distintas, o que nem sempre gera mapas com o mesmo padrão cartográfico. Em cavernas que possuem uma parte subaérea e outra subaquática há uma dificuldade ainda maior, pois em todos os casos a parte seca foi mapeada em separado da parte subaquática, por pessoas diferentes e utilizando outro nivel de precisão. Um exemplo de caverna nesta situação é a Gruta do Lago Azul.

Por isso as cavernas interessantes do ponto de vista morfológico e que não dispunham de mapas razoáveis foram re-mapeadas. Isto inclui também as cavernas subaquáticas, que mostram padrões interessantes para a compreensão da morfologia $e$ informações importantes para a compreensão do relevo e desenvolvimento de aqüífero.

Outro problema observado foi a falta da localização ou a localização precária de algumas cavernas, que foram localizadas novamente com GPS se a caverna é significativa.

\subsubsection{Mapeamento de campo e elaboração de mapas das cavernas}

Durantes os trabalhos de campo foram mapeadas 10 cavernas, somadas a mais 5 cavernas submersas mapeadas por mergulhadores, a partir de técnicas usuais de topografia usando bússola e clinômetro SUUNTO e trena.

Para o mapeamento de cavernas submersas as técnicas utilizadas são parecidas, onde se utiliza bússola e trena, mas o clinômetro é substituído por um profundímetro.

Após o mapeamento das cavernas em campo os dados obtidos com topografia foram tratados através do software SURVEX 1.0.9. Este software traça a "linha de trena" tridimensionalmente e partir dela se faz o desenho da caverna em planta e perfil no software AutoCAD R14. 


\subsection{Estudo da flutuação do nível d'água}

\subsubsection{Instalação de réguas e monitoramento}

Para o estudo da variação do nível d'água foram instaladas réguas de referência para monitoramento do nível d'água nas cavernas Lago Azul e Mimoso ao longo de um ano hidrológico, de julho de 2002 a julho de 2003. No Abismo Anhumas já existe uma régua, desde setembro de 2001, e os dados (registrados diariamente) foram fornecidos pela equipe que realiza a operação turística do abismo.

As réguas foram confeccionadas em alumínio, com graduação de $20 \mathrm{~cm}$ pintada com tinta. Foram instaladas com spits de ancoragem em rocha e o local escolhido para sua colocação foi o mais discreto possível, visto que são grutas turísticas.

O monitoramento da flutuação do nível d'água foi feito periodicamente, por funcionários da prefeitura na Gruta Lago Azul, por Ismael Escote (mergulhador) na Gruta Mimoso e pelos funcionários da equipe do Abismo Anhumas.

\subsubsection{Datação absoluta de espeleotemas}

No total foram coletadas 21 amostras de espeleotemas das grutas Mimoso, Lago Azul e Anhumas para datação absoluta. As profundidades das amostras subaquáticas foram medidas utilizando profundímetro, onde o "zero" corresponde ao nível d'água do momento da medição, calibrado com as réguas de monitoramento no momento da coleta.

As coletas se iniciaram em julho de 2002, após a expedição das licenças em abril/2002 e abril/2003 pelo Centro Nacional de Estudo, Proteção e Manejo de Cavernas - CECAV-IBAMA (Licenças n 001/02 e 021/03 - Proc. $n^{\circ}$ 02001.000757/01-91) e junho/2002 no caso da Gruta Lago Azul pelo Instituto do Patrimônio Histórico e Artístico Nacional - IPHAN (Ofício $n^{\circ}$ 001/02). É importante salientar que houve o comprometimento na preservação das cavernas locais e a coleta foi criteriosa, em pontos favoráveis e preferencialmente de espeleotemas quebrados. As coletas foram sempre acompanhadas por técnicos do CECAV-IBAMA, do núcleo do Mato Grosso do Sul. Nas coletas de espeleotemas submersos houve a cooperação de uma equipe de mergulhadores especializados em mergulho em cavernas.

Os espeleotemas selecionados foram datados pelo método ${ }^{230} \mathrm{Th} /{ }^{234} \mathrm{U}$ com o uso de ICP-MS em calcita. A princípio podem-se obter idades inferiores a aproximadamente $500 \mathrm{Ma}$ com $\pm 1 \%$ de erro (Gascoyne, 1992; Ford, 1996). O procedimento de análise laboratorial do método é descrito em Li et al. (1989), Ludwig et al. (1992), Kaufman (1998) e Shen et al. (2002). A aplicação do método ${ }^{230} \mathrm{Th} /{ }^{234} \mathrm{U}$ na datação absoluta de 
espeleotemas requer algumas condições essenciais, como teor mínimo de $U$ das amostras e ausência de contaminação por Th detrítico (Li et al. 1989; Atkinson et al. 1978). As datações foram realizadas pelo pesquisador Xianfeng Wang do Department of Geology and Geophysics, University of Minnesota (Minneapolis, EUA).

Foram confeccionadas lâminas petrográficas para a determinação do grau de alteração das amostras e selecionar os melhores pontos para retirada de aliquotas para datação. A laminação e estruturas como hiatos deposicionais ou indícios de redissolução (lixiviação) foram observadas na análise petrográfica, para definir os melhores pontos (mais preservados) para extração das amostras em fragmentos utilizando broca diamantada. Também se extraiu pó para analisar o teor de urânio pelo método de ativação neutrônica (realizado no IPEN-USP). Estas análises foram necessárias para seleção e verificação da viabilidade para geocronologia pelo método de U/Th. As amostras que apresentaram boa preservação (sem alteração das características deposicionais) e com teores de urânio adequados foram selecionadas para datação.

Além disto as análises petrográficas, de difratometria de Raios- $X$ e microscopia eletrônica de varredura (MEV) foram utilizadas para compreensão da gênese dos espeleotemas coletados, especialmente os formados abaixo do nivel d'água (subaquáticos), como os cones e as crostas.

Para a identificação mineralógica dos espeleotemas, as amostras foram moídas em almofariz de ágata para difração de raios $X$. As análises foram executadas em difratômetro de raios $X$ da marca SIEMENS D5000, do Departamento de Mineralogia e Geotectônica do IGC-USP, utilizando radiação CuKa.

As seções delgadas foram confeccionadas na Seção de Laminação de Rochas do IGC-USP, com espessura em torno de $30 \mu$. Para a descrição das lâminas foi utilizado microscópio óptico Olympus, modelo BXP 40, do Laboratório de Microscopia do IGCUSP.

A textura dos cones foi analisada por MEV, da marca LEO, modelo 440i, do Laboratório de Microscopia Eletrônica de Varredura do Departamento de Geologia Sedimentar e Ambiental do IG-USP (Processo FAPESP 95/5635-4). 


\section{GEOMORFOLOGIA CÁRSTICA}

\subsection{Rede de drenagem}

O estado do Mato Grosso do Sul possui duas grandes bacias hidrográficas, a do Rio Paraná a leste e a do Rio Paraguai a oeste, separadas pela Serra de Maracaju, que coincide em parte com a borda leste do Pantanal Matogrossense (Figura 4.1).

A Serra da Bodoquena está inserida na Bacia Hidrográfica do Rio Paraguai. Essa bacia é subdividida em sub-bacias, nas quais as dos rios Apa, Miranda e Nabileque abrangem a área da Serra da Bodoquena (Figura 4.1). A Serra da Bodoquena é o divisor de água entre estas bacias, onde parte das águas escoam para oeste (Bacia do Rio Nabileque), parte para leste (Bacia do Rio Miranda) e parte para sul (Bacia do Rio Apa) (Figuras 4.2A e B).

A maior parte da serra está inserida na bacia do Rio Miranda. O limite entre as bacias dos rios Miranda e Nabileque, na Serra da Bodoquena, é a escarpa oeste do Planalto da Bodoquena. Já o limite entre as bacias dos rios Miranda e Apa é dado pelas cotas topográficas mais altas do Planalto da Bodoquena.

Assim o Planalto da Bodoquena é um grande divisor de águas entre estas três bacias e o divisor central entre elas ocorrem na porção central da serra, nas cotas mais altas do planalto, justamente nas cabeceiras dos rios Salobra e Perdido (Figuras 4.2A e $B$ ). Estes rios estão entre os principais da serra, juntamente com os rios Formoso, Prata, Betione, entre outros, que compõe estas três bacias.

Os setores da Serra da Bodoquena ocupadas rochas carbonáticas possuem, de forma geral, pouca drenagem superficial, especialmente no Planalto da Bodoquena (Figura 4.2C). Outras áreas com pouca drenagem, como na parte norte da serra se deve a áreas alagadas do Pantanal Matogrossense, que apesar de não terem rios, possuem inúmeros lagos (Anexo 2). 


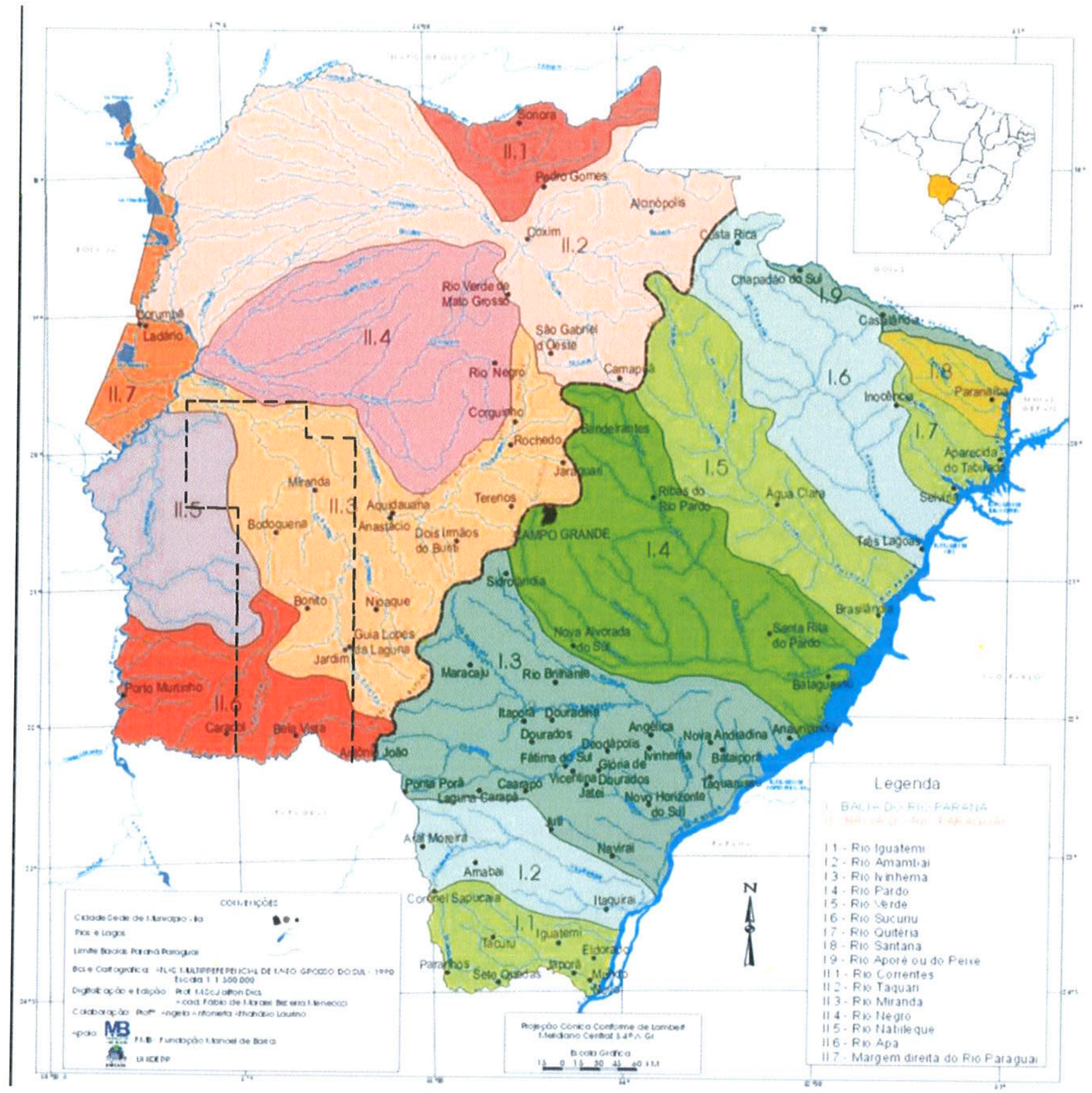

Figura 4.1: Bacias e sub-bacias hidrográficas do Estado do Mato Grosso do Sul (Extraído de http://www2.uniderp.br/Atlas/bhidro.htm). 
A

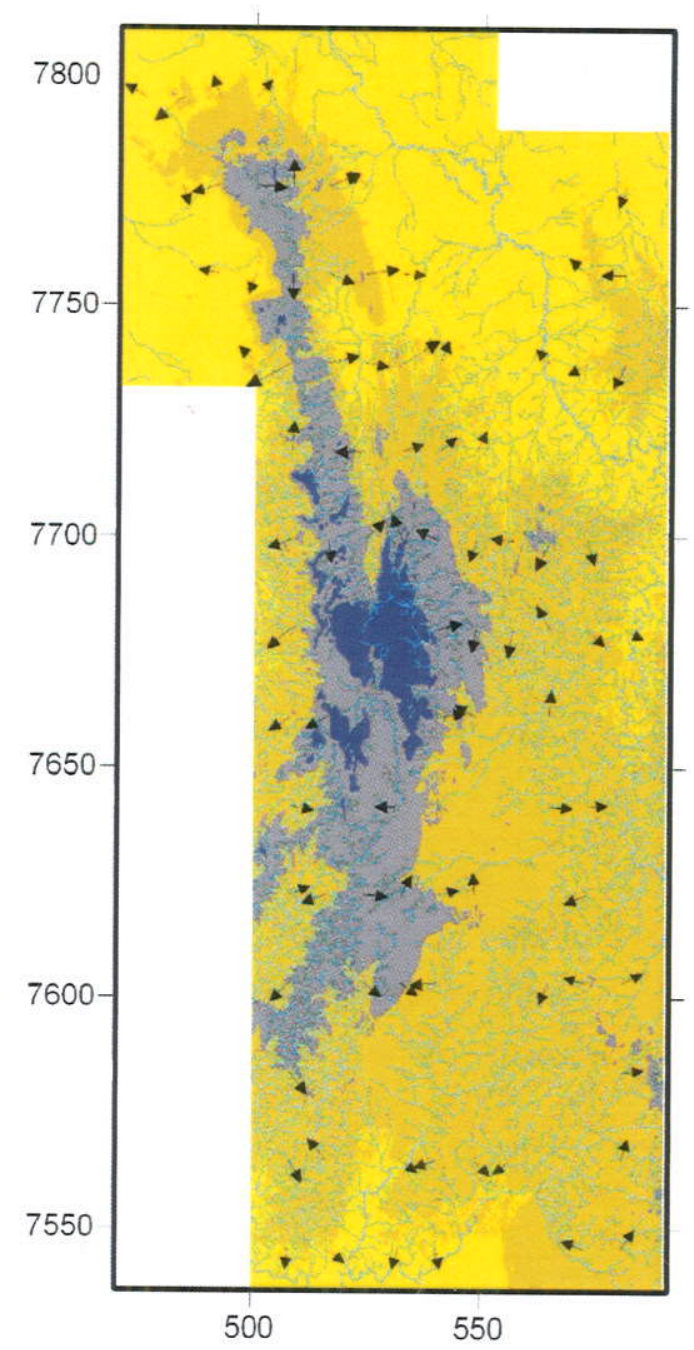

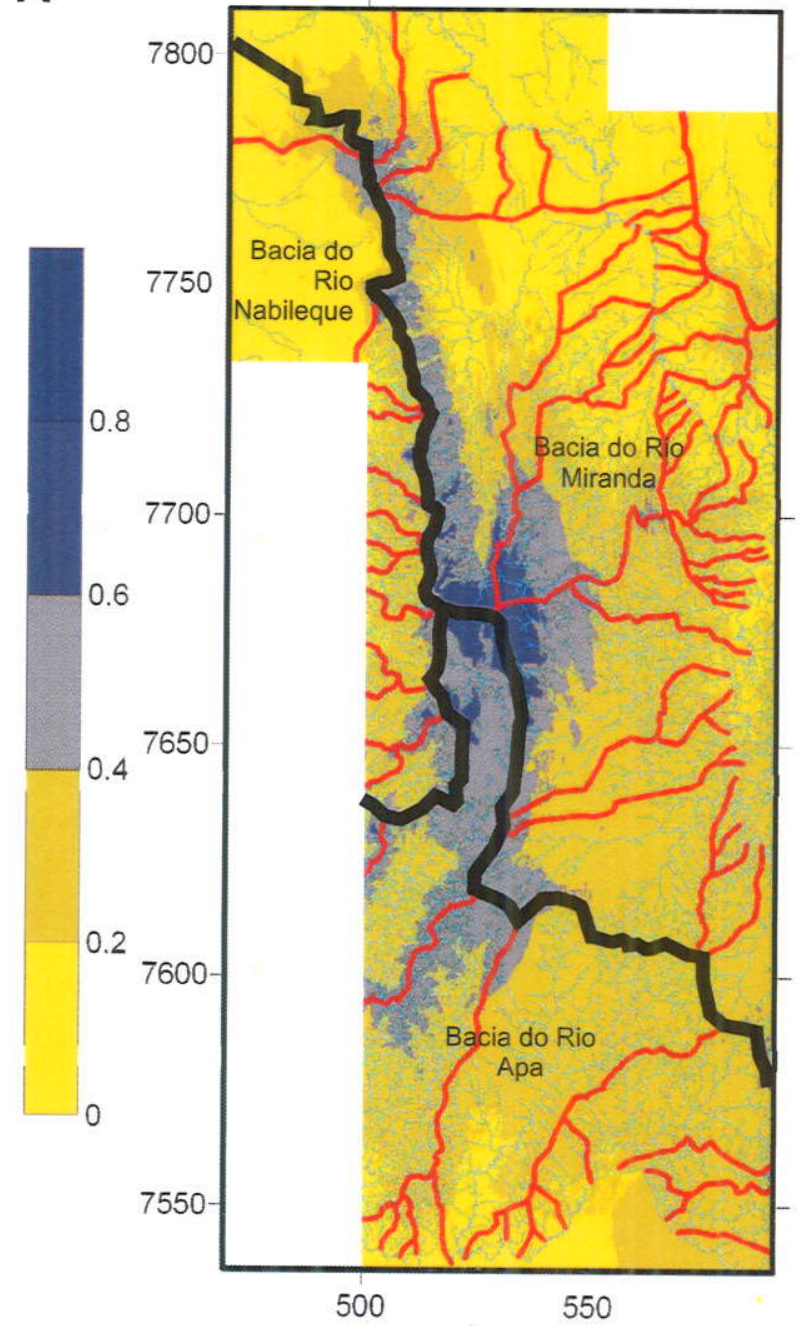

B

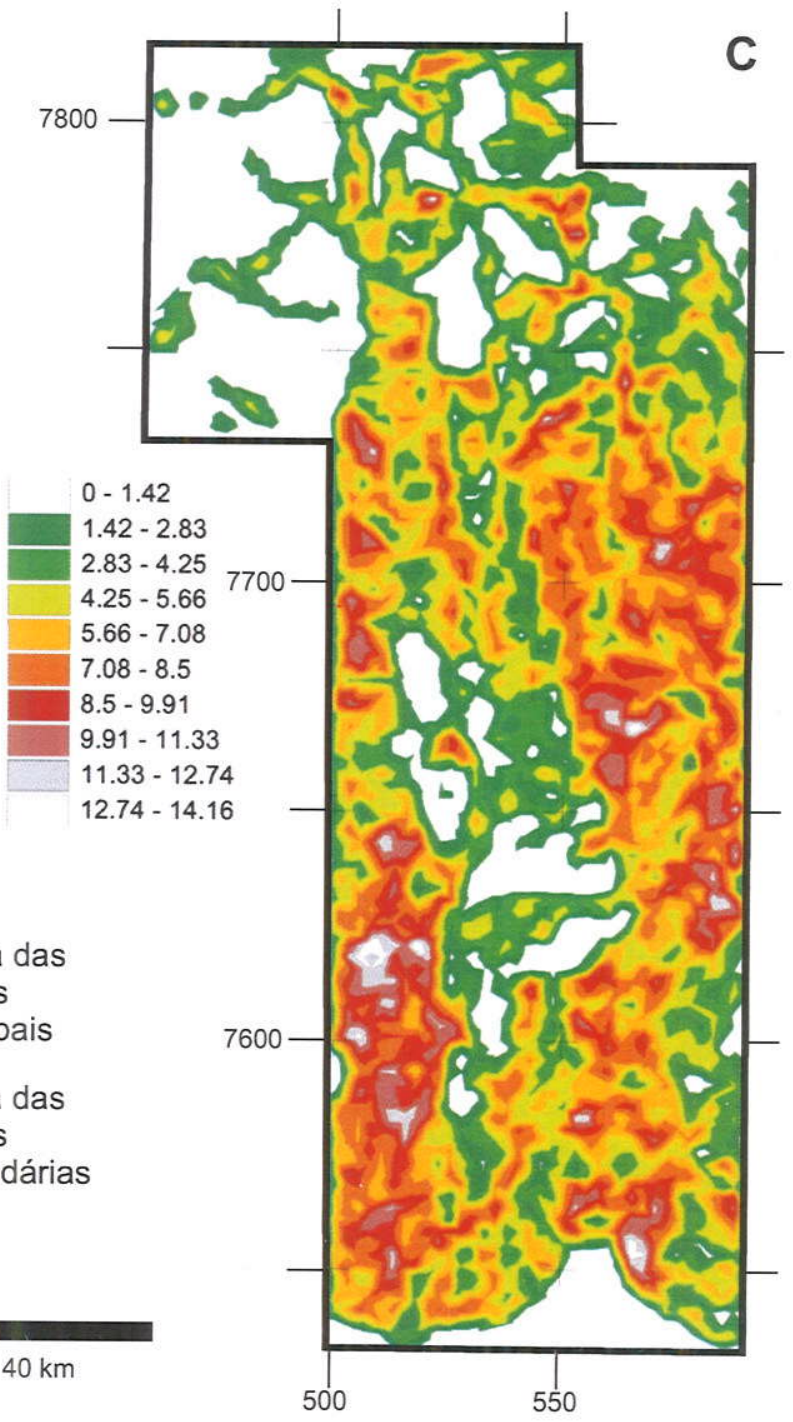

Divisa das

bacias

principais

Divisa d
bacias

secundárias

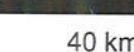

500 


\subsection{Compartimentação geomorfológica}

O mapeamento morfológico permitiu identificar unidades geomorfológicas com base na incidência de diferentes conjuntos de feições cársticas. Neste quadro distinguem-se zonas com predominância de processos cársticos em contraste com zonas com predominância de processos fluviais (Figura 4.2, 4.4 e Anexo 4). Com relação à recarga hídrica, o Planalto da Bodoquena e a Depressão do Rio Miranda caracterizam um sistema cárstico de recarga livre (autogênico e alogênico), enquanto o Planalto de Maracaju-Campo Grande representa um sistema interestratal, coberto pelos arenitos da Formação Aquidauana.

Foram identificados seis compartimentos morfológicos que são descritos a seguir e resumidos na Tabela 4.1 e na Figura 4.4.

Estes compartimentos estão distribuídos no Planalto da Bodoquena e na Depressão do Rio Miranda, descritos no Capítulo 2.3, e visualizados na Figura 4.3. 


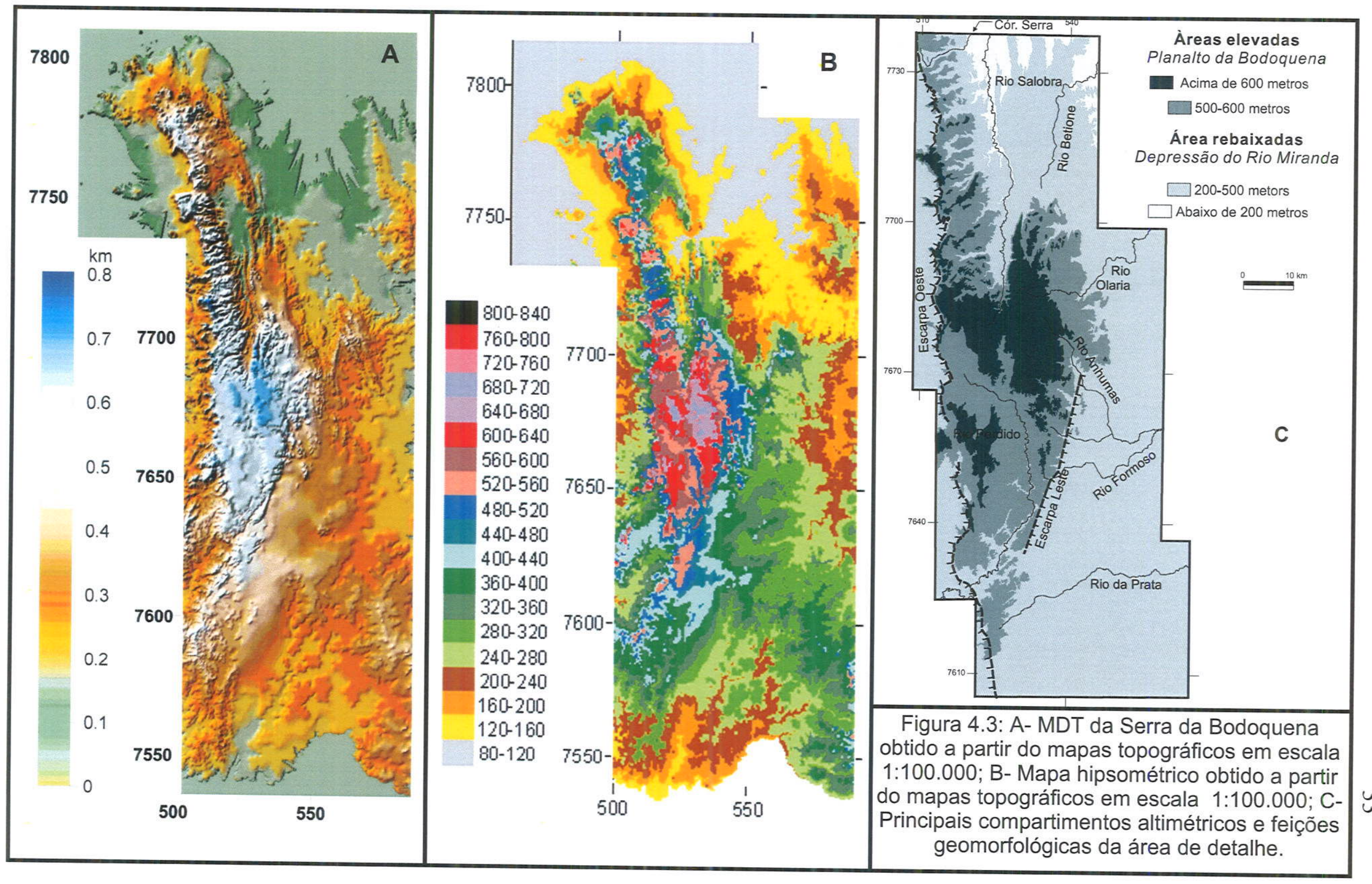


Tabela 4.1: Compartimentos morfológicos do carste da Serra da Bodoquena.

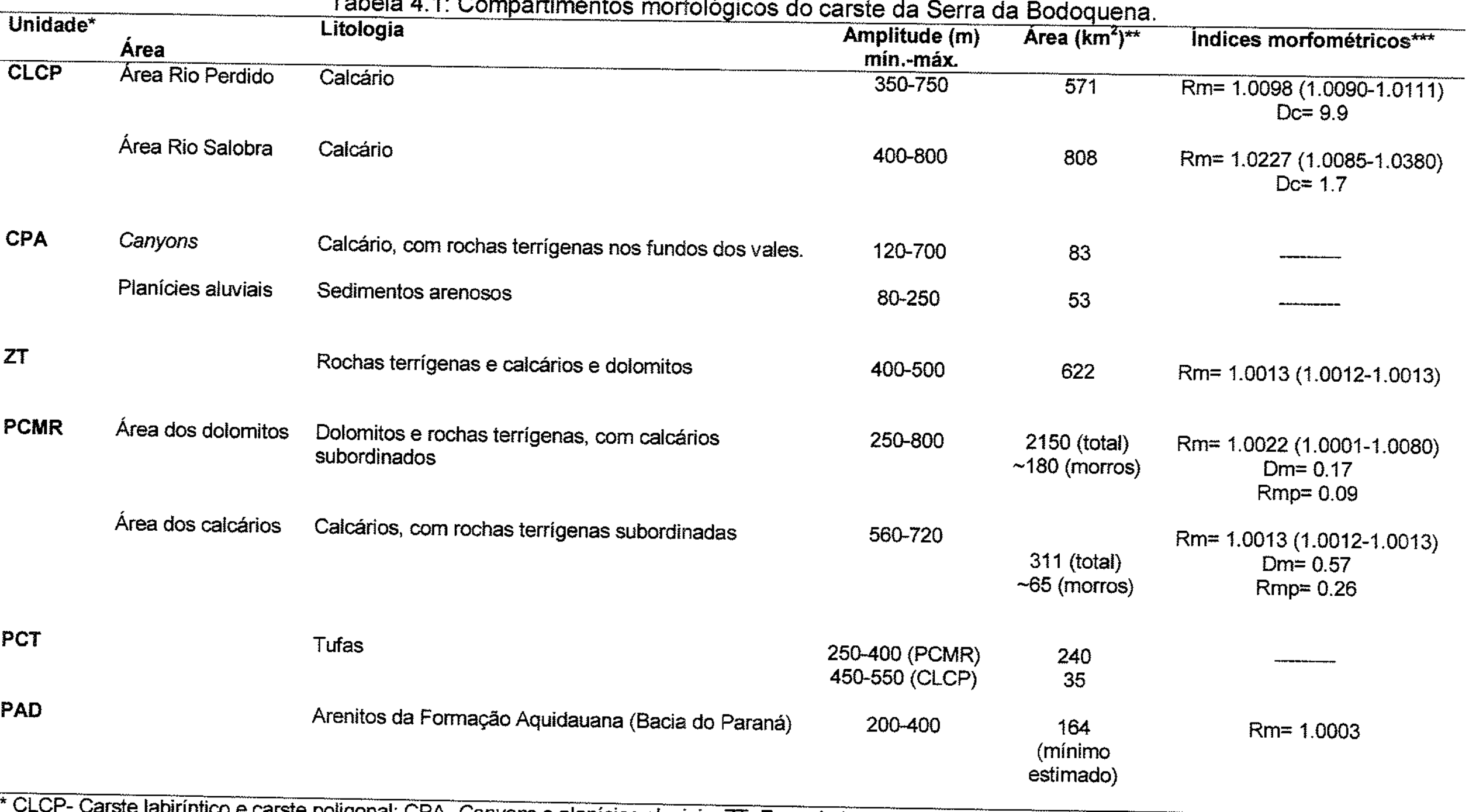
*CLCP-Carste labiríntico e carste poligonal; CPA- Canyons e planícies aluviais; ZT-Zona de transição; PCMR-Planícies cársticas com morros residuais; PCT-
Planícies com coberturas de tufas; PAD-Planícies areniticas com dolinas.

** medida apenas na área de detalhe.

${ }^{* * *} R_{m}$-rugosidade média (Min-Max); Dc- densidade de cones; Dm- densidade de morros; Rmp-razão morros/planícies (área). 


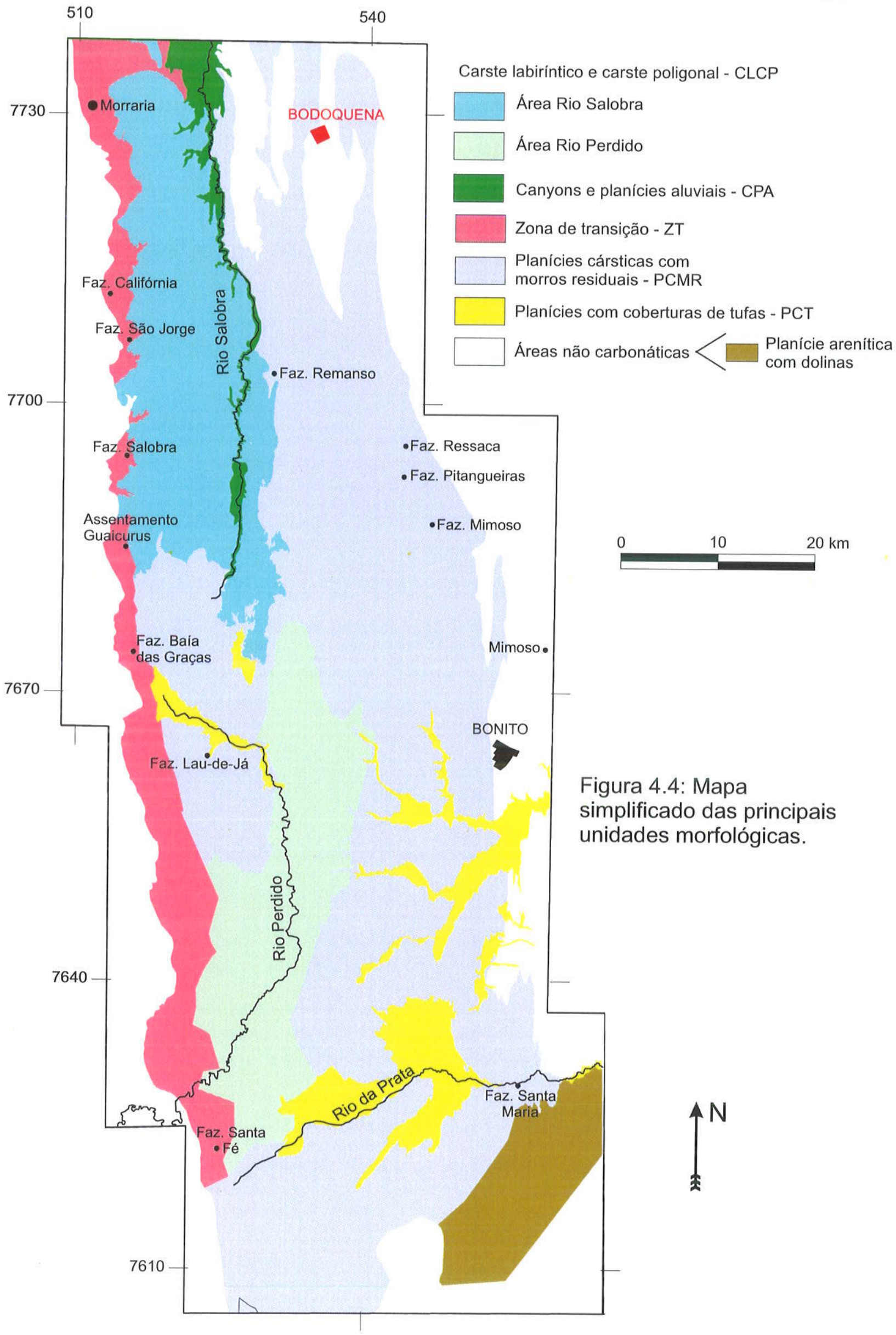




\subsubsection{Carste labiríntico e carste poligonal - CLCP}

Esta unidade ocorre essencialmente no Planalto da Bodoquena (Anexo 4). O solo é pouco espesso ou ausente. Divide-se em dois setores, um a sul com predomínio dos processos cársticos (Área Rio Perdido, Figuras 4.5B e 4.6B, C) e outra a norte com maior influência fluvial (Área Rio Salobra, Figuras 4.5A e 4.6A), que correspondem aproximadamente às bacias hidrográficas dos rios Perdido e Salobra. Ocorre na área de calcário do Planalto da Bodoquena (Anexo 5a).

O termo carste labirintico (labyrinth karst) foi definido por Brook \& Ford (1978) no carste de Nahanni (Canadá) para descrever um carste dominado por formas verticais interligadas por redes de fraturas e corredores. Foi descrito por White (1988) como um tipo de relevo cárstico dominado por corredores e canyons de dissolução interligados. Da mesma forma, Ford \& Williams (1989) definem o carste labirintico como corredores interligados ou alinhados.

\subsubsection{1. Área Rio Perdido}

Representa um carste de recarga principalmente autogênica caracterizado por trechos de carste labiríntico e trechos com carste poligonal (Anexo 4).

A estruturação geral das rochas neste compartimento é de um sinclinal aberto, com eixo norte-sul, e mergulhos predominantes entre 10 a $20^{\circ}$ (Anexo $5 \mathrm{~b}$, perfis I-I' e M-M'). A superficie correspondente ao carste poligonal e carste labirintico apresenta rugosidade de 1.0098, na escala topográfica de 1:50.000. O solo é em geral ausente e quando ocorre é pouco espesso com afloramentos do epicarste com karren em alguns pontos (Figura 4.9F). Os rios de superficie são raros ou ausentes (Figura 4.2), com uma circulação de águas dominantemente subterrânea através de sistemas freáticos associados a nascentes na escarpa leste junto ao contato com a unidade PCMR. A principal drenagem deste setor, o Rio Perdido, surge em nascentes cársticas (Figura $4.9 E$ ), percorre seu alto curso em superficie e no seu médio curso possui dois trechos subterrâneos antes de voltar à superfície definitivamente no seu baixo curso (Figura 4.7). Nos trechos subterrâneos do Rio Perdido observa-se em superfície um vale fluvial abandonado (vale seco), inclusive com depósitos de tufas, evidenciando uma fase de superficie antes de ter sido capturado por condutos (Anexo 4).

O carste labiríntico forma um relevo tabular recortado por karren de várias formas, observáveis em escalas desde afloramento até imagem de satélite (Figuras 4.6C e 4.7). Os mais freqüentes são fendas e corredores retilíneos com paredes verticais e com fundo estreito e plano, de largura métrica a decamétrica e extensão quilométrica. Os 
maiores corredores ocorrem no extremo sul desta unidade onde alcançam até 6,5 de comprimento, $500 \mathrm{~m}$ de largura e $100 \mathrm{~m}$ de profundidade (Figura $4.6 \mathrm{C}$ e 4.7 ). Estes corredores às vezes possuem incidência de dolinas ao longo de sua base. A orientação das fendas de dissolução segue o sistema de fraturas verticais com direções preferenciais segundo NE e N-NW, imprimindo um padrão reticulado ao conjunto de fendas (Figuras 4.5, 4.6B e $\mathrm{C}$ e 4.7). O topo plano no domínio do carste labirintico é atribuído ao remanescente de uma antiga superfície de erosão, pois corta a estrutura das rochas carbonáticas, nivelando os topos das cristas e morros (Figura 4.10, perfis $7665,16 ; 7655,85 ; 7645,08)$.

Originalmente esta unidade foi classificada como pavimentos cársticos (Sallun Filho et al., 2004), e posteriormente redefinida como carste labiríntico. Esta diferenciação é principalmente devido à escala, onde os pavimentos cársticos são feições de escala mesoscópica enquanto o carste labirintico e de escala megascópica (Brook \& Ford, 1978). Pavimentos cársticos ocorrem tanto na área de carste labirintico quanto nas áreas de carste poligonal. Apresentam-se como superficies planas, decamétricas, recortadas por inúmeras fendas desde centimétricas até métricas, algumas com alguns metros de profundidade, formando alguns pequenos abismos.

$\mathrm{O}$ carste labiríntico passa gradativamente para áreas de carste poligonal, próximo à planície do Rio Perdido (Figuras 4.6B e C e 4.9C). O carste poligonal é constituído de depressões poligonais amplas de fundo plano com drenagem centripeta e cones cársticos (Figuras 4.6B, 4.9A, B, C e D). Possui como característica principal a grande quantidade de cones. Contou-se cerca de $5657 \mathrm{em} 571 \mathrm{~km}^{2}$, o que fornece uma densidade de cones (Dc) de 9.9 por $\mathrm{km}^{2}$ (Tabela 4.1). Os cones se distribuem nas bordas de fendas e depressões. As depressões poligonais possuem amplitude de cerca de $50 \mathrm{~m}$, diâmetros variáveis e fundo quase plano. No Ponto 48, próximo ao Rio Perdido foi mapeada uma pequena depressão rodeada por cones para obtermos um parâmetro quantitativo de altura, pois nas fotografias aéreas 1:60.000 é impossivel delimitar os cones ou estimar as alturas (Figura $4.9 \mathrm{~A}$ ). $O$ resultado pode ser visto na Figura 4.8, onde a amplitude (do ponto mais baixo da depressão até o cone mais alto) é de 41,2 $\mathrm{m}$ no ponto 48 e de $62,2 \mathrm{~m}$ no ponto 49 (Figura 4.9B). Claramente se vê um alinhamento dos cones e de partes da depressão a N61E (Figura 4.9B). Em seção transversal apresentam perfis convexos desde simétricos a assimétricos, com vertentes que variam entre 10 a $23^{\circ}$ de inclinação (Figura 4.9B). Não caracterizam torres cársticas ou mogotes que possuem vertentes verticais (White, 1988). 
O nível d'água é raso, aflorando no fundo das depressões na época de chuva. Enquadra-se dentro da definição de carste dominado por cones (cone karst) de White (1988) onde predominam vertentes convexas ao contrário do cockpit karst que possui formas côncavas.

As cavernas neste compartimento são raras e de pequeno desenvolvimento. Seus padrões morfológicos predominantes são de condutos simples meandrantes, e secundariamente de redes anastomosadas (Capitulos 5.3.2 e 5.3.3). 


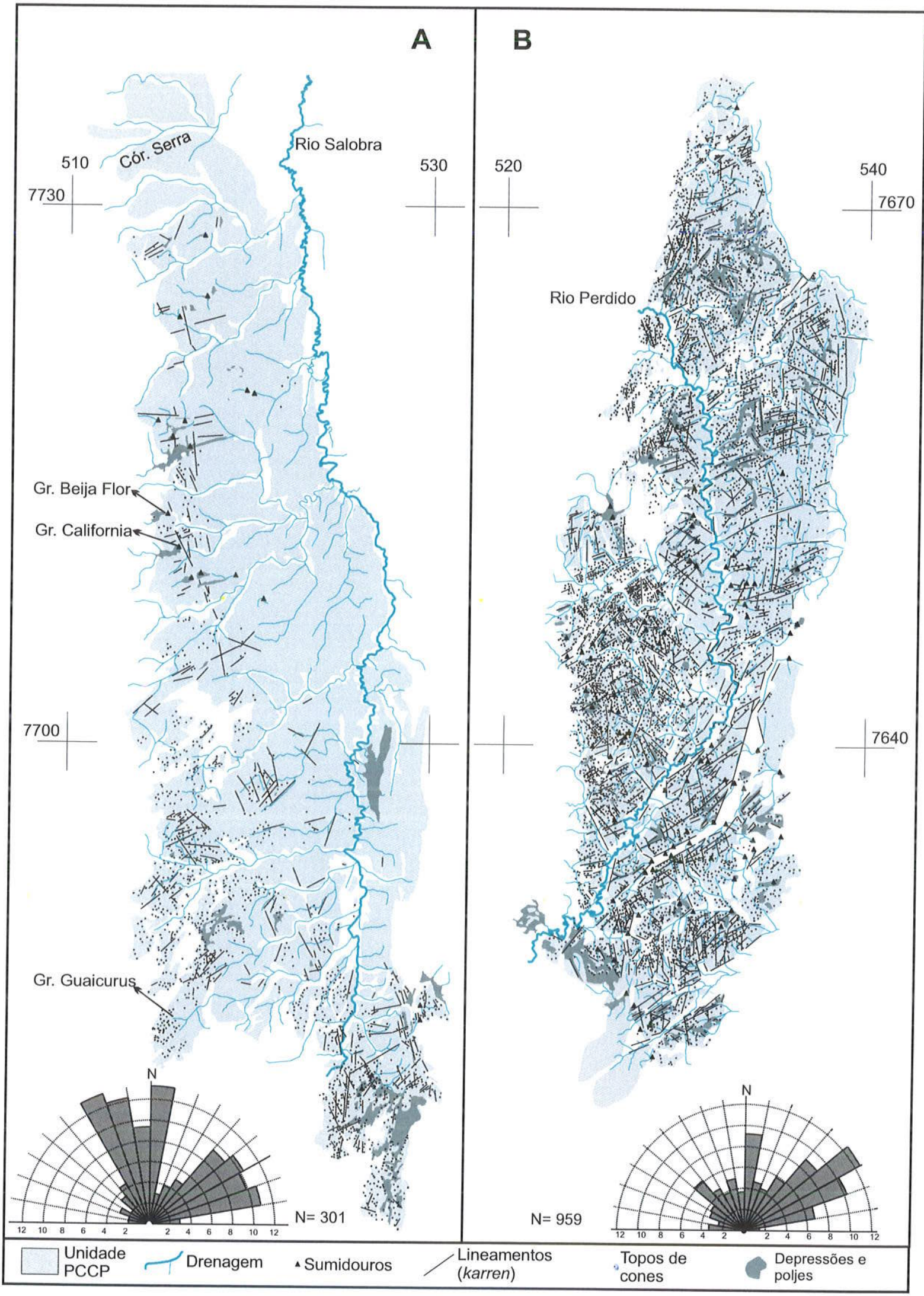

Figura 4.5: Feições cársticas da unidades PCCP (áreas Rio Salobra e Perdido), com respectivas rosáceas. 

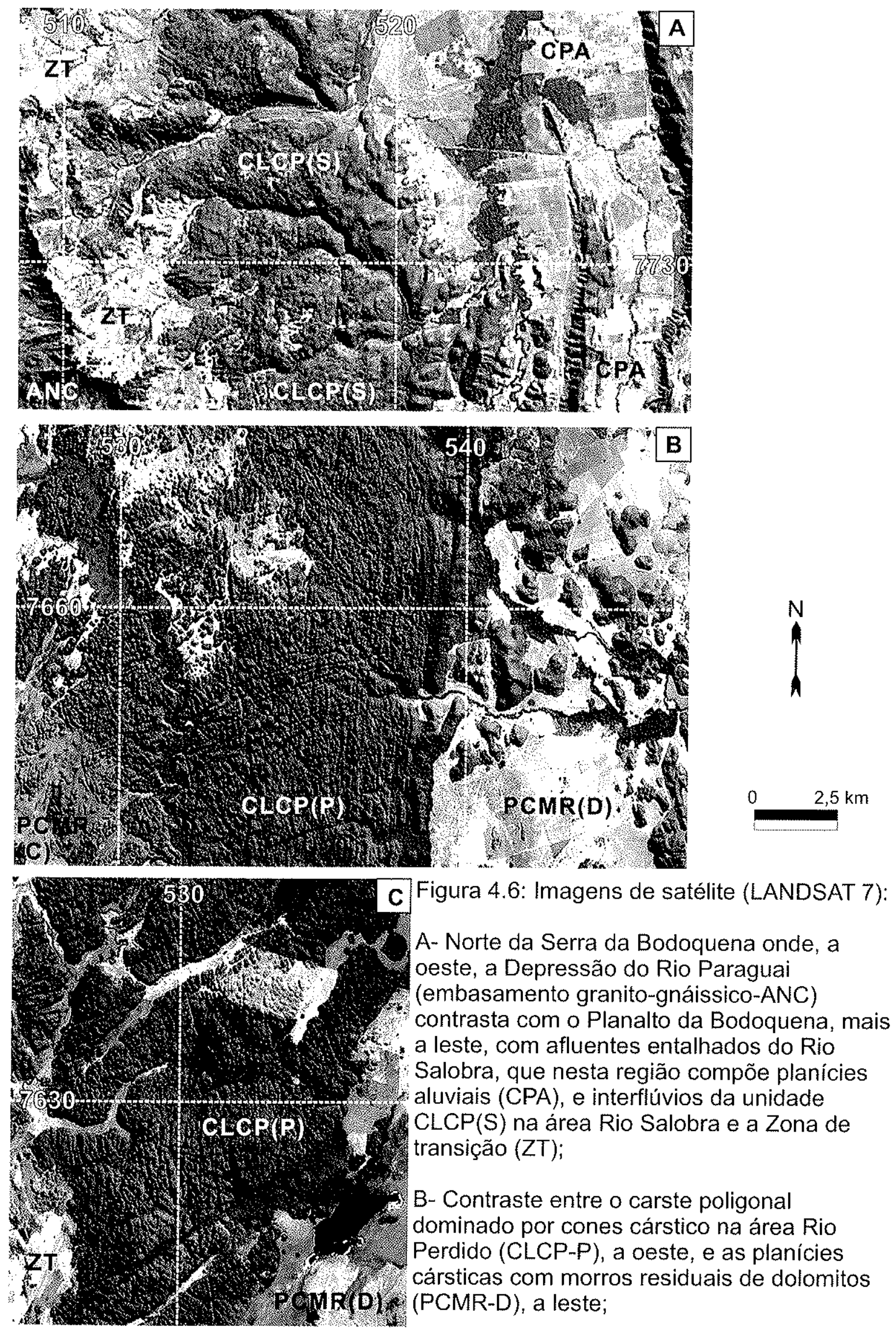

C- Carste labirintico na porção sul do Planalto da Bodoquena (CLCP-P), com corredores de grandes dimensões. 

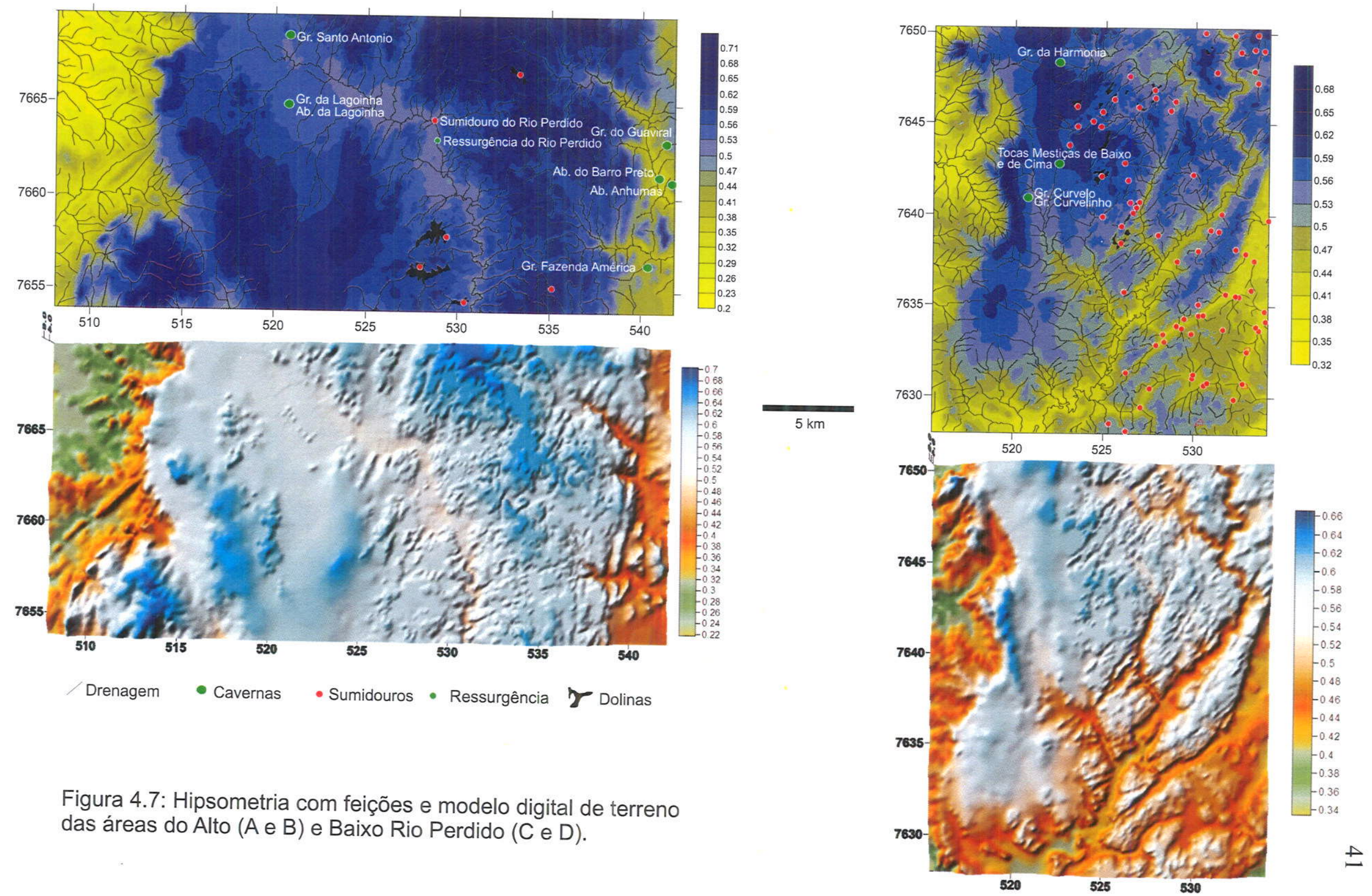

Figura 4.7: Hipsometria com feições e modelo digital de terreno das áreas do Alto $(A$ e $B)$ e Baixo Rio Perdido ( $C$ e D). 


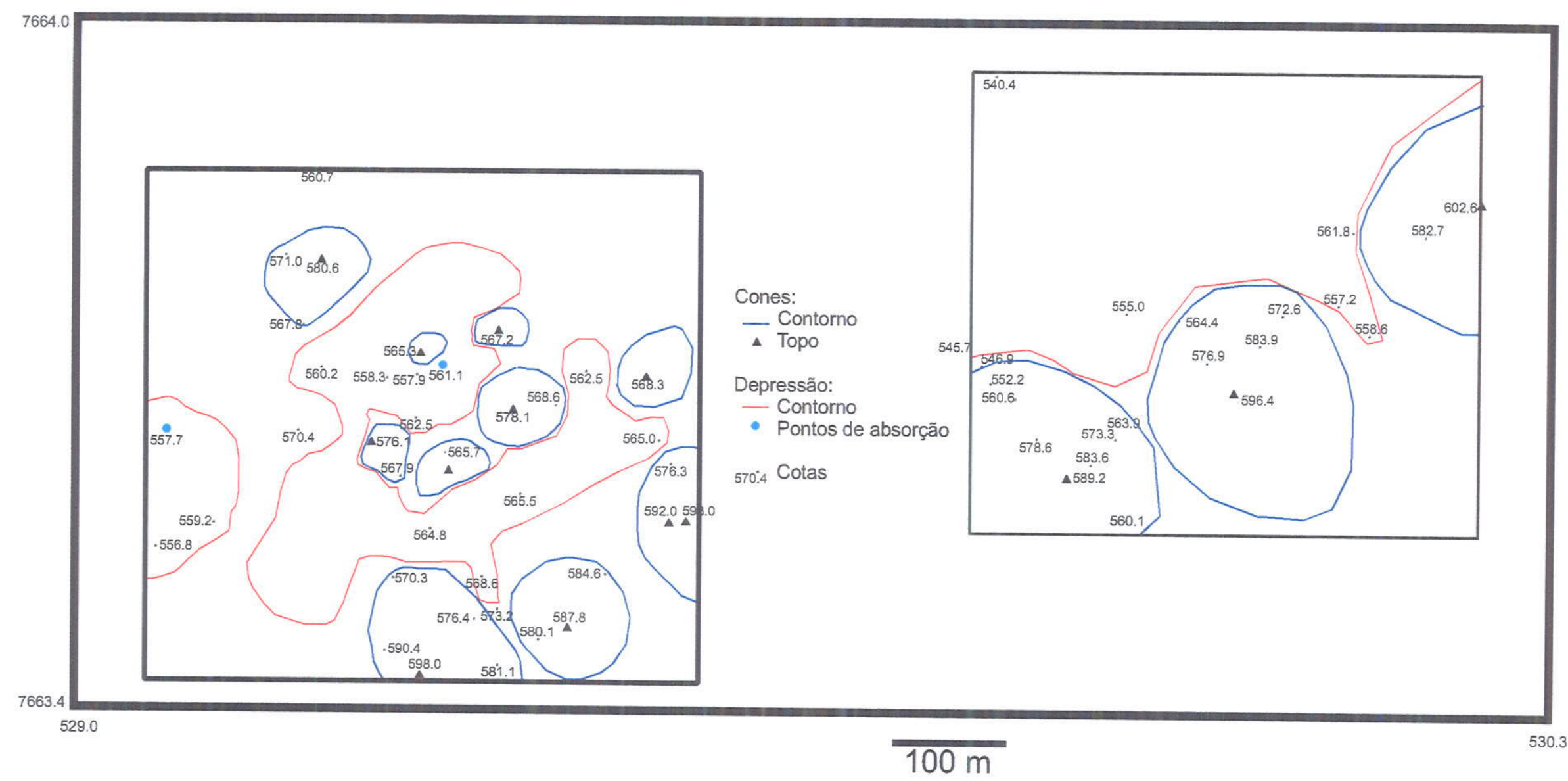

Figura 4.8: Área de detalhe no domínio CLCP (Área Rio Perdido), pontos 48 e 49. 

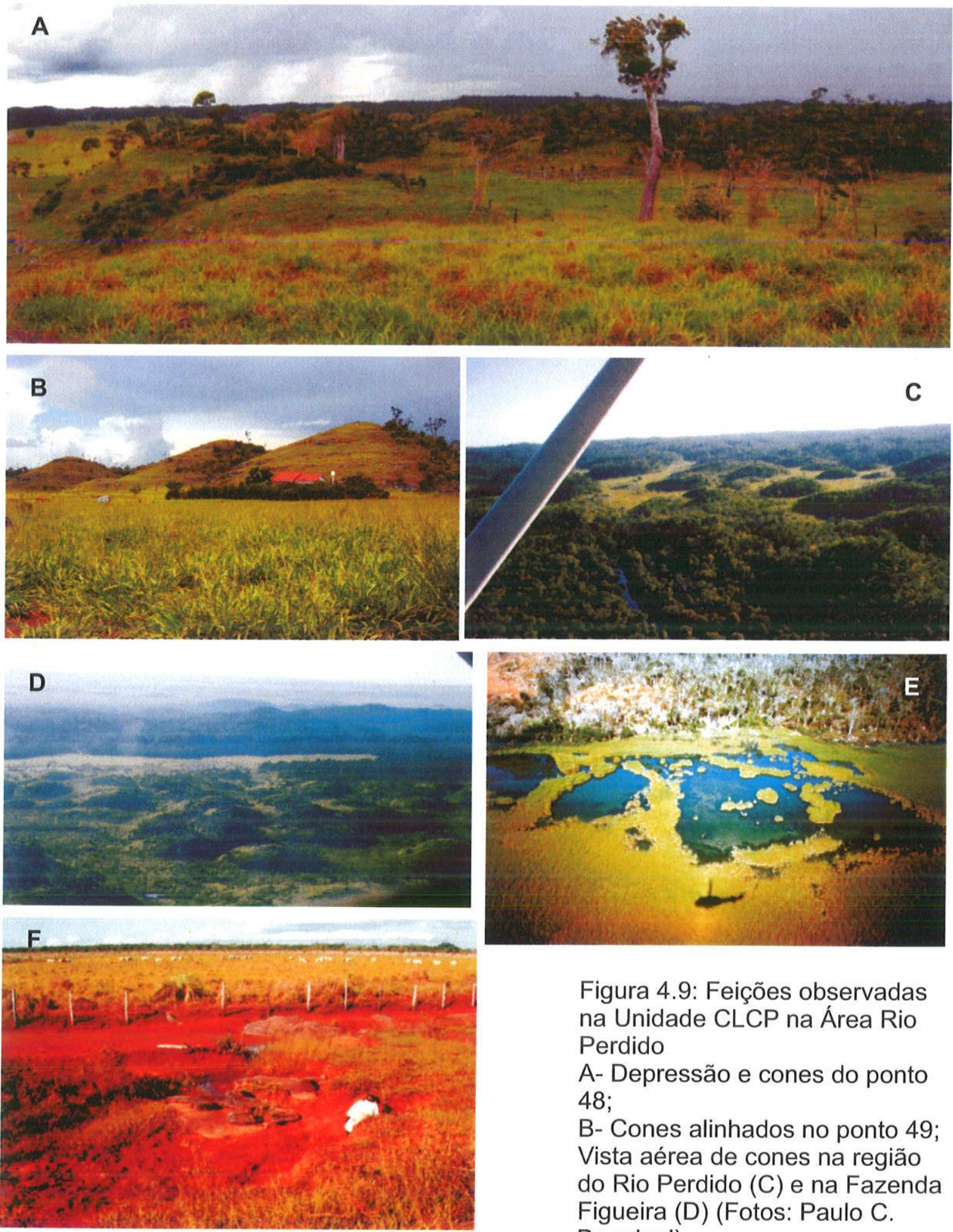

Figura 4.9: Feições observadas na Unidade CLCP na Área Rio Perdido

A- Depressão e cones do ponto 48;

B- Cones alinhados no ponto 49; Vista aérea de cones na região do Rio Perdido (C) e na Fazenda Figueira (D) (Fotos: Paulo C.

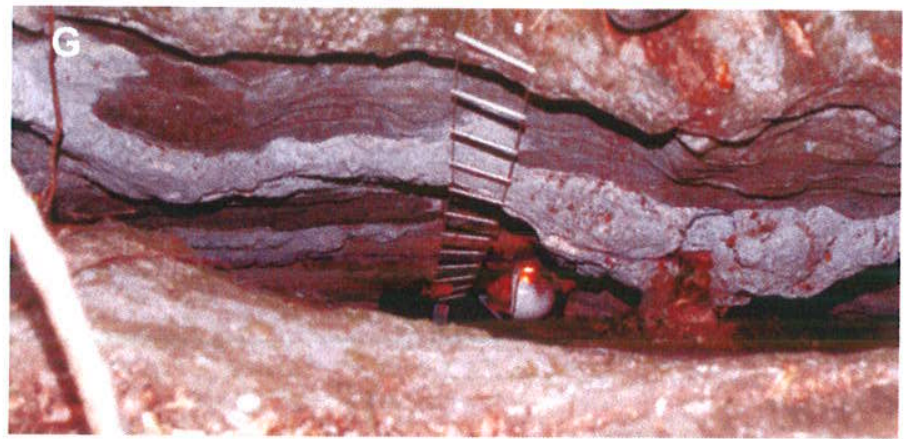
Boggiani);

E- Várzea nas nascente do Rio Perdido (Foto: Paulo C.

Boggiani);

F- Karren em epicarste com solo pouco espesso na região da Faz. Baía das Garças; G- Fenda de dissolução (abismo) próxima a Gruta da Pata. 


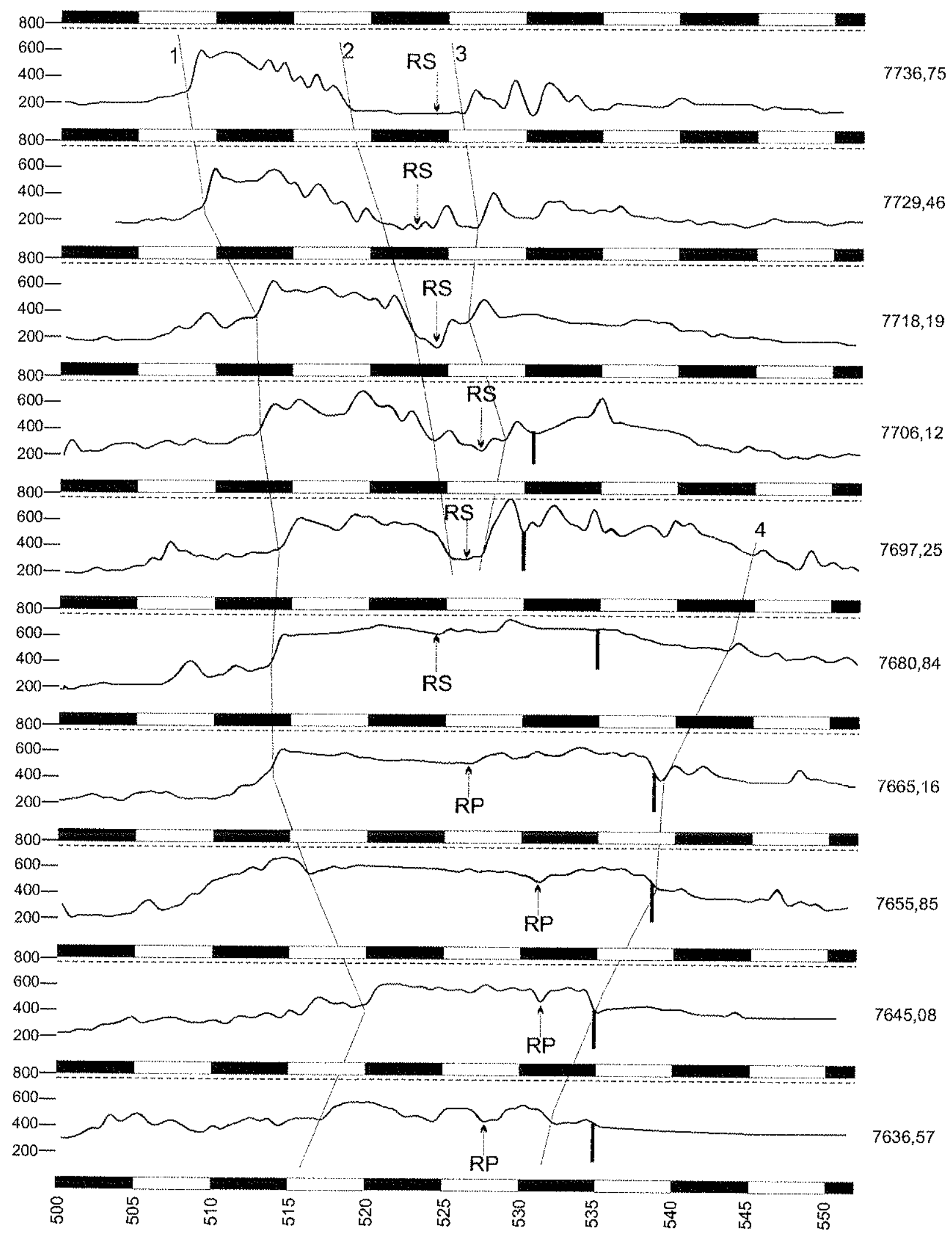

Figura 4.10: Perfis topográficos. Escala vertical exagerada; linha pontilhada indica 730 metros de altitude; linha escura vertical indica o limite entre os calcários e dolomitos; RS. Rio Salobra; RP-Rio Perdido; 1- Escarpa Oeste; 2 e 3-Vertentes oeste e leste do Vale do Rio Salobra; 4- Escarpa leste. 


\subsubsection{2. Área Rio Salobra}

Trata-se de um carste de recarga mista, dominantemente autogênica, caracterizado por carste labiríntico e carste poligonal, recortados por vales fluviais (Figura 4.6A e Anexo 4). Estes vales são formados por afluentes do Rio Salobra em maior ou menor grau de entalhamento, sendo alguns subterrâneos.

A estruturação deste setor segue um monoclinal que apresenta camadas de direção norte-sul e mergulhos de 10 a $20^{\circ}$ para leste (Anexos $5 \mathrm{a}$ e b, perfis A-A', D-D' e G-G'). A superficie definida pelo alinhamento dos topos dos morros segue aproximadamente o sentido de mergulho das camadas (Figura 4.10, perfis 7736,75; $7729,46 ; 7718,19)$. A superfície apresenta rugosidade de 1.0227 , maior do que na Area Rio Perdido, denotando maior dissecação do relevo na área do Rio Salobra.

O carste labiríntico é semelhante àquele descrito para área do Rio Perdido, porém ocorrendo apenas nos interflúvios (Figura 4.6A). Neste setor ocorre um padrão de drenagem dendrítica convergente em detrimento a presença do carste labiríntico e carste poligonal (Figura 4.6A). A drenagem segue de SW para NE (Figura 4.2A, $4.11 \mathrm{e}$ 4.12), condicionada pelo sistema de fraturas. Este sistema de fraturas também condiciona as fendas de dissolução.

O carste poligonal apresenta maior amplitude, com depressões mais profundas e com fundos côncavos, tendendo a morfologia de cockpit karst de White (1988). Cones também são comuns, porém em quantidade menor do que na Área Rio Perdido (Figura 4.12C). Contou-se cerca de $1400 \mathrm{em} 808 \mathrm{~km}^{2}$, fornecendo um densidade de cones (Dc) de 1.7 por $\mathrm{km}^{2}$ (Tabela 2.1). Atribui-se esta menor densidade de cones cársticos e a morfologia do tipo cockpit karst ao gradiente hidráulico maior neste setor em comparação a área do Rio Perdido. Na região de Morraria a Unidade CLCP é interrompida através do canyon do Córrego Serra (Figura 4.12E), pertencente à Unidade CPA. Na região de Morraria ocorre a parte mais estreita do Planalto da Bodoquena, com cerca de 11 quilômetros (Figura 4.12A e B).

As cavernas deste compartimento são relativamente comuns e de desenvolvimento maior do que as observadas na área do Rio Perdido. Seus padrões morfológicos predominantes são de condutos simples meandrantes (Capítulos 5.3.1 e 5.3.2). Estas cavernas representam a conexão entre a injeção alogênica da Zona de Transição (ZT) e o nível de base do setor, o Rio Salobra. Na Fazenda Califónia temos uma área de captação muito elevada composta de granitos (Unidade ZT), gerando águas agressivas, que percorrem as planícies da Unidade ZT (rochas terrígenas e dolomíticas) e alcançam os calcários da Unidade CLCP formando uma série de sumidouros (Figura 4.11). Dois 
destes sumidouros foram reconhecidos em fotos aéreas e se tratam das grutas Beija Flor (Ponto 3) e Califórnia (Ponto 9) (Figuras 4.11,5.5 e 5.6). As ressurgências destes pontos não foram localizadas, mas acredita-se que ocorrem próximo ao Rio Salobra. No Assentamento Guaicurus situação semelhante é observada e existem pelo menos 8 cavernas reliquiares de antigos sistemas de injeção alogênica, muitas delas antigos sumidouros, notadamente as grutas Guaicurus (Ponto 36) e Haroldo (Ponto 96) (Figura 4.13). Existe um sumidouro descrito por Imperio \& Pezzolato (1991) como MS-06, não visitado em campo, que forma um afluente do Rio Salobra (Figura 4.13). Esta captação alogênica percorre trechos subterrâneos que ressurgem como afluentes do Rio Salobra, na vertente oeste do seu vale.

\subsubsection{Canyons e planicies aluviais - CPA}

É uma unidade onde dominam processos fluviais sobre rochas carbonáticas e trechos onde o entalhamento fluvial atingiu o substrato não carbonático (Figuras 4.2, 4.6, Anexos $5 a$ e $b$, perfil D-D'). Corresponde principalmente ao vale do Rio Salobra e seus afluentes (Figura 4.6A).

Esta captação alogênica percorre trechos subterrâneos na unidade CLCP que ressurgem como afluentes do Rio Salobra, na vertente oeste do seu vale (Figuras $4.11 \mathrm{e}$ 4.12). O Rio Salobra representa um sistema fluvial alimentado pela circulação cárstica, tanto de origem mista, das unidades a oeste do vale, como de origem alogênica.

Nas nascentes do Rio Salobra dominam vales estreitos, tipo canyons (Figuras 4.12D, 4.13, 4.14A, B e C) que se alargam formando planícies de agradação, com fundo plano e cobertura sedimentar (planície aluvial) à medida que o rio atinge o seu médio e baixo curso (Figuras 4.6A e 4.14E). Segue de sul para norte, condicionado pela direção das camadas.

As vertentes caracterizam-se pela presença de feições cársticas, na transição com a unidade CLCP, tais como nascentes e ressurgências (Figuras 4.6E, 4.14D e E). Tufas estão sendo depositadas ao longo do Rio Salobra e seus afluentes, mas sem expressão em área para demarcação nesta escala.

Na região de Morraria o Córrego Serra é o afluente do Rio Salobra mais entalhado, alcançando até $300 \mathrm{~m}$ de profundidade (Figuras 4.12A, B C e D). 


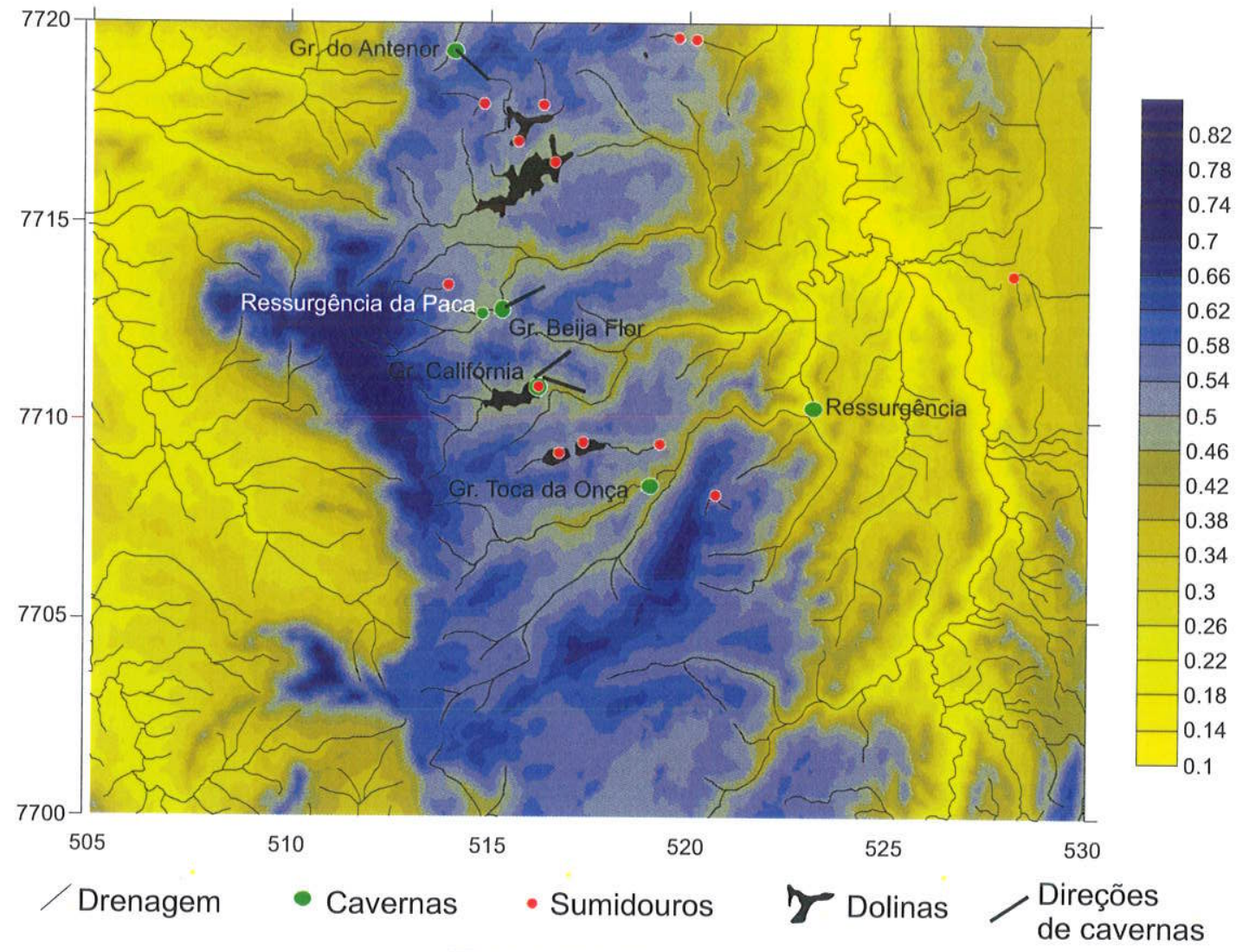

A

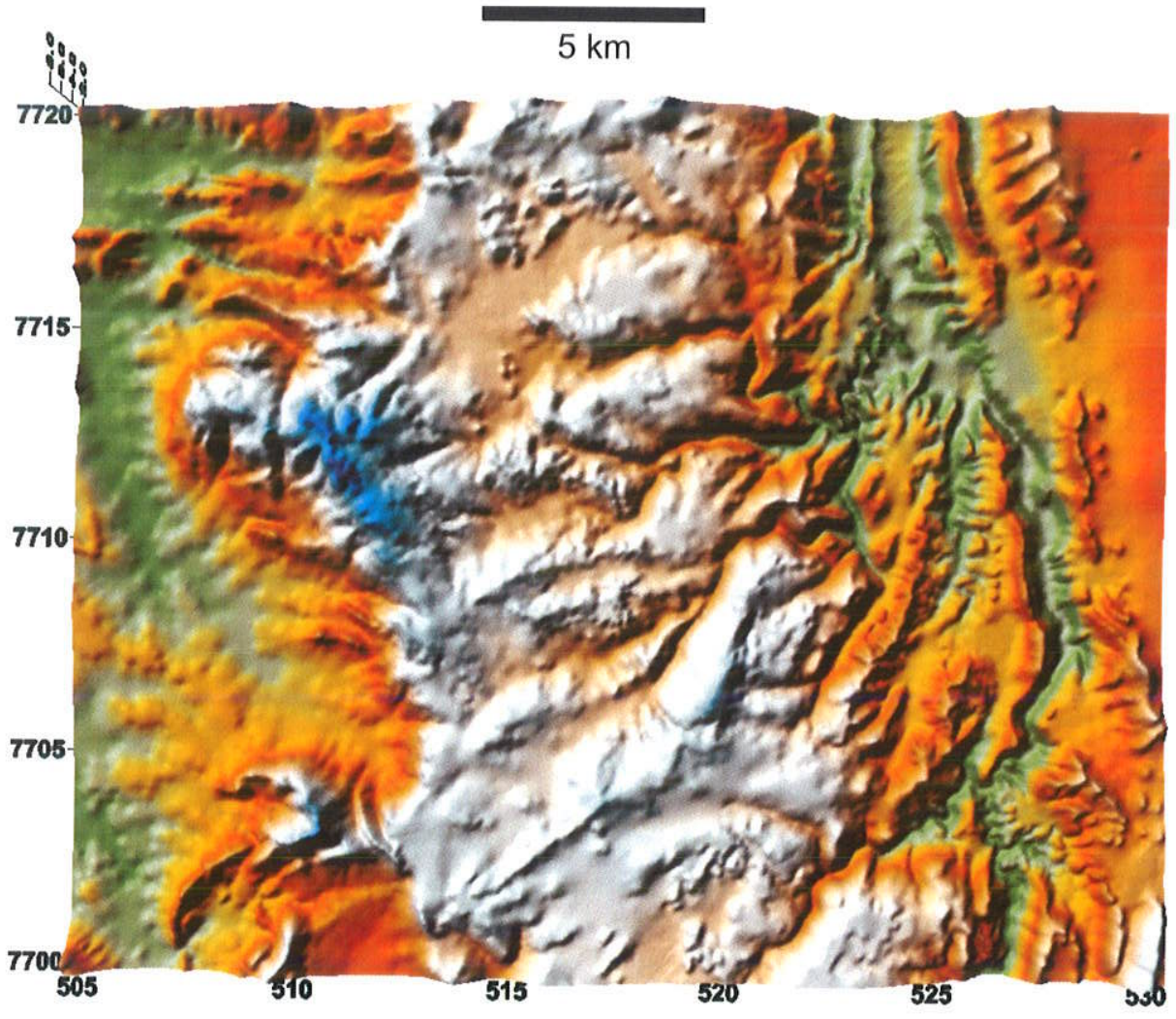

Figura 4.11: Hipsometria com feições cársticas $(A)$ e modelo digital de terreno $(B)$ da unidade CLCP na área Rio Salobra, na região da Faz. Califórnia. 

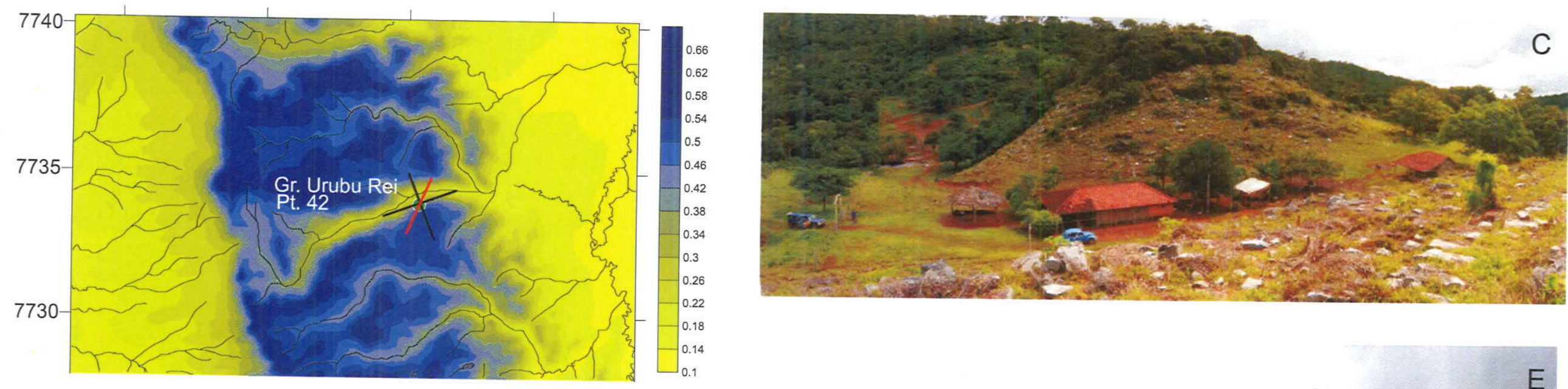

A

505

510

515

520

Drenagem Cavernas / Direções

Fratura no

interior da Gr.

Urubu Rei
(nascente
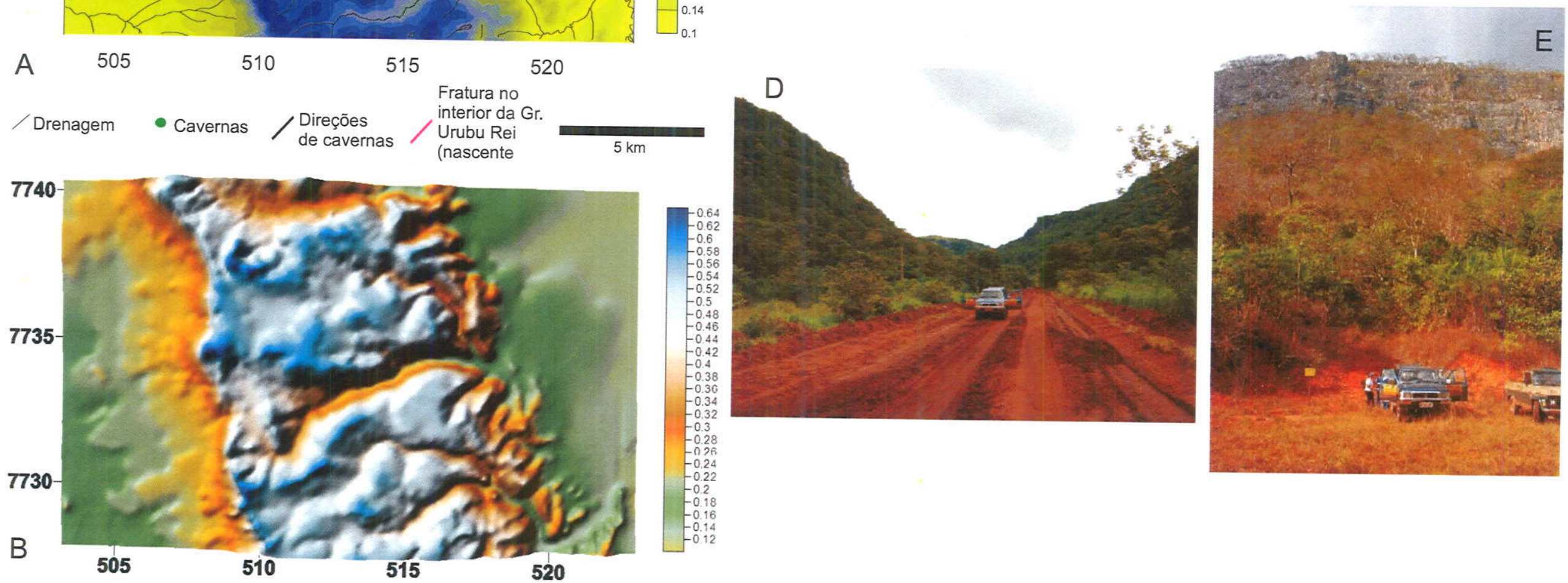

Figura 4.12: A- Hipsometria com feições cársticas; B- Modelo digital de terreno; C- Fotografia de cones cársticos da unidade CLCP na área
Rio Salobra, na região de Morraria; D- Vista do Córrego Serra, Rio Salobra, na região de Morraria; D- Vista do Córrego Serra, mostrando o vale fechado (canyon), na Unidade CPA; E- Vertentes escarpadas do Córrego Serra onde situa-se a entrada da gruta Urubu Rei, na Unidade CPA (Ponto 19). 


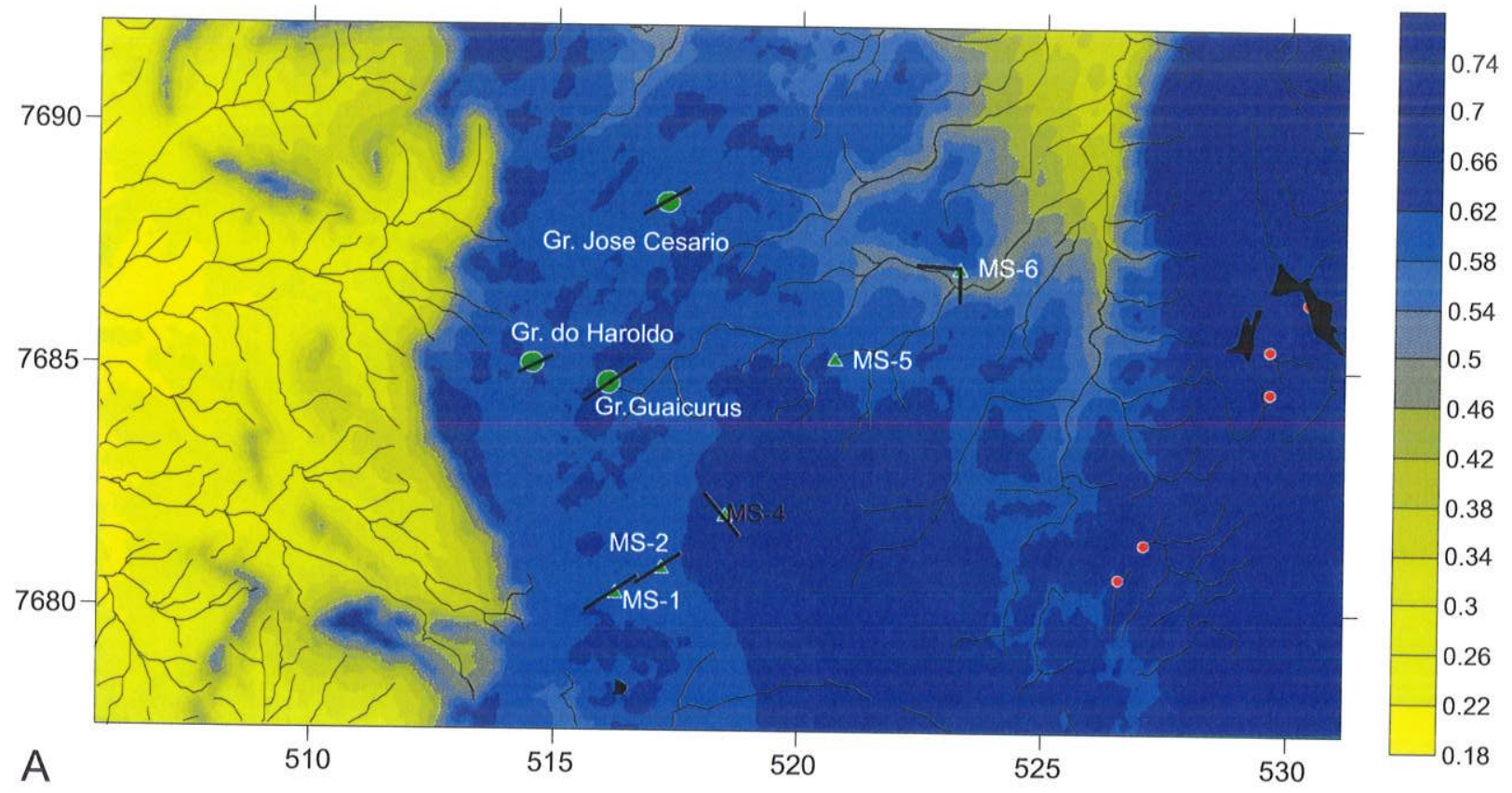

MS-1 a 6 :

Drenagem $\bullet$ Cavernas $\begin{gathered}\text { cavernas } \\ \text { descritas por }\end{gathered} *$ Sumidouros 2 Dolinas $/$ Direções
de cavernas Imperio \&

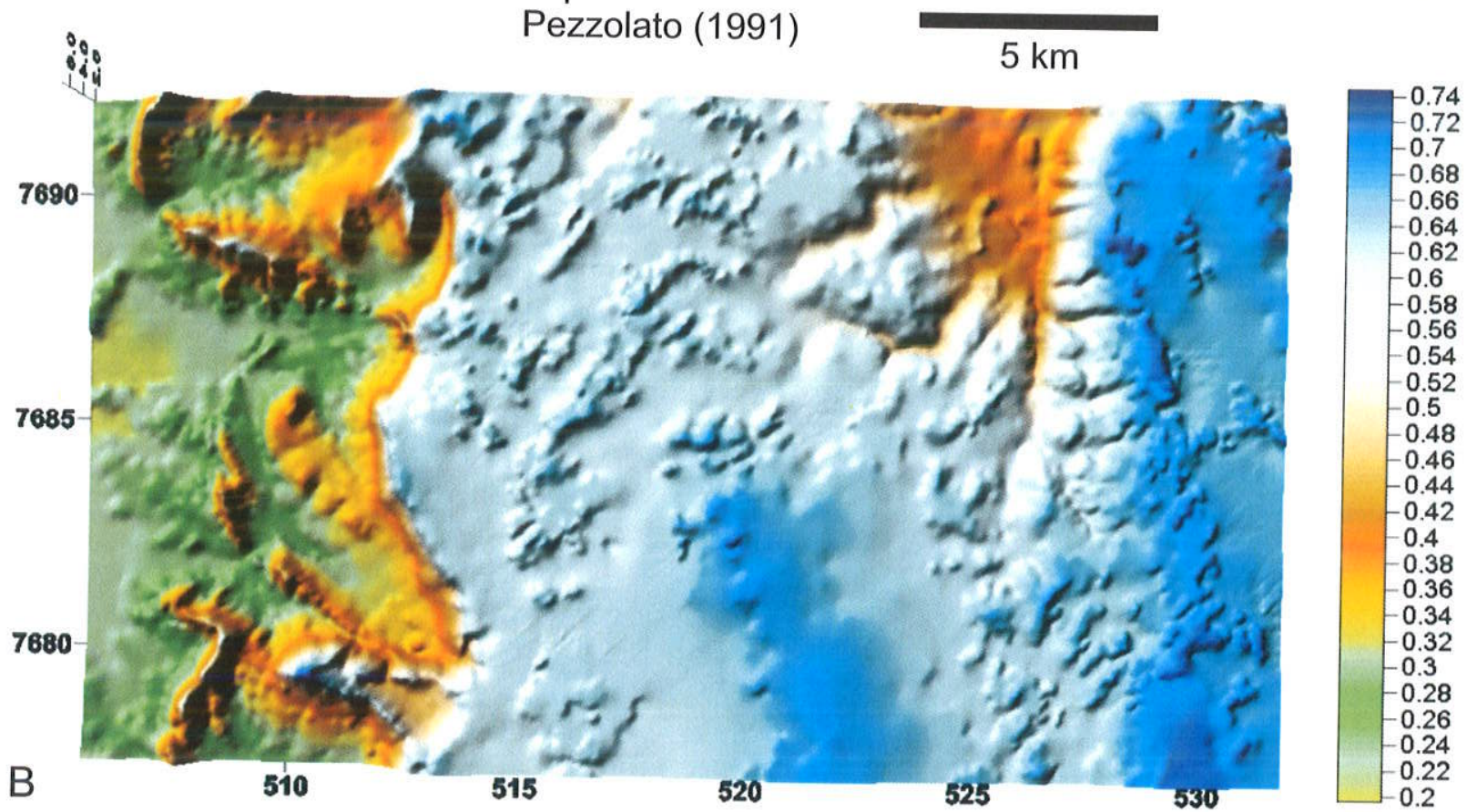

Figura 4.13: Hipsometria com feições cársticas (A) e modelo digital de terreno (B) na região do Assentamento Guaicurus. 
A
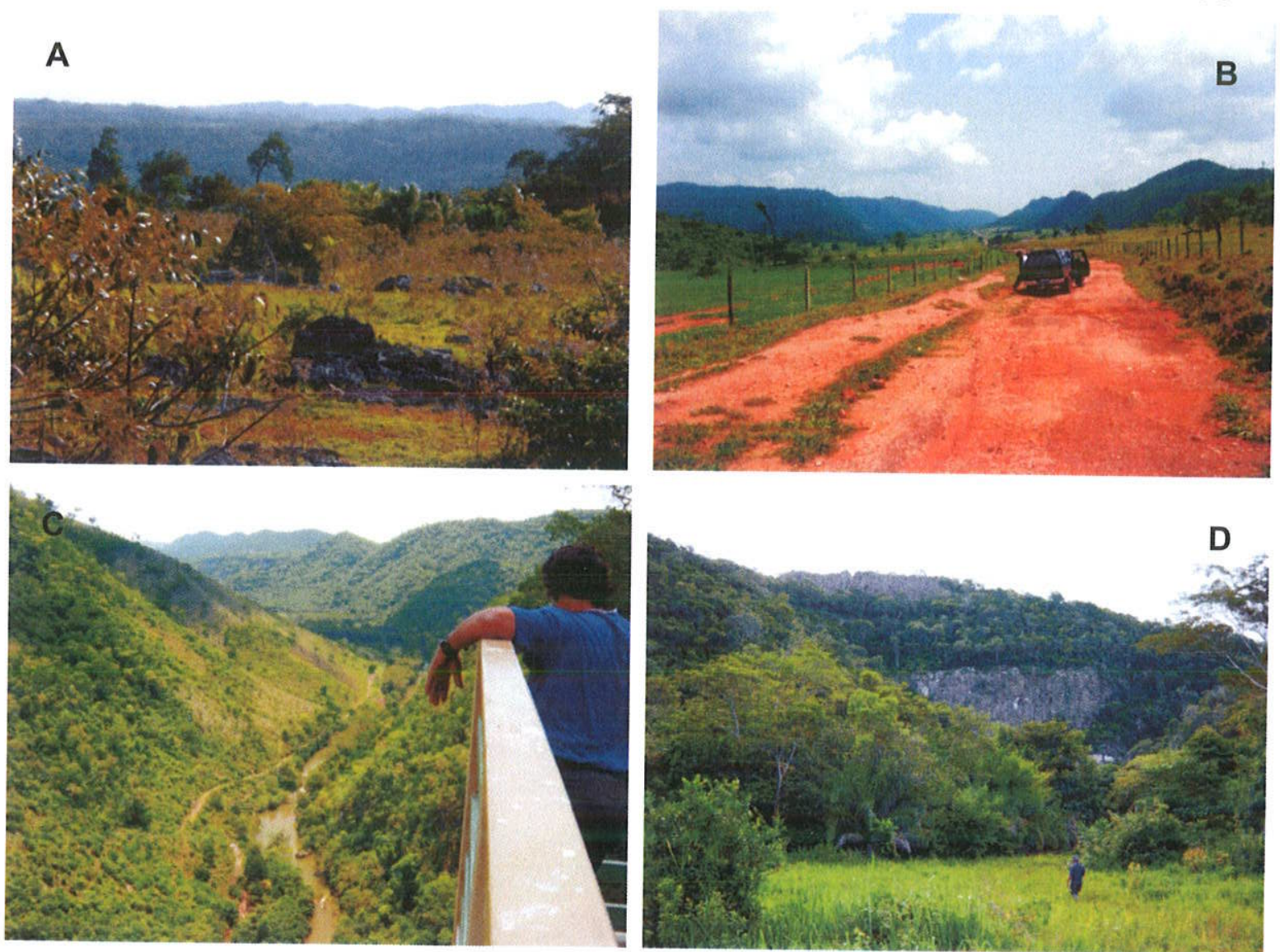

3

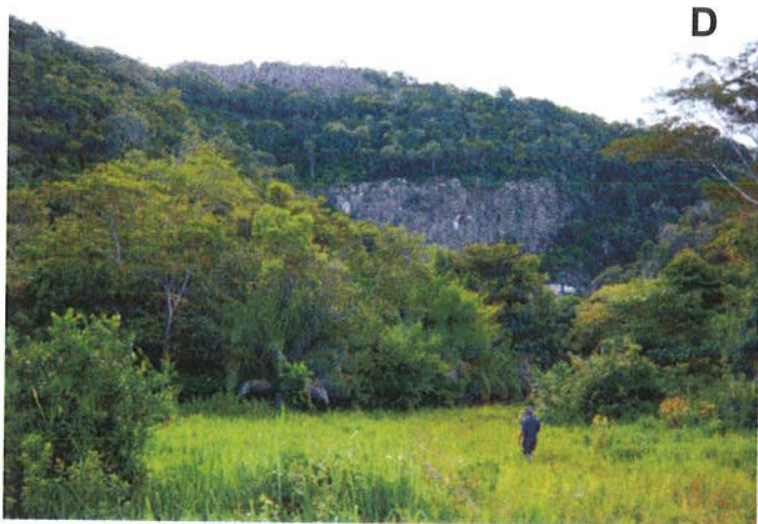

E

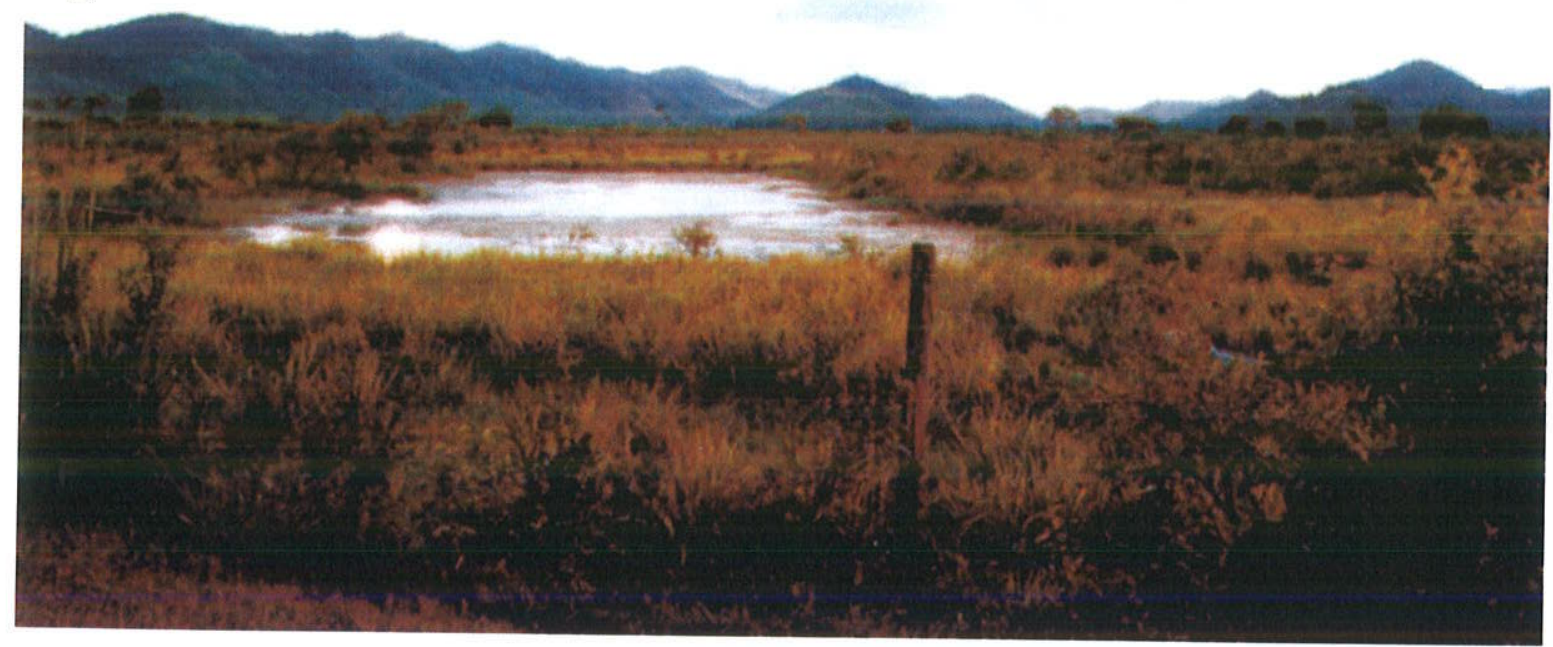

Figura 4.14: Unidade CPA. A- Canyon do Rio Salobra visto a oeste a partir do ponto 142, situado na superfície aplainada da Unidade CLCP; B- Canyon de afluente do Rio Salobra, visto a norte a partir do ponto 161; Rio Salobra: CCanyon na Faz. Boca da Onça (ponto 164), D- Vertentes escarpadas na Faz. Remanso (ponto 76), E- Planície no baixo curso, entre Morraria e Bodoquena. 


\subsubsection{Zona de transição - ZT}

Esta unidade ocorre formando uma faixa irregular na borda oeste do Planalto da Bodoquena (Figura 4.4 e Anexo 4). É caracterizada pela zona de contato entre rochas carbonáticas e não carbonáticas (Anexos $5 \mathrm{a}$ e b). De oeste para leste ocorrem planícies (Figura 4.15B) sobre o substrato não carbonático entre morros testemunhos carbonáticos $e$, conforme o aumento gradativo da espessura da cobertura carbonática, ocorre a transição para a unidade CLCP (Figuras 4.4, 4.6, 4.10, perfis 7706,12 e 7697,25 , Anexos 4 e 5b, perfil D-D'). Esta transição é marcada por sumidouros às vezes associados a poljes de contato ou vales cegos (Figuras 4.11 e 4.13). De forma isolada ocorrem dolinas e não se observam cavernas. Seu relevo pouco acidentado pode ser quantificado pela rugosidade de 1.0013 (Tabela 4.1).

Inclui áreas de captação alogênica em relação ao sistema cárstico a leste (Figura 4.11, Anexos $5 a$ e b, perfil $\left.D_{-} D^{\prime}\right)$. Na porção norte do planalto, já na bacia do Rio Salobra, as planícies da borda oeste quando constituídas de rochas terrigenas atuam como áreas de captação alogênica sendo comuns sumidouros ativos e inativos (Figuras 4.15A, C, Anexos 5a e b, perfil D-D'). Esta captação alogênica é efeito da presença de rochas terrígenas e do próprio entalhamento do vale do Rio Salobra e seus afluentes. Exemplos típicos destas feições ocorrem na Faz. Califórnia e no Assentamento Guaicurus (Figuras 4.11, 4.13 e 4.15). Poucos rios escoam para oeste, como é o caso do Rio Aquidaban, na Faz. Baía das Garças, que se torna subterrâneo em um sumidouro (Ponto 92, Figuras $4.15 \mathrm{C}$ e D), e ressurge alguns metros à frente, depositando tufas em cachoeira sobre rochas graníticas do embasamento (Figura 4.18C). 

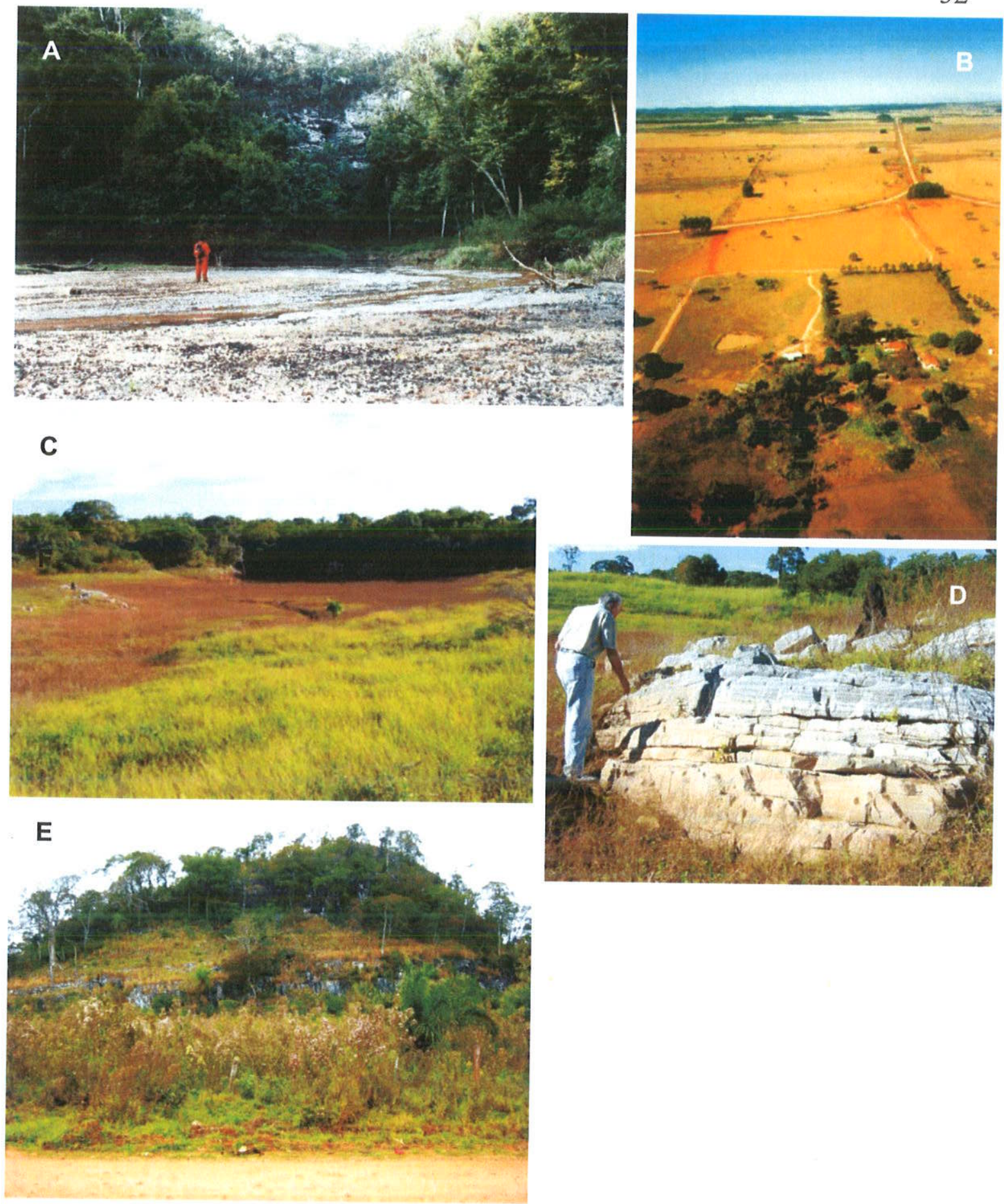

Figura 4.15: Unidade ZT. A- Sumidouro da Gruta Califórnia (Ponto 9) na transição para a Unidade CLCP; B- Vista aérea de planícies na Faz. Baía das Garças (Ponto 92); C- Sumidouro na Faz. Baía das Garças (Ponto 92); D- Afloramento de calcário estratificado no sumidouro do Ponto 92; E- Cone cárstico isolado da Unidade CLCP, onde está situada a entrada da Gruta do Haroldo (Ponto 96). Foto B: Paulo C. Boggiani. 


\subsubsection{Planícies cársticas com morros residuais}

Esta unidade é subdividida em dois compartimentos. O setor leste, no domínio dos dolomitos, geralmente ocorre em cotas inferiores a $500 \mathrm{~m}$, ocupando parte da Depressão do Rio Miranda (Figuras 4.4, 4.6B, Anexos 4 e 5a) e o setor oeste, no domínio dos calcários, por sua vez, apresenta-se em cotas superiores a $500 \mathrm{~m}$, formando junto com as unidades CLCP e ZT o Planalto da Bodoquena (Figura 4.4, Anexos 4 e $5 a$ ). Em ambos setores a morfologia típica corresponde a planícies com morros residuais.

\subsubsection{1. Área dos dolomitos}

Neste compartimento as planicies representam superficies suavemente onduladas (Figuras 4.16A, B, C e 5.9) cobertas por solo residual avermelhado espesso (cerca de $10 \mathrm{~m}$ ), indicando um epicarste mais profundo do que na área dos calcários (Figuras $4.16 \mathrm{D}$ e E). São freqüentes dolinas de subsidência lenta no solo (nas planicies) às vezes expondo karren arredondados do epicarste em seus fundos (Figura 4.16E). As maiores chegam até $70 \mathrm{~m}$ de diâmetro e $10 \mathrm{~m}$ de profundidade ( $P / D=0.14$ ) (Figura 4.16E). De forma isolada ocorre uma rede de drenagem superficial com baixa densidade. Este escoamento superficial está associado às nascentes cársticas as quais ocorre principalmente na margem oeste e também no interior da unidade (Figuras 4.16F e G). A recarga hídrica desta unidade é realizada tanto pela captação autogênica, sobre sua superficie, como de forma subterrânea com fluxo originado na Unidade CLCP.

Os morros residuais possuem amplitude altimétrica variando entre 30 e $220 \mathrm{~m}$, vertentes comumente íngremes, com inclinação variando entre $7-33^{\circ}$, em 15 morros medidos na região da Gruta Lago Azul, e cobertura de solo residual avermelhado rico em fragmentos de quartzo, calcário e calcário silicificado (Figura 4.16D). Sua forma varia entre cones isolados, agrupamentos de cones alinhados (Figura 4.16C) e cristas. Este alinhamento preferencial acompanha a direção média de acamamento de NS/34E, na região da Gruta Lago Azul (Figura 5.12). Os morros representam $8 \%$ da área total e a razão entre morros e planícies ( $\mathrm{Rmp}$ ) é de 0.08 , o que condiciona também a baixa rugosidade 1.0022 (Tabela 4.1). Contou-se 368 morros fornecendo uma densidade de morros $(\mathrm{Dm})$ de 0.17 morros $/ \mathrm{km}^{2}$, valor baixo quando comparado com a Unidade CLCP (Tabela 4.1).

Este compartimento abriga a maioria das cavernas da Serra da Bodoquena. A maioria destas correspondem a salöes de abatimento que acompanham planos de fraturas e acamamento, com raros trechos de condutos originais. Localizam-se sempre 
nos morros residuais. Parte destes salões de abatimento encontram-se abaixo do nivel d'água, com evidências de feições vadosas submersas, como é o caso das grutas Mimoso, Anhumas e Lago Azul, conforme será discutido no Capítulo 5.

Além dos salões de abatimento, ocorrem cavernas com morfologia em rede anastomosada, associadas a intercalações locais de calcários (p.ex. Gruta Pitangueiras).

\subsubsection{2. Área dos calcários}

Este compartimento localiza-se entre as áreas Rio Perdido e Rio Salobra da Unidade CLCP (Figura 4.4, Anexo 4). Neste compartimento, em contraste com as áreas dolomíticas, as planícies, também suavemente onduladas, possuem cobertura de solo pouco espessa (1-2 $\mathrm{m})$, com epicarste raso sem a incidência de dolinas e uma rede de drenagem superficial incipiente. Sua recarga hídrica é predominantemente de natureza autogênica com contribuição alogênica da unidade $Z T$.

Os morros residuais possuem amplitude altimétrica de cerca de $100 \mathrm{~m}$ e representam fragmentos da Unidade CLCP, pois correspondem a cones cársticos associados a depressões poligonais e fendas de dissolução (Anexo 4). Os morros representam $21 \%$ da área total e a razão entre morros e planicies (Rmp) é de 0.26 (Tabela 4.1). A rugosidade de 1.0013, semelhante à obtida nos dolomitos confirma uma caracteristica geral da unidade PCMR (Tabela 4.1). Contou-se 180 morros o que fornece uma densidade de morros $(\mathrm{Dm})$ de 0.57 morros $/ \mathrm{km}^{2}$ (Tabela 4.1). Neste setor não foram verificadas cavernas. 
A
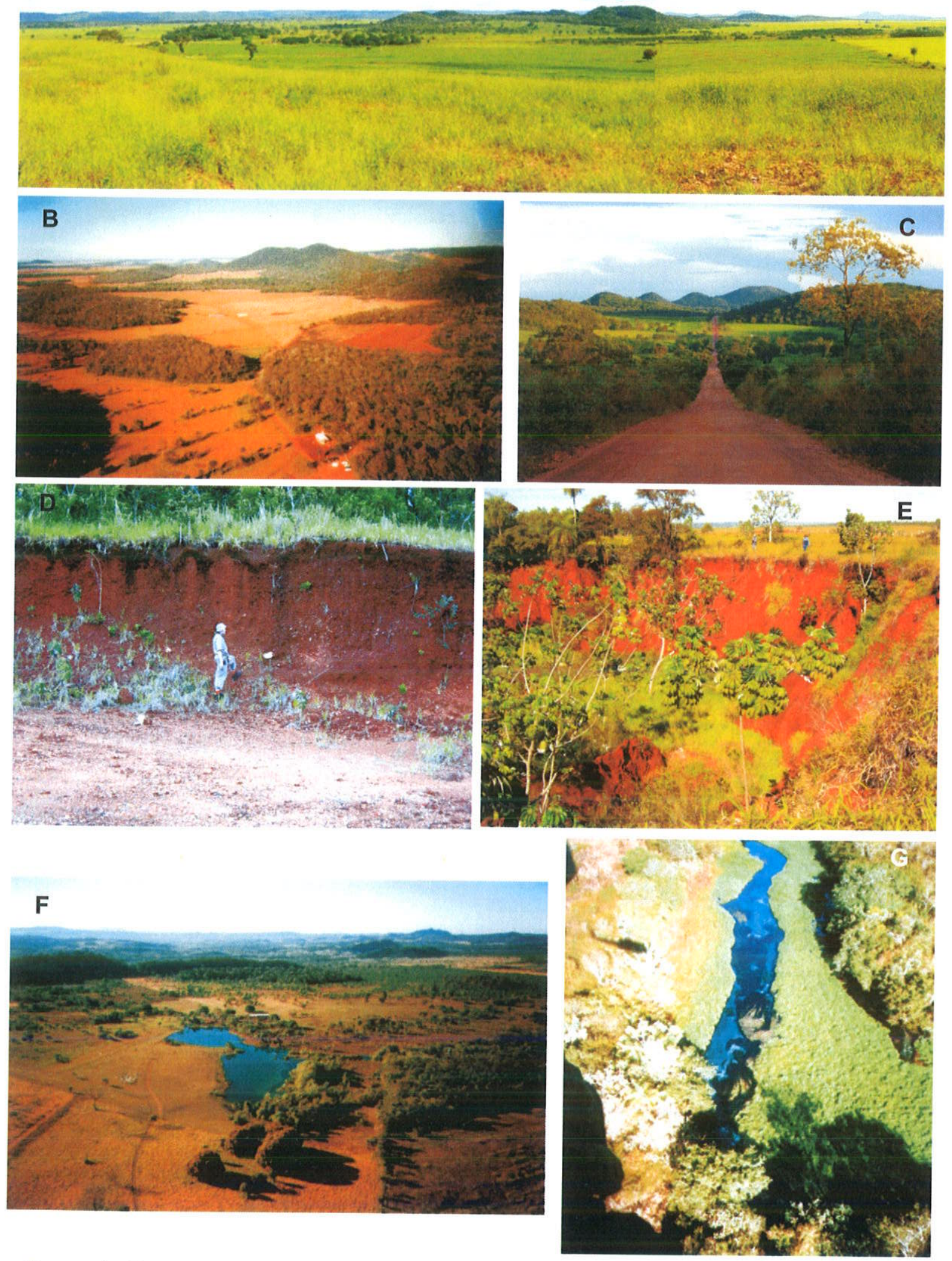

Figura 4.16: Unidade PCMR. A- Morros residuais e planícies, em vista do ponto 77 (para norte). B- Vista aérea de morros e planícies; C- Cones alinhados na região de

Bonito; D- Solo residual com blocos de quartzo (Ponto 53); E- Dolina em solo residual avermelhado no Ponto 119. F- Vista aérea do lago da nascente da CeitaCorê (Ponto 130). G- Vista aérea do Rio Sucuri. Fotos B, F e G: Paulo C. Boggiani. 


\subsubsection{Planícies com coberturas de tufas - PCT}

Depósitos de tufas representam feições construtivas no quadro geral de erosão em sistemas cársticos (Ford \& Williams, 1989). Na Serra da Bodoquena há deposição atual ou depósitos antigos de tufas. Sua ocorrência está associada de modo geral à rede de drenagem, formando uma unidade morfológica. Aqui é adotado o termo "tufa" bem caracterizado por Ford \& Pedley (1996), numa extensa revisão destes depósitos por todo o mundo. Segundo estes autores a tufa é o "produto da precipitação de carbonatos em águas frias (não termais) e que tipicamente contém restos de micro- ou macrófitas, invertebrados e bactérias". O termo travertino é restrito a depósitos termais e o termo "tufo" a rochas vulcânicas piroclásticas (Ford \& Pedley, 1996).

Representam, além de uma feição morfológica importante (Figura 4.4 e Anexo 4), uma unidade geológica expressiva (Anexo 5a). Também é um bem mineral abundante na região comercializada em alguns locais devido a fácil extração (Figura 4.18H) como corretivo de solo na agricultura.

Dentre as tufas da Serra da Bodoquena Boggiani et al. (2002) reconhece dois tipos principais: as represas e cachoeiras de tufas e as micritas inconsolidadas (calcários pulverulentos), que correspondem respectivamente, a tufas atuais e antigas. Estes dois tipos de tufas foram caracterizados neste trabalho como depósitos de rios (deposição ativa) e micritas inconsolidadas (calcários pulverulentos).

\subsubsection{Depósitos de rios (deposição ativa)}

A deposição de tufas ocorre atualmente ao longo da maioria dos rios da região, (Figura 4.17) como, por exemplo, nos rios Formoso, Peixe, Prata e Campina na unidade PCMR; nos rios Perdido e Salobra, na Unidade CLCP. Esta deposição ocorre praticamente em todos os rios ou fluxos de água esporádicos da região, cobrindo as margens e o leito, com material rochoso e vegetal (Figuras $4.17 \mathrm{~A}$ e $\mathrm{B}$ ), formando represas e cachoeiras ao longo do vale fluvial (Figuras $4.17 \mathrm{G} \mathrm{e} \mathrm{H}$ ), porém não é uma unidade morfológica representável em escala 1:60.000. Em um ponto do Rio Formoso observaram-se estruturas verticais, como domos e colunas, que se assemelham a bioconstruções, de tamanho centimétrico a decimétrico mais próximo a nascente, e métrico a jusante (Figuras 4.17B, $C$ e D). Em seção estas bioconstruções são laminadas com pequenos tubos verticais, atribuídos a atividade de algas (Figura 4.17F). O sedimento presente nos fundos dos rios são compostos de partículas carbonáticas, conchas (incrustadas ou näo), raros seixos de rochas (incrustados ou não), e muitas carapaças incrustadas de algas caráceas, com desde pouco a nenhum material 
terrígeno (Figura 4.17E). Formam represas decimétricas a métricas, muitas vezes formando patamares que desmoronam ocasionalmente por seu próprio peso. As represas ocorrem em rios que possuem um gradiente de baixo a moderado, pois quando ele é muito alto ocorrem depósitos diretamente sobre o leito dos fluxos de água, como no Rio Aquidaban (Figura 4.18C). Um caso interessante é a ressurgência da Gruta Urubu-Rei (Ponto 42), situada na encosta do Córrego Serra (Planalto da Bodoquena), $150 \mathrm{~m}$ acima deste, onde ocorrem represas de tufas ao longo de toda a drenagem a partir da nascente, ativas apenas nos periodos de cheia ou mais úmidos (Figura 4.18D). Ocorrem também na forma de terraços antigos e em cachoeiras e leitos fluviais abandonados, como observados no Rio Aquidaban e no Rio Mimoso (Figura 4.18A). É comum a presença de impressōes de folhas e raizes.

As tufas são compostas essencialmente de calcita, com baixo teor de dolomita $e$ um pouco de impurezas, como evidenciado por uma análise de amostra do córrego que nasce na Gruta Urubu Rei (Ponto 19), que apresenta uma proporção calcita-dolomitaimpurezas de $92,42-3,73-3,85$. Atribui-se a presença de dolomita a fragmentos rochosos.

\subsubsection{Micritas inconsolidadas (calcários pulverulentos)}

Os depósitos antigos de tufas possuem ampla distribuição pela Serra da Bodoquena (Figura 4.4. e Anexo 4). Formam coberturas de micritas inconsolidadas ricas em restos vegetais, gastrópodes (Figura 4.18F) e carapaças de algas (Figura 4.18G) atribuidas ao Quaternário (Boggiani et al., 2002) principalmente na Unidade PCMR tanto no domínio dos calcários como nos dolomitos (Figura 4.4, Anexos 4 e 5a). Encontram-se nas planícies, ao longo das margens dos rios Formoso, Perdido, Campina e Prata, e afluentes, nas unidades CLCP e PCMR (Figura 4.4. e Anexo 4).

Representam depósitos de tufa antiga associados ao desenvolvimento de antigas regiões alagadas ou de leitos de rios abandonados (Boggiani et al., 2002), restando apenas alguns pontos ainda com deposição São depósitos estratificados com conchas de gastrópodes e fragmentos vegetais. Boas exposições são encontradas em pedreiras próximas à cidade de Bonito, como a pedreira "Calcário Xaraiés" (Ponto 87), que explora estas tufas para corretivos de solo. Nesta pedreira a tufa possui no minimo $6 \mathrm{~m}$ de espessura (Figura 4.18E). Na região do Assentamento Campina (Bodoquena) constatou-se a ocorrência destes depósitos (Ponto 157), em uma planicie, associada ao Córrego Campina, com no mínimo $2 \mathrm{~m}$ de espessura, e presença de gastrópodes e restos de algas (Figuras $4.18 \mathrm{~B} \mathrm{e} \mathrm{H}$ ). 
É uma unidade morfológica com, no mínimo, $275 \mathrm{~km}^{2}$ de área (Tabela 4.1), conforme demarcação obtida em fotografias aéreas em escala 1:60.000 (Figura 4.4 e Anexo 4). Deste total, pelo menos $240 \mathrm{~km}^{2}$ correspondem aos depósitos sobre a Unidade PCMR e $35 \mathrm{~km}^{2}$ quando sobre a Unidade CLCP (Tabela 4.1).

Quando sobre a Unidade CLCP, os depósitos de tufas apresentam uma seqüência de represas justapostas, secas na superficie dos depósitos, observadas em fotografias aéreas com uma textura de linhas em arcos de contornos irregulares e sinuosos (Figuras 4.19) que indicam a presença e a direção de fluxo no ambiente de deposição. Alguns destes depósitos são, atualmente, regiões de brejos, podendo ainda estar ativos, mas com volume de água muito menor do que na época de formação dos depósitos antigos. Em alguns locais a estrada Bonito - Faz. Baia das Garças corta estes depósitos, como no ponto 93 , onde observa-se uma espessura de pelo menos $4 \mathrm{~m}$ (Figura 4.19). Também foram observadas no sumidouro do Rio Perdido (Ponto 22) na forma de terraços. Em área são bastante extensos, porém um pouco menores que os depósitos das planícies, com pouca espessura.

Estas tufas são compostas essencialmente de calcita, com baixo teor de dolomita e um pouco de impurezas, como evidenciado por uma análise de amostra de terraço do Rio Perdido (Ponto 22), que apresenta uma proporção calcita-dolomita-impurezas de $90,52-1,84-7,64$. Atribui-se a presença de dolomita a fragmentos rochosos.

\subsubsection{Idade e gênese das tufas}

As tufas da Serra da Bodoquena são formadas pela deposição de carbonatos, por ação biológica em águas ricas em bicarbonato (Boggiani \& Coimbra, 1995) originados pela dissolução dos calcários do Grupo Corumbá, em áreas cársticas.

No caso dos depósitos antigos este fluxo deve ter sido lento dado o baixo gradiente e conseqüentemente a pequena altura das represas. Parecem estar associadas a uma fase mais úmida, onde com a subida do nível d'água algumas nascentes seriam reativadas.

As tentativas de datação destas tufas encontraram problemas pelo método ${ }^{14} \mathrm{C}$ relacionados ao carbono herdado das rochas do substrato através das águas (Boggiani et al., 2002) e pelo método U/Th por ser um sistema aberto (Ribeiro et al., 2001). Mesmo assim, algumas idades foram obtidas pelo método ${ }^{14} \mathrm{C}$ em depósitos: entre 2130 e 3410 anos A.P. no Rio Aquidaban, no Planalto da Bodoquena (Boggiani et al., 2002) e 3900 
anos A.P. em tufas do Rio Miranda, na planície do Pantanal Matogrossense (Ribeiro et al., 2001).

Depósitos de tufas antigas ocorrem em alguns locais no Brasil, porém tufas ativas não são muito comuns. Acreditamos que a deposição destas tufas, como conseqüência da surgência de água subterrânea supersaturada em relação ao $\mathrm{CaCO}_{3}$, é favorecida na Serra da Bodoquena pela predominância de águas autogênicas, quase não havendo áreas de captação alogênicas significativas. As poucas áreas de captação alogênica, situadas principalmente na borda oeste do planalto (Unidade ZT) percorrem um longo trecho nos calcários se enriquecendo assim de carbonatos em solução. 

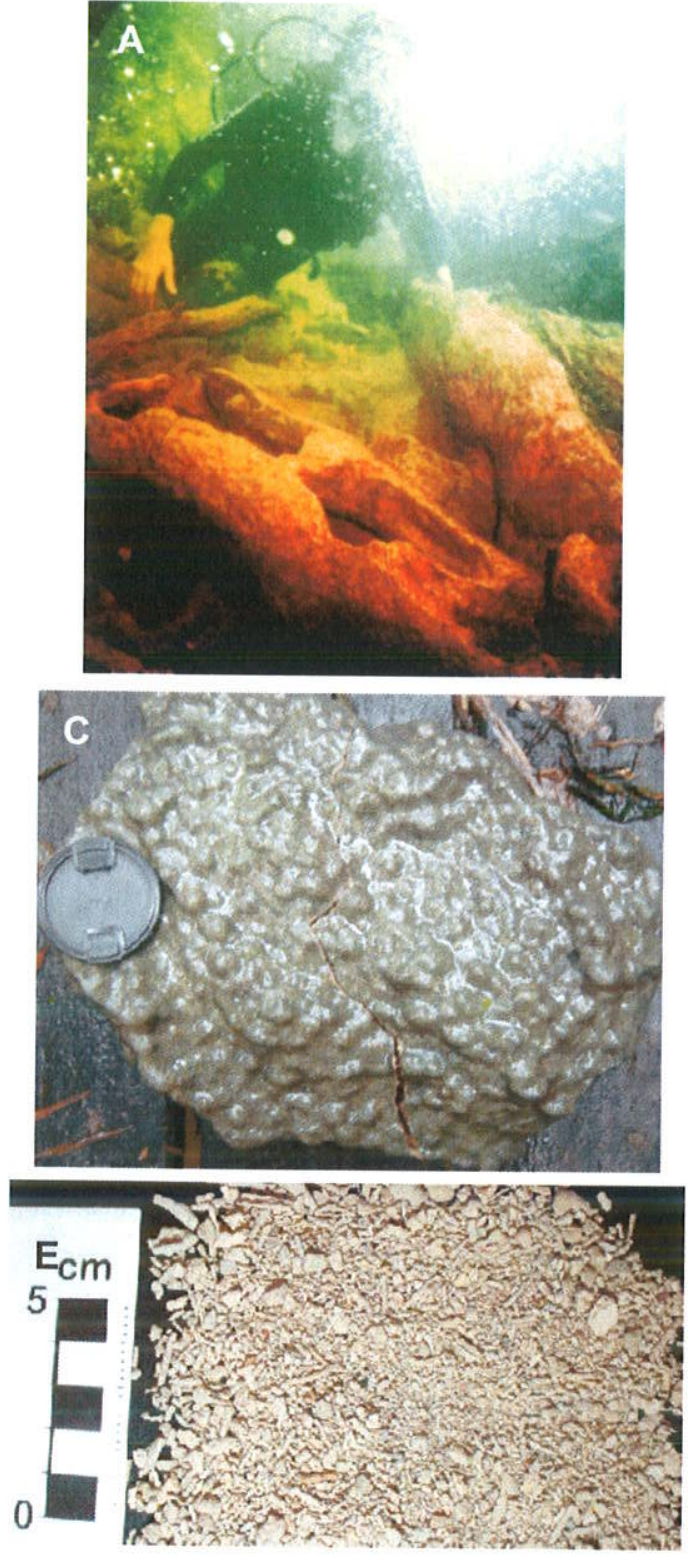

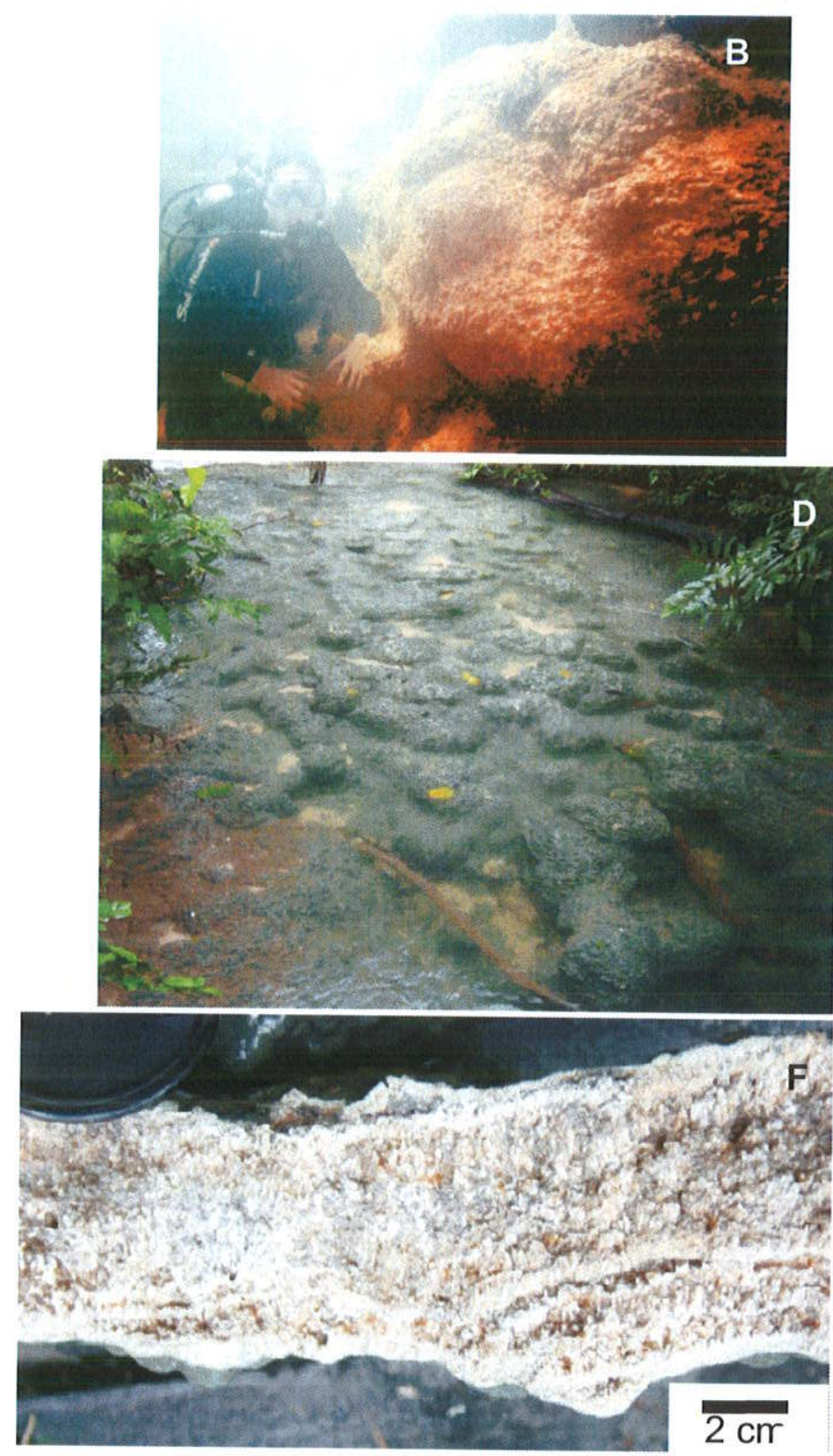

in

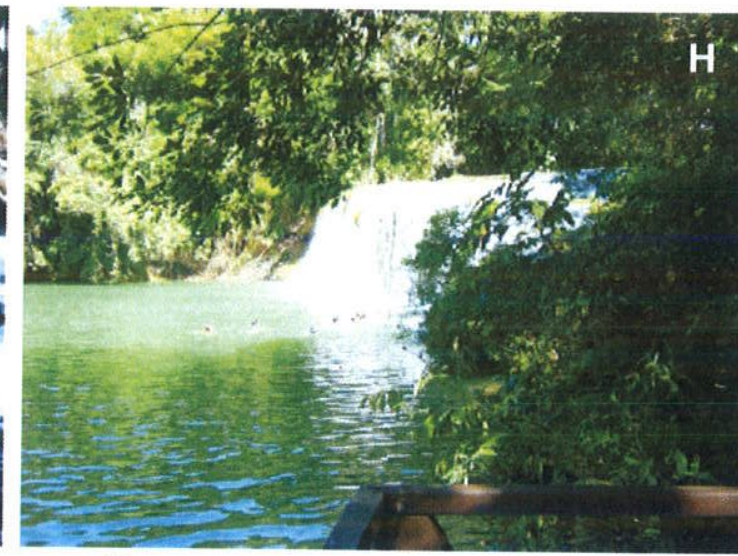

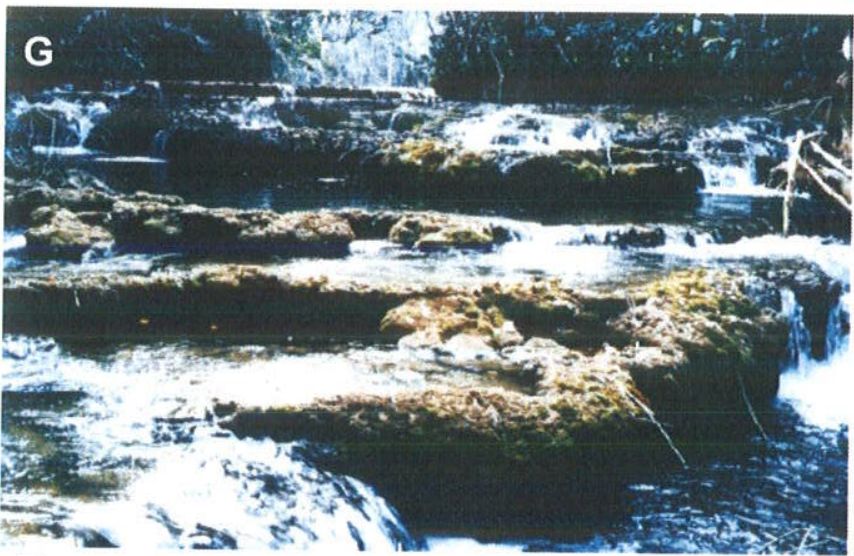

Figura 4.17: Tufas ativas. A- Tronco incrustado e sedimentos compostos por carapaças mineralizadas de algas caráceas (Ponto 84, Rio Formoso); B- Bioconstruções (Ponto 84 Rio Formoso); C- Amostra de bioconstrução (D) com aspecto "globular' e cor esverdeada dada pelas algas (Ponto 89, alto curso do Rio Formoso); D- Bioconstruções (Ponto 89, alto curso do Rio Formoso); E- Carapaças mineralizadas de algas caráceas e psólitos do Rio Formoso; F- Corte na amostra da fotografia C; G- Represas no Rio do Peixe (Ponto 86); H- Grande represa no Rio Mimoso (Ponto 85). 

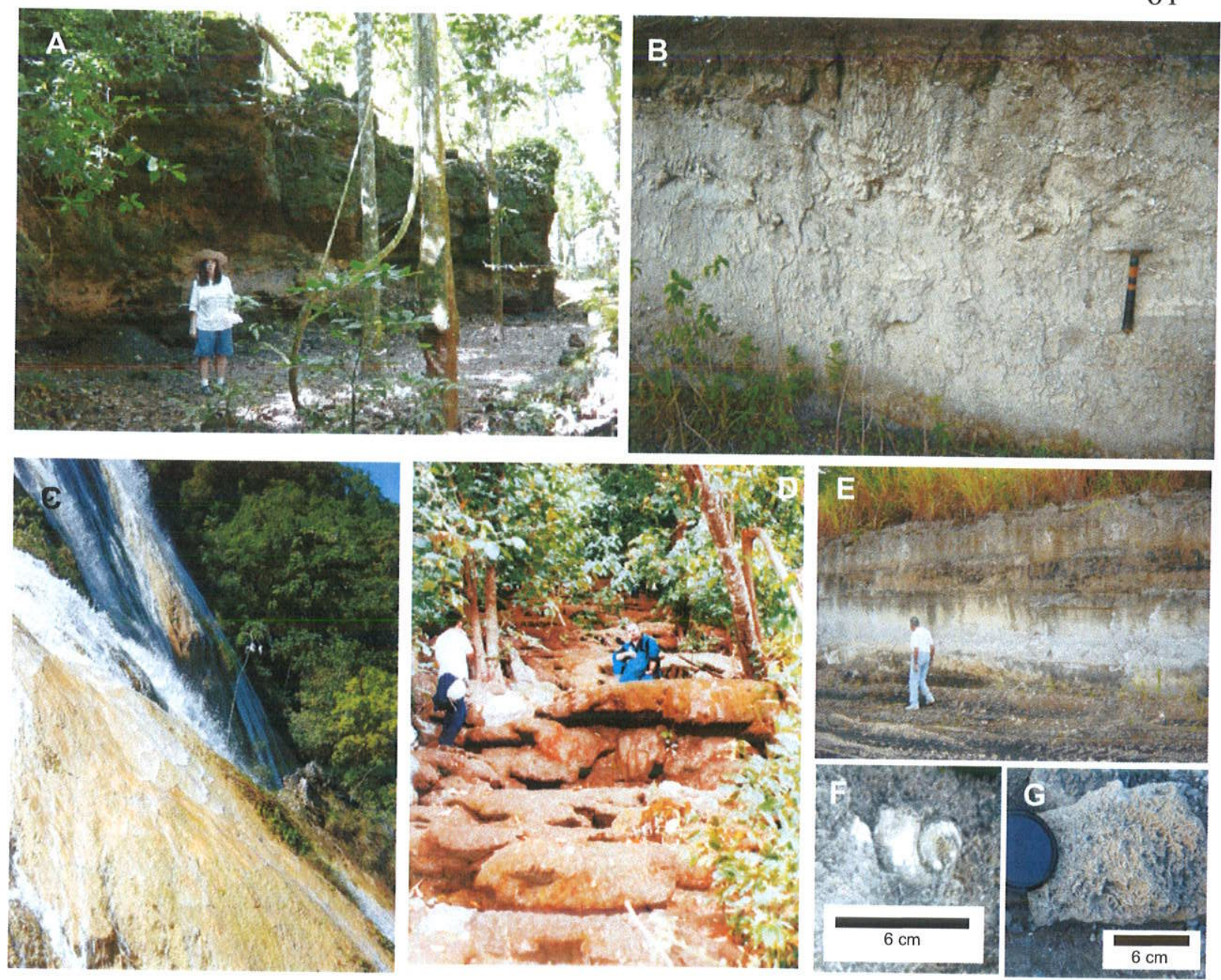

H

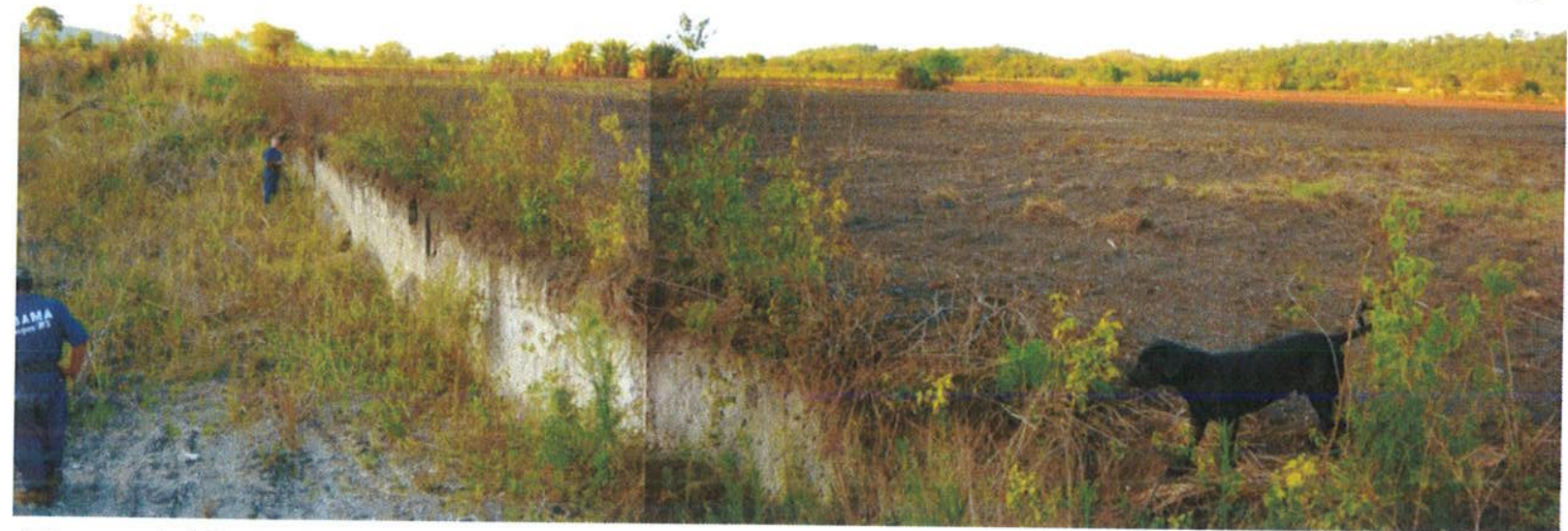

Figura 4.18: A- Depósito de tufa em terraço do Rio Mimoso (Ponto 85); B e H- Depósito de tufas antigas em Pedreira (B) no Assentamento Campina (Ponto 157), associado a planícies $(\mathrm{H})$; C- Deposição ativa de tufas no leito da cachoeira do Rio Aquidaban (Ponto 90); D- Represas de tufas (intermitentes) na ressurgência da Gruta Urubu-Rei (próx. ao ponto 42); E- "Calcário Xaraiés" (Ponto 87); F e G- Concha de gastrópode e capaças de algas em tufa na pedreira no Assentamento Campina (Ponto 157). 

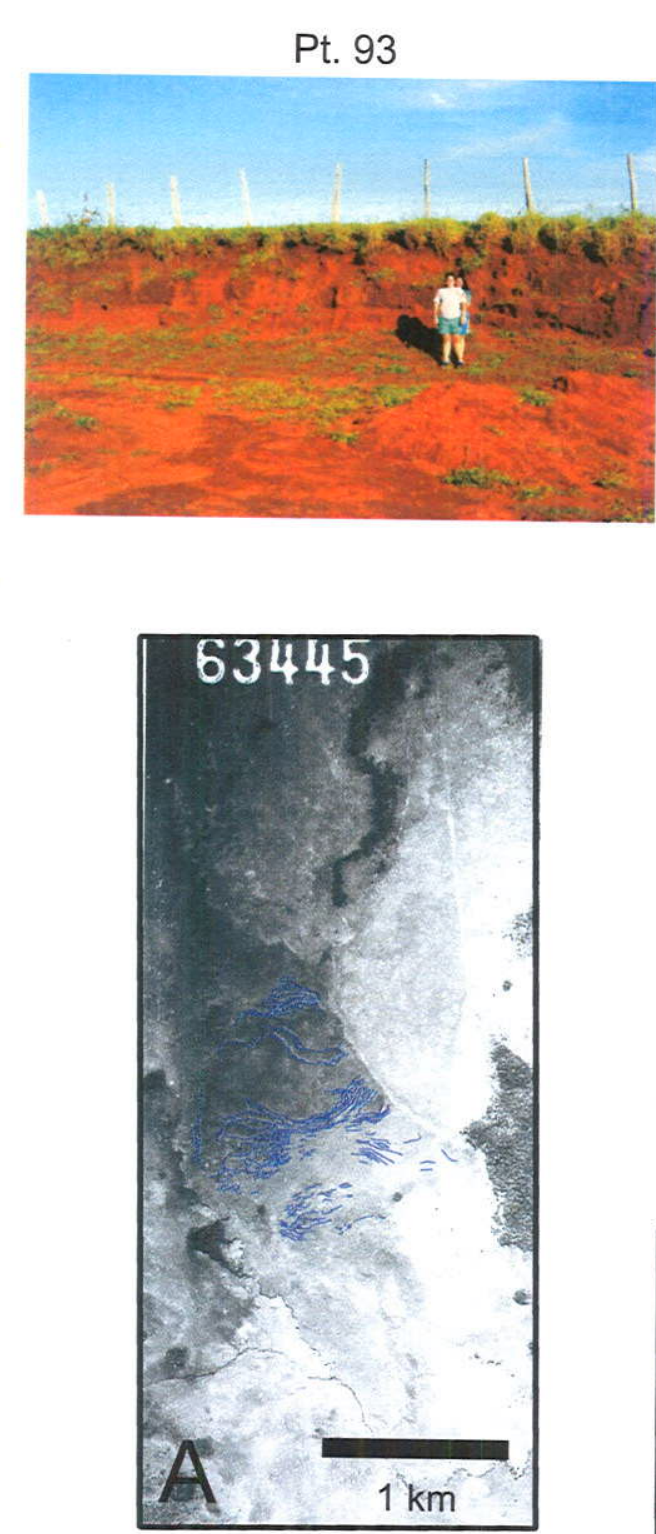
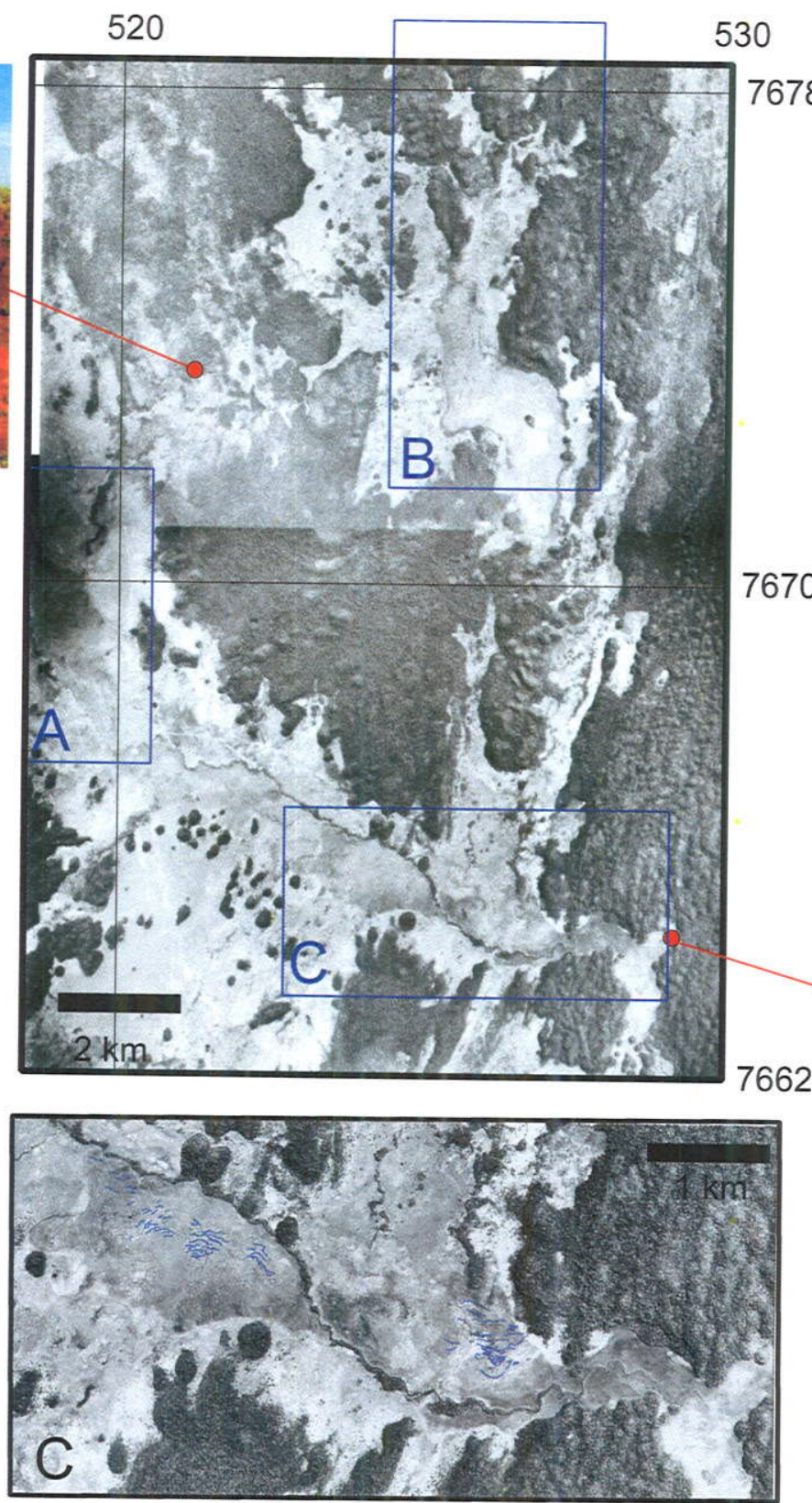

Figura 4.19: Detalhe dos depósitos de tufas na região da planície do Rio Perdido e afluentes, na unidade CLCP (calcários), no Planalto da Bodoquena. 


\subsubsection{Planícies areníticas com dolinas - PAD}

Trata-se de uma superfície aplainada disposta em rampa suave entre as cotas topográficas de 200 a $400 \mathrm{~m}$ desenvolvida sobre os arenitos da Formação Aquidauana (Planalto de Maracaju-Campo Grande). Esta superficie representa uma continuidade das planícies com dolinas da unidade PCMR no domínio dos dolomitos, recoberta pelos arenitos que gradativamente aumentam em espessura para leste (Figura 4.4 e Anexos 4 e 5).

A superfície desenvolvida nesta unidade é praticamente plana à primeira vista ou em mapas topográficos em escala 1:100.000 e 1:50.000 (Figura 4.3A), devido a grande amplitude das depressões. Isto é bem claro quando observamos o índice de rugosidade muito baixo de 1,0003 (Tabela 4.1), obtido com base topográfica em escala 1:100.000. Porém quando observamos o campo de dolinas da Fazenda Chapéu de Pano (pontos 120 a 127) (Figura 4.24 e Anexo 2) temos um índice de rugosidade de 1,001, maior do que da unidade como um todo.

Estas dolinas ocorrem tanto com uma cobertura arenítica original como também com cobertura de solo areno-argiloso, derivado tanto dos arenitos quanto dos calcários, por vezes com fragmentos de quartzo de veio (provenientes do calcário) ou também em seixos (proveniente da Formação Aquidauana). O calcário aflora em algumas dolinas como blocos ou karren no epicarste (Figura 4.22).

Em campo foram localizadas diversas dolinas com diâmetros e profundidades muito variadas, atingindo o diâmetro máximo de $700 \mathrm{~m}$ e profundidade de até $75 \mathrm{~m}$ (Tabela 4.2). Geralmente são dolinas menores contidas em grandes depressões maiores, de difícil delimitação, pois são muito amplas e suaves. O mapeamento de dolinas em campo visou sua localização e caracterização quanto à forma em planta e em perfil, e também quanto às suas características geológicas. Observou-se uma quantidade de dolinas muito maior do que se esperava, assim optando-se pela definição de algumas áreas de amostragem, pois o mapeamento de todas as dolinas em campo é praticamente impossivel. $\mathrm{Na}$ Tabela 4.2 estão resumidas as caracteristicas das dolinas mapeadas.

Duas áreas foram detalhadas: uma na Fazenda Santa Maria (conhecido também como "Passo do Curê") e outra na Fazenda Chapéu de Pano (Figuras 4.20, 4.21, 4.22, 4.23 e 4.24). Nestas duas áreas foram identificados dois tipos morfológicos de dolinas.

Sua morfologia varia entre depressões com vertentes suaves a abruptas, apresentando uma relação entre profundidade e o diâmetro (P/D) que varia 0,05 a 1 . 
A morfologia dominante corresponde a dolinas com uma relação P/D baixa, vertentes de inclinação suave, fundo plano ou presença de lago. O melhor exemplo deste tipo é a dolina da "Lagoa Vermelha", na Fazenda Chapéu de Pano (Ponto 120), que possui forma ampla e rasa, com cerca de $700 \mathrm{~m}$ de diâmetro por $50 \mathrm{~m}$ de profundidade $(P / D=0.05)$, nos arenitos (Figura 4.24). No Ponto 68 ocorre outra grande dolina ampla e suave (Figura 4.23B), com lago, ao lado da estrada Jardim-Porto Murtinho.

A morfologia menos freqüente corresponde a dolinas com relação P/D maior do que do tipo anterior, vertentes de alta inclinação, com presença de lago ou fundo plano. Como exemplos deste tipo temos o Buraco das Araras, próximo à Fazenda Santa Maria, que é a dolina mais conhecida da região (Figura 4.23A). É uma dolina elíptica com paredes escarpadas (verticais), orientada a N50W, com $125 \mathrm{~m}$ por $70 \mathrm{~m}$ de eixos maior e menor, e $60 \mathrm{~m}$ de profundidade $(P / D=0.48)$. Desenvolvem-se nos arenitos da Formação Aquidauana. Um lago ocorre no fundo da depressão. As estruturas observadas por Lino et al. (1984) são fraturas N30-50W/60-70NE e N30-40E/sub-vertical que coincidem com o eixo maior e menor da dolina, além de um acamamento subhorizontal $\left(5-10^{\circ}\right)$. Na Fazenda Santa Maria a Lagoa Misteriosa é maior dolina deste tipo com $400 \mathrm{~m}$ de diâmetro, $75 \mathrm{~m}$ de profundidade $(P / D=0.18)$ e vertentes inclinadas, que dá acesso a uma caverna, subaquática com desenvolvimento preferencial vertical, que alcança uma profundidade de $220 \mathrm{~m}$ (Figura 4.22). Desenvolve-se no dolomitos (mármores), sendo que na superficie ocorre um capeamento de arenitos da Formação Aquidauana, com espessura métrica. Algumas dolinas desenvolvidas em solo residual da Formação Aquidauana possuem vertentes verticais, como a dolina do Ponto $103 \mathrm{com}$ P/D de 1, o mais alto observado.

Com o objetivo de identificar a orientação preferencial de agrupamentos de feições cársticas, foram traçados alinhamentos de dolinas, nascente e cavernas, localizadas em campo. Na Fazenda Santa Maria ocorre a transição entre a cobertura arenítica e o calcário subjacente, de tal forma que de leste para oeste a espessura da cobertura vai diminuindo e vão surgindo morros de calcário, com cavernas (Figura 4.20). As feições cársticas encontram-se alinhadas em três direções principais: NS, N45W e N70E (Figuras 4.21 e 4.22). Os alinhamentos com orientação N70E foram relacionados ao sistema de fraturas com atitude N70E/sub-vertical (Figuras 4.21 e 4.22). As cavernas próximas possuem direções principais de condutos segundo N50W e N65E (Figura 4.21). Na Fazenda Chapéu de Pano as dolinas são muito amplas e suaves e todas em solo arenoso e arenito (Figura 4.20). Os alinhamentos observados aqui são N15W e 
N60E, porém não foram medidas estruturas (Figura 4.24). As dolinas dos pontos $124 \mathrm{e}$ 125 e dos pontos 121, 122 e 123 são conjuntos de dolinas menores dentro de depressões maiores, como pode ser visto na Figura 4.24. Os alinhamentos de feições indicam as direções dos condutos, que se desenvolvem em profundidade, como observado por alguns autores como Parizek (1976).

O recuo da escarpa arenítica expõe o calcário subjacente. As cavernas muitas vezes são acessadas por dolinas. Descrições de moradores locais indicam que algumas dolinas crescem rapidamente. Em uma destas dolinas foi construído um açude que secou em alguns dias.

Estas feições de colapso e erosão subterrânea nos arenitos evidenciam o desenvolvimento de um sistema cárstico profundo, em ambiente freático, nas rochas carbonáticas abaixo dos arenitos Aquidauana, caracterizando desta maneira, um carste interestratal associado principalmente à Formação Cerradinho, e também aos mármores do Grupo Cuiabá. A alta frequêencia de dolinas neste setor permitiria classificá-lo como um carste dominado por dolinas (doline karst, White, 1988), porém como se trata de um carste interestratal preferiu-se não adotar este termo. 
Tabela 4.2: Características gerais das dolinas mapeadas.

\begin{tabular}{|c|c|c|c|c|c|c|c|c|c|c|c|c|}
\hline Pto. & Local & UTM & $\begin{array}{c}\text { Forma } \\
\text { em } \\
\text { planta }\end{array}$ & $\begin{array}{l}\text { Direção } \\
\text { do eixo } \\
\text { major }\end{array}$ & $\begin{array}{c}\text { Forma em } \\
\text { perfil }\end{array}$ & $\begin{array}{l}\text { Sentido da } \\
\text { Assimetria }\end{array}$ & $\begin{array}{c}\text { Dimensōes } \\
\text { em planta } \\
\text { (m) }\end{array}$ & $\begin{array}{l}\text { Prof. } \\
\text { (m) }\end{array}$ & Rocha & Estruturas* & Lago & $\underset{* *}{P / D}$ \\
\hline 26 & $\begin{array}{l}\text { Lagoa Misteriosa - } \\
\text { Faz. Sta. Maria }\end{array}$ & $\begin{array}{c}556748 \\
7627057\end{array}$ & Elíptica & N35E & Simétrica & -..- & $\sim 400 \times 200$ & 75 & $\begin{array}{l}\text { Calcário e } \\
\text { peq. } \\
\text { cobertura de } \\
\text { arenito }\end{array}$ & $\begin{array}{c}\text { Fraturas: } \\
\text { N270/80S } \\
\text { N260/subvert. } \\
\text { N240/subvert. } \\
\text { N215/subvert. } \\
\text { N280/subvert. } \\
\text { N250 } \\
\text { N25/30SE } \\
\text { N70/subvert. } \\
\text { N300/subvert. } \\
\text { N90/subvert. } \\
\text { So-N05/25SE }\end{array}$ & $\operatorname{Sim}$ & 0,18 \\
\hline 27 & Faz. Sta. Maria & $\begin{array}{c}556292 \\
7626638\end{array}$ & Elíptica & NS & $\begin{array}{c}\text { Assimétrica, } \\
\text { parte } \\
\text { escarpada }\end{array}$ & Norte & $\begin{array}{l}30 \text { (eixo } \\
\text { maior) }\end{array}$ & 6 & Solo & $-\infty$ & - & 0,2 \\
\hline 28 & Faz. Sta. Maria & $\begin{array}{r}556192 \\
7627017 \\
\end{array}$ & Eliptica & N7OE & $\begin{array}{l}\text { Simétrica, } \\
\text { escarpada }\end{array}$ & - & $\begin{array}{c}150 \text { (eixo } \\
\text { maior) }\end{array}$ & 20 & $\begin{array}{l}\text { Solo e } \\
\text { Calcário }\end{array}$ & - & $-\cdots$ & 0,13 \\
\hline 29 & Faz. Sta. Maria & $\begin{array}{c}555764 \\
7626950 \\
\end{array}$ & Circular & - & Simétrica & - - & $20 \mathrm{~m}$ & 2 & Solo & - & - - & 0,1 \\
\hline 30 & Faz. Sta. Maria & $\begin{array}{c}556164 \\
7626732 \\
\end{array}$ & Elíptica & N10E & $\begin{array}{l}\text { Simétrica, } \\
\text { escarpada }\end{array}$ & - & $\begin{array}{l}50 \text { (eixo } \\
\text { maior) }\end{array}$ & 15 & Solo & - & +-- & 0,3 \\
\hline 68 & $\begin{array}{l}\text { Estrada Jardim- } \\
\text { Porto Murtinho }\end{array}$ & $\begin{array}{r}553075 \\
7621516 \\
\end{array}$ & Circular & $\cdots$ & Simétrica & (-.-. & 500 & 50 & Solo (?) & $\cdots$ & $\operatorname{Sim}$ & 0,1 \\
\hline 101 & Faz. Sta. Maria & $\begin{array}{c}556495 \\
7626268 \\
\end{array}$ & $\begin{array}{c}\text { Circular } \\
\text { (?) }\end{array}$ & --בי- & Simétrica & $-\cdots$ & $\sim 100$ & $\sim 5$ & Solo & - & -..- & 0,05 \\
\hline 102 & Faz. Sta. Maria & $\begin{array}{l}556273 \\
7626061\end{array}$ & $\begin{array}{l}\text { Circular } \\
\text { (?) }\end{array}$ & 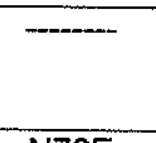 & Simétrica & - & $\sim 100$ & $\sim 5$ & $\begin{array}{c}\text { Solo e } \\
\text { Calcário } \\
\text { (karren) }\end{array}$ & $\begin{array}{c}\text { Fraturas: } \\
166 / 85 \\
256 / 80 \\
\end{array}$ & $---m$ & 0,05 \\
\hline 103 & Faz. Sta. Maria & $\begin{array}{c}556104 \\
7626042\end{array}$ & Elíptica & N76E & $\begin{array}{l}\text { Simétrica, } \\
\text { escarpada }\end{array}$ & - & 30 & 30 & $\begin{array}{c}\text { Solo, } \\
\text { Cascalheira, } \\
\text { Calcário } \\
\text { (epicarste) e } \\
\text { Metarenito }\end{array}$ & $\begin{array}{c}\text { Fraturas: } \\
65 / 90 \\
170 / 80 \\
\text { So-140/55 } \\
\text { (metarenito) }\end{array}$ & - & 1 \\
\hline 104 & Faz. Sta. Maria & $\begin{array}{c}556779 \\
7625910 \\
\end{array}$ & $\begin{array}{l}\text { Elíptica } \\
\text { (irregular) }\end{array}$ & N40W & Simétrica & $\cdots$ & 50 & 2 & Solo & - & $\cdots$ & 0,04 \\
\hline
\end{tabular}




\begin{tabular}{|c|c|c|c|c|c|c|c|c|c|c|c|c|}
\hline 105 & Faz. Sta. Maria & $\begin{array}{r}556762 \\
7626048 \\
\end{array}$ & $\begin{array}{l}\text { Eliptica } \\
\text { (irregular) }\end{array}$ & N05W & $\begin{array}{l}\text { Simétrica, } \\
\text { escarpada }\end{array}$ & - & 15 & 6 & Solo & $\cdots$ & $-\cdots$ & 0,4 \\
\hline 106 & Faz. Sta. Maria & $\begin{array}{c}556813 \\
7626056 \\
\end{array}$ & $\begin{array}{l}\text { Circular } \\
(?)\end{array}$ & - & Simétrica & - & 8 & 0,5 & Solo & --- & - & 0,06 \\
\hline 107 & Faz. Sta. Maria & $\begin{array}{r}557429 \\
7626563 \\
\end{array}$ & Eliptica & $\mathrm{N} 40 \mathrm{E}$ & Simétrica & - & 300 & -20 & $\begin{array}{l}\text { Solo e blocos } \\
\text { de calcário }\end{array}$ & (2) & $-m$ & 0,06 \\
\hline 108 & Faz. Sta. Maria & $\begin{array}{c}557428 \\
7627334 \\
\end{array}$ & Circular & -- & Simétrica & 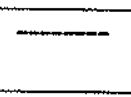 & 300 & $\sim 20$ & Solo & $-\cdots$ & - & 0,06 \\
\hline 109 & $\begin{array}{l}\text { Faz. Sta. Maria (?) } \\
\text { - estrada terra } \\
\text { Bonito-Jardim }\end{array}$ & $\begin{array}{l}556405 \\
7623671\end{array}$ & Circular & (--- & Simétrica & - & $?(\sim 300)$ & $\begin{array}{c}? \\
(\sim 20)\end{array}$ & Solo & $-\cdots$ & --.--- & 0,06 \\
\hline 119 & $\begin{array}{l}\text { Estrada terra } \\
\text { Bonito-Jardim }\end{array}$ & $\begin{array}{c}557237 \\
7636578\end{array}$ & Elíptica & $\mathrm{N} 12 \mathrm{E}$ & $\begin{array}{l}\text { Simétrica, } \\
\text { escarpada }\end{array}$ & $\cdots$ & 70 & 10 & $\begin{array}{l}\text { Solo, blocos } \\
\text { de calcário e } \\
\text { filito }\end{array}$ & --- & --- & 0,14 \\
\hline 120 & $\begin{array}{l}\text { Faz. Chapéu de } \\
\text { Pano }\end{array}$ & $\begin{array}{r}549043 \\
7610013 \\
\end{array}$ & Circular & - & Simétrica & 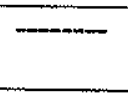 & 700 & $\sim 50$ & Arenito & ----- & $\operatorname{Sim}$ & 0,07 \\
\hline 121 & $\begin{array}{l}\text { Faz. Chapéu de } \\
\text { Pano }\end{array}$ & $\begin{array}{c}548470 \\
7611907 \\
\end{array}$ & Circular & $\cdots$ & Simétrica & - & $\sim 300$ & $-\cdots$ & Solo (areia) & $\cdots$ & $-\cdots$ & - \\
\hline 122 & $\begin{array}{l}\text { Faz. Chapéu de } \\
\text { Pano }\end{array}$ & $\begin{array}{c}548487 \\
7612210 \\
\end{array}$ & Circular & --- & Simétrica & - & -300 & $-\cdots$ & Solo (areia) & - & - & $\cdots$ \\
\hline 123 & $\begin{array}{l}\text { Faz. Chapéu de } \\
\text { Pano }\end{array}$ & $\begin{array}{c}548139 \\
7612050 \\
\end{array}$ & Circular & - & Simétrica & $-\cdots$ & -300 & $-\cdots$ & Solo (areia) & - & $-m$ & +--- \\
\hline 124 & $\begin{array}{l}\text { Faz. Chapéu de } \\
\text { Pano }\end{array}$ & $\begin{array}{r}549438 \\
7613947 \\
\end{array}$ & Cirular & - & Simétrica & - & 100 & 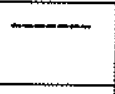 & Solo (areia) & - & 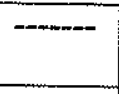 & $-\cdots$ \\
\hline 125 & $\begin{array}{l}\text { Faz. Chapéu de } \\
\text { Pano }\end{array}$ & $\begin{array}{c}549368 \\
7614373 \\
\end{array}$ & Elíptica & N2OW & Simétrica & 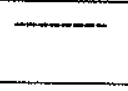 & - & $-\cdots$ & Solo (areia) & - & $--\cdots$ & $+\cdots$ \\
\hline 126 & $\begin{array}{l}\text { Faz. Chapéu de } \\
\text { Pano }\end{array}$ & $\begin{array}{r}548937 \\
7615944 \\
\end{array}$ & $\begin{array}{c}\text { Circular } \\
\text { (?) }\end{array}$ & $-\cdots$ & Simétrica & - & $-\infty$ & $\cdots$ & Solo (areia) & --- & $m$ & m--- \\
\hline 128 & $\begin{array}{l}\text { Faz. Chapéu de } \\
\text { Pano }\end{array}$ & $\begin{array}{c}548825 \\
7616146 \\
\end{array}$ & Eliptica & N10WE & Assimétrica & N190 & - & $-\infty$ & Solo (areia) & $-\cdots$ & $+\cdots$ & +- \\
\hline \multirow{2}{*}{128} & $\begin{array}{l}\text { Faz. Sta. Maria (?) } \\
\text { - estrada terra } \\
\text { Bonito-Jardim }\end{array}$ & $\begin{array}{c}556200 \\
7623305\end{array}$ & $\begin{array}{c}\text { Circular } \\
\text { (?) }\end{array}$ & - & $\longrightarrow$ & - & 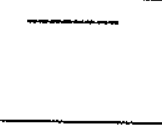 & - & Solo & - & --- & --- \\
\hline & Buraco das Araras & $\begin{array}{r}561834 \\
7623338 \\
\end{array}$ & Elíptica & N50W & Simétrica & $-\cdots$ & $\begin{array}{r}125 \\
\times 70 \\
\end{array}$ & 60 & Arenito & $\cdots$ & $\operatorname{Sim}$ & 0,48 \\
\hline
\end{tabular}




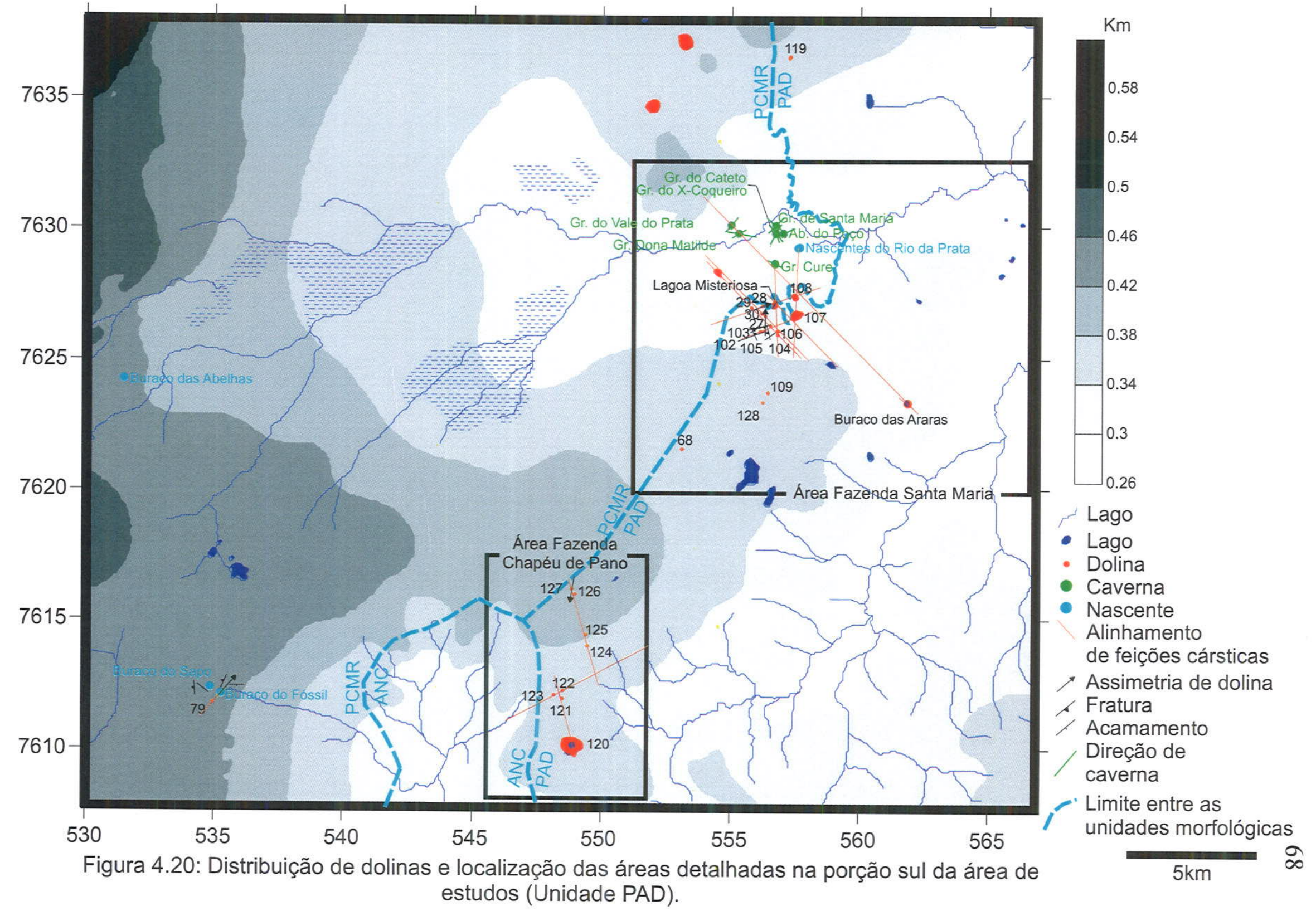




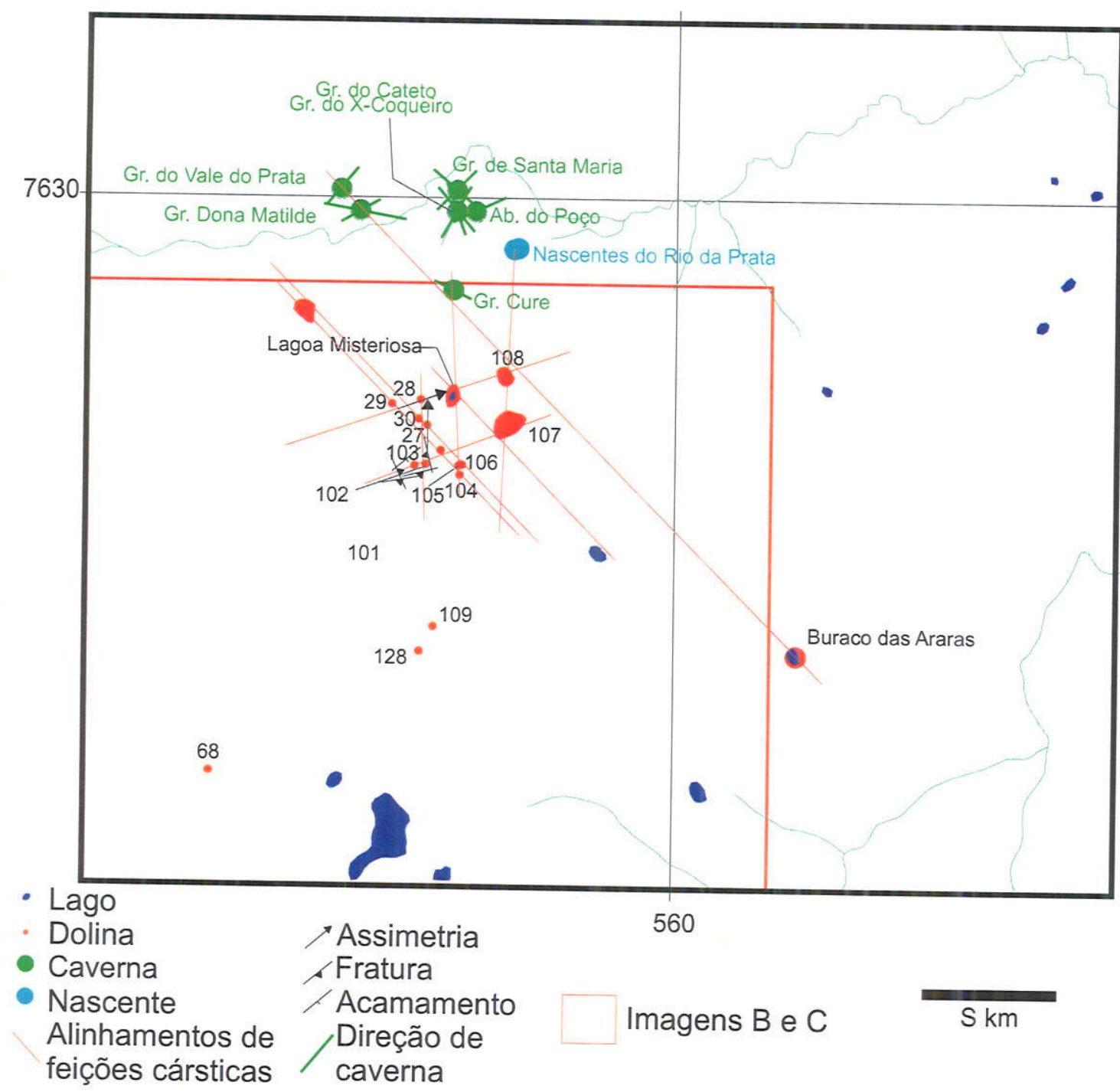

Figura 4.21: A- Campo de dolinas mapeada na Área da Fazenda Santa Maria (Unidade PAD) com detalhes em imagem LANDSAT 7; B- Banda 4 em pseudocor azul ("waterlevel"); C- Composição R7G5B3 + PC1 (intensidade).
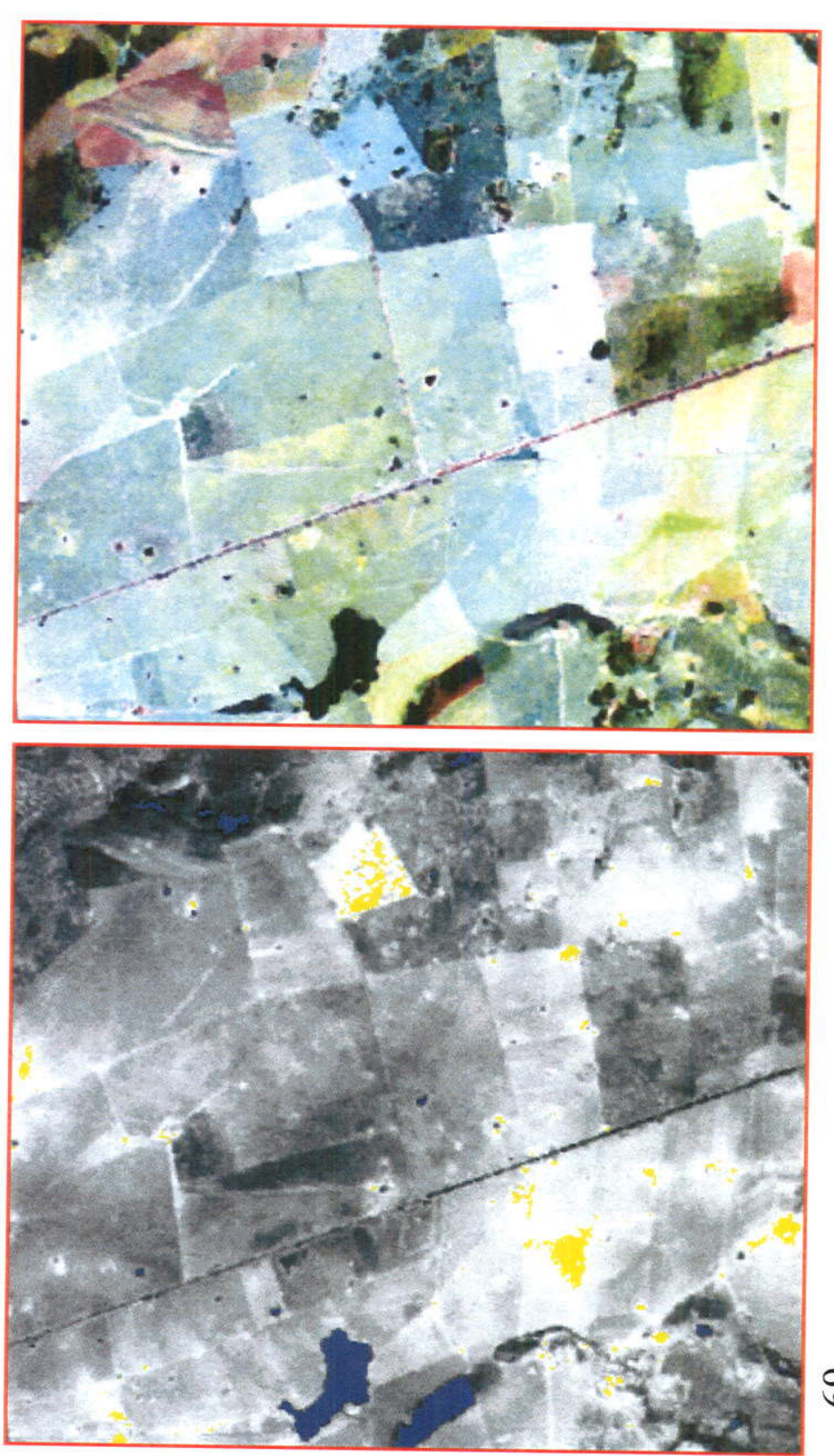


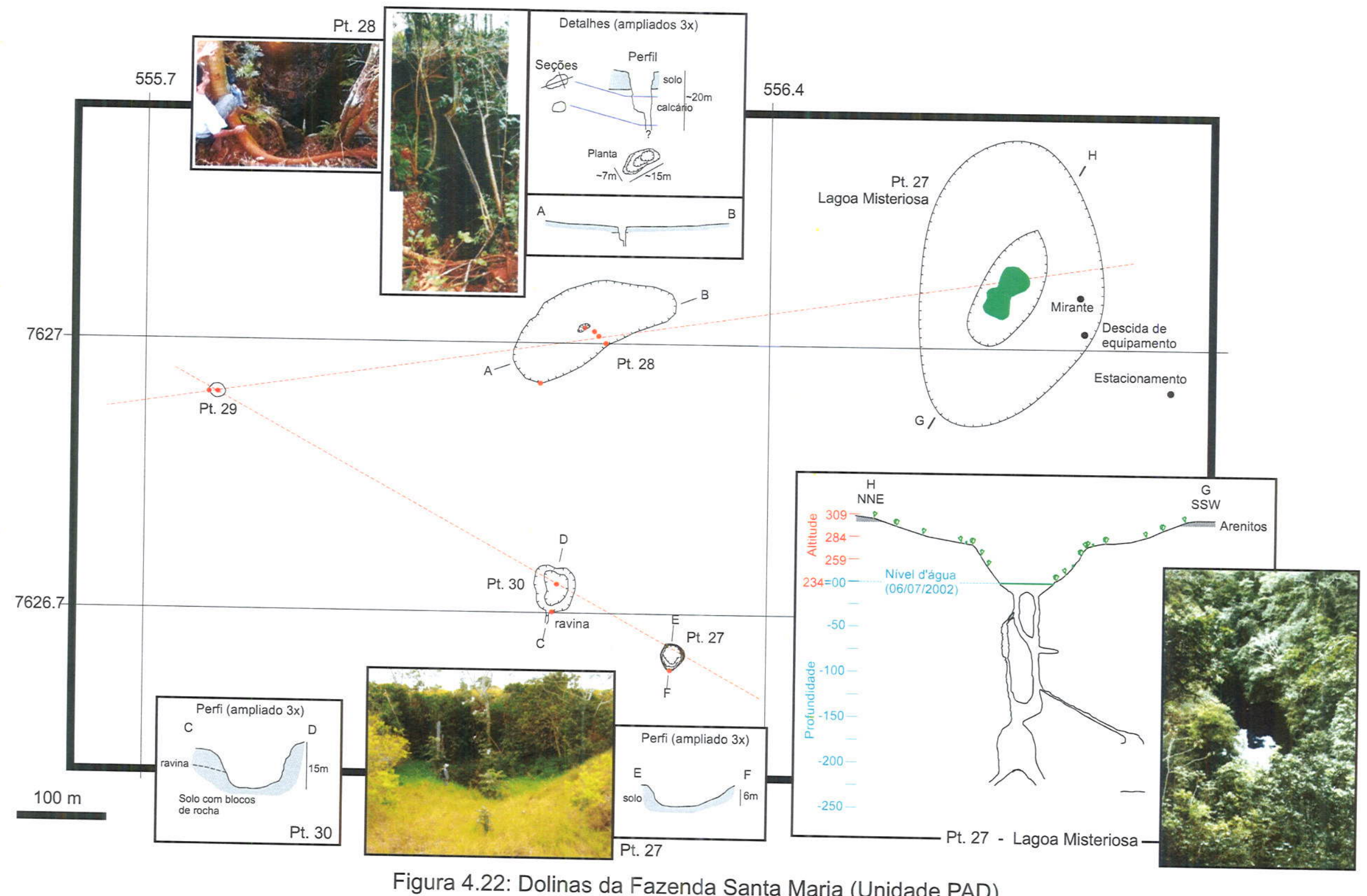




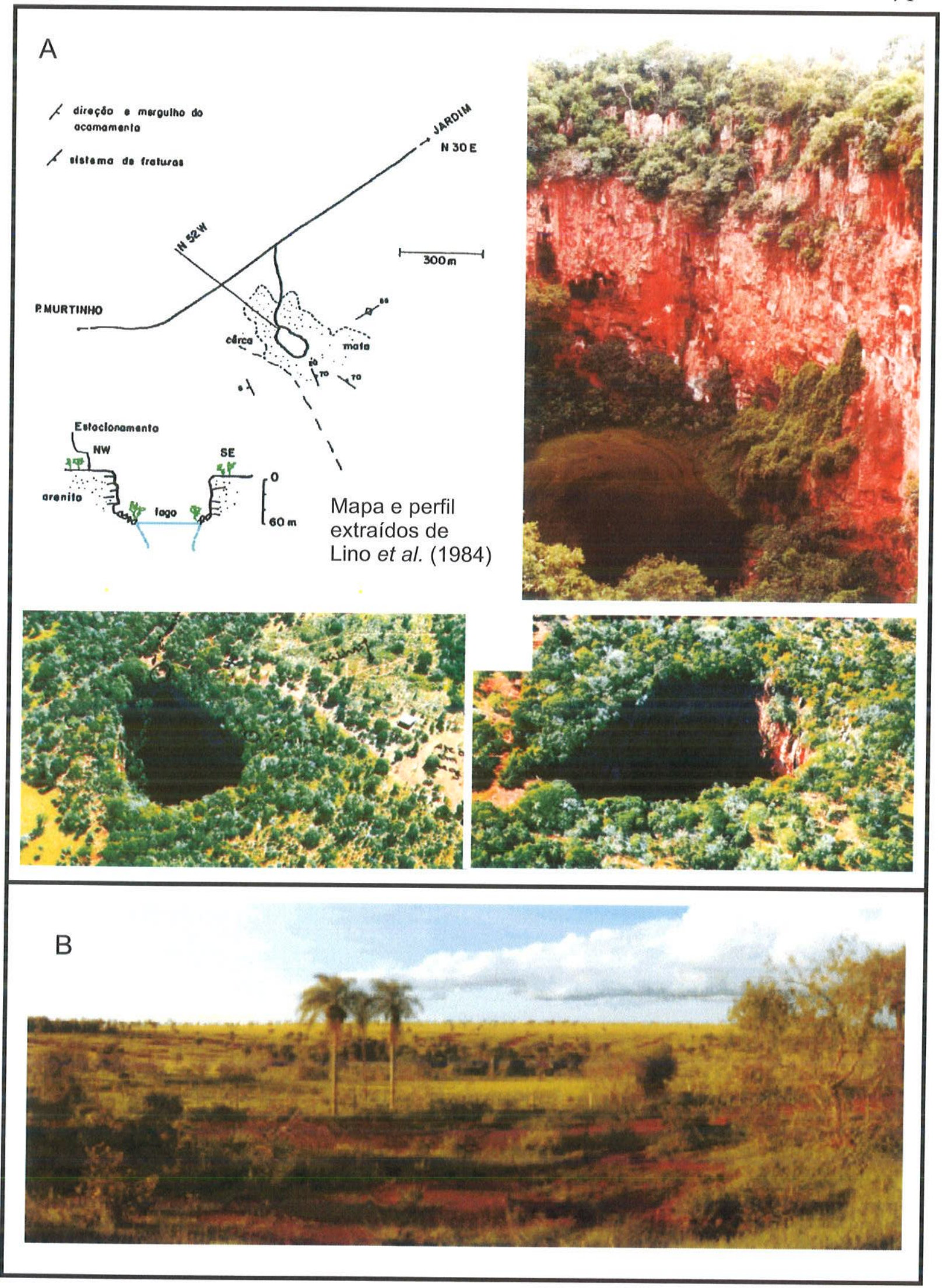

Figura 4.23: A- Buraco das Araras; B- Dolina do ponto 68. 


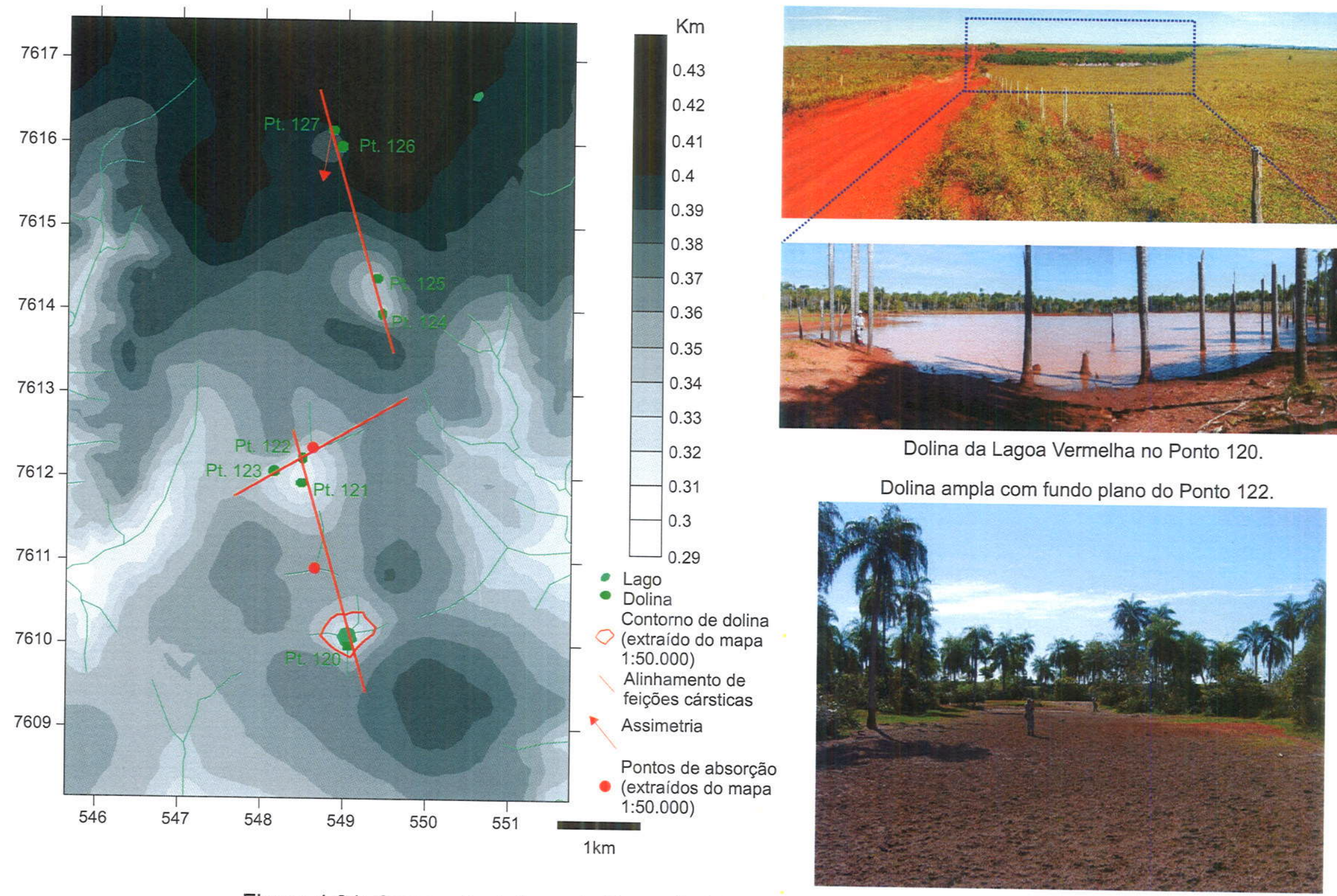

Figura 4.24: Campo de dolinas da Fazenda Chapéu de Pano (Unidade PAD). 


\subsection{Tipos de rochas carbonáticas e relevo}

A identificação de formas de relevo sobre as rochas carbonáticas $e$ a compartimentação morfológica da área revelou setores com padrões de relevo muito contrastante, conforme anteriormente descrito no Capítulo 1 e detalhado mais adiante no Capítulo 6. A compartimentação geral mostrou uma área carbonática topograficamente alta e, outra, relativamente rebaixada. Isto é evidente na porção sul da Serra da Bodoquena onde a Unidade CLCP, situada no Planalto da Bodoquena, encontra-se elevada em relação à Unidade PCMR, na Depressão do Rio Miranda, sendo limitada por uma escarpa. Com o objetivo de testar a influência da natureza da rocha carbonática sobre esta compartimentação e obter parâmetros de solubilidade destas rochas para fundamentar a discussão sobre a ocorrência de movimentos tectônicos recentes nesta compartimentação (Capítulo 6), as rochas carbonáticas foram classificadas com base na relação $\mathrm{CaO}$ e $\mathrm{MgO}$ e porcentagens relativas de calcita, dolomita e impurezas (terrígenos). Foram utilizadas análises químicas de 147 amostras, distribuídas sobre toda área carbonática, 64 obtidas no presente trabalho e 83 disponiveis em Nogueira \& Oliveira (1978).

Para toda a serra dois grupos distintos de rochas carbonáticas foram confirmados, um de calcários e outro de dolomitos, ambos dominantemente puros, com termos intermediários pouco freqüentes (Figuras $25 \mathrm{~A} \mathrm{e} \mathrm{B}$ ).

A

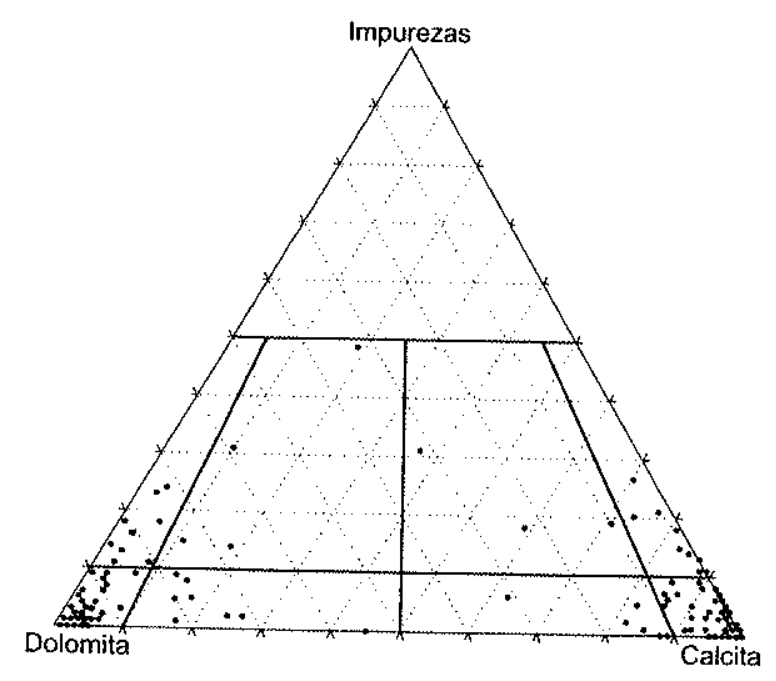

B

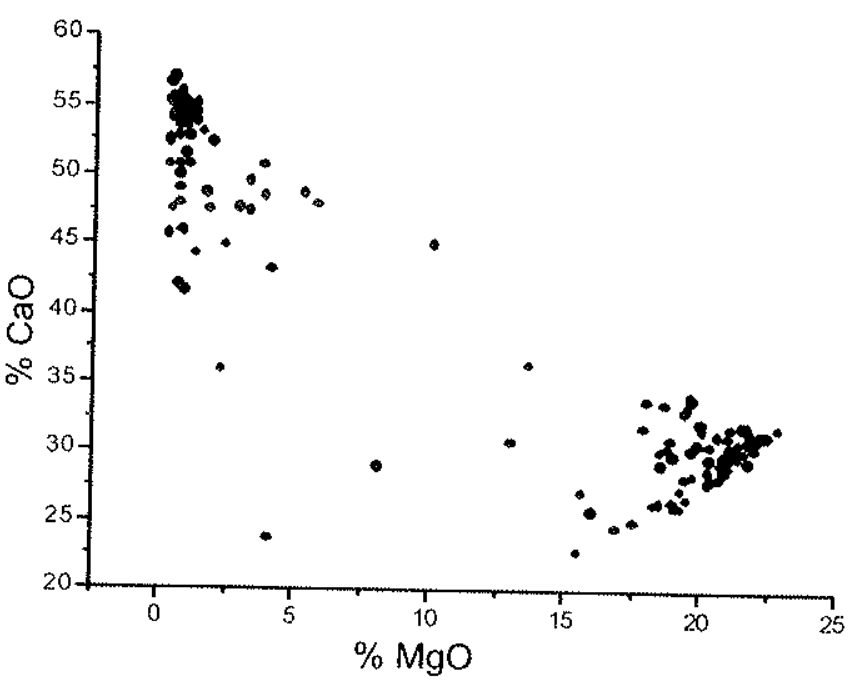

Figura 4.25: A- Representação em diagrama triangular (classificação de Leighton \& Pendexter, 1962) dos resultados analíticos de 147 amostras de rochas carbonáticas. BRelação entre $\mathrm{CaO}$ e $\mathrm{MgO}$ das 147 amostras. 
$\mathrm{Na}$ Tabela 4.3 apresentam-se as características químicas destes dois grupos relacionados às duas unidades de relevo principais. Nota-se que as rochas da Unidade CLCP no Planalto da Bodoquena possuem, em média, teores muito baixos de dolomita e de impurezas, tratando-se assim de calcários puros. Há variação nos teores de calcita e de impurezas, como evidenciado pelo coeficiente de variação. Já as rochas da Unidade PCMR na Depressão do Rio Miranda possuem, em média, teores ainda elevados de calcita com baixos teores de impurezas. Na Unidade PCMR há uma intercalação de dolomitos com calcários, que em média são representados por dolomitos, porém com variação evidenciada pelo maior coeficiente de variação da calcita nestas rochas, além de uma alta variação nos teores de impurezas.

Tabela 4.3: Composições quimicas das rochas carbonáticas nas unidades CLCP e PCMR.

\begin{tabular}{|c|c|c|c|c|c|c|c|c|c|}
\hline \multicolumn{10}{|c|}{ Unidades morfológicas } \\
\hline \multicolumn{5}{|c|}{$\begin{array}{c}\text { CLCP } \\
\text { (no Planalto da Bodoquena) }\end{array}$} & \multicolumn{5}{|c|}{$\begin{array}{c}\text { PCMR } \\
\text { (na Depressão do Rio Miranda) } \\
\end{array}$} \\
\hline 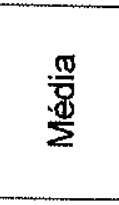 & $\frac{5}{\Sigma}$ & 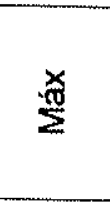 & 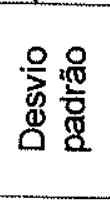 & 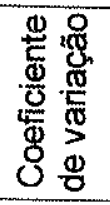 & 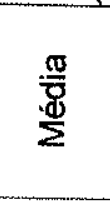 & $\stackrel{\check{\Sigma}}{\Sigma}$ & 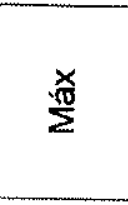 & 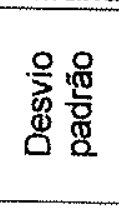 & 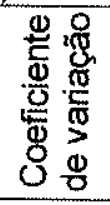 \\
\hline 7.63 & 1.43 & 96.17 & 21.48 & 2.81 & 64.45 & 1.22 & 100.00 & 42.71 & 0.66 \\
\hline 91.81 & 3.83 & 98.53 & 21.37 & 0.23 & 32.95 & 0.00 & 98.78 & 42.93 & 1.30 \\
\hline 0.67 & 0.00 & 2.67 & 0.93 & 1.38 & 2.63 & 0.00 & 20.33 & 4.48 & 1.70 \\
\hline \multicolumn{5}{|c|}{19} & \multicolumn{5}{|c|}{37} \\
\hline
\end{tabular}

O resultado da identificação litológica demonstrou que os dolomitos encontram-se rebaixados topograficamente em relação aos calcários. Esta situação topográfica é contrária ao esperado, pois calcários por serem mais solúveis que os dolomitos, deveriam estar rebaixados, considerando condições intempéricas de clima tropical úmido, como será discutido no Capítulo 6. 


\section{CAVERNAS}

Com o objetivo de caracterizar a drenagem subterrânea e o aqüifero de condutos, no contexto do sistema cárstico de Serra da Bodoquena, realizou-se o estudo da distribuição, morfologia e geologia das cavernas da área de estudo.

\subsection{Trabalhos anteriores}

A primeira citação no meio científico sobre cavernas no municipio de Bonito é de Mendes (1957), que em visita a Serra da Bodoquena registra a ocorrência de pelo menos três grutas, além de outras feições cársticas na região. Apresenta esboços $\mathrm{e}$ uma descrição geológica das Grutas do Lago Azul (Gruta da Fazenda Anhumas), com uma seção esquemática mostrando um lago raso no interior da gruta, e da Gruta Nossa Senhora Aparecida (Gruta da Fazenda Três Irmãos). Mendes (1957) ainda descreve um pouco da geologia regional, e chama a atenção, que a região seria uma fonte rica para investigações espeleológicas.

Almeida (1965) descreve algumas feições cársticas na região e coloca que "pequenas cavernas diz-se que são numerosas", mas visitou apenas a Gruta Lago Azul onde descreve que a gruta teria se desenvolvido ao longo de juntas ortogonais ao acamamento, ao contrário do descrito por Mendes (1957).

Karmann \& Sánchez $(1979,1986)$ definem a "Província Espeleológica da Serra da Bodoquena", localizada no estado do Mato Grosso do Sul e distribuída por $200 \mathrm{~km}$ na direção N-S. Segundo estes autores, na região da Serra da Bodoquena não se observa um carste típico, mas com algumas caracteristicas isoladas, como dolinas, sumidouros e ressurgências, raramente associadas a cavernas. Karmann \& Sánchez $(1979,1986)$ colocam também que as cavernas mostram um avançado grau de evolução, com grandes salöes de abatimento ao longo de planos de acamamento e juntas, que freqüentemente estão abaixo do nível d'água.

$\mathrm{Na}$ década de oitenta, após um longo período em que não há registros de publicações sobre o carste da região, os trabalhos são retomados com o "Projeto Grutas de Bonito" de Lino et al. (1984). Este projeto foi desenvolvido por um grupo de técnicos de diversas formações profissionais (arquitetos, geólogos, ecólogos, biólogos, etc.), que realizaram levantamentos topográficos, geológicos, biológicos, ambientais e turísticos de dezoito cavernas da região. Segundo Lino et al. (1984) os calcários da Formação Bocaina apresentam um relevo cárstico em adiantado grau de dissecação e aplainamento e na Formação Cerradinho ocorrem planícies menos desenvolvidas e vales mais entalhados. Descrevem a presença comum de sumidouros, apesar da 
predominância da drenagem superficial, nas quais formam buracos afunilados ou avens, que podem ocorrer associados aos leitos fluviais superficiais, que retomam seu curso superficial normal nas épocas mais chuvosas (Lino et al., 1984). Esta drenagem subterrânea não é penetrável, ou seja, não dá acesso a cavernas (Lino et al., 1984), mas mais recentemente a atividade de espeleo-mergulho tem mostrado que pelo menos partes dos condutos podem ser exploradas através do mergulho (Auler, 1991, 1992; Auler \& Boller, 1992). Lino et al. (1984) também descrevem a ocorrência de dolinas, principalmente na região ao sul de Bonito, como o caso da Lagoa Misteriosa'.

Boggiani et al. (1986) fazem a primeira citação no Brasil sobre a ocorrência de espeleotemas de nesquehonita, associados a aragonita, hidromagnesita e calcita, presentes na Gruta do Lago Azul como coralóides na forma de "couve-flor" e coloração que varia do amarelo claro ao alaranjado, sendo esta associação mineral registrada em várias cavernas estrangeiras.

Em 1990 uma expedição italiana explorou grutas na região do Assentamento Guaicurus, mapeando 6 cavernas denominado-as de MS-1 a MS-6 (Imperio \& Pezzolato, 1991). A caverna denominada MS-1, segundo a planta, aparentemente está localizado como MS-3 no mapa topográfico de localização das cavernas e é a gruta atualmente cadastrada na Sociedade Brasileira de Espeleologia (SBE) como Gruta Guaicurus (MS-83).

Em 1991 uma equipe franco-brasileira realizou mergulhos na Gruta do Lago Azul, Gruta do Mimoso, no Abismo Anhumas e na Nascente do Rio Formoso, dentro do que se denominou "Expedição Bonito'91", que visou avaliar o potencial da área para o Espeleo-mergulho (Auler, 1991). Além da elaboração de croquis das grutas exploradas tentou-se também determinar a conexão do Abismo Anhumas com a Gruta do Lago Azul, por estas estarem próximas, mas não foram encontrados condutos laterais no lago do abismo; foi também explorada uma gruta seca, a Gruta da Pitangueiras, de padrão labiríntico.

Outra expedição franco-brasileira foi realizada em 1992, na "Expedição francobrasileira Bonito'92", onde o trabalho de exploração subaquática foi expandido e foram exploradas e mapeadas as porções submersas das Grutas do Lago Azul, Gruta do Mimoso, Abismo Anhumas, nascente do Rio Formoso e Lagoa Misteriosa (Auler, 1992; Auler \& Boller 1992). Na Gruta do Lago Azul foram encontradas ossadas de animais do Pleistoceno. Em 1992, os franceses participantes da "Expedição Bonito'92" fizeram uma publicação em seu pais intitulada "Plonger dans la Prehistoire Bresilienne" (Mergulho na

\footnotetext{
${ }^{1}$ Recentemente mergulhos nesta lagoa chegaram a profundidades de mais de 100 metros.
} 
Pré-História Brasileira, Rosello et al., 1992) na qual eles divulgam a região de Bonito para a França, e as descobertas de ossadas, que, segundo informação verbal do Prof. Castor Cartelle da UFMG - Universidade Federal de Minas Gerais, com base em informações dos videos realizados na Expedição, seriam de Eremotherium, Smilodon e Glyptodon, mamíferos do Pleistoceno.

Gnaspini et al. (1994) cadastraram e topografaram 21 cavernas na Provincia Espeleológica da Serra da Bodoquena, onde agruparam as cavernas em cinco regiões com diferentes tipologias, fazendo também um levantamento faunistico. Neste trabalho, foi apresentada a topografia, incompleta, da Gruta Pitangueiras com $532 \mathrm{~m}$ de desenvolvimento, sendo esta considerada a maior caverna conhecida do Mato Grosso do Sul. Estes autores também citam que a região ainda é muito pouco explorada, sendo que a exploração de cavernas motivou-se por atrativos turísticos, mais centrada no espeleo-mergulho.

Um dos trabalhos mais recentes é de Ayub et al. (1996) realizado dentro da denominada Expedição Bonito'95/PROJETO AKAKOR. Esta expedição contou com 66 participantes em uma equipa "italo-brasileira" e contou com profissionais nas áreas de geologia, mergulho, biologia, medicina e de turismo (guias), sendo realizados exploração e topografia de 21 cavernas (Ayub et al., 1996). Neste trabalho, Ayub et al. (1996) sugerem, de maneira preliminar, a existência de dois grandes tipos de cavernas: um mais comum (ou mais conhecido) de grandes salōes de abatimento e outro de cavernas menores e de origem vadosa. Estes dois tipos de cavernas parecem estar distribuídos grosso modo em duas faixas $\mathrm{N}$-S, sendo o primeiro localizado na porção oriental da serra, e o segundo na porção ocidental, que aparentemente são condicionadas estruturalmente.

Recentemente estudos paleontológicos estão em andamento pelo pesquisador Leandro Salles, no Buraco do Japonês (ou Fósseis) (Salles et al., 2003) e na Nascente do Rio Formoso.

As prospecções espeleológicas acima relatadas aliadas aos resultados da presente pesquisa permitem concluir que a incidência de cavernas é baixa na Serra da Bodoquena, considerando a grande extensão de rochas carbonáticas na área. Além do reduzido número, as cavernas da Serra da Bodoquena também se caracterizam pelo pequeno desenvolvimento planimétrico, quando comparadas ao contexto espeleológico do Brasil. 


\subsection{Espeleometria}

Das 87 cavernas cadastradas na Sociedade Brasileira de Espeleologia na região da Serra da Bodoquena temos apenas 33 cavernas mapeadas (38\%), sendo 20 por trabalhos anteriores e 13 cavernas mapeadas neste trabalho, e as outras $54(62 \%)$ não possuem mapas ou apresentam apenas croquis. Alguns dados espeleométricos, sobre as cavernas mapeadas ou apenas com croquis, estão resumidos na Tabela 5.1 .

Tabela 5.1: Dados espeleométricos das cavernas mapeadas ou com croquis da Serra da Bodoquena.

\begin{tabular}{|l|c|c|}
\hline $\mathrm{N}^{\circ}$ de cavernas cadastradas & 87 & Até julho de 2004 \\
\hline $\mathrm{N}^{\circ}$ de cavernas mapeadas & 33 & (mapas bons) \\
\hline Desenvolvimento total & 14728,4 & \\
\cline { 1 - 2 } Desenvolvimento médio & 213,5 & 69 cavernas \\
\hline Desnivel médio & 29,9 & 65 cavernas \\
\hline
\end{tabular}

Percebe-se pelos dados apresentados na Tabela 5.1 que as cavernas mapeadas representam um pequeno percentual em quantidade e desenvolvimento em relação ao panorama geral das cavernas brasileiras. Chama a atenção o baixo valor de desenvolvimento médio das cavernas em contraposição a um desnível médio mais elevado. Auler et al. (2001a) chama a atenção ao fato da região da Serra da Bodoquena possuir um desnivel médio elevado, comparável aqueles do Vale do Ribeira (SP.PR), sugerindo ambiente com taxa de soerguimento semelhante ao Ribeira e elevado em relação aos ambientes cársticos mais estáveis, como é o caso das coberturas cratônicas do Grupo Bambuí.

Houve poucos projetos de mapeamento e exploração de cavernas na região, comparado a outras regiões do Brasil, o que dificulta uma análise mais objetiva. Porém todos os projetos existentes na região chamam a atenção para o fato de que na Serra da Bodoquena de fato não ocorre grande quantidade de cavernas, ou seja, a densidade de cavernas é baixa, e também com baixo desenvolvimento médio. Por outro lado a quantidade de cavernas submersas penetráveis é maior que em outras regiões, sendo que possivelmente os maiores sistemas de cavernas da Serra da Bodoquena devem ser os submersos, que ainda estão no início da exploração e mapeamento.

No Anexo 3 é apresentada uma listagem das cavernas da Serra da Bodoquena cadastradas na SBE, com algumas informações básicas. Algumas cavernas mesmo cadastradas não possuem coordenadas, o que impossibilita seu uso em pesquisa.

Apresenta-se no Anexo 6 os mapas completos das cavernas utilizadas no estudo dos padrões morfológicos e espeleogênese. 
Podemos notar que existem dois grandes grupos de cavernas na região: um ainda com a morfologia original preservada e outro com morfologia modificada por abatimento (Tabela 5.2). Como na região as cavernas com lagos formadas por abatimento são mais freqüentes, elas sempre foram as mais visitadas e exploradas, ficando em segundo plano as cavernas com morfologia original. Também se soma o fato destas cavernas estarem mais próximas à cidade de Bonito, que sempre foi o ponto de partida das expedições espeleológicas. A "Província Espeleológica da Serra da Bodoquena" definida por Karmann \& Sánchez (1986) é composta por cavernas que mostram um avançado grau de evolução, com grandes salões de abatimento ao longo de planos de acamamento e juntas, que freqüentemente estão abaixo do nivel d'água. Na verdade este padrão de cavernas é comum, bastante representativo em termos de volume, e por isso, é o mais explorado e mapeado, mas não é o único.

As cavernas com morfologia original preservada são aquelas que podem ser utilizadas numa análise de padrões morfológicos de cavernas. Sendo assim, enfatizouse nesta pesquisa o mapeamento das cavernas com morfologia original preservada.

Atualmente são reconhecidos pelo menos três padrões morfológicos principais que se distribuem em alguns compartimentos geomorfológicos especificos:

- Salōes de abatimentos;

- Cavernas em rede;

- Cavernas meandrantes.

A classificação dos padrões morfológicos se baseou nas propostas de Palmer (2000) e Lauritzen \& Lundberg (2000), entre outros, e sugestōes desta pesquisa, onde a geometria e morfologia dos condutos deverá ser utilizada para interpretar características do aqüífero cárstico atual. 
Tabela 5.2: Cavernas utilizadas na análise dos padrões morfológicos. Em cinza grutas com localização exata desconhecida.

\begin{tabular}{|c|c|c|c|}
\hline No SBE & Nome & Rio ou Lago & Tipo* \\
\hline 2 & Gruta do Lago Azul & Lago & $\overline{S A}$ \\
\hline 3 & Gruta Nossa Senhora de Aparecida & 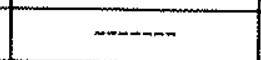 & SA \\
\hline 4 & Abismo Anhumas & Lago & $\mathrm{SA}$ \\
\hline 5 & Gruta Morro do Mateus & $-\ldots$ & MO \\
\hline 9 & \begin{tabular}{|l|} 
Gruta São Miguel \\
\end{tabular} & $+\cdots$ & $\mathrm{SA}$ \\
\hline 10 & Gruta Jaraguá & $-\cdots$ & SA \\
\hline 11 & Buraco das Araras & 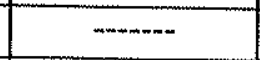 & DO \\
\hline 12 & Gruta do Mimoso & Lago & SA/MO \\
\hline 14 & Gruta João Arruda & $-\ldots$ & SA/MO \\
\hline 15 & Gruta do Curé & $-\cdots$ & SA \\
\hline 18 & Gruta do Pindó & $-\cdots$ & MO \\
\hline 33 & Nascente do Rio Formoso & $\begin{array}{l}\text { Ressurgência } \\
\text { subaquática }\end{array}$ & MO \\
\hline 38 & Gruta Pitangueiras & $-\cdots$ & MO \\
\hline 43 & Gruta Lagoa Misteriosa & Lago & SA/DO \\
\hline 50 & Gruta do Antenor & - n- & MO \\
\hline 51 & Gruta Cateto Sumido & $-\ldots$ & MO \\
\hline 52 & Gruta Duas Peladas & $-\cdots$ & MO \\
\hline 60 & Gruta Córrego Seco & $-\cdots$ & SA/MO \\
\hline 62 & Gruta da Pata & $-\cdots$ & MO \\
\hline 64 & Gruta Fazenda Serradinho & 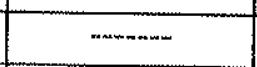 & MO \\
\hline 65 & Gruta do Periquito & - & SA/MO \\
\hline 66 & Gruta Casa de Pedra & - & $S A$ \\
\hline 67 & Gruta Dom Bosco & - & $\widehat{S A}$ \\
\hline 69 & Gruta Fazenda América & $-\cdots$ & $S A$ \\
\hline 73 & Gruta Opossum & Lago & $S A$ \\
\hline 79 & Nascente da Ceita-Corê & $\begin{array}{l}\text { Ressurgência } \\
\text { subaquática }\end{array}$ & MO \\
\hline 80 & Gruta Beija-Flor & Rio & MO \\
\hline 82 & Gruta Califórnia & $\begin{array}{c}\text { Sumidouro } \\
\text { não acessivel }\end{array}$ & $\mathrm{MO}$ \\
\hline 83 & Gruta Guaicurus & $-\cdots$ & MO \\
\hline 85 & Gruta Urubu Rei & Ressurgência & MO \\
\hline 86 & Gruta da Onça & $-\cdots$ & MO \\
\hline 88 & Gruta do Haroldo & 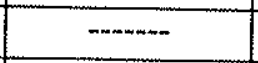 & MO \\
\hline 89 & Gruta Cinco de Ouros & Lago & MO \\
\hline 90 & Gruta Manoel Cardoso & Lago & MO \\
\hline 91 & Gruta Benedita & - & MO \\
\hline
\end{tabular}


5.3. Geoespeleologia

Os resultados obtidos através do mapeamento de cavernas e mapas disponíveis permitem esboçar uma relação entre as unidades de relevo definidas neste estudo e os tipos morfológicos dominantes das cavernas (Figura 5.1). 


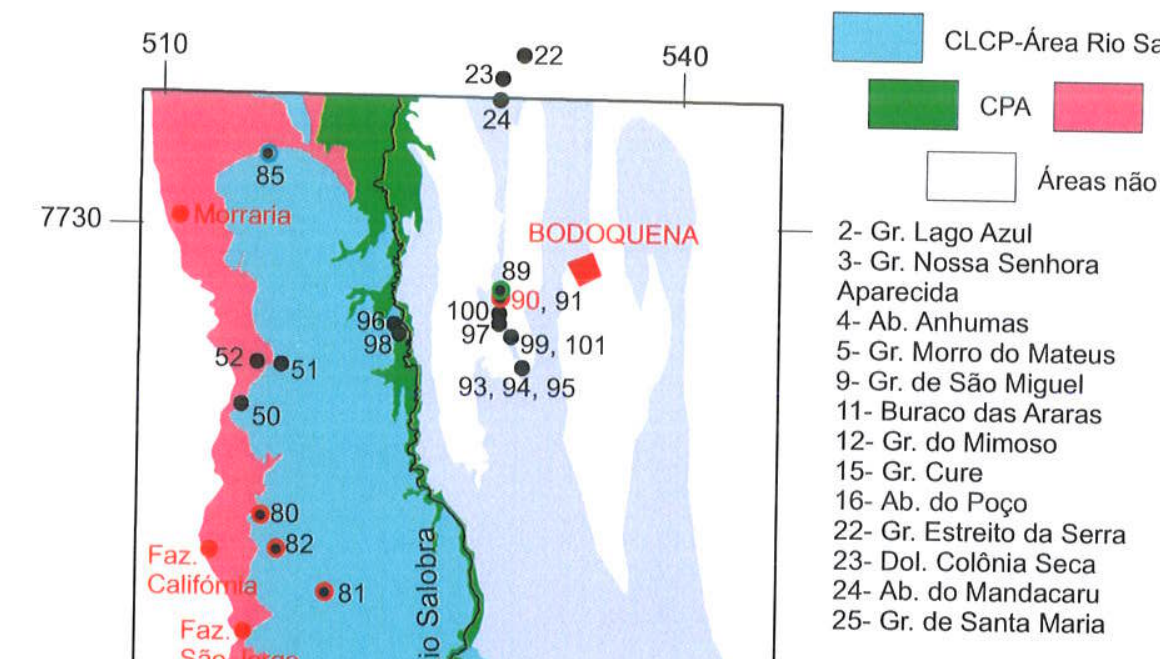

CLCP-Área Rio Perdido

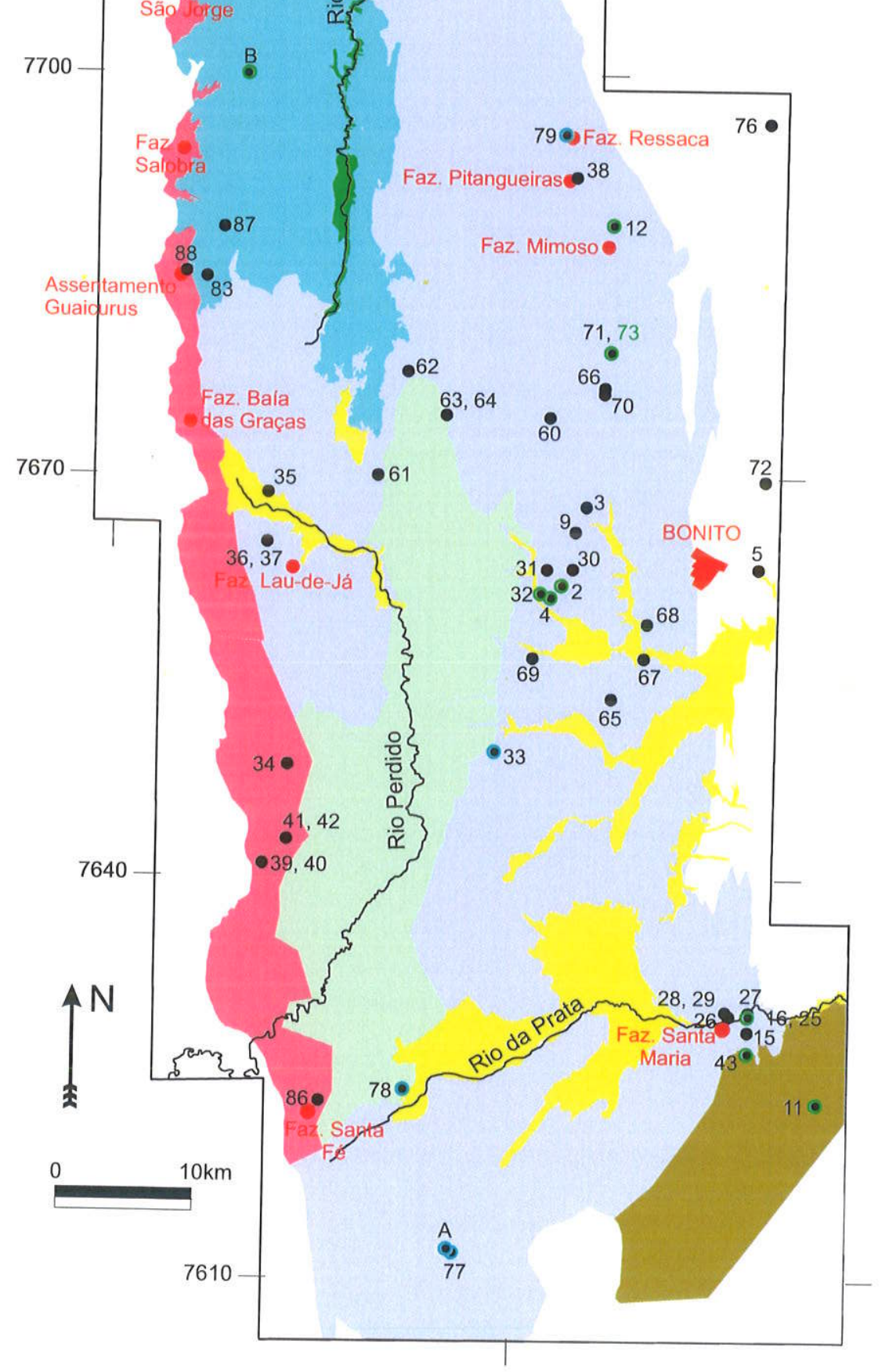

40- Gr. Curvelinho

41- Toca Mestiça de Baixo

42- Toca Mestiça de Cima

43- Gr. Lagoa Misteriosa

50- Gr. do Antenor

51- Gr. Cateto Sumido

52- Gr. Duas Peladas

60- Gr. Cór. Seco

61- Gr. Casa Nova

62- Gr. da Pata

63- Ab. Corpal

64- Gr. Faz. Serradinho

65- Gr. do Periquito

66- Gr. Casa de Pedra

67- Gr. Dom Bosco

68- Gr. Monte Cristo

69- Gr. Fazenda América

70- Gr. da Coruja

71- Gr. das Borboletas

72- Gr. Faz. Santo Antonio

73- Gr. Opossum

76- Gr. Taboquinha

77- Buraco do Japonês ou Fósseis

78- Buraco das Abelhas

79- Nasc. do Ceita-Curê

80- Gr. Beija Flor

81- Gr. Toca da Onça

82- Gr. Califórnia

83- Gr.Guaicurus

85- Gr. Urubu Rei

86- Gr. da Onça

87- Gr. José Cesário

88- Gr. do Haroldo

89- $\mathrm{Gr}$. Cinco de Ouros

90- Gr. Manoel Cardoso

91- Gr. da Benedita

93- Gr. do Alex

94- Gr. do Alex 2

95- Gr. do Alex 3

96- Cav. Santa Luzia

97- Ab. Coronel Chico Mineiro

98- Cav. Betel

99- Cav. Quatro Irmãos

100- Cav. Tiago

101- Cav. Quatro Irmãos 2

A-Buraco do Sapo

B- Buraco do Bebedouro

- Cavernas

- Nascente

- Sumidouro

- Caverna com lago

- Localidades principais

Figura 5.1: Mapa de distribuição de cavernas em relação às unidades morfológicas. Numeração corresponde ao cadastro na Sociedade Brasileira de Espeleologia (SBE). 


\subsubsection{Cavernas nas unidades CPA e CLCP (Área Rio Salobra)}

\subsubsection{1. Área Morraria}

Distribuição

Neste setor investigou-se somente a Gruta Urubu Rei (Figura 5.2), localizada a noroeste da área estudada na região de Morraria (Figuras 4.12 e 5.1). Esta caverna representa a nascente do principal afluente da margem direita do Córrego Serra. A entrada da caverna situa-se a $150 \mathrm{~m}$ acima do leito do Córrego Serra (Figuras 4.12E e 4.18D).

Morfologia e geologia

A Gruta Urubu Rei desenvolve-se em calcário estratificado com mergulho subhorizontal sobreposto a metapelitos (folhelhos vermelhos). Com $473 \mathrm{~m}$ de desenvolvimento planimétrico e desnível de $3,7 \mathrm{~m}$, possui morfologia em planta de conduto meandrante com sinuosidade angulosa, cujos segmentos estão orientados segundo as direções N11E a N20E, N70E a N83E, N75W a N86W, N15W e N45W, as quais seguem os principais conjuntos de fraturas ao longo da caverna (Figura 5.2). Em seção transversal os condutos são predominantemente retangulares, localmente elípticos com larguras entre 2 a $7 \mathrm{~m}$ e alturas entre 1,5 a $4 \mathrm{~m}$. Este conduto principal é interceptado no teto por fendas verticais em pelo menos 5 pontos. Estas fendas com abertura em torno de $1 \mathrm{~m}$ e altura observada de no mínimo $20 \mathrm{~m}$ apresentam preenchimento parcial de calcita secundária e direções N10E, N35W e N60E. Sua orientação é ora paralela em relação ao conduto principal, e ora obliqua com ângulos de 30 a 80 graus.

O curso d'água desta caverna é alimentado principalmente através de uma fenda sub-vertical, com largura de $50 \mathrm{~cm}$, profundidade observada de $7 \mathrm{~m}$ e direção N33E, que intercepta o piso do conduto principal, próximo ao fundo da caverna (Figura 5.2).

\section{Espeleogênese}

A iniciação do conduto principal da Gruta Urubu Rei é atribuída a ampliação freática ao longo da intersecção do acamamento sub-horizontal com as fraturas subverticais de direção N10E, N30E a N35E, N60E, N10W e N35W, seguida pela fase de entalhamento vadoso responsável pela morfologia de seção retangular dominante neste conduto. A evolução do conduto principal da Gruta Urubu Rei está associado ao desenvolvimento de um nivel de condutos conforme pode ser visto na escarpa da 
margem direita do Córrego Serra, onde se observa uma série de condutos alinhados segundo o traço sub-horizontal do acamamento (Figura 5.3A).

A origem das fendas sub-verticais que interceptam o teto deste conduto é atribuida ao encontro de fendas profundas do epicarste (karren) com o conduto principal da caverna. Estima-se uma espessura de cerca de $50 \mathrm{~m}$ de calcário acima da caverna. A presença destas fendas é evidenciada na observação de fotografias aéreas em escala 1:60.000.

Por outro lado a fenda sub-vertical que intercepta o piso do conduto principal é interpretada como um conduto freático ativo com fluxo de água ascendente semelhante ao modelo de "chaminés freáticas" descritas por Ford et al. (2000) na caverna Castleguard (Canadá). Este conduto ascendente é condicionado por um fratura N33E/sub-vertical observada no teto do conduto principal.

A recarga deste sistema cárstico é de natureza autogênica, pois é realizada através de um conjunto de bacias poligonais desenvolvidas sobre o interflúvio carbonático (Unidade CLCP). 


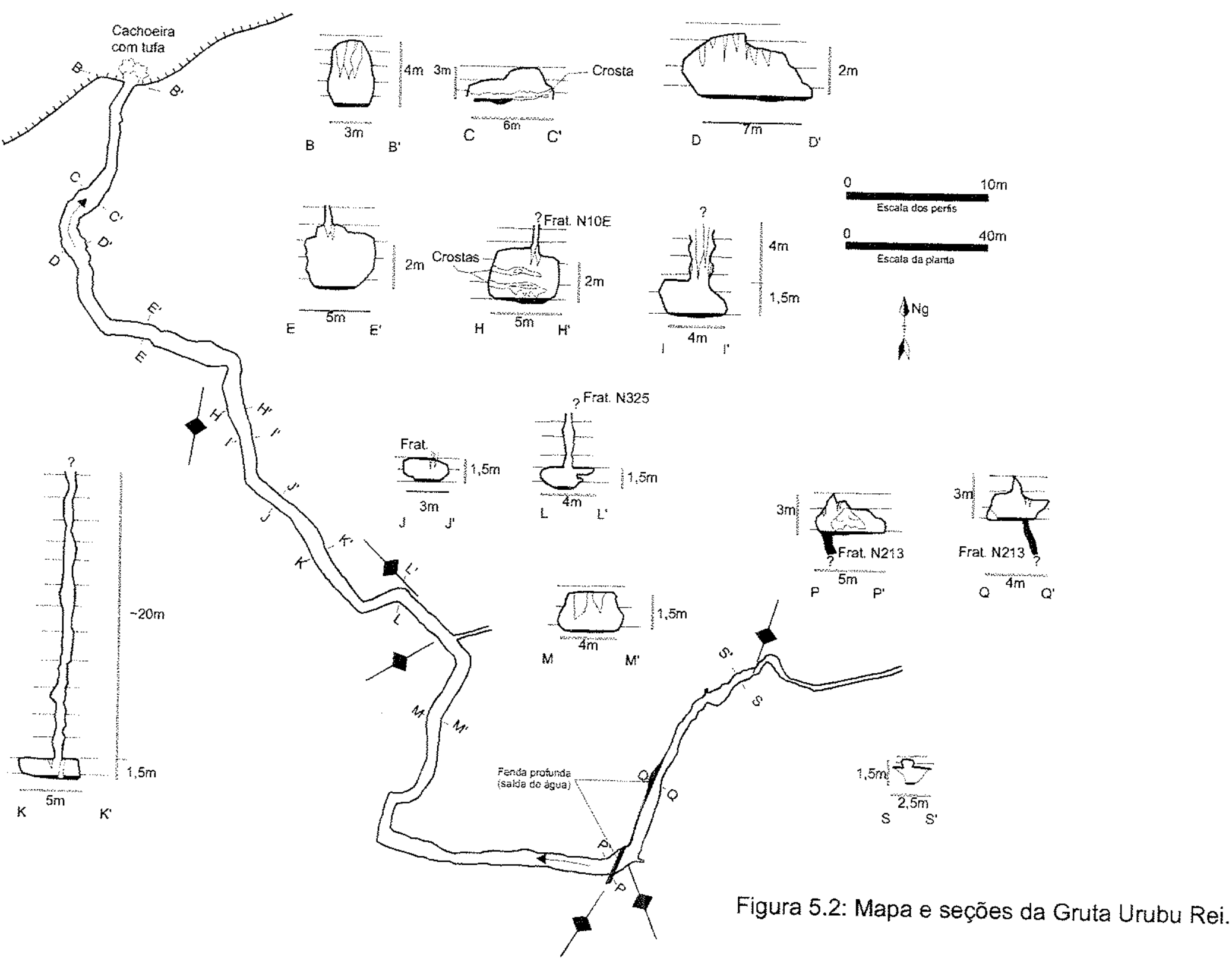



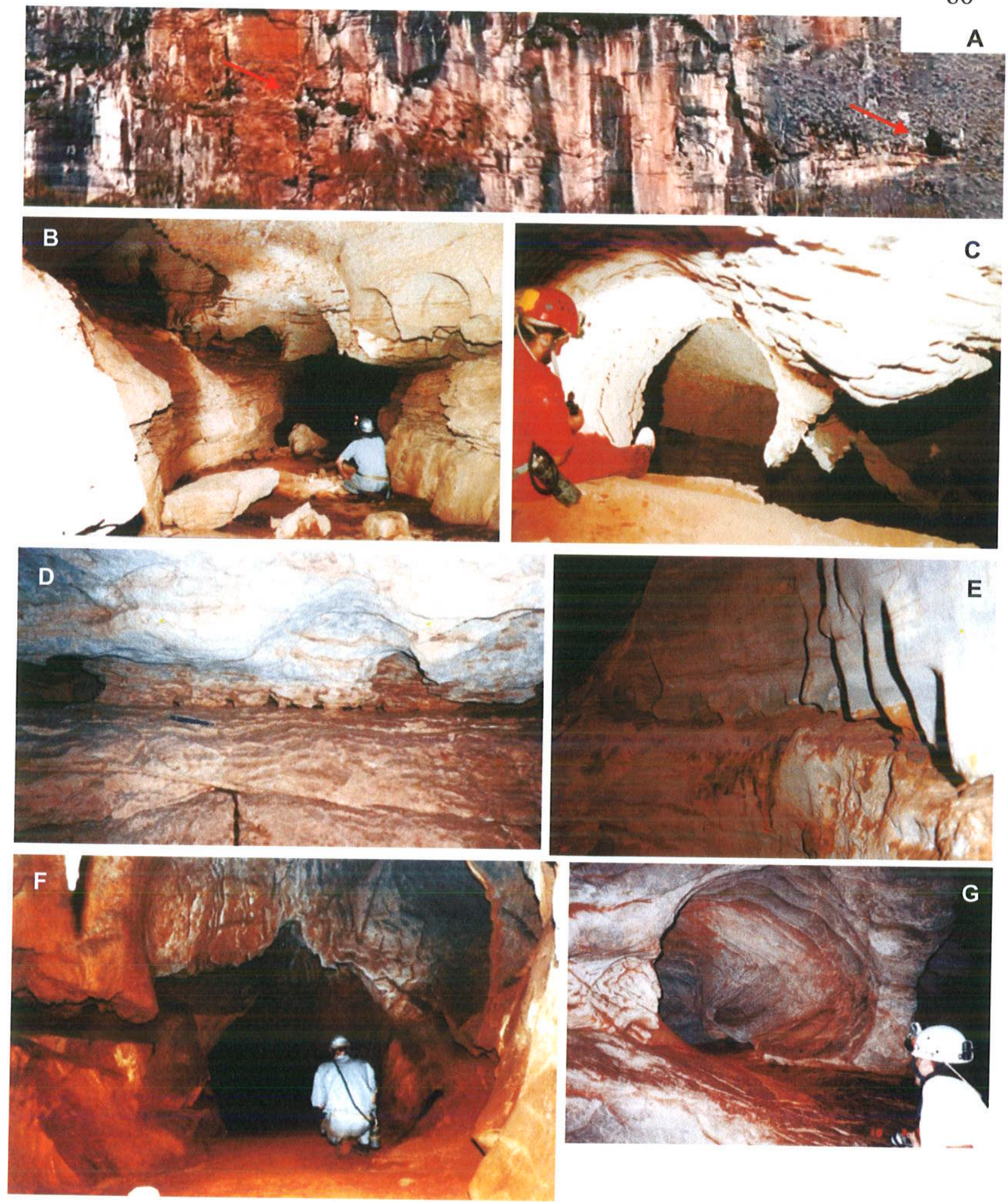

Figura 5.3: A- Nível de condutos na escarpa da margem direita do Córrego Serra. Gruta Califórnia: B- Galeria principal de seção retangular com pendants e condutos secundários em rede anastomosada (bases 20 e 27, Figura 5.6 perfil E-F); C- Detalhe condutos secundário com seção semi-circular demarcados por pendants (base 27); D-

Protocondutos em rede anastomosada desenvolvidos em plano de acamamento. E-

Protocondutos em rede anastomosada desenvolvidos em plano de acamamento na

Gruta do Haroldo. Gruta da Onça: F- Conduto principal com condutos laterais (à esquerda) em rede anastomosada (base 09, Figura 5.8 perfil C-D); G- Detalhe de um dos condutos secundários da rede anastomosada. 


\subsubsection{Cavernas nas Unidade ZT e CLCP (áreas Rio Salobra e Perdido)}

\subsubsection{1. Área Fazenda Califórnia}

\section{Distribuição}

A área denominada Fazenda Califórnia localiza-se no oeste da Serra da Bodoquena (Figura 4.11). Neste setor investigou-se as cavernas Beija Flor e Califórnia (Figuras 4.11A e 5.1). Na Gruta Toca da Onça foi realizado apenas um mergulho com observações preliminares. Estas cavernas representam exemplos de sistemas cársticos com contribuição de recarga alogênica, pois estão associados a vales cegos, com bacias de captação sobre granitos, metarenitos e metapelitos da Unidade ZT (Figuras 4.5A e 5.1 e Anexo 4).

\section{Morfologia e geologia da Gruta Beija Flor}

A Gruta Beija Flor desenvolve-se em calcário estratificado ondulado por dobras abertas, com direções de acamamento entre NO5E e N10E mergulhando de 20 a 50 graus para SE. Dobras apresentam atitudes de acamamento de N84W/12SW e N39W/09NE. Possui $177 \mathrm{~m}$ de desenvolvimento planimétrico parcial e $25 \mathrm{~m}$ de desnivel, sendo composta basicamente de um conduto simples meandrante, com sinuosidade no geral curvilinea (Figura 5.5). Apenas um trecho anguloso, no início da caverna, onde o conduto apresenta duas direções praticamente ortogonais, N55E e N40W (Figura 5.5). Por este conduto percorre um rio subterrâneo formando diversas cachoeiras. $O$ piso da caverna é composto ora de rocha e ora de sedimento arenoso, proveniente de fontes alóctones (metarenitos e granitos alterados). Em seção apresenta-se como um canyon meadrante na vertical e horizontal (Figura 5.5). Em certos trechos este canyon encontrase preenchido por calcita secundária (Figura 5.5).

\section{Morfologia e geologia da Gruta Califórnia}

A Gruta Califórnia desenvolve-se em calcário estratificado ondulado por dobras abertas, com direçōes de acamamento variando entre NE e NW, e mergulhos para NE ou SE (Tabela 5.3). Com $250 \mathrm{~m}$ de desenvolvimento planimétrico e desnivel de $15 \mathrm{~m}$, é dividida em dois compartimentos, do ponto de vista morfológico. Um salão de abatimento junto a entrada e um conjunto de condutos em rede no extremo leste da caverna (Figura 5.6). O salão de abatimento possui $125 \mathrm{~m}$ de eixo maior na direção $\mathrm{N} 50 \mathrm{E}$, cerca de $40 \mathrm{~m}$ de largura e altura atingindo $10 \mathrm{~m}$ (Figura 5.6). O setor em rede é caracterizado por um conduto principal de $50 \mathrm{~m}$ na direção N70W conectado na sua parte superior a um conjunto de condutos menores de direções N37E e N15W (Figura 
5.6). O conduto principal possui seção retangular na porção inferior e arredondada no teto (com pendants e half tubes) (Figuras 5.3B e 5.5). Os condutos menores, com diâmetros decimétricos a métricos, caracterizam uma rede anastomosada, com piso plano desenvolvido sobre a superficie de estratificação, onde os condutos com seção semi-circular são demarcados por pendants (Figuras 5.3C e 5.5).

\section{Espeleogênese da Gruta Beija Flor}

Não se observam evidências da fase de iniciação nesta caverna. A morfologia verificada de canyons meandrantes reflete um entalhamento vadoso controlado em parte por fraturas sub-verticais (Tabela 5.4). Na entrada se observa que o conduto é controlado por uma zona de cisalhamento, posteriormente seguindo fraturas NE, onde forma o trecho anguloso (Tabela 5.4).

\section{Espeleogênese da Gruta Califórnia}

Existe uma fase de iniciação que é condicionada por uma rede de linhas fluxo que se desenvolve sobre a superficie do acamamento e predominantemente guiadas pelo sistema de fraturas principais, de direções NS, EW e NE, com mergulho sub-vertical para oeste (Tabela 5.5). A iniciação é atribuída a um sistema anastomosado com anastomose desenvolvida preferencialmente sobre plano de estratificação (Figura 5.3D), onde um filme de sedimentos finos que protegeu a base, condicionando a ampliação da rede anatomosada ampliando o teto, formando os condutos com seção semi-circular (half tubes). Este padrão morfológico assemelha-se ao descrito na literatura como bedding-plane anastomoses (Figura 5.4, Ford \& Williams, 1989; Lauritzen \& Lundberg, 2000).

Com ampliação progressiva desta rede ocorreu o desenvolvimento freático que acaba conectando pela base parte dos tubos gerando os pendants que resultou na rede anastomosada parcialmente acessivel (Figura 5.3B). Este desenvolvimento freático ocorreu em gradiente hidráulico baixo indicado pela rede anastomosada.

Com o rebaixamento do nivel d'água inicia-se uma concentração de fluxo em condutos de maior eficiência hidráulica, da rede anastomosada, instalando-se um regime de fluxo turbulento que foi responsável pelo entalhamento vadoso, que gerou o conduto principal retangular.

O salão da entrada é resultado do abatimento desta rede anastomosada evidenciado pela sua direção preferencial, coincidente com o conduto principal, e por testemunhos isolados da rede anastomosada em trechos laterais no salão, junto ao teto. 
Tabela 5.3: Medidas de acamamento na Gruta Califórnia.

\begin{tabular}{lcc} 
NS/40E & N90E/27NE & N20W/20NE \\
N05E/45SE & N90E/18N & N40W/15NE \\
N15E/40SE & N80W/25NE & N60W/22NE \\
N26E/22SE & & subhoriz./NE \\
\hline
\end{tabular}

Tabela 5.4: Medidas de fraturas na Gruta Beija Flor.

\begin{tabular}{ccc}
\hline NS & N15W & N65W/vert. \\
$N 05 W$ & $N 35 W$ & N70W/80SW \\
N10E/85NW & N45W/subvert. & N65E/vert. \\
N15E & N55W/80SW & N70E/vert. \\
NS/vert. (zona de cisalhamento) & N60W/80SW & \\
\hline
\end{tabular}

Tabela 5.5: Medidas de fraturas na Gruta Califórnia.

\begin{tabular}{ccc}
\hline NST/70W & N05E/65NW & EW/subvert. \\
N05W/subvert. & N15E/70NW & N85W/75NW \\
N05W/70SW & N24E/subvert. & N80W/subvert. \\
N10W/subvert. & N35E/55SE & N80E/subvert. \\
N10W/subvert. & N45E/subvert. & \\
N10W/80SW & N48E//subvert. & \\
N15W/80SW & N52E/subvert. & \\
N15W/75SW & N52E/70NW & \\
\hline
\end{tabular}

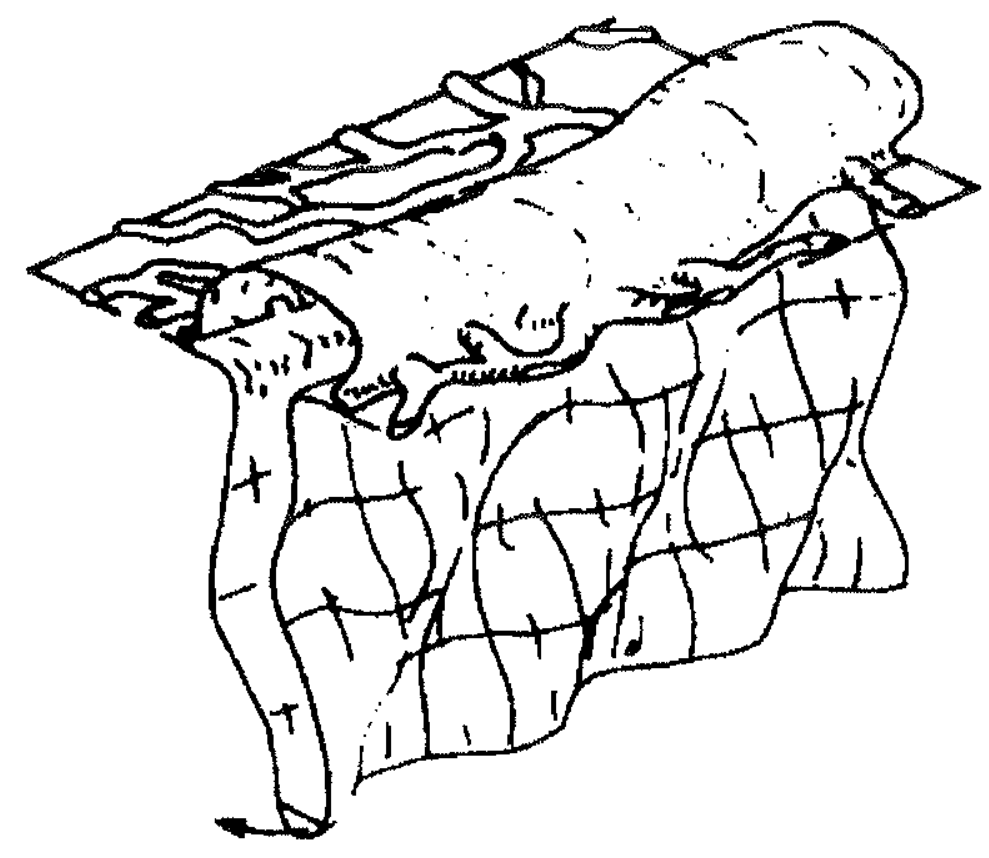

Figura 5.4: Modelo de canyon vadoso desenvolvido a partir de condutos anastomosados freáticos (Ford \& Williams, 1989). 

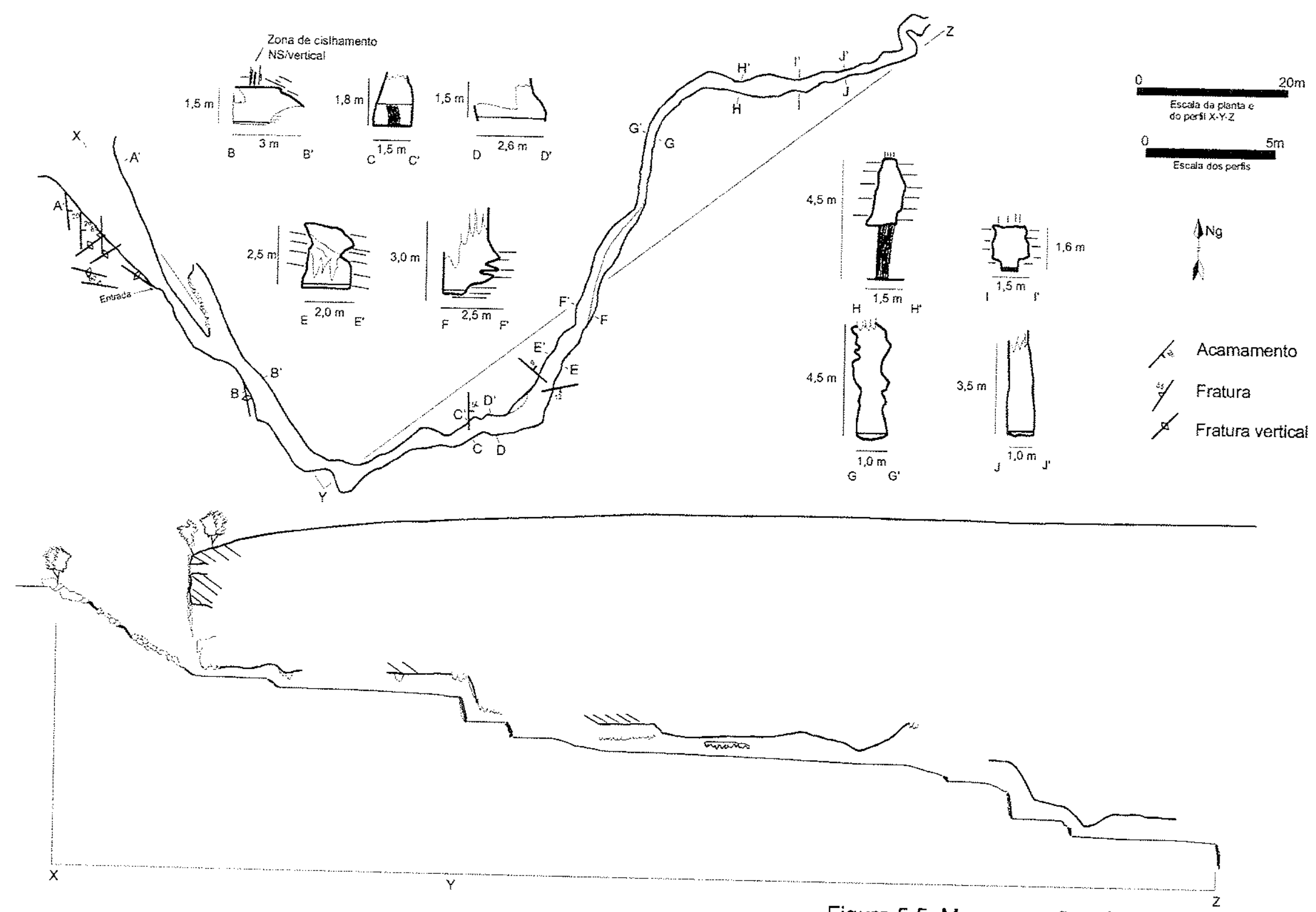

Figura 5.5: Mapa e seções da Gruta Beija Flor. 

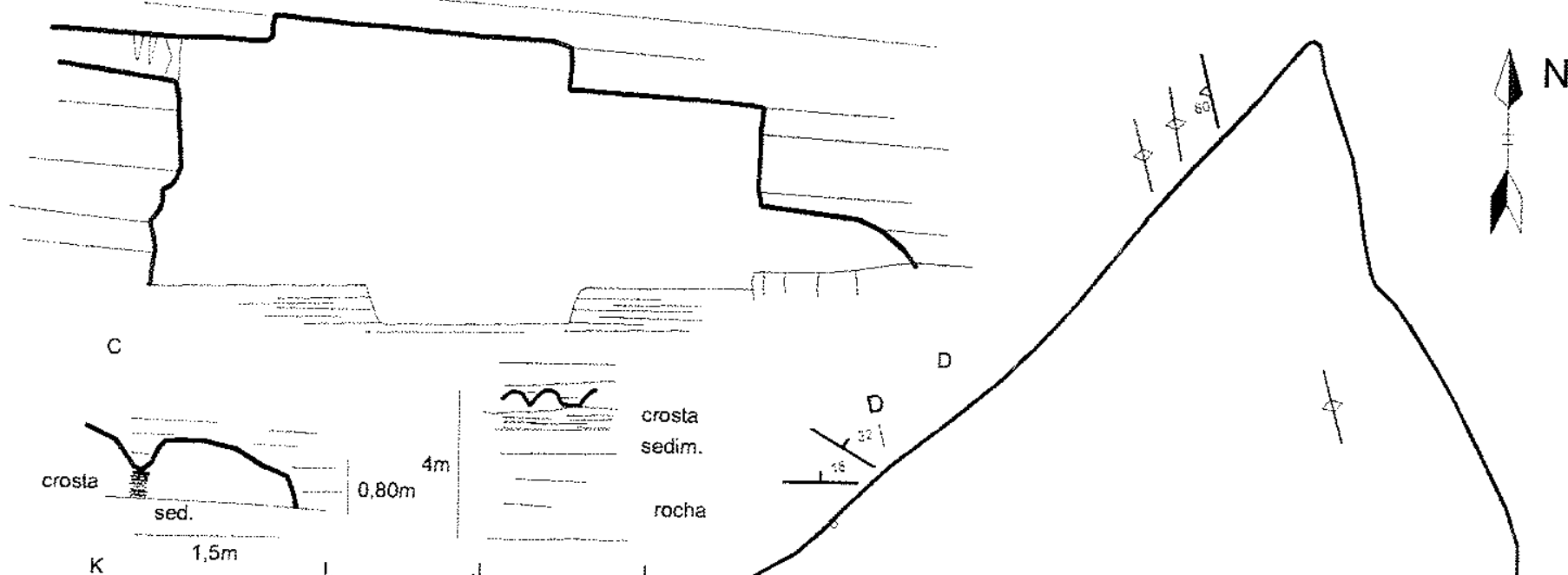

$\mathrm{Ng}$
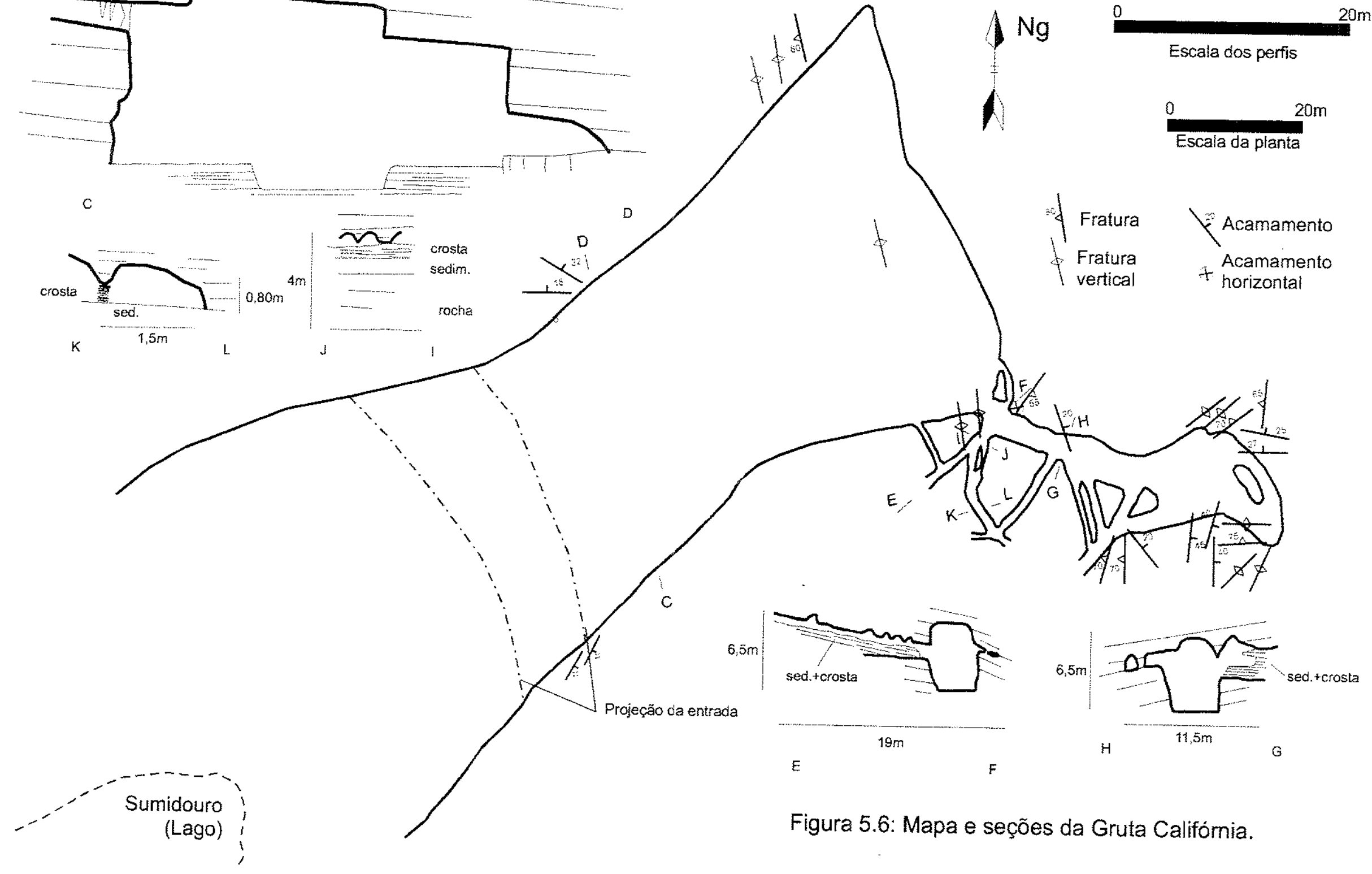

Figura 5.6: Mapa e seções da Gruta Califórnia. 


\subsubsection{2. Área Guaicurus}

\section{Distribuição}

Esta área situa-se no oeste da Serra da Bodoquena na região do Assentamento Guaicurus (Figuras 4.4, 4.13,5.1 e Anexo 4). Neste setor três grutas foram localizadas, sendo que apenas uma, a Gruta do Haroldo, foi utilizada para o estudo morfológico. As outras duas, as grutas Guaicurus e José Cesário, apresentam desenvolvimento muito pequeno. Além da Gruta Guaicurus as outras cinco grutas localizadas por Imperio \& Pezzolato (1991) não foram consideradas, pois são apresentados apenas croquis.

Aqui a área de captação da Unidade ZT é muito menor que na Área Fazenda Califórnia (Figura 4.4 e Anexo 4) e as cavernas são exemplos de condutos reliquiares de injeção alogênica.

A Gruta do Haroldo situa-se no alto de um morro testemunho de calcário da Unidade CLCP, $40 \mathrm{~m}$ acima das planícies da Unidade ZT (Figura 4.15E).

\section{Morfologia e geologia da Gruta do Haroldo}

A Gruta do Haroldo desenvolve-se em calcário estratificado ondulado por dobras abertas, com atitudes de acamamento entre N32E e N88E, com mergulhos de 07 a 38 graus geralmente para SE, e localmente para NW (Figura 5.7). Possui $172 \mathrm{~m}$ de desenvolvimento e $7 \mathrm{~m}$ de desnivel, sendo composta basicamente de um conduto principal meandrante anguloso, com condutos secundários conectando-se a ele. $\mathrm{O}$ conduto principal tem uma direção geral N51E, e seus meandros nas direções N27E, N16W, N09W, N38W e N22E (Figura 5.7). O piso é composto de sedimento argiloso. Em seção apresenta-se como um canyon meadrante, porém com a presença de cúpulas, modificando esta morfologia original (Figura 5.7).

\section{Espeleogênese}

Não se observa evidências da fase de iniciação desta caverna. Apenas em alguns pontos canais anastomosados, de pequena escala, desenvolvidos no acamamento em posição lateral ao conduto principal sugerem que a iniciação desta caverna, como outras da região, foi através de condutos anastomosados (Figura 5.3E). O que se observa hoje é que o canyon meandrante possui uma morfologia aparentemente vadosa, mas existe a possibilidade de ser um fragmento da rede anastomosada soterrada pelos sedimentos. O conduto principal é condicionado por fraturas de direções N40E a N52E com mergulhos de 50 a 80 graus para NW, com meandros que acompanham as direções de fraturas listadas na Tabela 5.6. 
Tabela 5.6: Medidas de fraturas na Gruta do Haroldo.

\begin{tabular}{|c|c|c|}
\hline N11ERONW & N12E/75SE & N03W/75NE \\
\hline N25E/7ONW & N16E/85SE & N06W/80NE \\
\hline N40E/80NW & N20E/85SE & $\mathrm{N} 33 \mathrm{~W} / 65 \mathrm{SW}$ \\
\hline N42E/80NW & N27E/85SE & N53W/65SW \\
\hline N50E/50NW & N46E/25SE & $\mathrm{N} 58 \mathrm{~W} / 75 \mathrm{SW}$ \\
\hline N52E/85NW & N60E/85SE & N63W/36NE \\
\hline N52E/55NW & N77E/85SE & N70W/90SW \\
\hline N76E/85NW & N84E/80SW & N73W/65NE \\
\hline N84E/65NW & & N78W/70NE \\
\hline N87E/85NW & & \\
\hline
\end{tabular}

\subsubsection{Cavernas na Unidade CLCP (Áreas Rio Perdido)}

\subsubsection{1. Área Fazenda Santa Fé}

Distribuição

Esta área situa-se na porção oeste da Serra da Bodoquena na região da Fazenda Santa Fé (Figura 5.1 e Anexo 2). Neste setor apenas a Gruta da Onça foi estudada.

Neste setor a área de captação alogênica é reduzida e a Gruta da Onça se encontra dentro da Unidade CLCP.

Morfologia e geologia da Gruta da Onça

Desenvolve-se em calcário estratificado com acamamento ondulado por dobras abertas, com atitudes médias de direção N52E e N82E, e mergulhos de 30 a 85 graus variando entre NW e SE. Localmente o acamamento tem direção N88W com mergulho variando entre 5 graus, para SW e 10 graus para NE (Figura 5.8). Possui $161 \mathrm{~m}$ de desenvolvimento e 13,7 m de desnível, sendo composta de um conduto principal meandrante curvilíneo, com condutos secundários (Figura 5.8). O conduto principal tem uma direção geral N31E e os condutos secundários possuem direções de N2E a N7E, N60E e N58W a N62W (Figura 5.8). Em seção apresenta contornos geralmente elípticos a retangulares, com 10 cúpulas distribuídas ao longo da caverna (Figura 5.8). Em um trecho da caverna ocorre uma galeria lateral em rede anastomosada ao longo de uma fratura, que forma um ângulo de 50 graus com o acamamento (Figuras 5.3F, G e 5.8 perfis C-D e I-J). 

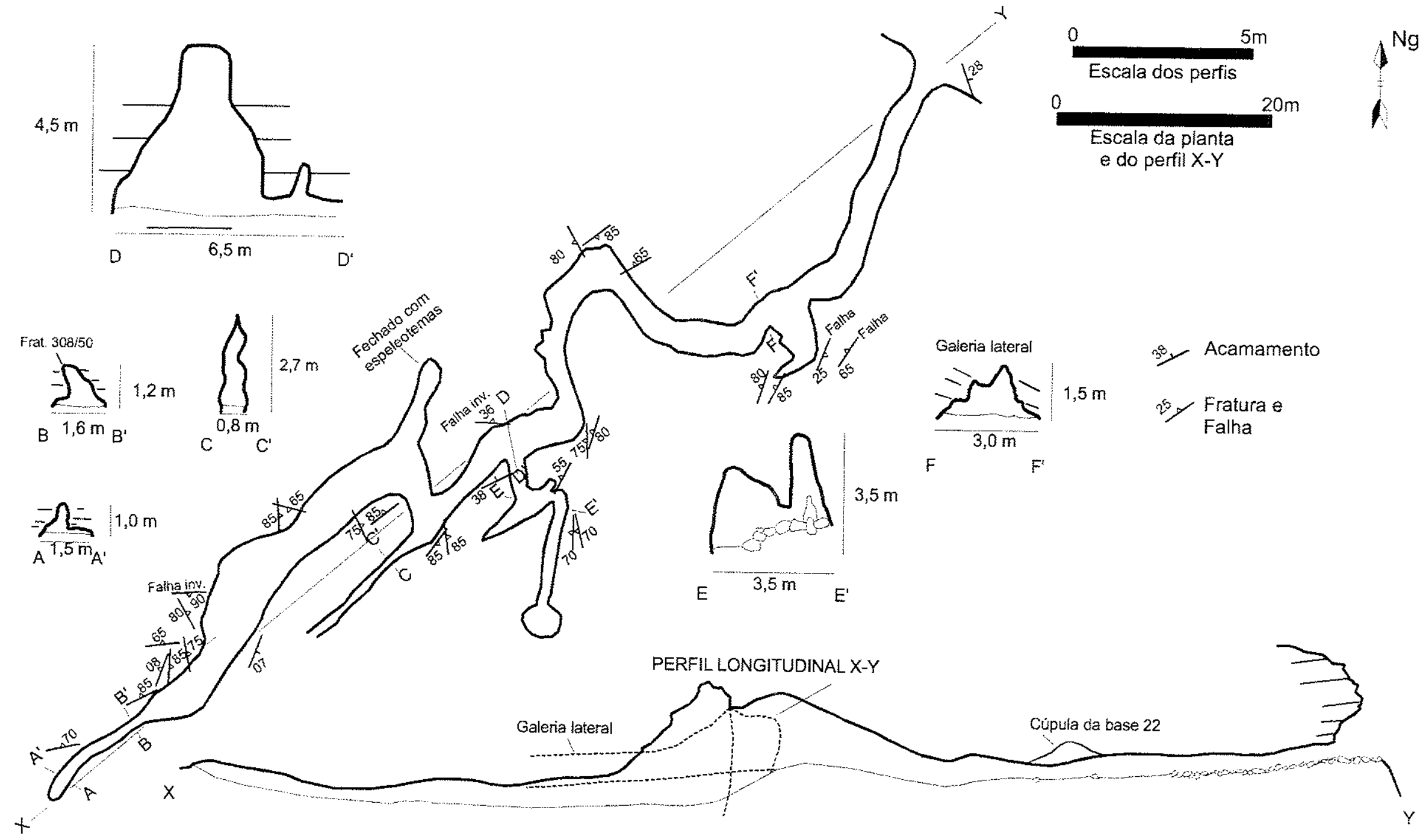

Figura 5.7: Mapa e seções da Gruta do Haroldo. 
Espeleogênese

A fase de iniciação nesta caverna é evidente apenas no trecho de rede anastomosada. Neste caso a anastomose freática se deu ao longo de fraturas, e não no acamamento como descrito em outras cavernas. A caverna apresenta predominantemente feições de um desenvolvimento em ambiente vadoso que gerou os condutos de seção elíptica a retangular. Modificações posteriores, ainda em ambiente vadoso, geradas por corrosão por condensação (condensation corrosion) são evidenciadas pelas cúpulas, que são as feições mais marcantes ao longo da caverna (Figura 5.8 perfil $X-Y$ ).

Tabela 5.7: Medidas de acamamento na Gruta da Onça.

$\begin{array}{lcc}\text { N88W/10SW } & \text { N72E/50NW } & \text { N72E/55NW } \\ \text { N88W/05NE } & \text { N82E/30NW } & \text { N72E/80NW } \\ \text { N62E/85NW } & \text { Sub-horiz. } & \text { N57E/80SE } \\ \text { N62E/80NW } & \text { N67E/80NW } & \text { N52E/75SE }\end{array}$

Tabela 5.8: Medidas de fraturas na Gruta da Onça.

\begin{tabular}{llll}
\hline N02E/20SE & N12E/vert. & N52E/80NW & \\
N02E/80SE & N377E/vert. & N62E/80SE & N73W/30SW \\
N02E/65SE & N52E/65SE & N62E/85SE & N88W/80NE \\
N12E/vert. & N52E/80NW & N62E/30SE & N08W/vert. \\
\hline
\end{tabular}




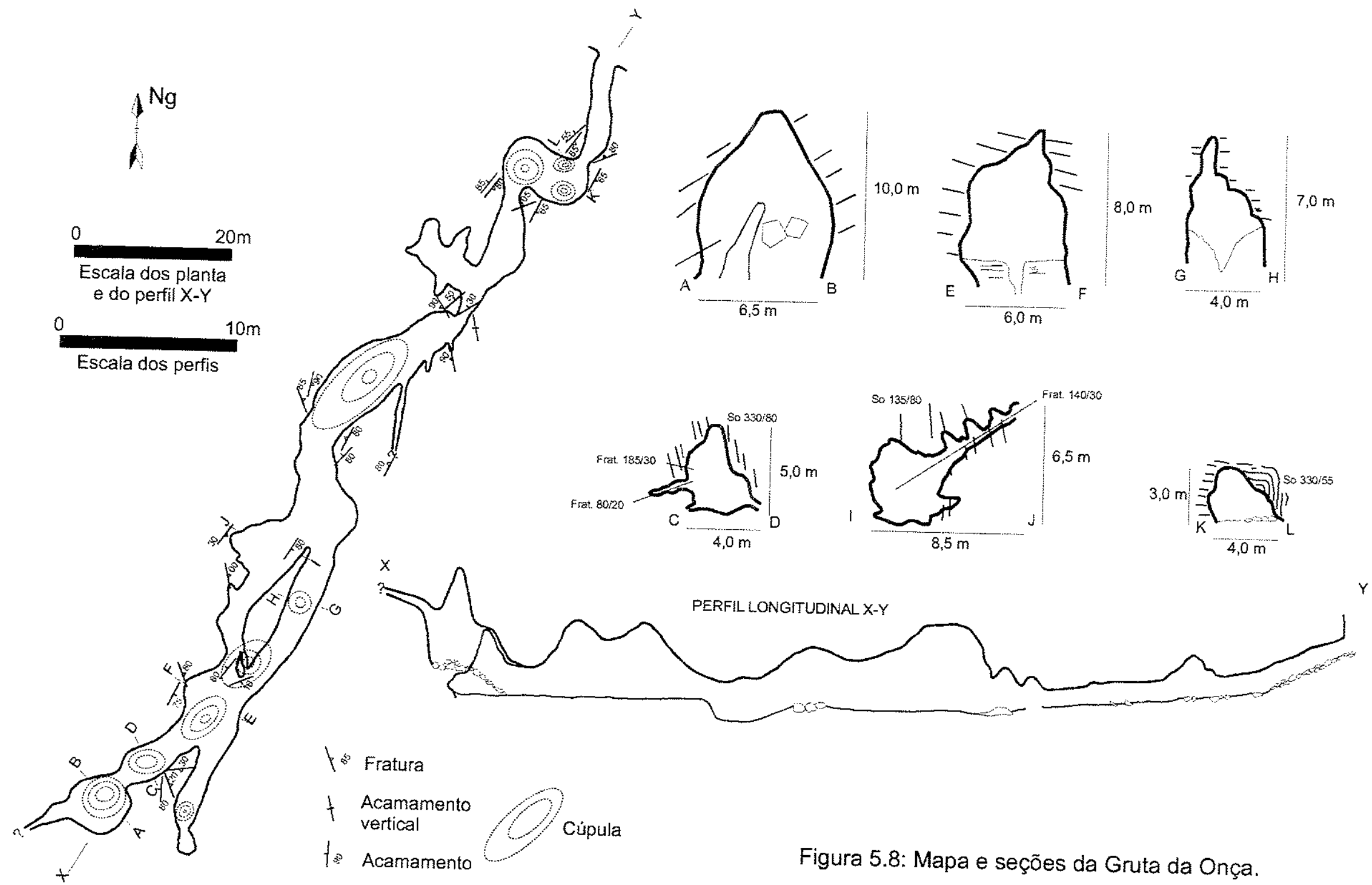




\subsubsection{Cavernas nas Unidade PCMR}

As grutas neste setor ocorrem nos morros residuais de dolomitos separados por planícies (Figura 5.1).

Os salões de abatimento ocorrem essencialmente na Unidade PCMR, nos dolomitos, em ambiente vadoso ou freático (submerso) com a presença de lagos (Figura 5.1) e espeleotemas vadosos submersos. São salões de abatimentos irregulares (aproximadamente elípticos) em planta, formando planos inclinados ou verticais em seção transversal, desenvolvendo-se em fraturas e acamamento.

A maioria destes salöes não possui morfologia original preservada, com raros trechos ou contornos em planta sugestivos de condutos originais, o que dificulta o estudo mais detalhado da origem destas cavernas. Não se trata de um padrão propriamente dito, mas sim de trechos preservados de padrões de condutos posteriormente abatidos. A importância destes salöes de abatimento reside no fato deles se encontrarem atualmente submersos, com indícios de fases onde trechos estavam em condições vadosas, como são os casos das grutas Mimoso e Anhumas, que possuem além de estalactites e estalagmites submersas, crostas e cones subaquáticos em grande quantidade. A importância destas variaçōes de nivel d'água serão discutidas no Capítulo 6.

Duas regiões se destacam com alguns exemplos deste padrão de cavernas: a da Gruta Lago Azul e a da Gruta Mimoso.

\subsubsection{1. Área Lago Azul}

\section{Distribuição}

$\mathrm{Na}$ área da Gruta Lago Azul, destacam-se, além desta, as cavernas Anhumas, Nossa Senhora Aparecida, Gruta São Miguel, Jaraguá e Fazenda América (Figura 5.1). As cavernas desta área encontram-se a oeste da cidade de Bonito, e se distribuem ao redor da caverna mais conhecida, a Gruta Lago Azul (Figura 5.1).

Nesta área predominam os salöes de abatimentos, porém duas grutas preservam parte da morfologia original, as grutas Periquito e do Portal (Figura 5.9), que não serão utilizadas para o estudo da morfologia das cavernas da área, pois além de serem pouco representativas, não se obteve informações geológicas destas. 
Morfologia e geologia das grutas Lago Azul, Anhumas, Nossa Senhora Aparecida, São Miguel, Jaraguá e Fazenda América

Os salões de abatimento desta área possuem forma irregular em planta, tendendo a elíptica, com exceção da Gruta do Periquito, que possui forma alongada (Figura 5.9). Os salões possuem dimensões variáveis, entre 224 a $120 \mathrm{~m}$ de eixo maior (Tabela 5.9). Possuem orientações de eixo maior também variadas, porém predominando direções entre N26W e N84W, com algumas exceções e também eixos menores a N42E a N65E (Tabela 5.9).

Em perfil apresentam-se como planos inclinados a verticais, seguindo fraturas ou acamamento.

Nesta área o acamamento apresenta-se dobrado com direções predominantes norte-sul e mergulhos variando para oeste e leste (Tabela 5.10).

Apresentam abundante deposição de diversas formas de espeleotemas, tanto vadosos quanto subaquáticos, conforme discutido no Capítulo 6.1.

Tabela 5.9: Dados de direção e dimensões dos salões da área da Gruta Lago Azul.

\begin{tabular}{cccc}
\hline Caverna & Orientações & Eixo maior $(\mathrm{m})$ & Eixo menor $(\mathrm{m})$ \\
\hline Lago Azul & N33W - eixo maior & 224 & 184 \\
& N65E - eixo menor & & \\
Nossa Senhora Aparecida & N32W - eixo maior & 144 & 143 \\
Anhumas & N84W - eixo maior & 120 & 86 \\
São Miguel & N26W - eixo maior & 180 & 90 \\
Periquito & N50E & Desenvoivimento: $80 \mathrm{~m}$ \\
Fazenda América & N42E - eixo maior & 120 & 48 \\
\hline
\end{tabular}


Tabela 5.10: Medidas de direção de acamamento (So) e fraturas das cavernas da área da Gruta Lago Azul. Dados extraídos de Ayub et al. (1996 - grutas Periquito e Faz. América) e de Lino et al. (1984 - grutas Lago Azul e São Miguel).

\begin{tabular}{|c|c|c|c|c|c|}
\hline Caverna & Medida & Tipo & Caverna & Medida & Tipo \\
\hline Gr. do Periquito & N72E/51SE & frat. & Gr. Lago Azul & N14E/50NW & frat. \\
\hline Gr. do Periquito & N83/81NW & frat. & Gr. Lago Azul & N10W/50SW & frat. \\
\hline Gr. do Periquito & N69E/86NW & frat. & Gr. Lago Azul & N2OW/3ONE & So \\
\hline Gr. do Periquito & N43W/42SW & frat. & Gr. Lago Azul & N15E/20SE & So \\
\hline Gr. do Periquito & N64W/24NE & So & Gr. Lago Azul & N84W/75NE & frat. \\
\hline Gr. Faz. América & N65E/30NW & So & Gr. Lago Azul & N78W/55SW & frat. \\
\hline Gr. Faz. América & N25E/vert. & frat. & Gr. Lago Azul & N5E/37NW & frat. \\
\hline Gr. Faz. América & N70E/80SE & frat. & Gr. Lago Azul & NS/30E & So \\
\hline Gr. Faz. América & N30W/25NE & So & Gr. Lago Azul & N24E/39SE & So \\
\hline Gr. Faz. América & N45W/40NE & So & Gr. Lago Azul & N40E/30SE & So \\
\hline Gr. Faz. América & N45W/37NE & So & Gr. Lago Azul & N20W/53SW & frat. \\
\hline Gr. Faz. America & N35W/65SW & frat. & Gr. Lago Azul & N85E/80SE & cliv. frat. \\
\hline Gr. Faz. América & N20W/vert. & frat. & Gr. Lago Azul & N10W/20NE & frat. \\
\hline Gr. Faz. América & N8OW/35NE & So & Gr. Lago Azul & N5W/56SW & frat. \\
\hline Gr. Faz. América & N235/75SE & frat. & Gr. Lago Azul & N55E/75NW & frat. \\
\hline Gr. Faz. América & N70W/2ONE & So & Gr. Lago Azul & N47W/26NE & So dobrado \\
\hline Gr. Faz. América & N10W/15NE & So & Gr. Lago Azul & N15W/42NE & So dobrado \\
\hline Gr. Lago Azul & N15W/20NE & So & Gr. Lago Azul & N10W/45NE & So dobrado \\
\hline Gr. Lago Azul & N15W/24NE & So & Gr. Lago Azul & N12W/65NE & So dobrado \\
\hline Gr. Lago Azul & N28W/25NE & So & Gr. Lago Azul & N10W/81NE & So dobrado \\
\hline Gr. Lago Azul & N07W/28NE & So & Gr. Lago Azul & N5W/85NE & So dobrado \\
\hline Gr. Lago Azul & N03E/26SE & So & Gr. Lago Azul & N8W/75NE & So dobrado \\
\hline Gr. Lago Azul & N2OW/24NE & So & Gr. Lago Azul & N7W/65NE & So dobrado \\
\hline Gr. Lago Azul & N20E/25SE & So & Gr. Lago Azul & NS/45E & So dobrado \\
\hline Gr. Lago Azul & NS/26E & So & Gr. Lago Azul & N10W/4ONE & So dobrado \\
\hline Gr. Lago Azul & N35E/37NW & So & Gr. Lago Azul & N9W/42NE & So dobrado \\
\hline Gr. Lago Azul & N15E/50SE & So & Gr. Lago Azul & NS/45E & So dobrado \\
\hline Gr. Lago Azul & N2OE/24SE & So & Gr. Lago Azul & NS/45E & So dobrado \\
\hline Gr. Lago Azul & N20E/28SE & So & Gr. Lago Azul & N30W/41SW & frat. \\
\hline Gr. Lago Azul & N2OE/15SE & So & Gr. Lago Azul & N72E/10NW & frat. \\
\hline Gr. Lago Azul & N10E/30NW & So & Gr. Lago Azul & N5W/20SW & frat. \\
\hline Gr. Lago Azul & N15E/20SE & So & Gr. Lago Azul & N4E/52NW & frat. \\
\hline Gr. Lago Azul & N80W/subvert. & frat. & Gr. Lago Azul & N2OW/5NE & frat. \\
\hline Gr. Lago Azul & NS/59W & frat. & Gr. Lago Azul & N30W/28SW & frat. \\
\hline Gr. Lago Azul & N21E/58NW & frat. & Gr. Lago Azul & N76E/82SE & cliv. frat. \\
\hline Gr. Lago Azul & EW/subvert. & frat. & Gr. São Miguel & N70W/70sW & cliv. frat. \\
\hline Gr. Lago Azul & N50W/42SW & frat. & Gr. São Miguel & N20W/37NE & So \\
\hline Gr. Lago Azul & N80W/84NE & frat. & Gr. São Miguel & N45W/3ONE & So \\
\hline Gr. Lago Azul & N60E/55NW & frat. & Gr. São Miguel & N25W/32NE & So \\
\hline Gr. Lago Azul & N40W/45SW & frat. & Gr. São Miguel & N4OW/41NE & So \\
\hline Gr. Lago Azul & N30E/60NW & frat. & Gr. São Miguel & N75E/78SE & frat. \\
\hline Gr. Lago Azul & EW/subvert. & frat. & Gr. São Miguel & N30E/35SE & frat. \\
\hline Gr. Lago Azul & N40W/45SW & frat. & Gr. São Miguel & N20E/85NW & frat. \\
\hline Gr. Lago Azul & N14E/50NW & frat. & Gr. São Miguel & N30W/35NE & So \\
\hline Gr. Lago Azul & N80W/subvert. & frat. & Gr. São Miguel & N50E/80NW & frat. \\
\hline
\end{tabular}




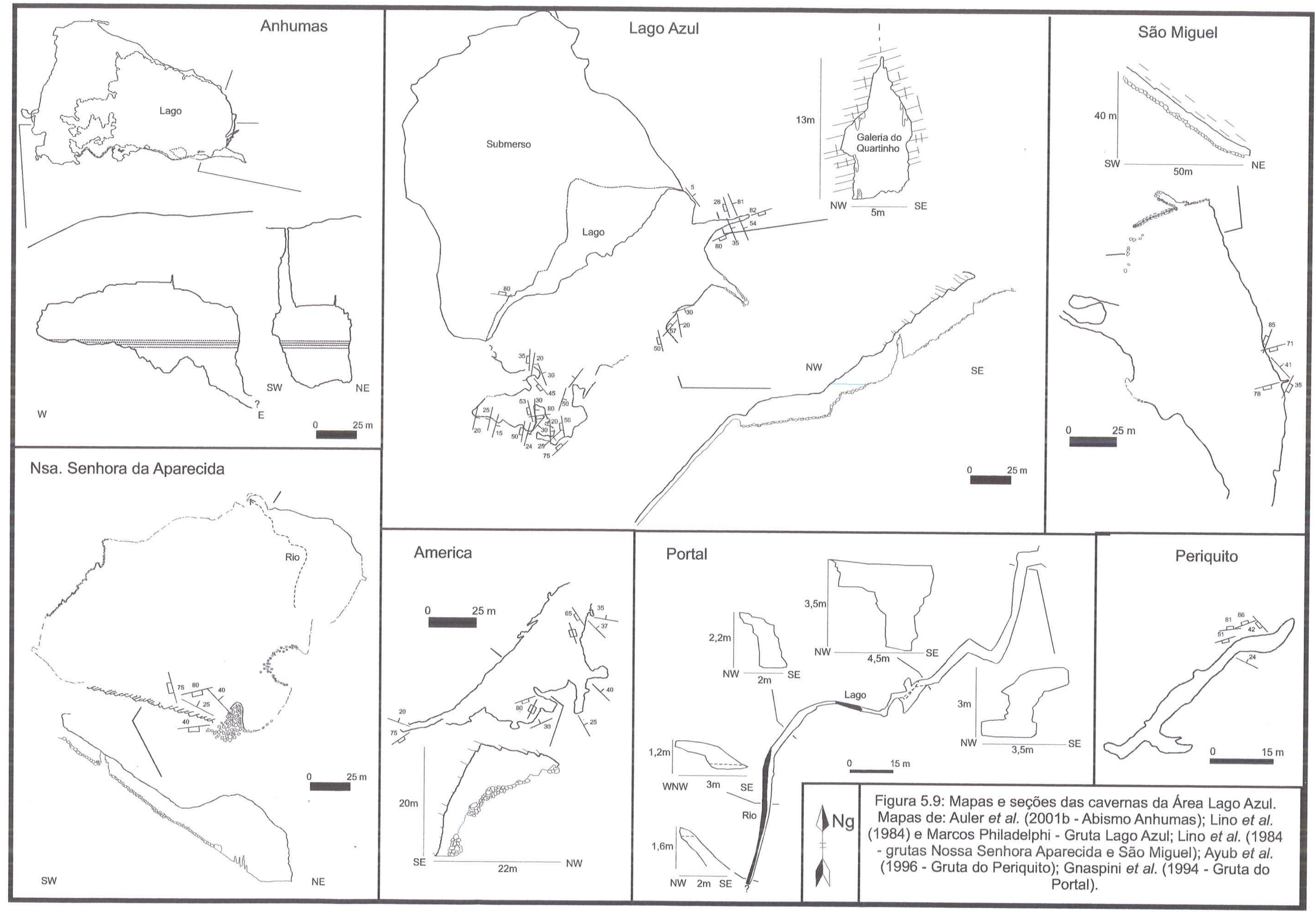



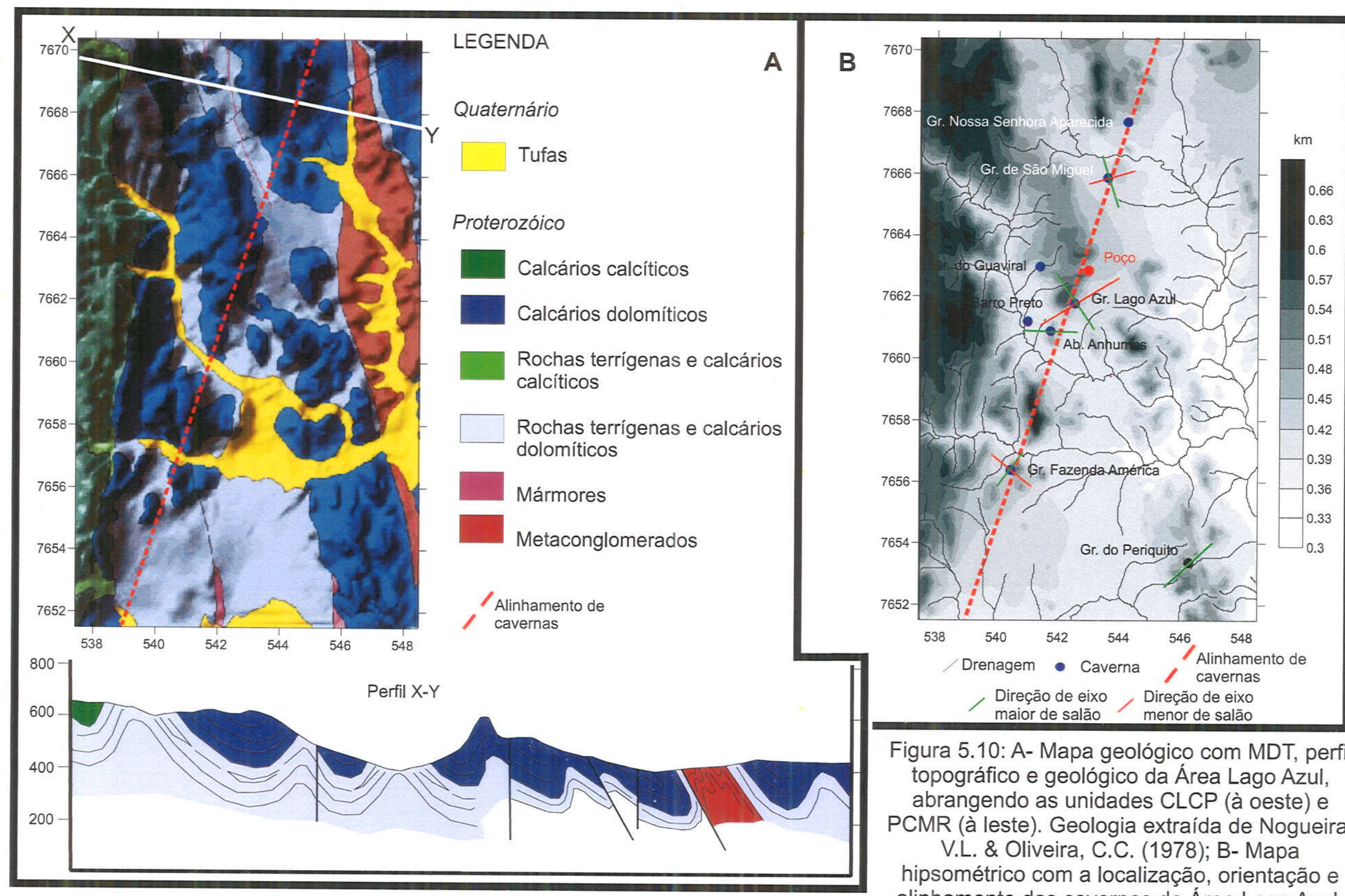

Figura 5.10: A- Mapa geológico com MDT, perfil topográfico e geológico da Área Lago Azul, abrangendo as unidades CLCP (à oeste) e PCMR (à leste). Geologia extraída de Nogueira, V.L. \& Oliveira, C.C. (1978); B- Mapa 은 hipsométrico com a localização, orientação e alinhamento das cavernas da Área Lago Azul. 


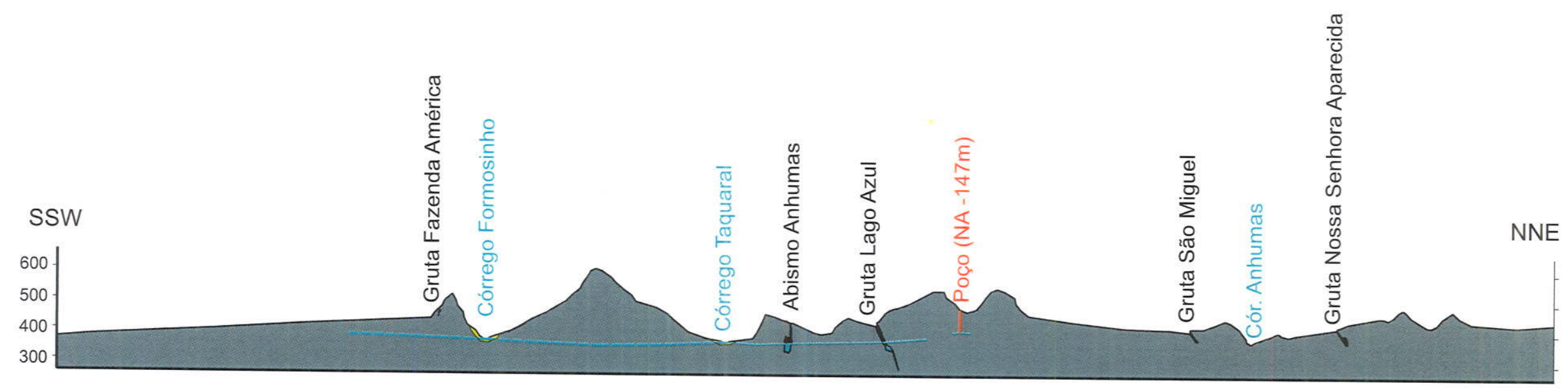

Figura 5.11: Perfil topográfico ao longo do alinhamento de cavernas indicado na Figura 5.10B.

Escala vertical exagerada. 


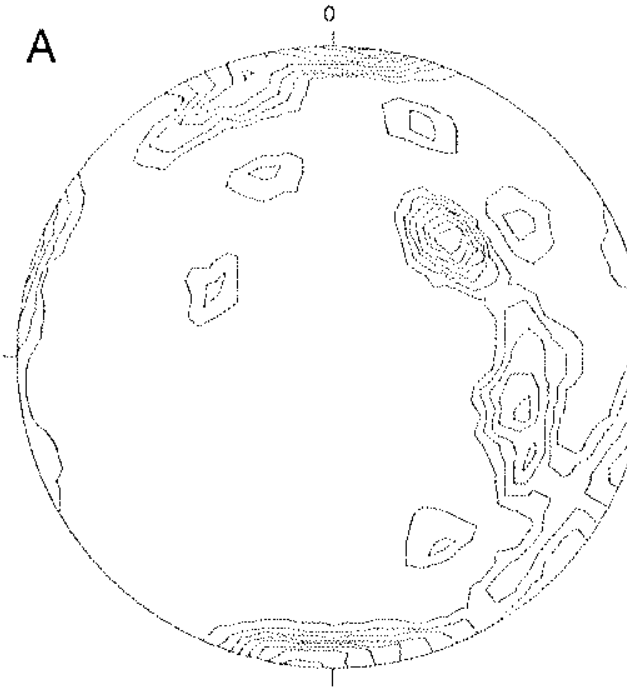

C

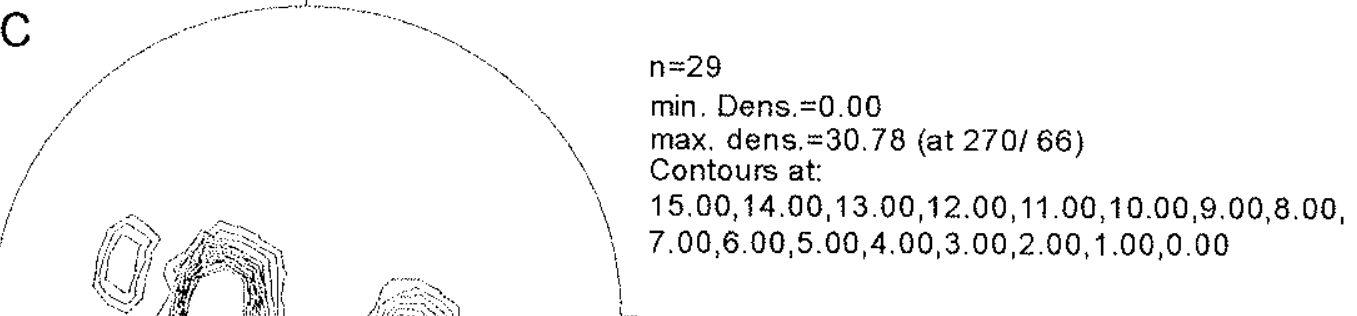

Figura 5.12: A e B- Estereograma e rosácea de fraturas das cavernas da Área Lago Azul; C-Densidade de pólos de acamamento das cavernas da Área Lago Azul. 

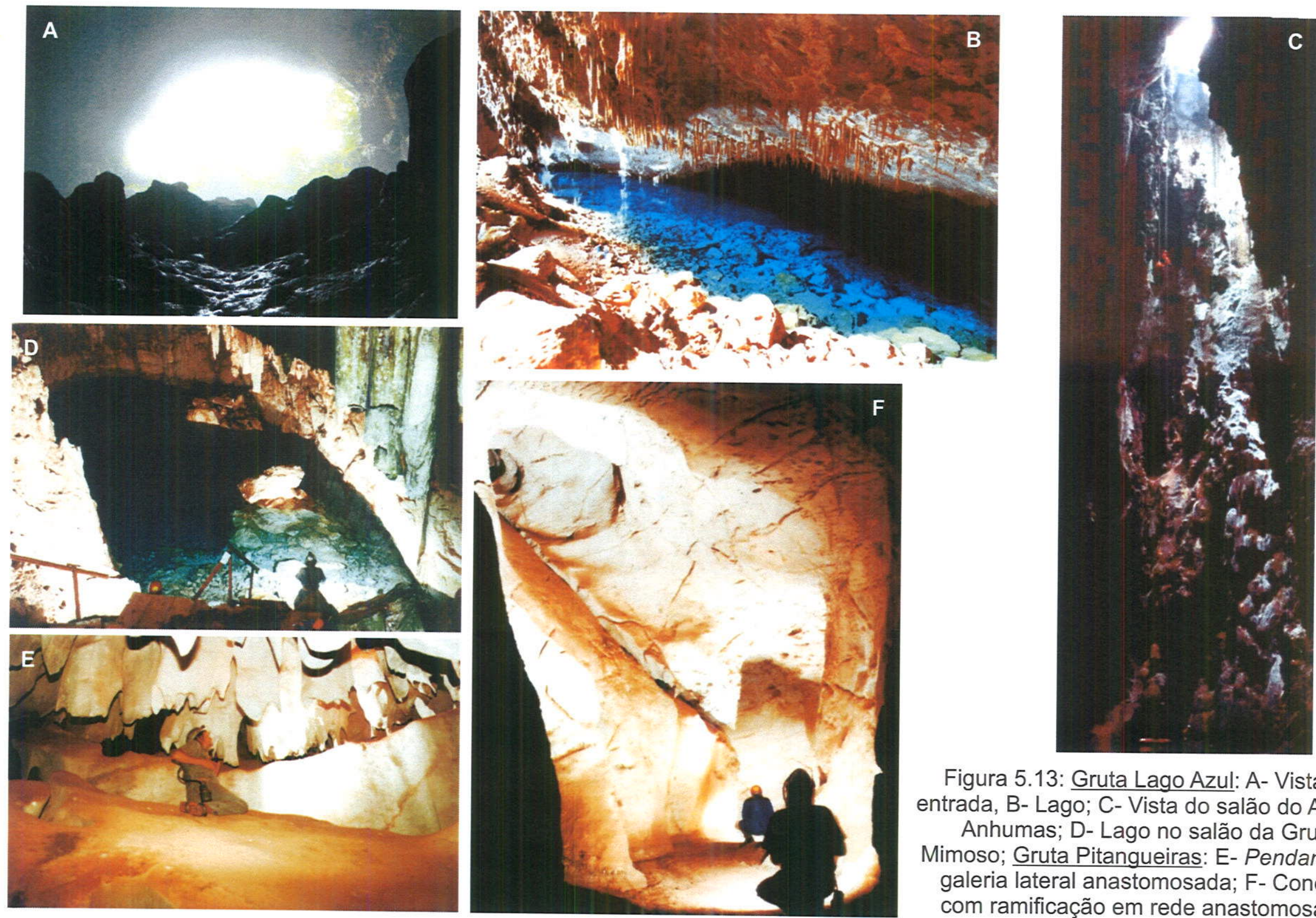

Figura 5.13: Gruta Lago Azul: A- Vista da entrada, B- Lago; C- Vista do salão do Abismo Anhumas; D- Lago no salão da Gruta Mimoso; Gruta Pitangueiras: E- Pendants em com ramificação em rede anastomosada. 
Espeleogênese

De maneira geral a origem destas cavernas pode estar relacionada a uma abertura freática inicial, seguido de abatimento em possivel ambiente vadoso e posterior subida do nivel d'água submergindo trechos das cavernas. Existem poucos elementos originais preservados dificultando o reconhecimento de feições que permitam observações precisas sobre a origem inicial destas cavernas. Mesmo assim algumas hipóteses serão aqui discutidas.

A primeira hipótese sobre a origem destas grutas foi formulada por Lino et al. (1984) baseando-se principalmente em observações de alguns condutos na Gruta Lago Azul, como a galeria do Quartinho, e parte dos salões dos Corais e da Cortina. A galeria do Quartinho não apresenta blocos abatidos, assim sendo um trecho preservado desta caverna. Segundo estes autores, na intersecção de fraturas com acamamento teriam sido formados os condutos inicias, de direção N7OE.

Uma segunda hipótese foi formulada por Kohler et al. (1998) que através da semelhança entre os perfis de condutos inclinados da Gruta Lago Azul e Nascente do Rio Formoso, propõe que estes salões teriam sido antigas nascentes (vauclusianas). Também coloca que estas nascentes teriam sido ativas numa época onde a escarpa leste, entre o Planalto da Bodoquena e a Depressão do Rio Miranda, estaria situada mais a leste, que progressivamente recuou para oeste. Os morros residuais seriam testemunhos desta escarpa situada hoje mais à oeste.

Avalia-se aqui que partes das duas hipóteses podem ser aceitas. Nas grutas Lago Azul, Nossa Senhora Aparecida, São Miguel e Fazenda América ocorrem testemunhos de condutos ascendentes em forma de fenda, ainda preservados. Estes condutos ascendentes estão presentes nas nascentes atuais como a do Rio Formoso e a CeitaCorê. Mas não se observa nenhuma evidência de que as fendas que ocorrem nos salões eram nascentes. As nascentes atuais ocorrem principalmente em calcários da Formação Cerradinho, na base da escarpa leste e os salôes encontram-se nos dolomitos. A Nascente do Rio Formoso se desenvolve numa direção E-W e NE-SW, sempre de oeste para leste e exibe um padrão anastomosado o que não é visto em nenhuma caverna nos dolomitos. Já os salões tem direções variadas (Tabela 5.9) mas formando entre si um alinhamento a N2OE (Figuras 5.10 e 5.11), que parece estar relacionado ao fraturamento regional (Figura 5.12).

Interpreta-se que estas cavernas de abatimento representam antigos condutos ascendentes de água de circulação profunda, que pertenciam a sistemas de condutos profundos e hoje são apenas formas reliquiares nos morros residuais. Estes sistemas de 
condutos não se interligavam necessariamente entre si as cavernas que vemos hoje e deveriam existir conexões que não são acessiveis ou que foram totalmente destruídas pelo abatimento.

Estes condutos se desenvolveram na interseç̧ão acamamento/fratura como descrito por Lino et al. (1984) na Gruta Lago Azul. As direções observadas nestes salões são as mesmas das fraturas medidas (Figura 5.12, Tabelas 5.9 e 5.10). Como as camadas estão na direção NS, os condutos seguiram as linhas de interseções desenvolvendo-se sobre os planos do acamamento.

$\mathrm{O}$ alinhamento na direção N2OE pode representar antigos sistemas de condutos ascendentes guiados por uma barreira impermeável, como uma camada de filitos intercalados nos carbonatos.

Algumas cavernas parecem ter comunicação em ambiente freático atualmente, como as grutas Lago Azul e Anhumas. Parâmetros hidroquímicos distintos levaram Auler et al. (2001b) a concluir que estas cavernas estariam separadas em ambiente freático, tratando-se de dois sistemas separados. Porém, mediçőes da variação do nível d'água mostram uma correlação entre a variação dos lagos das duas cavernas, sugerindo uma conexão inacessivel em ambiente freático (Figura 5.14). A diferença entre os parâmetros hidroquímicos das duas cavernas precisaria ser estudada, mas pode ser reflexo de variações litológicas ou na recarga do aqüífero. Esta possível conexão somente será comprovada ou não, através de testes com traçadores da água subterrânea.

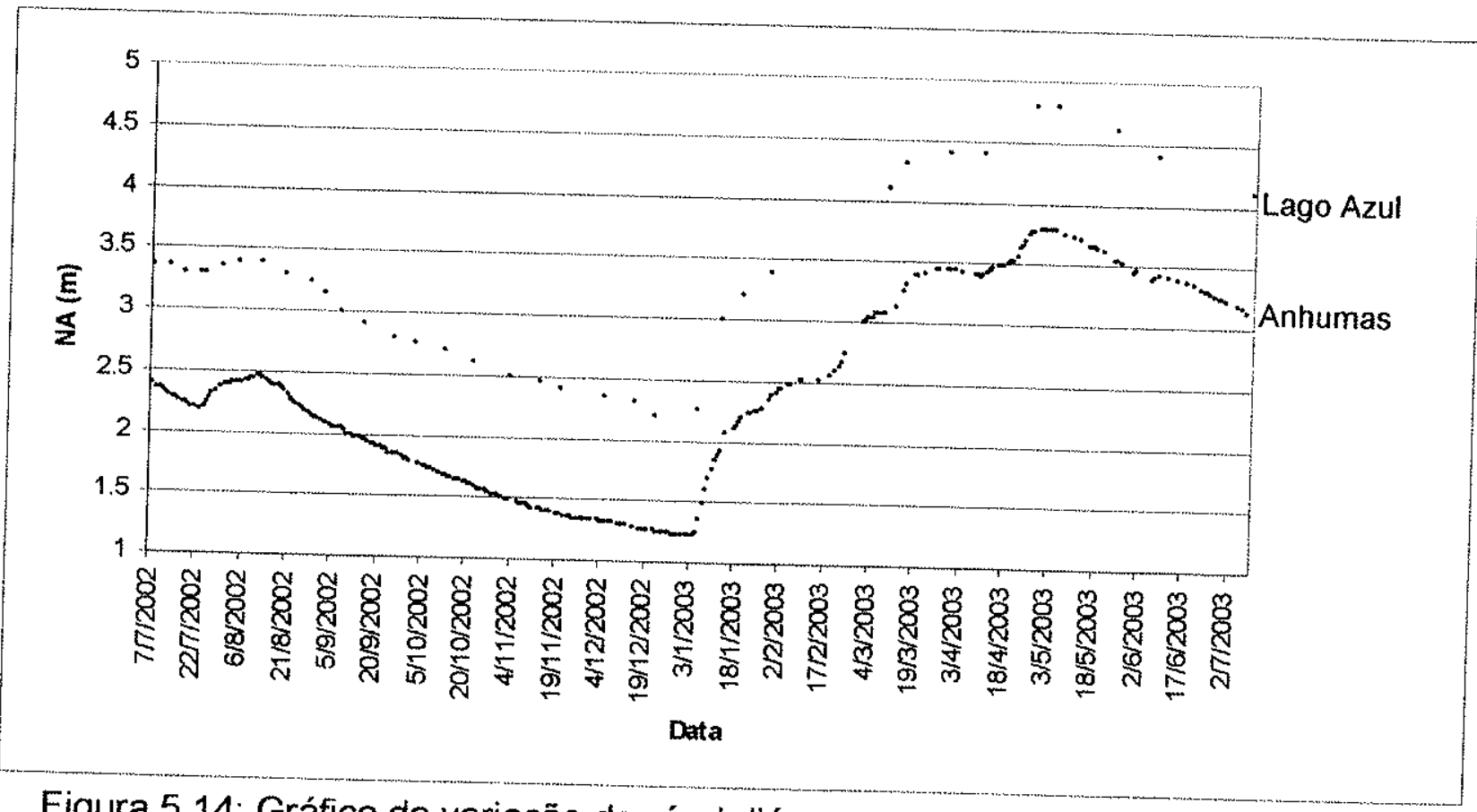

Figura 5.14: Gráfico da variação do nível d'água nas grutas Lago Azul e Anhumas. 
A existência de um aqüífero de condutos nos dolomitos é um fato comprovado por diversos poços perfurados por toda área e pela existência de diversas dolinas nas planicies da Unidade PCMR (Capítulo 4.3.4.1). Um destes poços situado na Fazenda Lago Azul foi utilizado por Auler et al. (2001b) para coleta de água e o alto teor de magnésio mostra tratar-se de um conduto nos dolomitos. Outro fato informação interessante deste poço é que está inserido no mesmo alinhamento N2OE descrito anteriormente, entre as grutas Lago Azul e São Miguel (Figuras 5.10 e 5.11). Neste poço a entrada de água, que deve corresponder à posição de um conduto freático, está a cerca de $147 \mathrm{~m}$ de profundidade (Auler et al., 2001b).

A individualização dos morros, como já proposto por Kohler et al. (1998), foi resultado da instalação de uma rede de drenagem (rebaixamento do nível d'água) que em parte tem suas nascentes na escarpa leste do planalto. $O$ aparecimento da escarpa teria possibilitado o surgimento das nascentes que posteriormente alimentaram a drenagem. Porém, como será discutido no Capítulo 6 , acredita-se que esta escarpa teria uma origem tectônica diferente do proposto por Kohler et al. (1998).

\subsubsection{2. Área Mimoso}

\section{Distribuição}

$\mathrm{Na}$ área da Gruta Mimoso as cavernas encontram-se com a morfologia original mais preservada do que na Área Lago Azul, apesar de também constituírem salöes de abatimento. Esta área situa-se a noroeste da cidade de Bonito, na direção à cidade de Bodoquena (Figura 5.1)

Foram investigadas as grutas Mimoso, João Arruda (salões de abatimento), Nascente do Ceita-Corê (nascente tipo vauclusiana) e a Gruta Pitangueiras (caverna em rede anastomosada).

\section{Morfologia e geologia das grutas Mimoso e João Arruda}

Estes salões de abatimento possuem forma em planta alongada na direção N58E na Gruta Mimoso e N65W na Gruta João Arruda. A Gruta Mimoso possui 125 m de eixo maior e a Gruta João Arruda $190 \mathrm{~m}$. Apresentam seções retangulares características de abatimento, modificadas na Gruta Mimoso pela presença de três chaminés

A Gruta Mimoso desenvolve-se em dolomitos recristalizados e o acamamento apresenta-se dobrado conforme mostra a Tabela 5.11 
Tabela 5.11: Medidas de direção de acamamento(So)e fraturas da Gruta Mimoso. 108

\begin{tabular}{|c|c|c|c|}
\hline Medida & Tipo & & Tipo \\
\hline N15E/65SE & frat. & $\begin{array}{c}\text { Medida } \\
\text { N75E/65SE }\end{array}$ & frat \\
\hline N35E/subvert. & frat. & N75E/subvert. & frat. \\
\hline $\begin{array}{c}\text { N40E/subvert. } \\
\text { N45E/80SE }\end{array}$ & $\begin{array}{l}\text { frat. } \\
\text { frat. }\end{array}$ & N80E/67SE & $\begin{array}{l}\text { trat. } \\
\text { frat. }\end{array}$ \\
\hline N50E/subvert. & frat. & $\mathrm{N} 80 \mathrm{E} / 55 \mathrm{SE}$ & So \\
\hline N52E/72SE & frat. & $\mathrm{N} 85 \mathrm{E} / 45 \mathrm{SE}$ & So \\
\hline $\begin{array}{l}\text { N55E/75SE } \\
\text { N55E/75SE }\end{array}$ & $\begin{array}{l}\text { frat. } \\
\text { frat. }\end{array}$ & N15W/3ONE & So \\
\hline
\end{tabular}

Morfologia e geologia da Gruta Ceita-Corê

Trata-se de uma caverna freática ativa (nascente), sendo um conduto em forma de fenda sub-vertical. Em planta tem forma elíptica, que é na verdade um seção da fenda
sub-vertical.

Em planta possui entre 10 a 15 metros de eixo menor e maior e alcança profundidades de mais de $120 \mathrm{~m}$. Desta forma caracteriza um conduto ascendente quase vertical.

Não são conhecidos espeleotemas. 


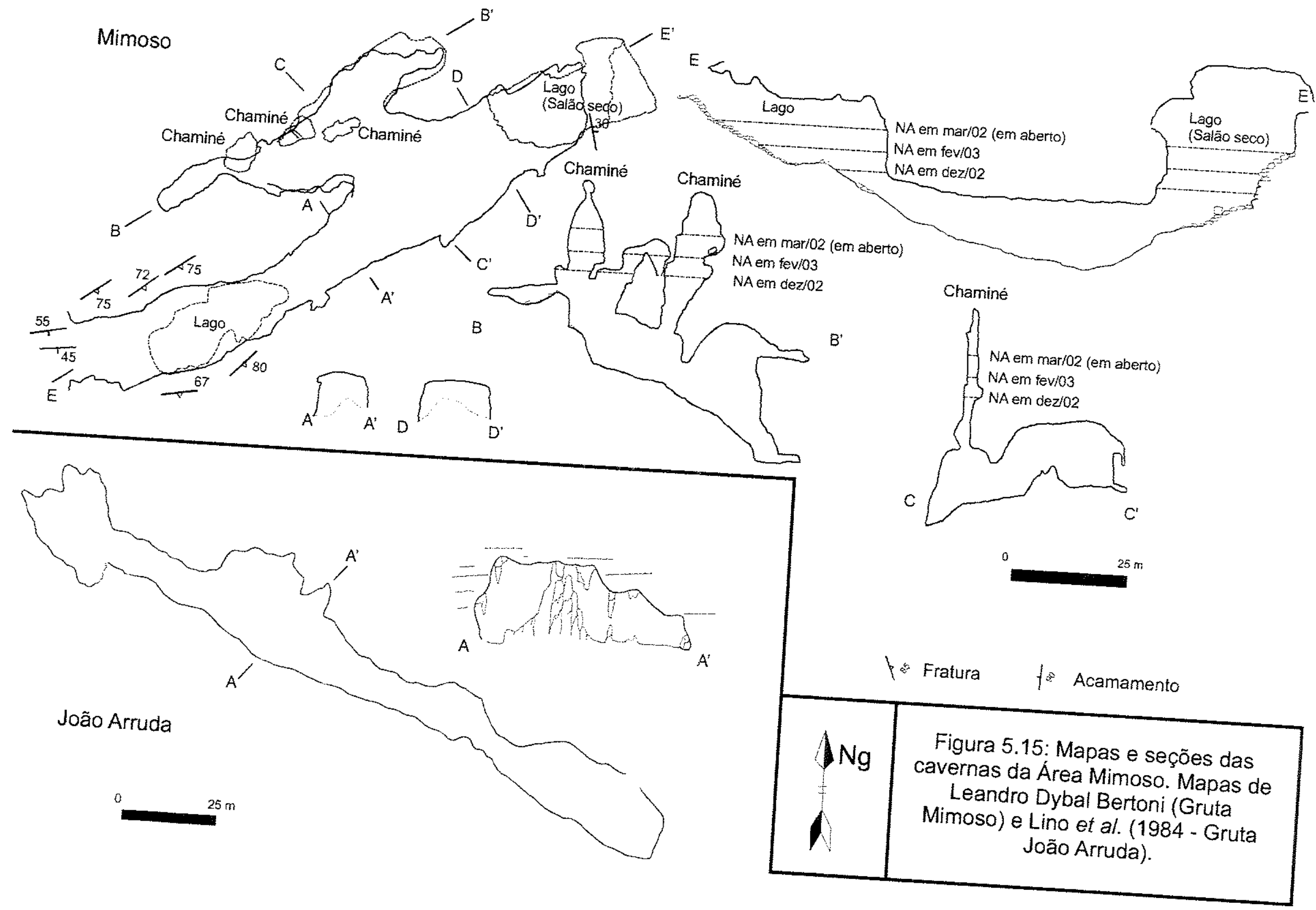



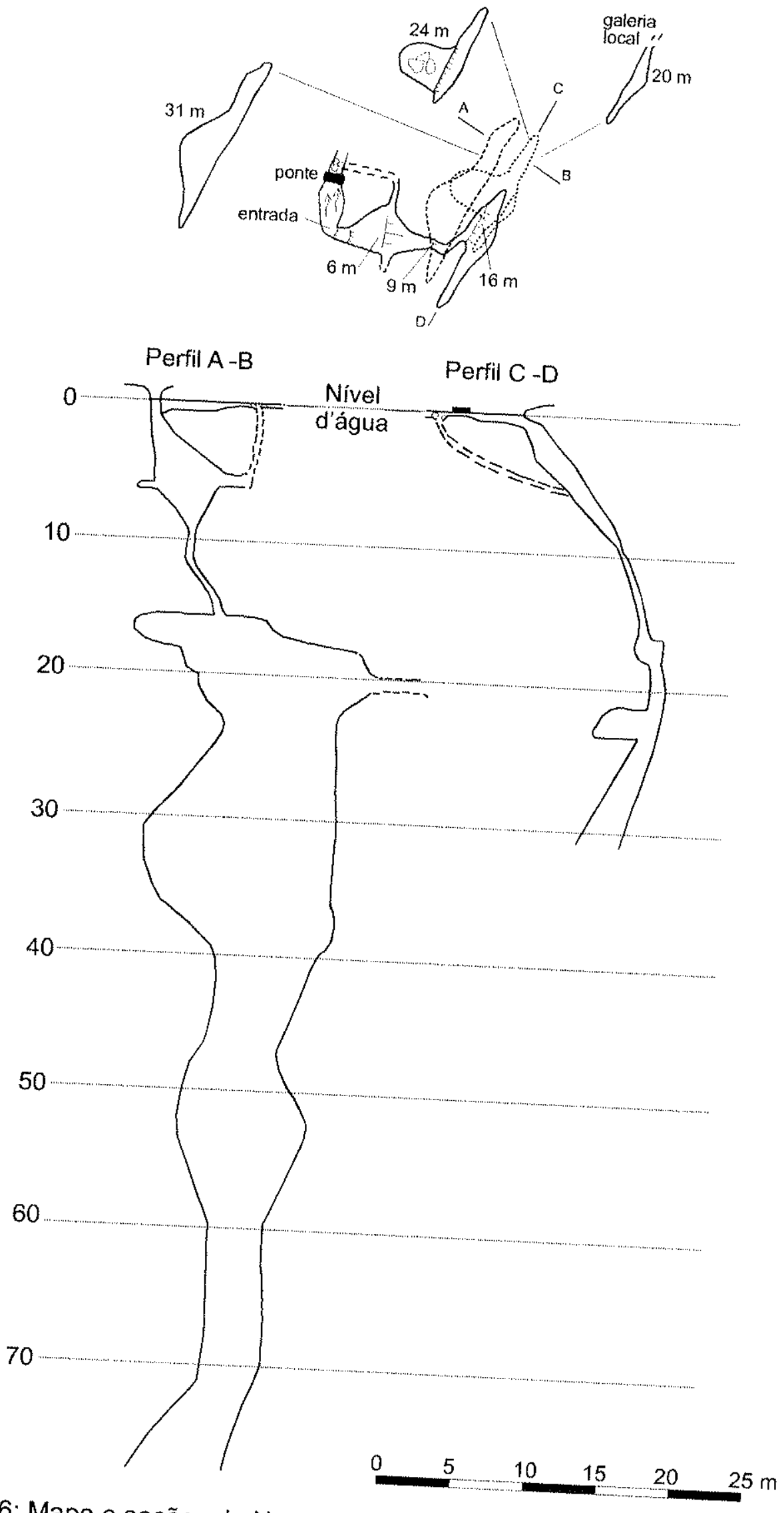
Figura 5.16: Mapa e seções da Nascente da Ceita-Curê (mapa de Leandro
Dybal Bertoni). 


\section{Morfologia e geologia da Gruta Pitangueiras}

A Gruta Pitangueiras é a segunda maior caverna do estado e exemplo mais completo de uma caverna da Serra da Bodoquena com morfologia original preservada Encontra-se em um morro testemunho de calcário na Unidade PCMR, na área dos dolomitos.

Desenvolve-se em calcário estratificada intercalado com uma brecha carbonática, com acamamento de direção $\mathrm{E}-\mathrm{W} / 25 \mathrm{~N}$ como uma rede de condutos interligados com padrão em rede ora anastomosada ora labirintica (Figura 5.17). Estes condutos estão orientados segundo as direções gerais NNW e EW (Figura 5.18). Possui $1300 \mathrm{~m}$ de desenvolvimento e $20 \mathrm{~m}$ de desnivel.

A rede anastomosada está presente nos setores norte e central da caverna. Analisando apenas um conduto isolado vemos que em planta apresenta-se como um conduto retilíneo simples, mas quando visto em seção percebe-se que são condutos desenvolvidos em planos inclinados onde vários condutos menores estăo presentes, o que não se pode representar em planta. Pelo menos três destes planos inclinados em rede anastomosada ocorrem na caverna: um a oeste, um central e outro a leste (Figura 5.17, perfil FF-FF'). Estas redes anastomosadas estão em planos inclinados de direção entre N12W a N30W com mergulhos para oeste. Nestes casos fraturas condicionam estas redes. Outras redes se desenvolvem localmente na direção $\mathrm{E}-\mathrm{W}$, seguindo fraturas ou acamamento (Figuras 5.17, perfil W-W' e 5.13F). Os condutos secundários dentro das redes anastomosadas apresentam-se geralmente em forma de fendas verticais (Figuras 5.17, perfil W-W'). A rede anastomosada trata-se de fendas verticais entrelaçadas, e conectadas pela base.

No setor sul a caverna desenvolve-se com uma forma de rede labiríntica em planta, e em seção como fendas verticais. Estas fendas apresentam morfologia de fendas e tubos freáticos na parte superior (Figura 5.17, perfil Z-Z'). Esta rede labiríntica tem duas direções preferências quase ortogonais, uma a N11W e outra a N87W.

Canyons vadosos ocorrem na base de algumas seções por toda a caverna, e possuem forma retilínea acompanhando fraturas (Figura 5.17, perfis F-F', W-W e Z-Z') 


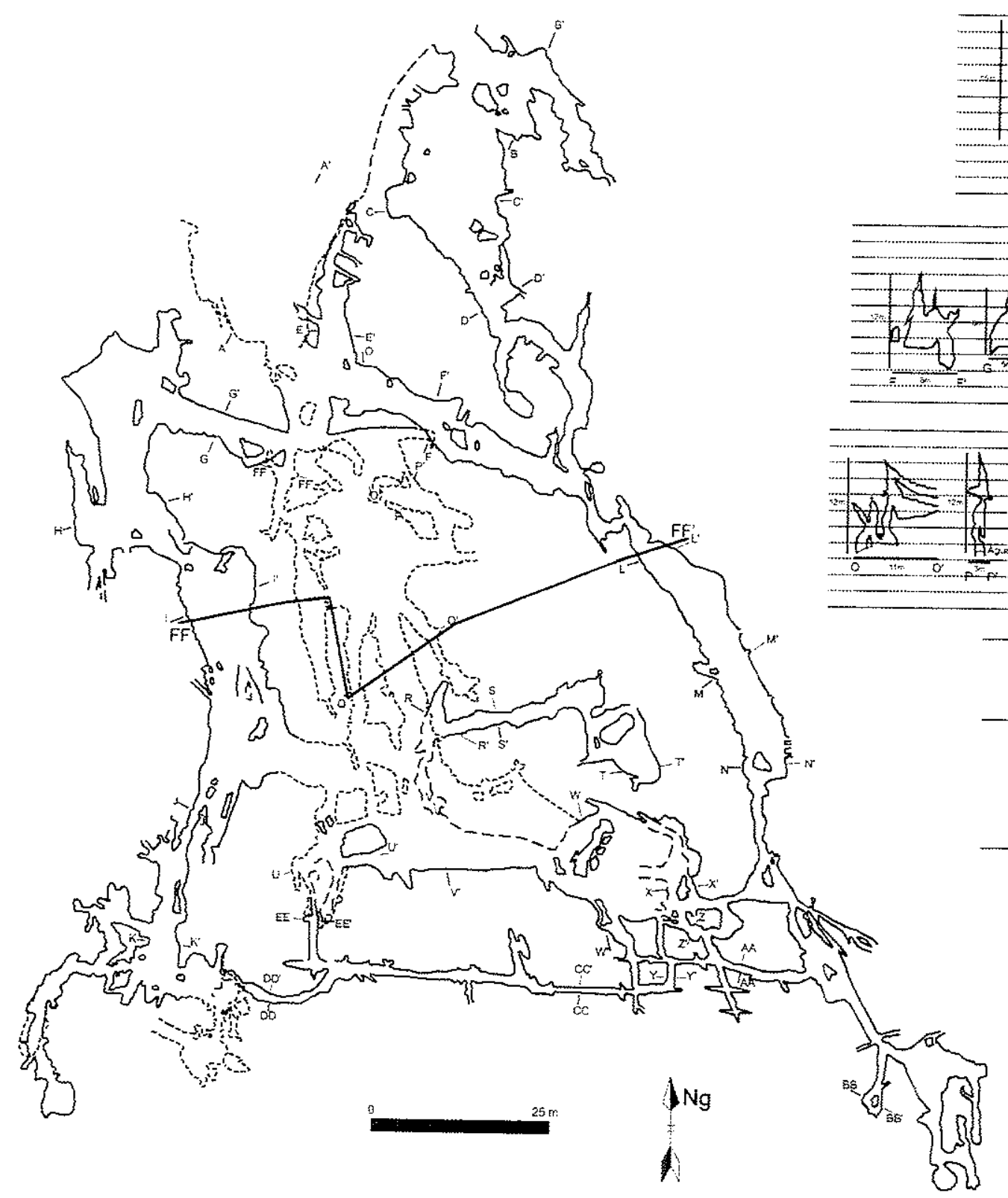

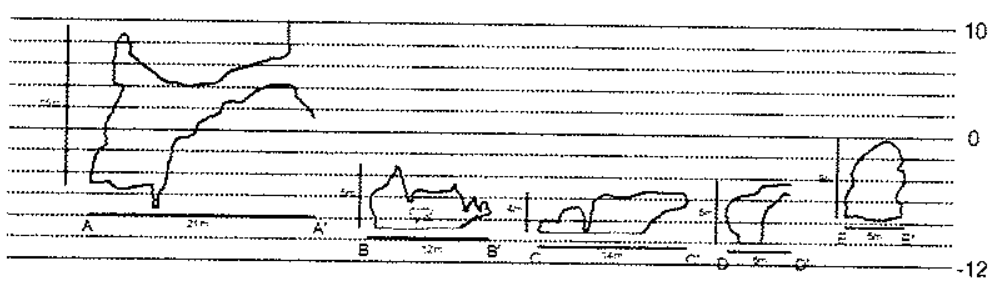

-12
-10
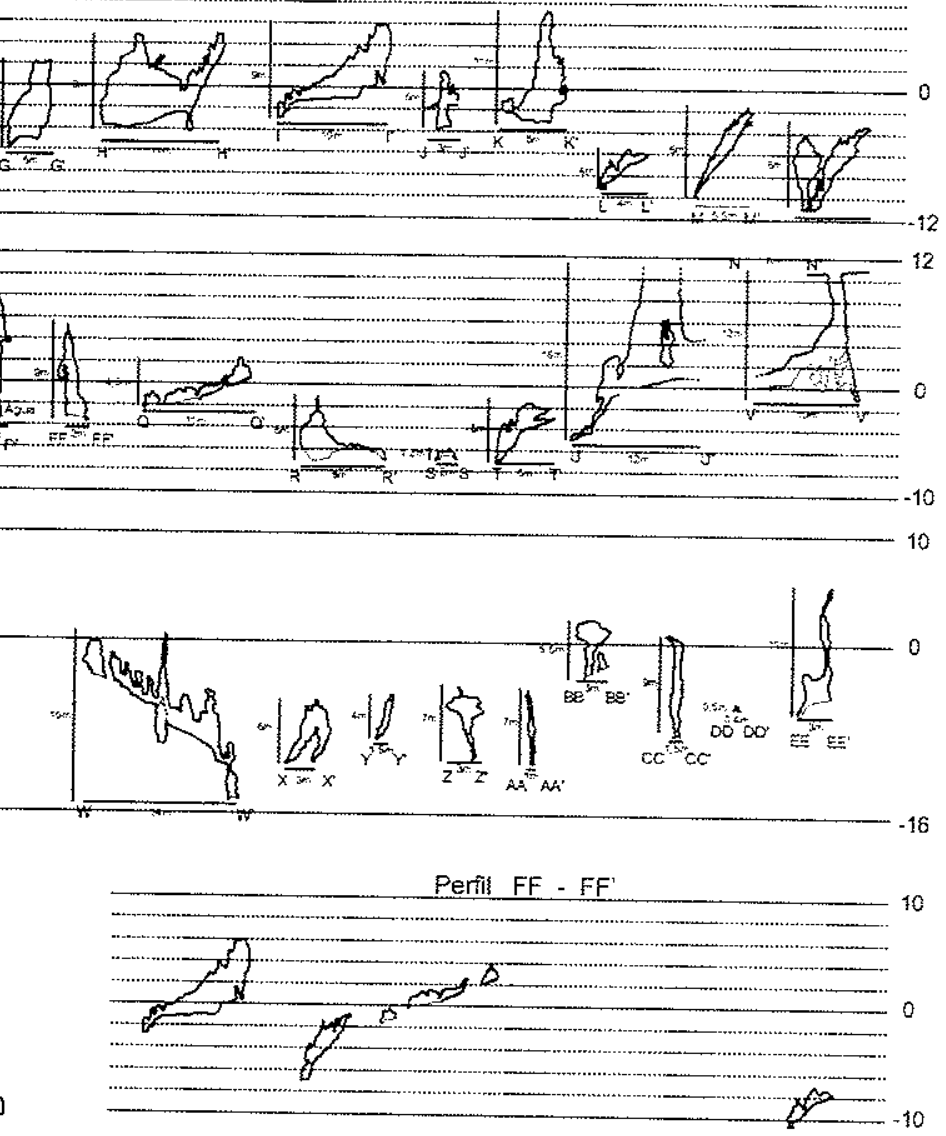

Figura 5.17: Mapas e seções da Gruta

Pitangueiras. Mapa de Leandro Dybal Bertoni e Alexandre de Oliveira Lobo. 

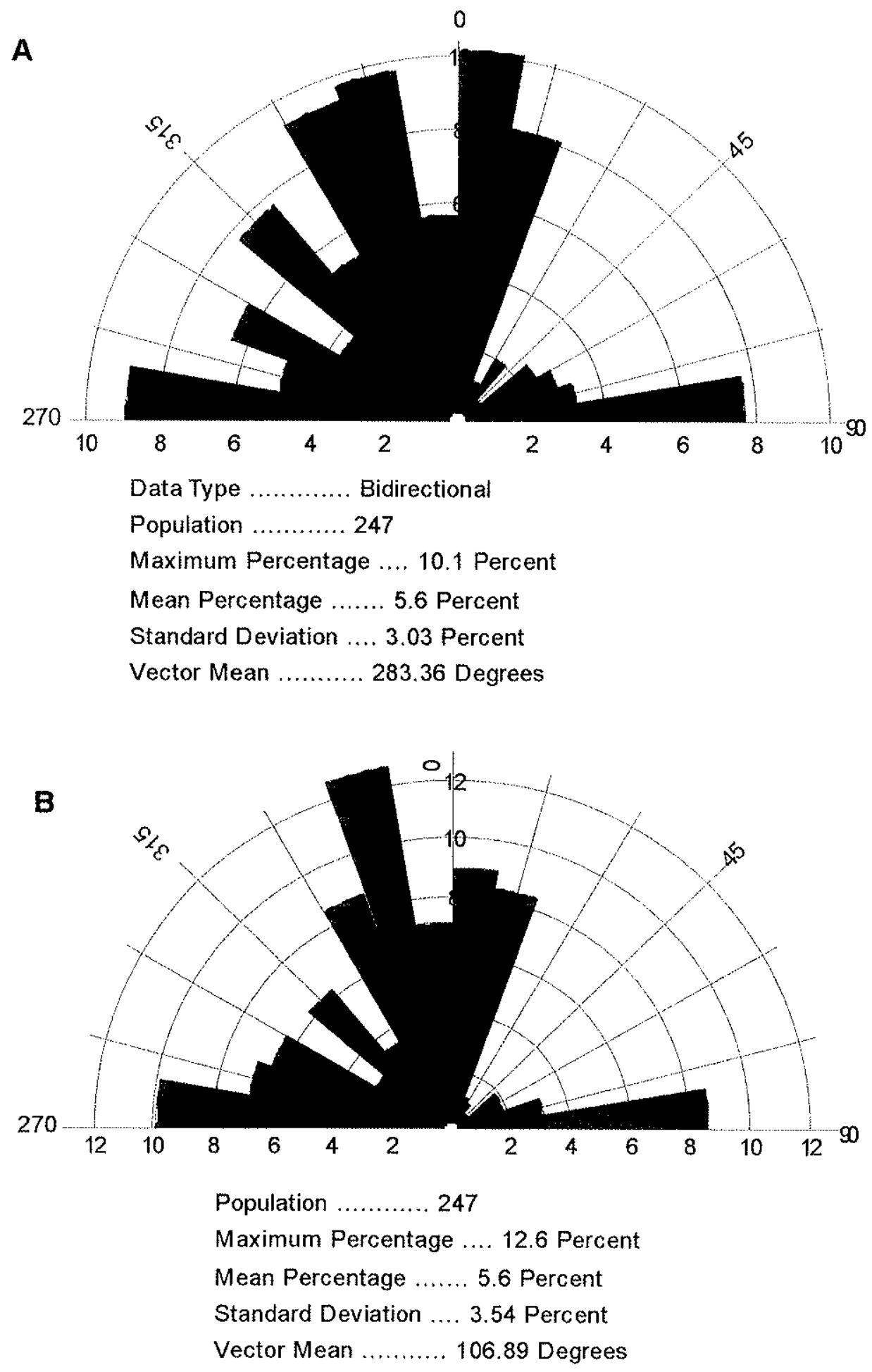

Figura 5.18: Rosáceas de freqüência (A) e comprimento (B) de condutos da Gruta Pitangueiras. 
Espeleogênese das grutas Mimoso e João Arruda

Da mesma forma que nos salões da Área Lago Azul, interpreta-se a origem das grutas Mimoso e João Arruda por abertura freática inicial seguido de abatimento. Mas diferentemente dos salões da Área Lago Azul estas grutas apresentam parte preservada e o conduto original aqui parece ter sido um conduto simples.

No caso da Gruta Mimoso após esta abertura inicial freática houve o abatimento e posterior alagamento. Já na Gruta João Arruda houve assoreamento.

\section{Espeleogênese da Gruta Ceita-Corê}

Esta caverna trata-se do melhor exemplo de uma nascente do tipo vauclusiana onde provavelmente alguma barreira impermeável condiciona a subida de água de forma abrupta, quase na vertical.

A forma elíptica em planta é uma seção desta fenda ascendente e representa uma morfologia freática.

\section{Espeleogênese da Gruta Pitangueiras}

A iniciação nesta caverna se deu em planos de anastomose e também em fendas freáticas verticais. O fluxo estava condicionado preferencialmente nas fraturas e as direções dos condutos possuem as mesmas direções destes sistemas de fraturas. A ampliação dos condutos se deu lateralmente acompanhando planos de acamamento e fraturas e verticalmente, acompanhando fraturas, em ambiente de fluxo lento. Diferentemente das outras cavernas em rede anastomosada, os condutos secundários possuem seção semi-circular e também em fendas.

Porém esta anastomose não atingiu toda caverna, pois trechos em rede labirínticas são presentes no setor sul.

Posteriormente em ambiente vadoso há um entalhamento de canyons retilíneos na base de alguns condutos.

Por fim, abatimentos e invasões vadosas do epicarste modificaram a forma original. Diversas clarabóias ocorrem na caverna, evidenciando estes processos. 


\subsubsection{3. Área Bodoquena}

\section{Distribuição}

Neste setor diversas cavernas são conhecidas, mas poucas são mapeadas. Situase nas proximidade da cidade de Bodoquena, na região do Assentamento Campina. Investigou-se as cavernas Cinco de Ouros, Manoel Cardoso e Benedita.

Estas cavernas situam-se na Unidade PCMR, mas estão próximas a planície aluvial do baixo Rio Salobra (Unidade CPA). Distam cerca de $250 \mathrm{~m}$ entre si, formando um alinhamento a N23E.

\section{Morfologia e geologia da Gruta Cinco de Ouros}

A Gruta Cinco de Ouros desenvolve-se em calcário estratificada sub-horizontal, de direções N20W/05NE e N30E/05NW. Possui $225 \mathrm{~m}$ de desenvolvimento e $25 \mathrm{~m}$ de desnivel. Sua entrada localiza-se em uma planície e o acesso a caverna é feito através dela.

Trata-se de um conduto meandrante ramificado em planta (Figura 5.19) de direção geral N-S. Em seçäo apresenta seções de retangulares a circulares (Figuras $5.19 \mathrm{e}$ 5.20A). Um lago ocorre nos dois extremos da caverna.

Porém em todas as seções não se observa a base devido ao preenchimento sedimentar. Este preenchimento é composto de areias na maior parte da caverna e de argilas próximo à entrada e possui espessura métrica (Figura 5.19, perfil A-A').

Destaca-se a presença de vulcões desenvolvidos sobre o preenchimento arenoso em uma grande represa de travertino (Figuras 5.20A e B). Estes vulcões estão alinhados segundo direções de gotejamentos em fraturas no teto (Figuras 5.20A e B).

\section{Morfologia e geologia da Gruta Benedita}

Desenvolve-se em calcário estratificado de direção N15W/4ONE. Possui $161 \mathrm{~m}$ de desenvolvimento e $27 \mathrm{~m}$ de desnivel. Sua entrada é uma dolina de abatimento (Figuras 5.20E e 5.21).

Trata-se de um conduto meandrante ramificado em planta (Figura 5.21) de direção geral N-S. Apresenta-se parcialmente preenchida por sedimentos argilosos especialmente no setor norte da caverna. O setor sul da caverna seção apresenta seção em canyons meandrantes (Figura 5.21, perfis A-B, C-D, E-F e G-H), e o setor norte morfologia de cúpulas (Figura 5.21, perfis K-L, M-N e O-P). Pelo menos 5 cúpulas foram observadas (Figura 5.21) com forma arredondada (Figura 5.20E). As cúpulas estão interligadas por passagens na sua parte inferior formando "pontes de pedra" (Figura 
5.21, perfil O-P). Estas cúpulas juntamente com condutos de seção eliptica (Figuras $5.20 D$ ) estão na parte superior dos canyons, no topo do depósito sedimentar. No setor norte estas feições são acessíveis devido ao preenchimento sedimentar.

Nas cúpulas observou-se a presença de marcas do nivel d'água (Figura 5.21, perfis M-N e O-P) e abaixo destas marcas depósitos de crostas subaquáticas (Figura $5.20 \mathrm{~F})$.

\section{Morfologia e geologia da Gruta Manoel Cardoso}

A Gruta Benedita desenvolve-se no contato entre uma brecha carbonática (topo) e um calcário estratificado (base), com acamamento de direções entre N2OE/10SE e N55E/20SE. Estas rochas carbonáticas encontram-se abaixo de filitos, observados na entrada da caverna (Figura 5.22, perfil K-L). Possui $100 \mathrm{~m}$ de desenvolvimento e $11 \mathrm{~m}$ de desnivel.

É composta de uma galeria principal por onde há um leito de rio intermitente, e de ramificação em galerias retilíneas (Figura 5.22). No final da caverna há um lago. Tratase de um sumidouro ativo nas épocas chuvosas. Em seção apresenta morfologia elíptica a retangular (Figura 5.22).

\section{Espeleogênese}

Neste setor as cavernas Cinco de Ouros e Benedita não exibem evidências da fase de iniciação, ou seja, estão modificadas por processos posteriores. Nestas grutas estes processos são relacionados a paragênese devido ao preenchimento sedimentar, além de abatimento. Condutos elípticos presentes no teto são relacionados ao crescimento paragenético devido ao preenchimento sedimentar. Da mesma forma as cúpulas estão relacionadas ao preenchimento sedimentar, mas a uma fase final da sedimentação onde o fluxo tornou-se lento e não ouve mais formação de condutos paragenéticos. Nesta fase as cúpulas podem ter sido desenvolvidas acima do nivel d'água através de corrosão por condensação, o que também modificou as formas de ampliação paragenética. Este fluxo lento de água é evidenciado pelas crostas subaquáticas que ocorrem associadas a cúpulas na Gruta Benedita.

Pela proximidade entre as grutas Cinco de Ouros e Benedita supõe-se que elas pertenciam a um mesmo sistema de condutos que foram separados por abatimento $\mathrm{e}$ assoreamento.

Na Gruta Manoel Cardoso condutos elípticos são relacionados a uma fase freática, posteriormente superposta por uma fase vadosa, que imprime um contorno retangular 
aos condutos. Nesta gruta a descontinuidade que deu origem aos condutos na iniciação foi o contato entre brechas carbonáticas e calcários. A situação da Gruta Manoel Cardoso em relação às outras cavernas pode ser interpretada com um sumidouro que injeta água ao sistema de condutos das grutas Cinco de Ouros e Benedita. 


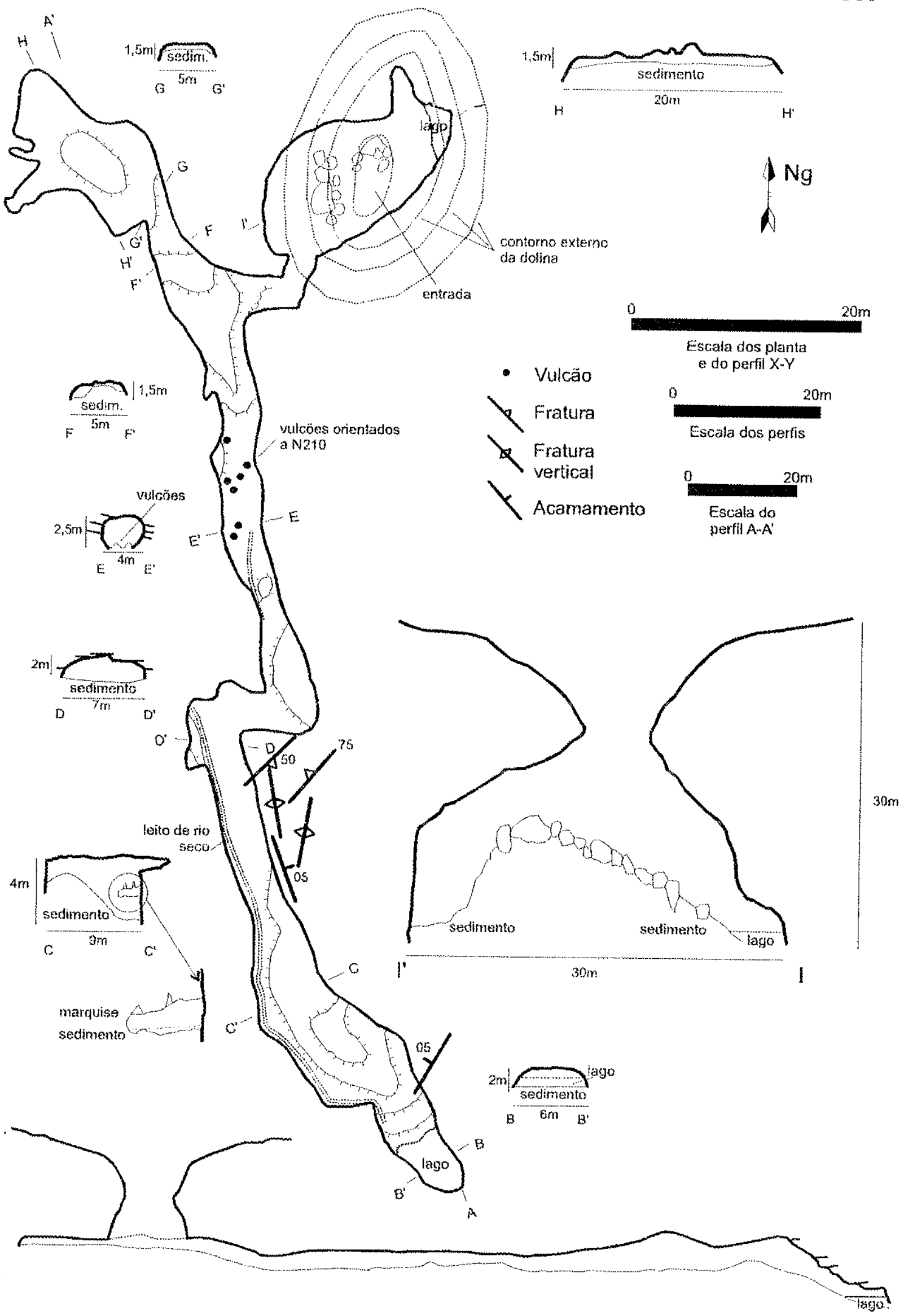

Figura 5.19: Mapa e seções da Gruta Cinco de Ouros. 

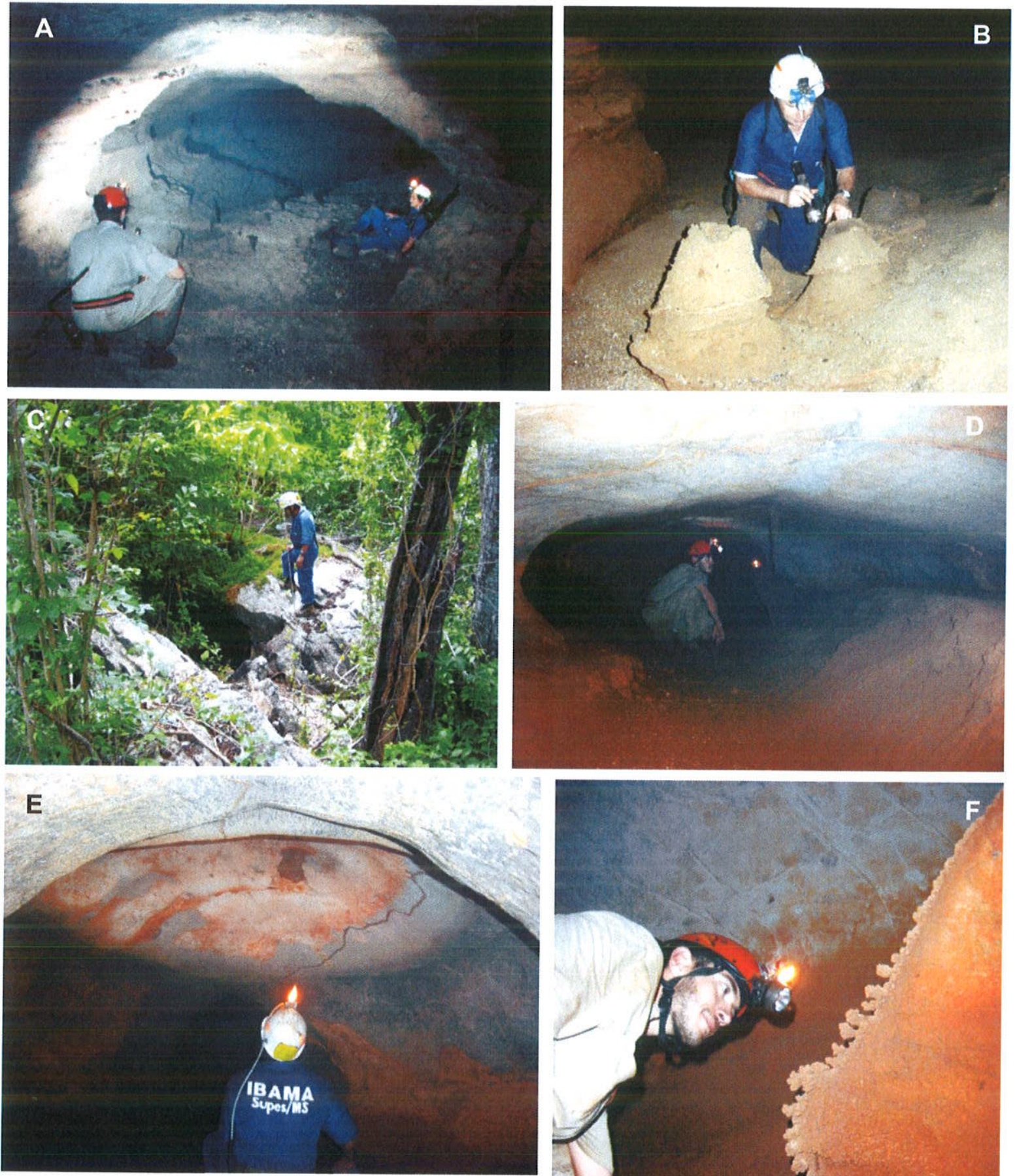

Figura 5.20: Cavernas da Área Bodoquena. Gruta Cinco de Ouros: A- Conduto com seção circular com sedimentos na base e vulcões sobre os sedimentos; B- Vulcões alinhados. Gruta Benedita: C- Entrada em dolina; D- Conduto elíptico paragenético,

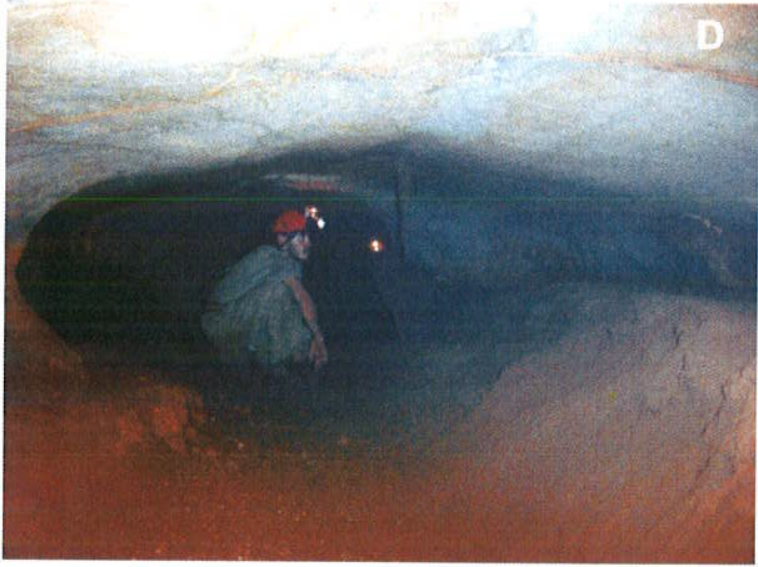
com sedimentos na base; E- Cúpula

exibindo marca do nível d'água; F- Base de cúpula com depósitos de crosta subaquática.

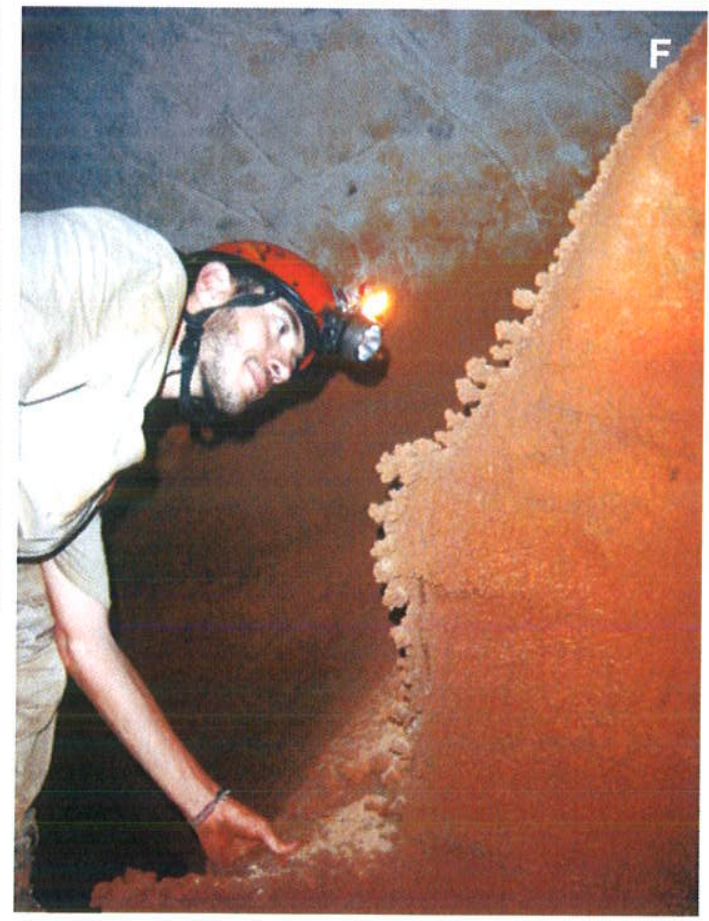




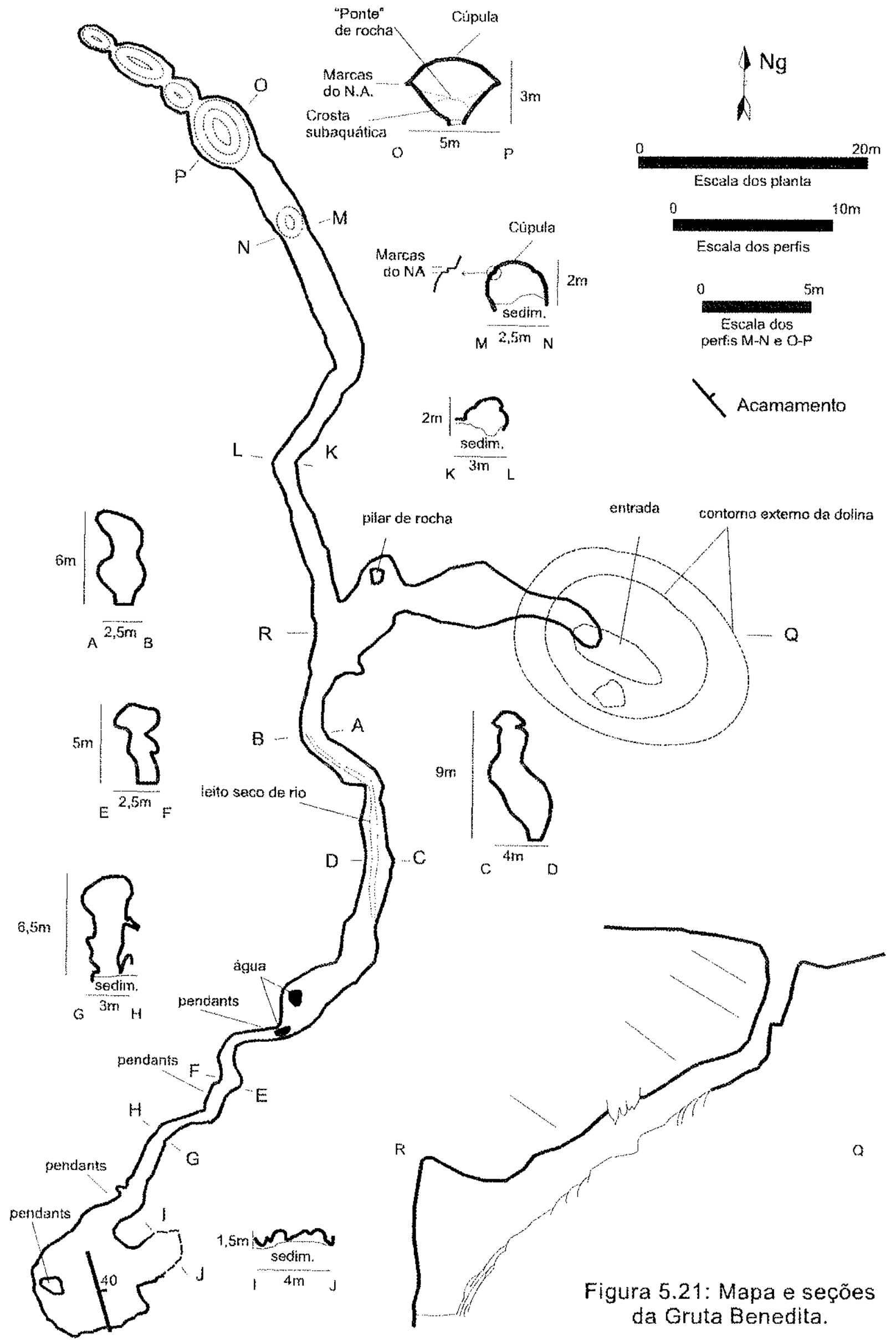




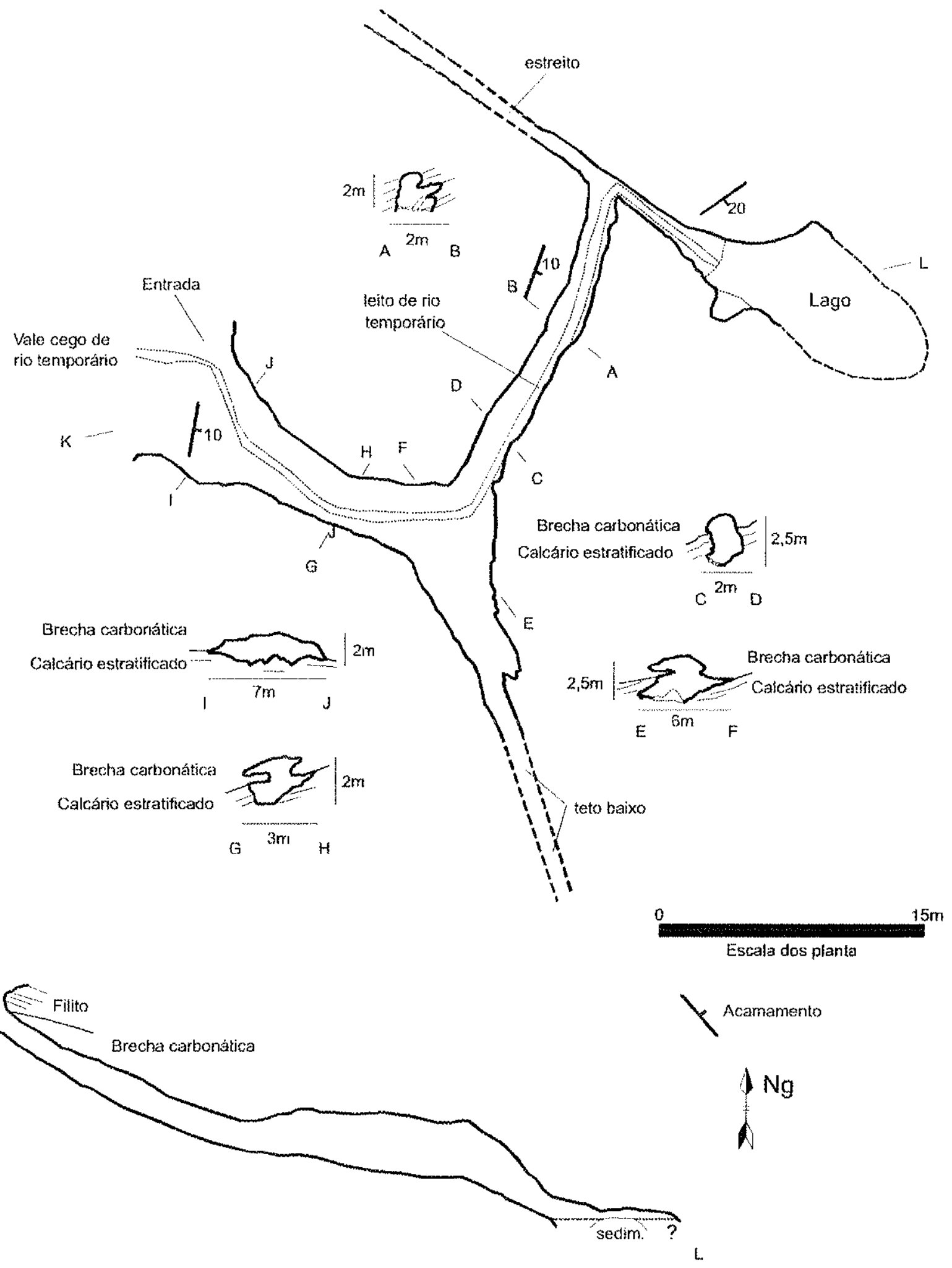

Figura 5.22: Mapa e seções da Gruta Manoel Cardoso. 


\subsubsection{4. Área das Nascentes}

\section{Distribuição}

Esta área situa-se nas bordas da escarpa leste do Planalto da Bodoquena, nas planícies da Unidade PCMR. Duas nascentes encontram-se próximas à escarpa, a Nascente do Rio Formoso e o Buraco das Abelhas, e outras duas mais distantes a sul da escarpa, o Buraco do Fóssil (ou do Japonês) e o Buraco do Sapo. Apresentam fluxo de água para leste. O Buraco das Abelhas é a maior caverna conhecida do estado. Apesar de não estar mapeada sabe-se que foram realizados mergulhos até $1900 \mathrm{~m}$ de extensão.

Estas cavernas são nascentes desenvolvidas em calcários da Formação Cerradinho (segundo mapeamento de Nogueira \& Oliveira, 1978), que estão estratigraficamente intercalados aos calcários do planalto (superiores) e dos dolomitos das planícies (inferiores). As nascentes do Formoso e do Fóssil são constituidas de calcário oolítico que aparentemente formam uma mesma camada, apesar de estarem distantes.

Será analisada apenas a Nascente do Rio Formoso, pois é a única que possui um mapa detalhado, mesmo preliminar (Figura 5.23). Os croquis das outras três grutas são apresentados na Figura 5.24 para comparação.

Ocorrências de fósseis são conhecidas nas nascentes do Formoso (Leandro Salles, informação verbal) e do Fóssil (Salles et al., 2003). Não ocorrem espeleotemas nestas cavernas.

\section{Morfologia e geologia da Nascente do Rio Formoso}

A Nascente do Rio Formoso desenvolve-se em calcários da Formação Cerradinho com atitudes de acamamento entre NO5E e N30E com mergulhos entre 35 e $40^{\circ}$ para SE, medidos nos pontos 150 e 151, pois na entrada da caverna o acamamento não é visivel. Possui duas saídas de água, conhecidas como Formoso, a leste, e Formosinho, a oeste que se conectam no interior da caverna. Desenvolve-se na direção geral SWNE. Com cerca de $800 \mathrm{~m}$ de desenvolvimento (parcial) e 80 metros de profundidade (desnivel), é composta por três condutos, um a leste, um central e outro a oeste, que se conectam no fundo da caverna. São condutos meandrantes sinuosos com ramificações em condutos menores não explorados. O conduto leste é a parte mais rasa da caverna, com profundidades entre 5 e $17 \mathrm{~m}$. O conduto central está entre 13 e $30 \mathrm{~m}$ de profundidade. O conduto oeste, conhecido como Formosinho é o mais profundo com profundidades entre 20 e $56 \mathrm{~m}$. Os condutos leste e central se conectam a $38 \mathrm{~m}$ de 
profundidade, tornando-se um conduto único que por sua vez, se conecta ao conduto oeste a profundidade de $56 \mathrm{~m}$. A partir deste ponto forma-se um único conduto que atinge a profundidade de $80 \mathrm{~m}$, apresentando continuidade. No conduto oeste (Formosinho) são conhecidas ocorrências de fósseis (Leandro Salles, informação verbal) de mamíferos pleistocênicos principalmente mastodontes. Neste ponto do conduto oeste são conhecidas algumas chaminés (Ismael Escote, informação verbal) que podem estar conectadas com a superfície que podem ser o ponto de entrada dos fósseis neste conduto. $\mathrm{Na}$ base destas chaminés, além de fósseis, ocorrem blocos abatidos e espeleotemas vadosos caídos, que indicam que estas chaminés possuem trechos acima do nível d'água.

Os condutos em seção apresentam-se com forma elíptica, com scalops nas paredes e no teto.

Os condutos distribuem-se em um plano inclinado, possivelmente o plano de estratificação. Este plano teve direção calculada de N05E, obtida através da direção dos contornos das cotas do plano e mergutho de $25 \mathrm{NW}$ obtida através de trigonometria.

\section{Espeleogênese}

A origem destas nascentes está relacionada com a escarpa leste da Serra da Bodoquena. A água é captada através de injeção difusa na Unidade CLCP no planalto, onde percorre o maciço carbonático em circulação profunda, formando condutos e volta à superfície nas nascentes junto à escarpa. As nascentes do Sapo e do Fóssil encontram-se atualmente distantes da escarpa em cerca de $13 \mathrm{~km}$, e considera-se que a escarpa recuou deste ponto até sua posição atual.

Estas nascentes são do tipo vauclusiana, como já descrito por Kohler et al. (1998), isto é, apresentam artesianismo. Esta característica foi interpretada por Kohler et al. (1998) como causada pela diferença altimétrica entre a nascente e o rio. A estrutura deste setor é de um sinclinal os condutos são condicionados pelo mergulho dos calcários que estão situados no seu flanco leste, com direções de acamamento em torno de $\mathrm{N}$-S mergulhando para oeste (Anexos $5 a$ e b). Interpreta-se aqui que este artesianismo é gerado por camadas impermeáveis que se encontram estratigraficamente abaixo dos calcários (Anexos $5 a$ e b). Como a estrutura é de um sinclinal, as rochas impermeáveis estratigraficamente abaixo dos calcários estão situadas numa faixa a leste dos calcários, condicionando a subida abrupta da água. 
Verifica-se pelo desenvolvimento dos condutos da Nascente do Rio Formoso em um único plano que o acamamento é a estrutura que direciona o desenvolvimento da rede anastomosada, como observado em outras cavernas.

A Nascente do Rio Formoso é um conduto freático típico, não apresentando feições de exposição vadosa, como espeleotemas ou condutos em canyon. Assim acredita-se que estas nascentes são perenes mesmo em períodos de clima muito seco. Atualmente o nível d'água varia muito pouco nestas nascentes. 


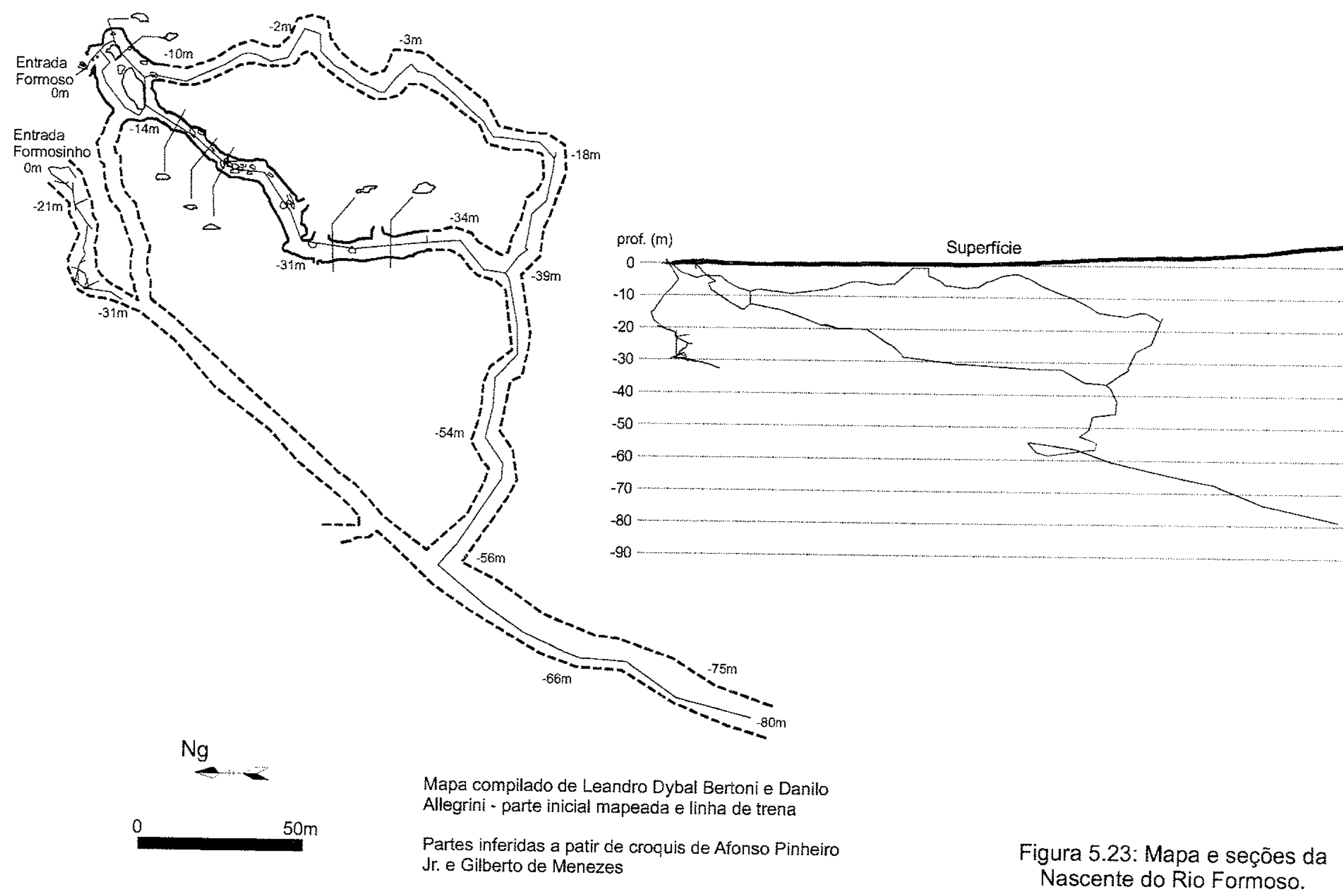




\section{Buraco do Sapo}
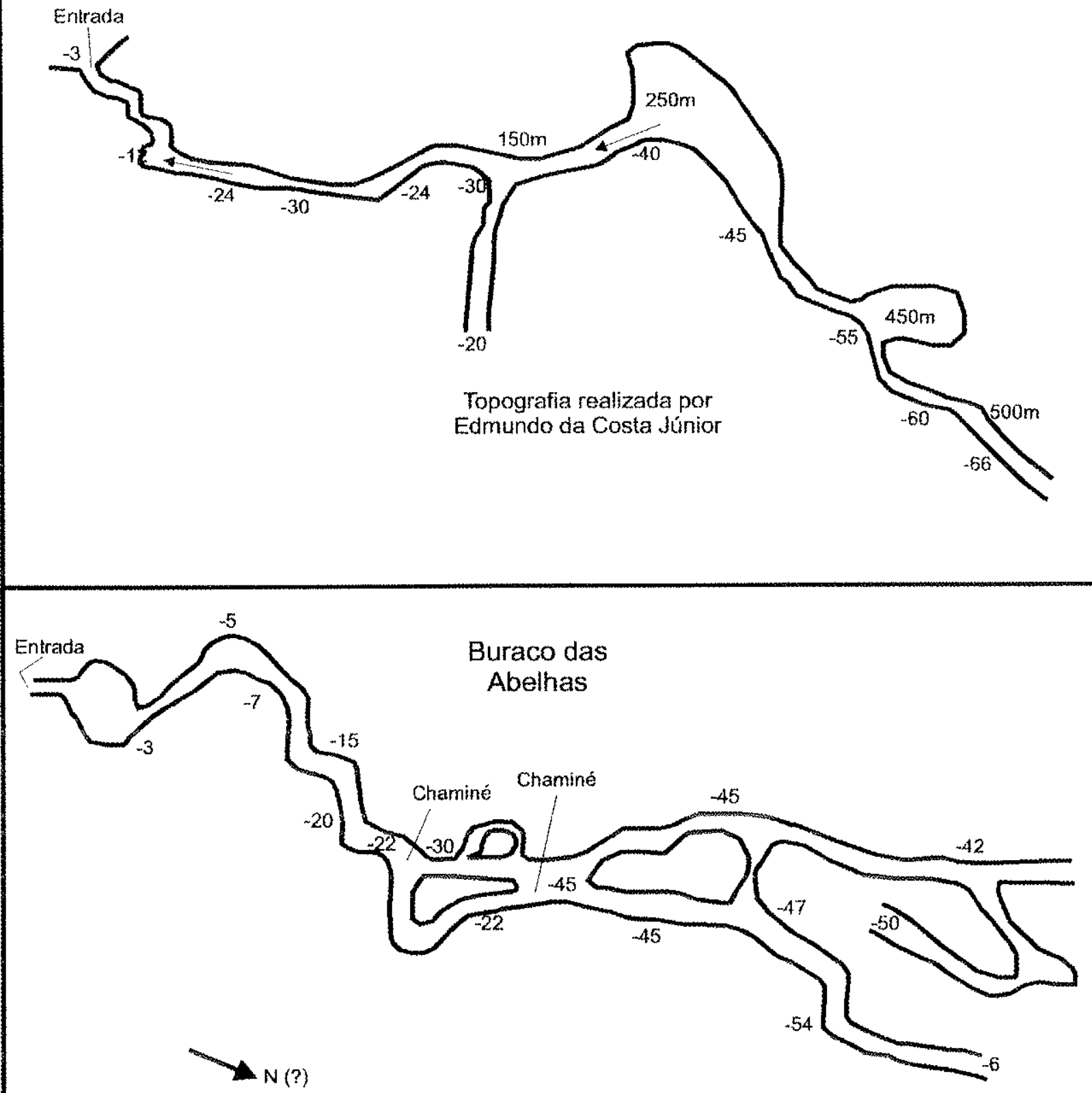

Topografia realizada por: Afonso Pinheiro Júnior

Gilberto Menezes

Edmundo da Costa Júnior

Figura 5.24: Croquis das nascentes do Buraco do Sapo e do Buraco das Abelhas. 


\section{TECTÔNICA RECENTE}

A evolução e conseqüente compartimentação morfológica do carste da Serra da Bodoquena foram controladas de forma significativa pelo movimento diferencial recente de blocos tectônicos.

A existência de tectônica recente é mostrada com base em duas constatações: 1) Presença de cavernas com espeleotemas vadosos atualmente submersos em profundidades de até $12 \mathrm{~m}$ abaixo do nível d'água médio (Figura 6.1A);2) Evidências geomorfológicas, especialmente a superfície escarpada de calcários do Planalto da Bodoquena soerguida em relação às rochas graníticas e dolomiticas (Figura 6.1B e C).

Outras feições como rios entalhados na porção norte da serra (Figura 6.1D) e uma estrutura linear de expressão regional também são indícios desta tectônica recente (Figura 6.1E). 


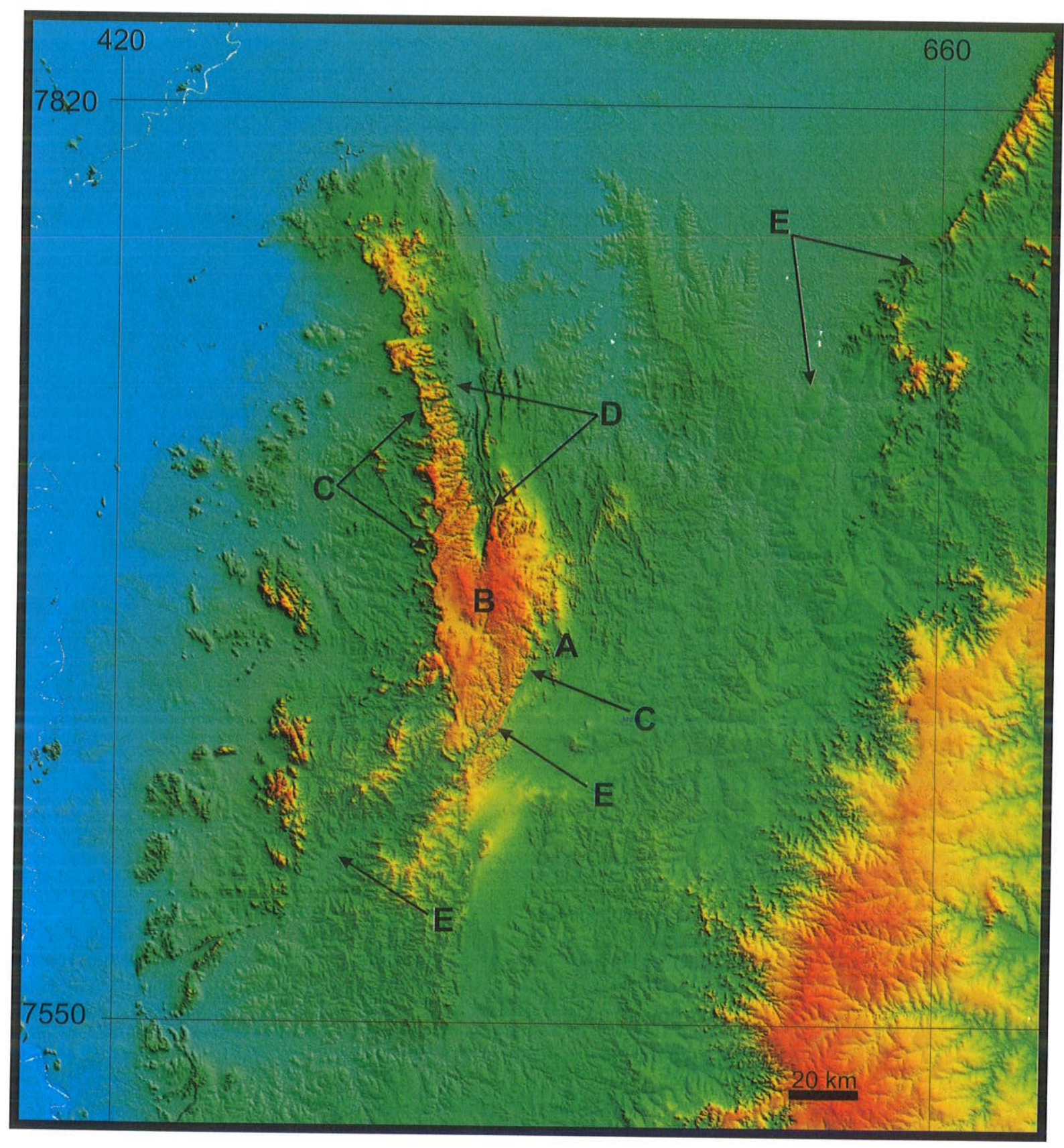

Figura 6.1: Principais feições que indicam movimentos tectônicos recentes na área (base imagem de radar SRTM, 2003). A- Cavernas com espeleotemas vadosos submersos; B- Planalto sustentado por calcários; C- Escarpas do Planalto da Bodoquena; D- Rios entalhados; E- Estrutura linear que cruza a Serra da Bodoquena. 


\subsection{Espeleotemas submersos}

Cavernas com lagos e espeleotemas, tanto subaquáticos (grandes cones e crostas) como submersos (estalagmites, estalactites e cortinas) são uma das características mais marcantes do carste da Serra da Bodoquena. Estes espeleotemas vadosos associados a grandes salões de abatimento, atualmente submersos, como observados nas cavernas Mimoso, Lago Azul e Anhumas, na Unidade PCMR, sugerem variações significativas do nivel d'água durante o Quaternário.

A influência tectônica no afogamento de espeleotemas vadosos nestas cavernas sempre foi objeto de discussão devido à subsidência do Pantanal Matogrossense. Porém sabe-se que durante o Quaternário ocorreram mudanças climáticas no planeta, e variações significativas do nível d'água podem ter ocorrido em fases mais secas e mais úmidas que a atual. Assim para detectar a possível influência tectônica e climática no afogamento de estalagmites, investigou-se estas cavernas, com o objetivo de relacionar a distribuição de espeleotemas submersos e subaquáticos com a variação sazonal do nivel d'água.

\subsubsection{Flutuação atual do nível d'água}

No sentido de estabelecer uma referencia quantitativa da flutuação sazonal atual do nível d'água nas cavernas onde foram estudados registros de espeleotemas vadosos (gerados em ambiente sub-aéreo) atualmente em condições submersas, foram instaladas réguas de referência para monitoramento desta oscilação ao longo de um ano hidrológico. Foram consideradas as grutas Mimoso, Lago Azul e Anhumas, nas quais foram coletados espeleotemas submersos.

O monitoramento da variação do nível d'água foi iniciado em julho de 2002, completando um ano em julho de 2003. Dados da estação pluviométrica 2156000 na cidade de Bonito, medidos pela Agência Nacional de águas (ANA http://hidroweb.ana.gov.br) foram utilizados para correlacionar a variação do nível d'água medida nas grutas com a pluviosidade. Os dados fornecem uma média de 1419 $\mathrm{mm}$ anual de chuvas em 24 anos de medição (Figura 6.2). Desta forma, os dados pluviométricos do ano de 2002, onde foi registrado o nivel d'água mais baixo durante o período medido, mostram um ano seco em relação ao total anual obtido de $912,8 \mathrm{~mm}$ (Figura 6.2). O valor total de pluviosidade obtido em 2002 também está abaixo do máximo registrado de $1954 \mathrm{~mm}$ total anual, no ano de 1991, mas não foi o periodo mais seco já registrado que alcançou $581,3 \mathrm{~mm}$ total anual, no ano de 1999 (Figura 6.2). 


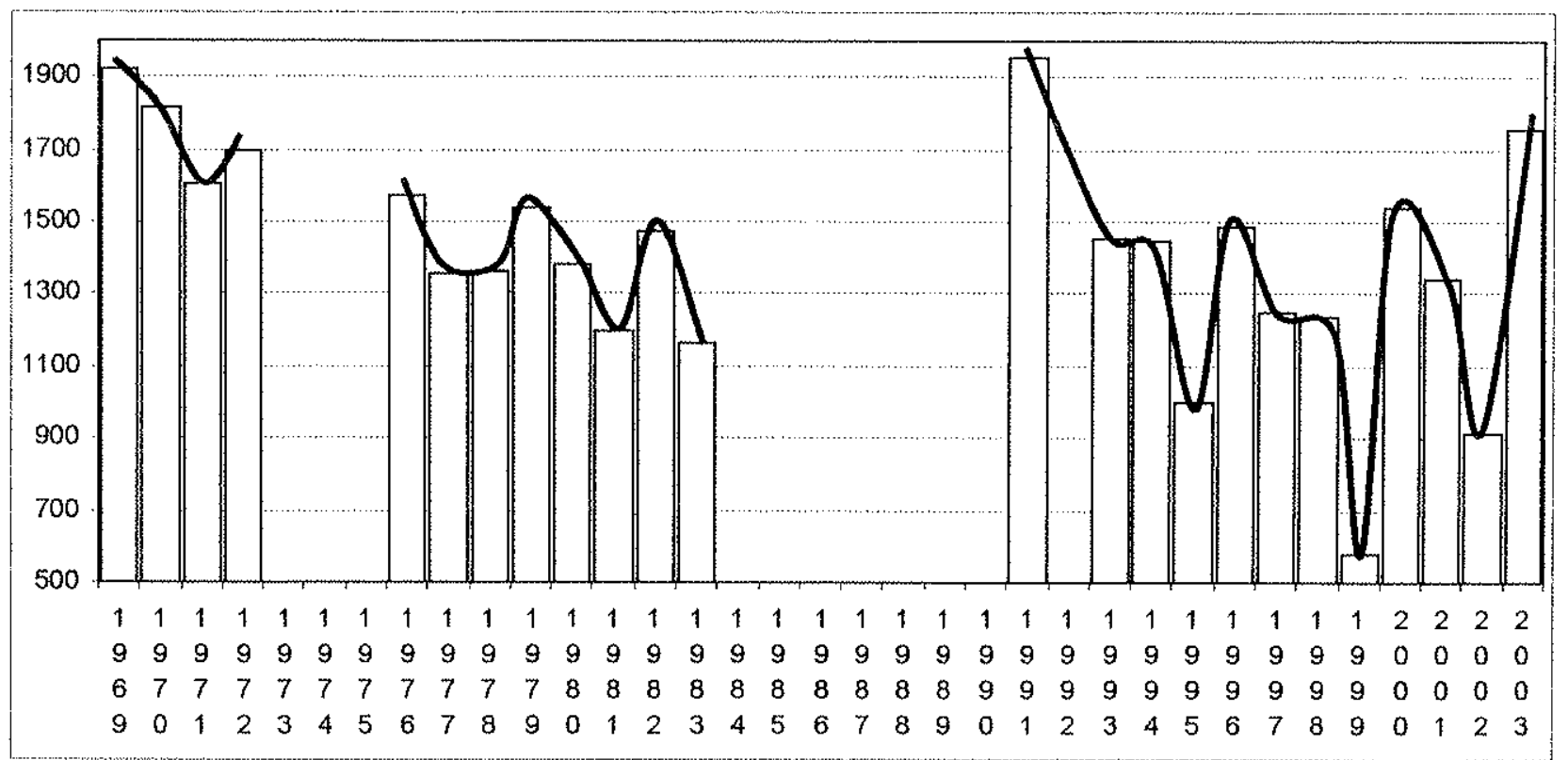

Figura 6.2: Totais anuais precipitados na estação pluviométrica de Bonito (MS), entre 1969 e 2003. Dados obtidos em: http://hidroweb.ana.gov.br.

A quantificação da variação atual do nível d'água foi necessária para estabelecer uma referência atual da influência climática sobre a flutuação do nível d'água, e assim permitir a detecção de espeleotemas vadosos, hoje em ambiente submerso, e que desta maneira poderiam indicar aumentos seculares do nivel d'água, causadas por subsidência tectônica da área ou mudanças climáticas, com períodos secos associados a posições inferiores do nivel d'água. A distinção entre processos tectônicos e climáticos causando a oscilação do nivel d'água é obtida através do estabelecimento de uma variação máxima causada por influência climática, com base no monitoramento atual do nivel d'água, onde estalagmites submersas em profundidades superiores que este máximo climático refletem afogamento por subsidência tectônica.

A Gruta Lago Azul teve sua régua calibrada conjuntamente com a do Abismo Anhumas, pois as cavernas são muito próximas. No mesmo dia da colocação da régua na Gruta Lago Azul foi medida a altitude do nivel d'água nestas duas cavernas, utilizando o altímetro barométrico do GPS, que mostrou que ao menos no dia da medição, o nivel d'água nas duas cavernas estava praticamente na mesma altitude, considerando os erros de medição.

Além da medição das réguas foram avaliados os registros históricos das épocas de chuvas e secas extremas, obtidos com moradores e pessoas que presenciaram estes eventos. Os registros históricos são importantes, pois marcam o máximo e o mínimo, que provavelmente não serão registrados no período de monitoramento pelas réguas. 
A amplitude da variação registrada foi de cerca de $3 \mathrm{~m}$ na Gruta Lago Azul, $10 \mathrm{~m}$ na Gruta Mimoso e $3 \mathrm{~m}$ no Abismo Anhumas no período de julho de 2002 a julho de 2003. No Abismo Anhumas existem registros desde 21/10/2001 e se considerado desde esta data, obtém-se cerca de 4,5 m. Conforme já descrito no Capítulo 5.3.4.1, observase um comportamento muito semelhante na variação do nível d'água nas grutas Lago Azul e Anhumas (Figura 5.14).

Os gráficos com os dados de variação do nivel d'água nas grutas Mimoso, Lago Azul e Anhumas juntamente com dados de pluviosidade, demonstram que o nivel d'água sobe exponencialmente após o início do periodo das chuvas (Figura 6.3). Um fato importante, ainda não interpretado, é a grande diferença de variação do nível d'água entre as áreas das grutas Lago Azul e Mimoso, exemplificando que não se pode generalizar a variação do nível d'água ao longo de um aqüífero cárstico com base em um ponto monitorado. 

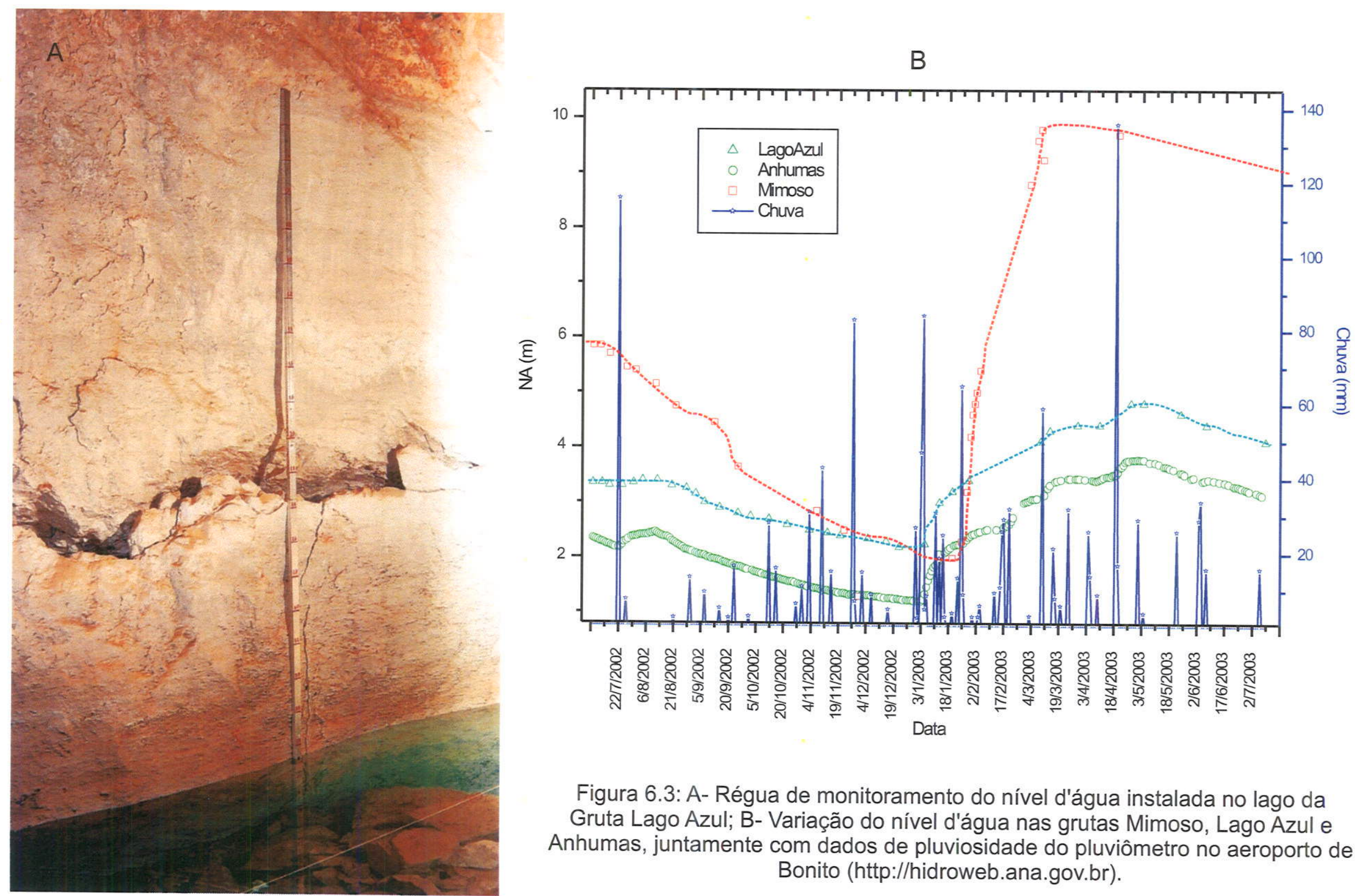

Figura 6.3: A- Régua de monitoramento do nível d'água instalada no lago da Gruta Lago Azul; B- Variação do nível d'água nas grutas Mimoso, Lago Azul e Anhumas, juntamente com dados de pluviosidade do pluviômetro no aeroporto de Bonito (http://hidroweb.ana.gov.br). 


\subsubsection{Flutuação antiga do nível d'água}

Espeleotemas vadosos submersos e subaquáticos presentes nas grutas Mimoso, Lago Azul e Anhumas registram importantes eventos de variação do nivel d'água. Estes espeleotemas foram analisados e 21 amostras foram coletadas a fim de compreender estas variaçōes (Tabela 6.1).

A profundidade de cada amostra coletada foi medida utilizando profundímetro, onde o "zero" é sempre o nível d'água do momento da medição. Como o nível d'água varia ao longo do ano, estas medidas de profundidade foram referenciadas com bases topográficas fixas nas grutas, além das réguas de monitoramento.

Para uma melhor compreensão da distribuição dos espeleotemas submersos e das amostras coletadas foi elaborado um quadro (Figura 6.4) onde os dados de profundidade foram normalizados em relação a um datum (nivel médio em relação ao nível máximo e mínimo do nível d'água no período de 12 meses).

Através do registro da flutuação atual do nivel d'água na Gruta Mimoso, identificouse espeleotemas vadosos desde acima do nivel d'água máximo, e até $16 \mathrm{~m}$ abaixo do nivel d'água mínimo (Figuras 6.5D e E), ou seja, atualmente estes espeleotemas submersos mais profundos não emergem durante os períodos mais secos. Já os espeleotemas subaquáticos, como crostas e cones, ocorrem desde $5 \mathrm{~m}$ até mais de 40 m abaixo do nível d’água mínimo. 
Tabela 6.1: Listagem das amostras de espeleotemas coletados para o estudo de registro da flutuação antiga do nível d'água.

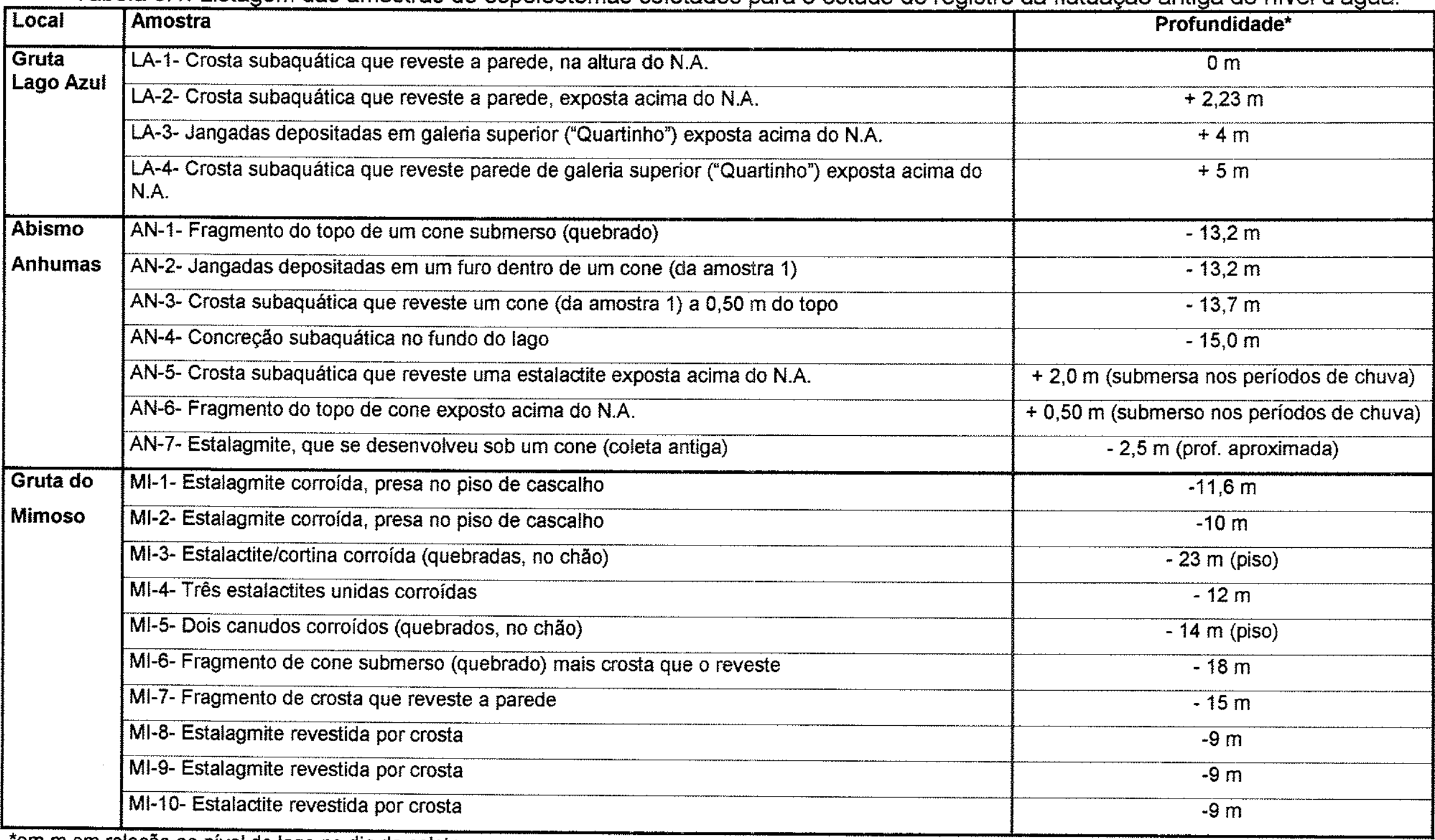

${ }^{*} \mathrm{em} \mathrm{m}$ em relação ao nível do lago no dia da coleta. 


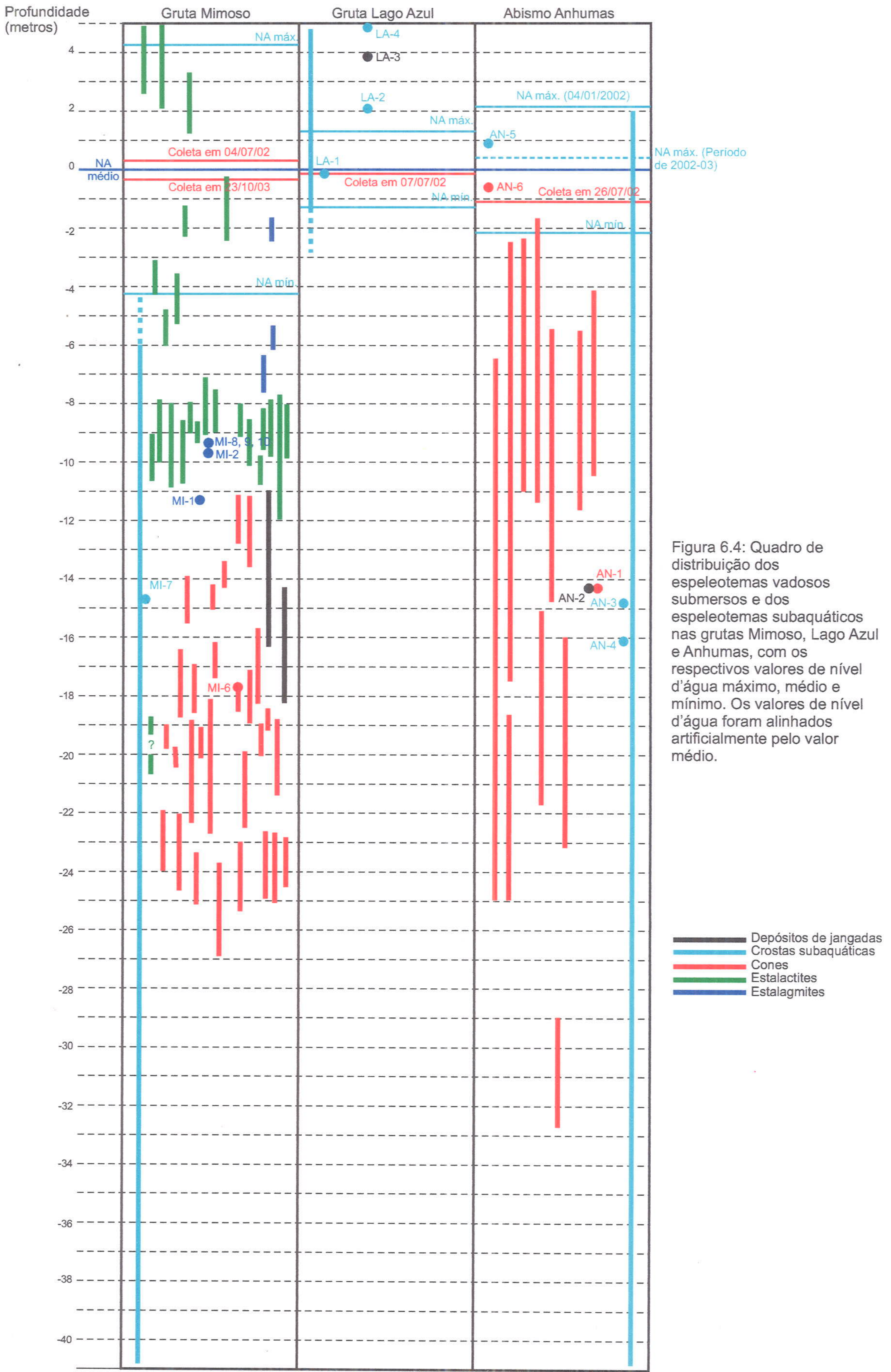




\subsubsection{Petrografia e gênese dos espeleotemas analisados}

Os espeleotemas vadosos submersos e os subaquáticos presentes nas grutas Mimoso, Lago Azul e Anhumas foram estudados para compreender sua gênese e para verificar sua utilidade no estudo da variação do nível d'água. A gênese destes espeleotemas nunca foi abordada anteriormente com detalhe. Além de análises de laboratório de 21 amostras foram realizadas filmagens, fotografias e medições destes espeleotemas através do apoio de mergulhadores.

As estalactites submersas ocorrem principalmente nas grutas Mimoso e Anhumas. $\mathrm{Na}$ Gruta Lago Azul ocorrem apenas na zona de oscilação do nivel d'água e em pouca profundidade. Na Gruta Mimoso ocorrem estalactites na porção seca da caverna, na zona de oscilação do nível d'água e submersas mesmo nos períodos mais secos (Figura 6.4). Quando submersas encontram-se em profundidades de até $-16 \mathrm{~m}$ (Figuras $6.5 \mathrm{C}$ e D) abaixo do nivel d'água mínimo. Possuem até $5 \mathrm{~m}$ de comprimento, podendo ou não estar recobertas por crostas (Figura 6.5). As amostras de estalactites coletadas, não estavam cobertas por crosta e encontram-se alteradas nas bordas.

As estalagmites submersas ocorrem principalmente nas grutas Mimoso e Anhumas. Não foram registradas estalagmites na Gruta Lago Azul. Na Gruta Mimoso as estalagmites possuem até $1 \mathrm{~m}$ de altura (Figura 6.6A) e ocorrem até $.12 \mathrm{~m}$ abaixo do nível d'água mínimo. São laminadas, com evidências de dissolução (laminação interna exposta - Figuras $6.6 \mathrm{~A} \mathrm{e} \mathrm{C}$ ) e compostas de lâminas de calcita e aragonita intercaladas. Ocorrem também recobertas por crostas (Figura 6.6B) e apresentam bordas alteradas (Figura 6.6D), especialmente quando não recobertas por crostas. Porém algumas amostras de estalagmites recobertas por crosta encontravam-se alteradas e praticamente ocas em certos pontos (Figura 6.8D e E). Na amostra MI-9 verificou-se que a crosta encontra-se depositada em discordância com a estalagmite, indicando que houve primeiro a dissolução da estalagmite e posteriormente o recobrimento pela crosta (Figura 6.8G). No Abismo Anhumas ocorrem estalagmites com forma diferente do usual, se assemelhando a "pilhas de copos" (Figura 6.6E). Estas estalagmites parecem ser constituidas de aragonita que quando alteradas desenvolvem "placas" que se projetam radialmente do centro em direção as bordas. Posteriormente uma crosta subaquática recobre estas estalagmites alteradas configurando as formações atualmente observadas. Observou-se também no Abismo Anhumas uma estalagmite do tipo vela com cobertura por crosta, mais espessa na base do que no topo (Figura 6.6F). Esta vela encontra-se na zona de oscilação do nivel d'água e acredita-se que no ponto onde a crosta muda de espessura seja o marco do nível d'água médio (Figura 6.6G), ou seja, 
deste ponto para baixo a vela passa a maior parte do tempo submersa e apenas em anos mais chuvosos ela fica recoberta até o topo.

Dentre os espeleotemas observados destacam-se as crostas subaquáticas e os cones das grutas Mimoso e Anhumas.

As crostas subaquáticas são muito comuns e bastante espessas nas grutas Mimoso e Anhumas Já na Gruta Lago Azul, elas são finas (Figuras 6.8A e B) e se restringem à parte mais rasa do lago e na parte exposta na época do nível d'água mais baixo. Cobrem todas as paredes e os espeleotemas vadosos a partir de uma certa profundidade (cerca de $8 \mathrm{~m}$ na Gruta Mimoso) (Figuras 6.7). Recobrem também os cones (Figura 6.9). Apresentam textura superficial suavemente arredondada (Figura 6.7). Apresentam também texturas do tipo "folhas" (Figura 6.7F) ou semelhante a coralóides (Figuras $6.8 \mathrm{~F}, \mathrm{G}$ e J). As maiores espessuras observadas são de até $10 \mathrm{~cm}$ (Figura 6.7D), mas devem alcançar espessuras maiores. Na Gruta Mimoso ocorre trechos onde a crosta apresenta-se descolada expondo a rocha (Figuras 6.7D e F). Apresentam laminação milimétrica (Figuras $6.8 \mathrm{C}, \mathrm{H}, \mathrm{I}$ e J) sendo compostas por calcita (Figura 6.11A).

Os cones ocorrem nas grutas Mimoso e Anhumas (Figura 6.12). Estes cones presentes nas grutas Mimoso e Anhumas chamam a atenção pelo tamanho e quantidade, podendo representar o sítio mundialmente mais importante deste tipo de espeleotema.

$\mathrm{Na}$ Gruta do Mimoso existem cones em diversos locais e profundidades, a partir de $-10 \mathrm{~m}$ até cerca de $-36 \mathrm{~m}$ abaixo do nível d'água mínimo (Figuras 6.4 e 6.12). Destacase na Gruta Mimoso o "Salão dos Cones" onde existem diversos cones agrupados a profundidades de -20 a $-35 \mathrm{~m}$ (Figuras $6.9 \mathrm{~A}$ e B), onde os maiores alcançam até $7 \mathrm{~m}$ de altura e $2 \mathrm{~m}$ de diâmetro. No Abismo Anhumas ocorrem cones também a diversas profundidades, porém os maiores cones observados nesta caverna (de até $19 \mathrm{~m}$ de altura - Auler et al., 2001b) (Figura 6.10A). Encontram-se alinhados como observados na Gruta Mimoso (Figura 6.9B) e Abismo Anhumas. Nos cones analisados observa-se uma estrutura interna foliada, gerada pelo acúmulo das placas de calcita (jangadas) (Figuras 6.9C, F, G, H, 6.10E, 6.11B e C). Isto também é visto em corte (Figura 6.9H), em lâmina petrográfica e em MEV (Figura 6.11D). Crostas recobrem os cones e preenchem os espaços vazios entre as placas (Figuras 6.9A, B, E e H). No Abismo Anhumas, durante os meses de seca, afloram alguns pequenos cones que ainda estão em formação (Figuras 6.10B, C, D e F). 
Crostas e cones são espeleotemas subaquáticos relatados em algumas cavernas no mundo, tanto em ambientes termais como de circulação meteórica (Hill \& Forti, 1997), porém não são espeleotemas comuns. A origem dos cones e também dos chamados "vulcões" é atribuída a gotejamentos sobre jangadas na superfície de um corpo aquoso, formando pilhas de jangadas em forma de cones ou vulcões (Hill \& Forti, 1997). A forma de vulcão (com uma depressão no centro) é devido ás ondulações na superfície do corpo aquoso (Baker \& Proctor, 2000). Baker \& Proctor (2000) denominam estes vulcões de "estalagmites subaquáticas", e embora este nome seja sugestivo ele causa uma certa confusão, pois as estalagmites são estruturas já definidas como de origem subaérea. Cones e vulcões são gerados em águas paradas ou muito calmas, como lagos e represas de travertinos. Os vulcőes apresentam estrutura interna semelhante à dos cones, conforme pode ser observado em amostra de vulcão da Gruta Cinco de Ouros. A diferença entre cones e vulcões é o tamanho e a forma que estão associados à profundidade do corpo aquoso, distância do topo da formação até a superfície da água (espessura da lâmina d'água) e altura do gotejamento.

Assim para a formação de um cone é necessário que exista um lago, ou seja, é necessária uma superfície para ocorrer o gotejamento e deposição das jangadas. Em uma caverna totalmente submersa não ocorreria a formação de cones. No Abismo Anhumas existe um lago atualmente e o gotejamento ainda ocorre, possibilitando a formação de cones. Já a Gruta Mimoso encontra-se em grande parte submersa. A superfície do lago ocorre apenas na entrada e em um salão seco no fundo da caverna, onde não ocorrem cones. A origem dos cones da Gruta Mimoso pode ser interpretada de duas formas. Em chaminés descobertas recentemente afloram a superficie do lago onde pode ocorrer o gotejamento, gerando a deposição de jangadas logo abaixo. Porém esta hipótese não contempla os cones e depósitos de jangadas que não ocorrem abaixo das chaminés. A outra possibilidade é de que os cones marcam a subida do lago, tendo sido gerados com o nivel d'água mais baixo, com a superfície do lago abaixo da zona de deposição de espeleotemas vadosos (atualmente submersos) possibilitando o gotejamento. Observamse que ocorrem cones abaixo de estalactites atualmente submersas em alguns pontos e Cones alinhados, que podem ser relacionados a alinhamentos de gotejamentos em fraturas. As marcas de variação do nível d'água podem ser vistas em alguns locais, nas crostas subaquáticas na Gruta Mimoso. 

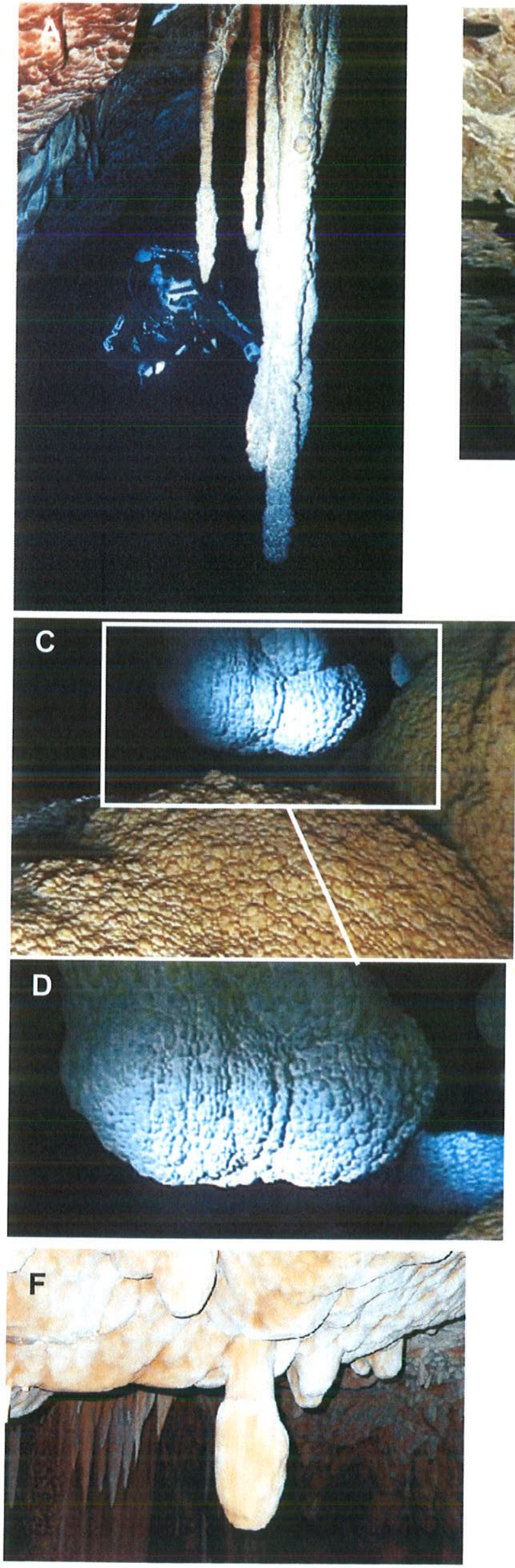
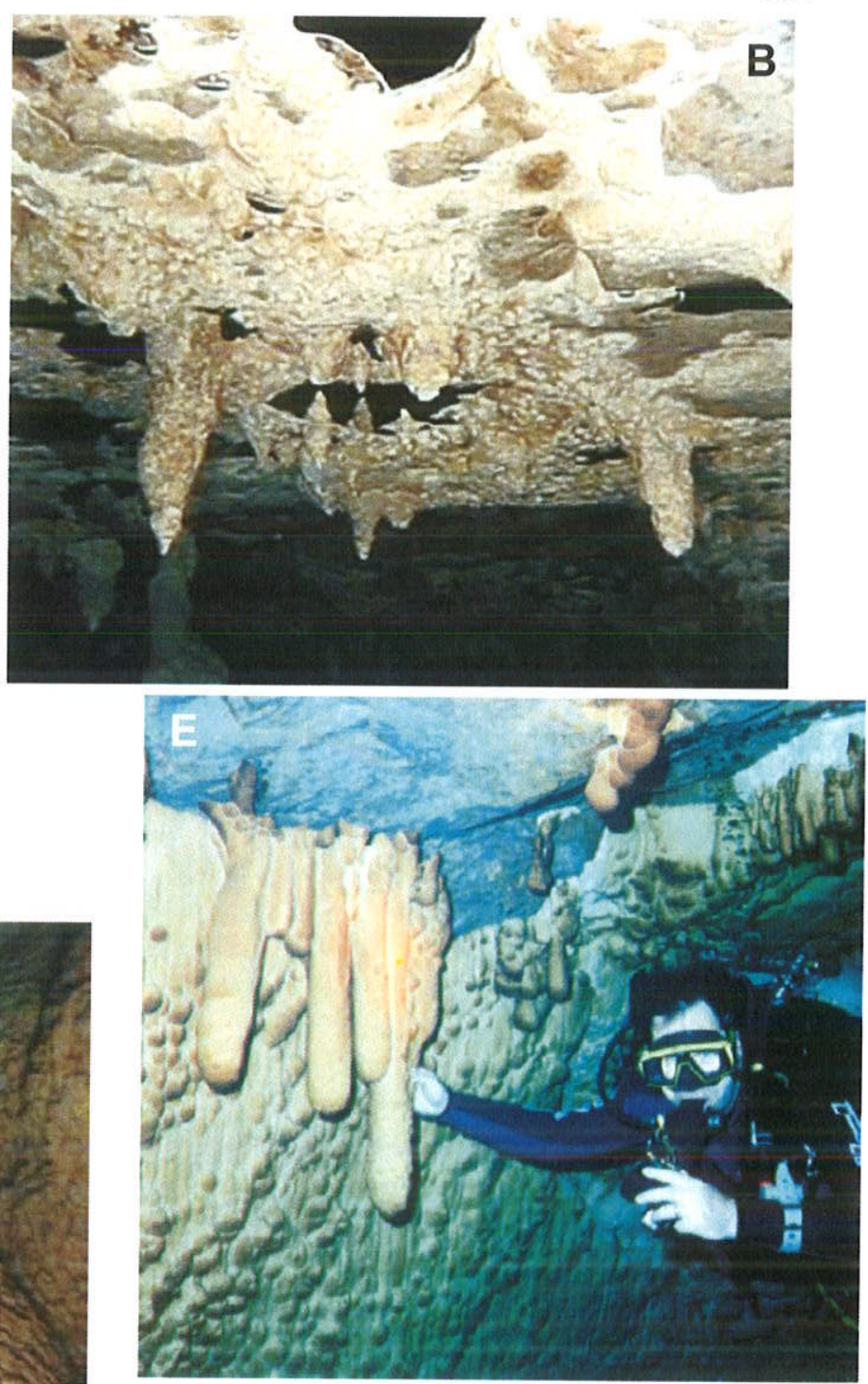

Figura 6.5: Estalactites submersas. Gruta Mimoso: A- Estalactite revestida por crosta subaquática $(-12 \mathrm{~m})$; B- Estalactites revestidas por crosta subaquática, em teto irregular, com bolhas de ar aprisionadas (aprox. -8m); C- Provável estalactite revestida por crosta (aprox. -20m); GDetalhe de C; E- Estalactites revestidas por crosta subaquática, tipo "clava" ($12 \mathrm{~m})$, e teto sem crosta. Abismo Anhumas: F- Estalactites revestidas por crosta subaquática, tipo "clava", expostas com o nível d'água baixo. Fotos: A e EIsmael Escote; B a D- Marcos Philadelphi (vídeo). 

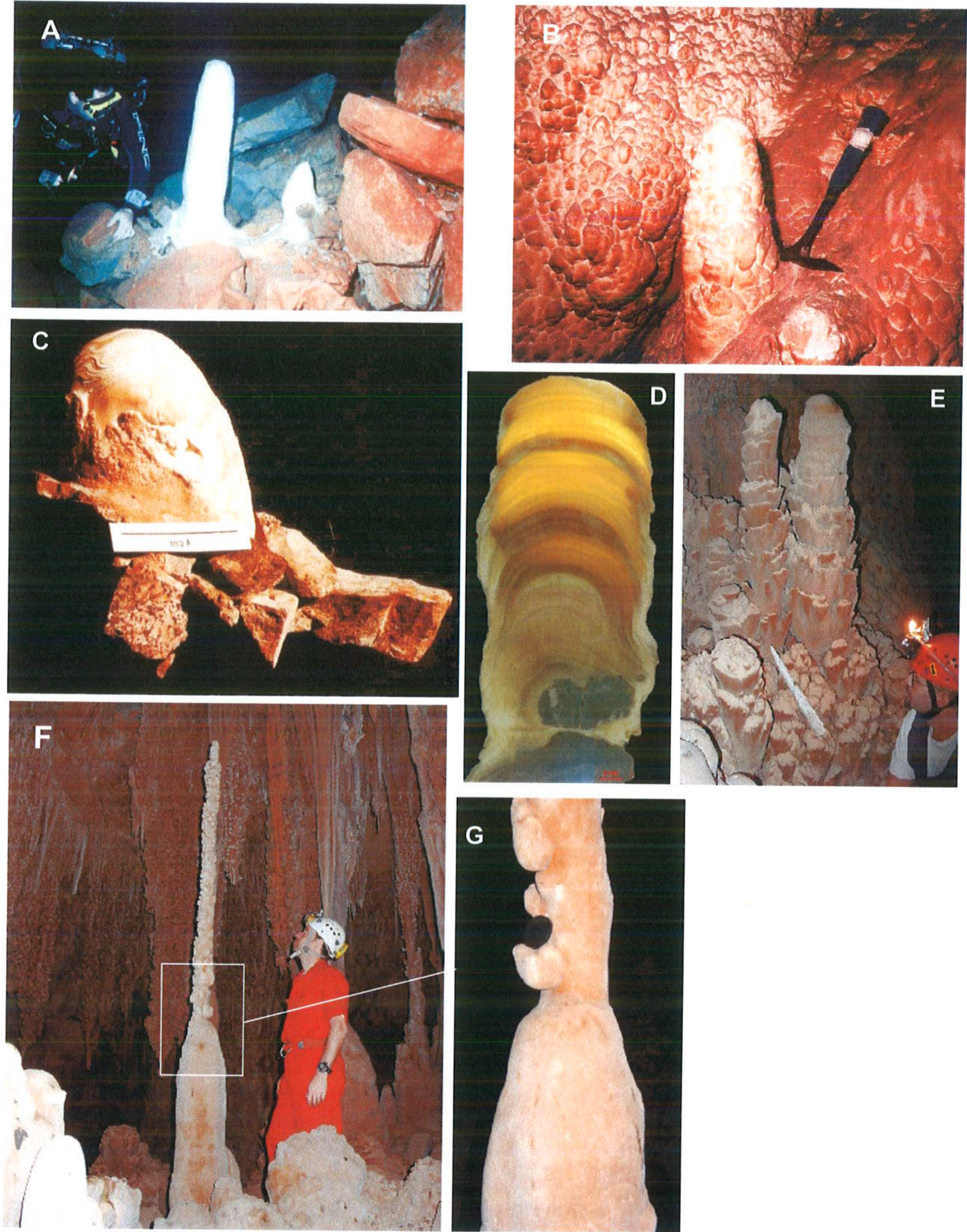

Figura 6.6: Estalagmites.Gruta Mimoso: A- Estalagmites alteradas sobre blocos desmoronados $(-10 \mathrm{~m})$; B- Estalagmite revestida por crosta subaquática $(-11 \mathrm{~m})$. CAmostra de estalagmite (Ml-1) coletada a -11,6 m; D- Amostra de estalagmite (MI-2) coletada a -10 m, exibindo bordas alteradas. Abismo Anhumas (exposto com nível d'água baixo): E- Estalagmite alterada revestida por crosta; F- Base de estalagmite tipo vela espessada pela cobertura de crosta; G- Detalhe de F. Fotos: A e B- Ismael Escote. 

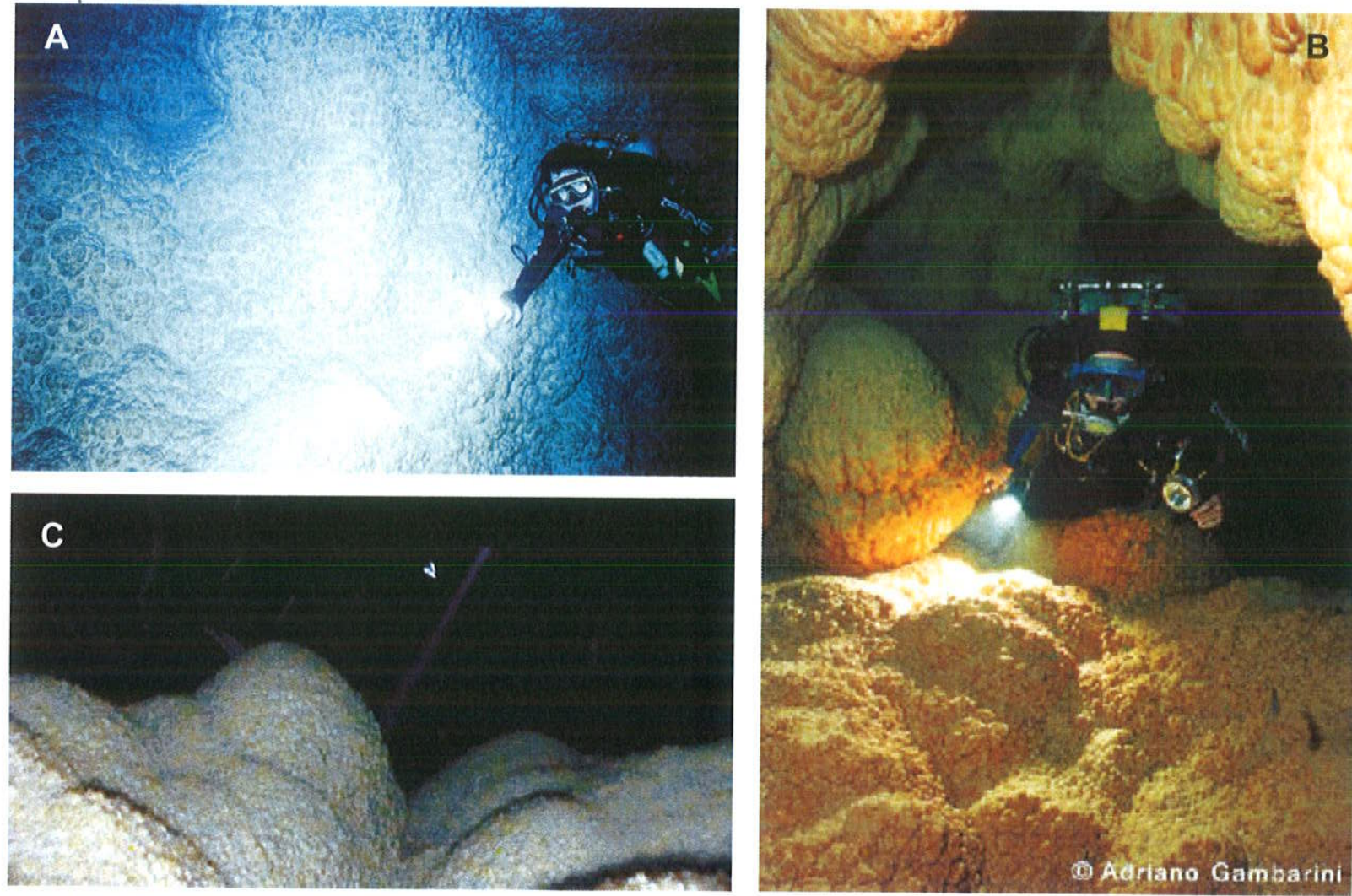

(4) Adriano Gambarini
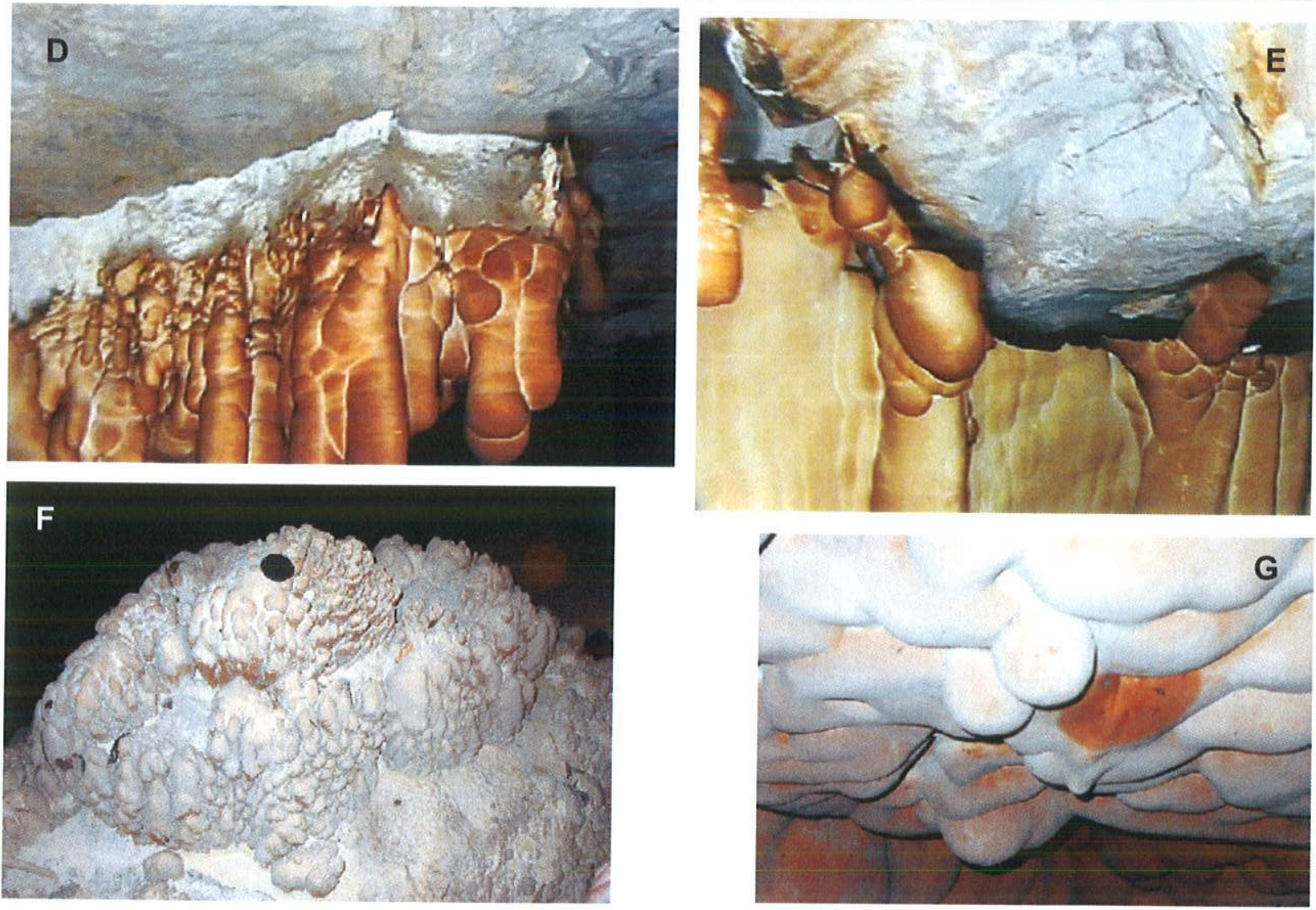

Figura 6.7: Crostas subaquáticas. Gruta Mimoso: A- Parede revestida por crostas com textura arredondada (-19m); B- Salão preenchido por crostas (-20m); C- "Domos" (aprox. $-20 \mathrm{~m}$ ); D e E- Crosta subaquática parcialmente descolada do teto, expondo rocha ($12 \mathrm{~m})$. Abismo Anhumas: F- Crostas do tipo "folhas"; G- Crostas com textura arrendada. Fotos: A- Ismael Escote; C, D e E- Marcos Philadelphi (vídeo); B- Adriano Gambarini. 

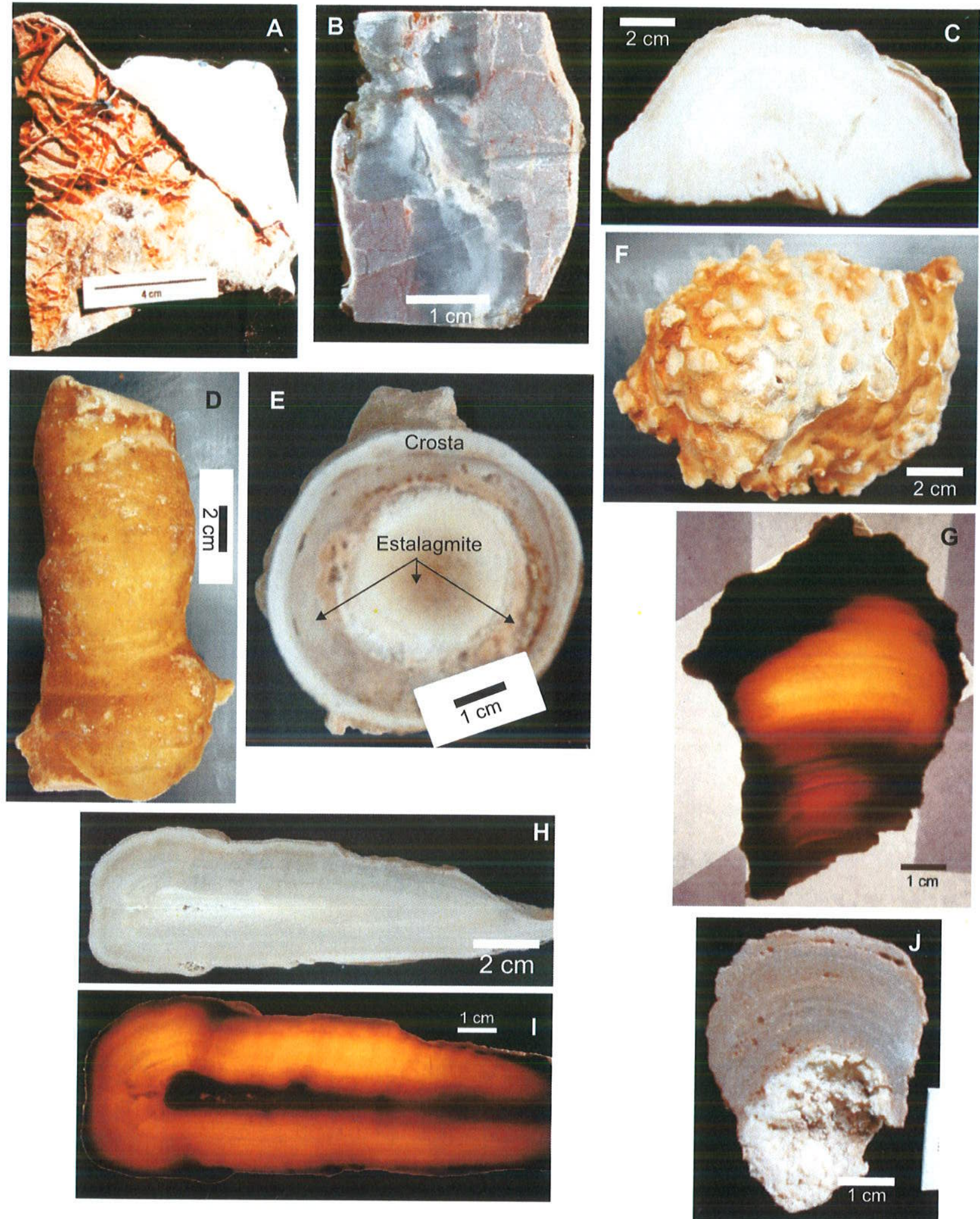

Figura 6.8: Crostas subaquáticas. Gruta Lago Azul: A- Crosta que reveste a parede na altura do nível d'água (Amostra LA-1); B- Fragmento de dolomito com veios de quartzo com revestimento de crosta (Amostra LA-2, + 2,23m). Gruta Mimoso: C- Crosta que revestia a parede (Amostra MI-7, $-15 \mathrm{~m}$ ); D- Estalagmite revestida por crosta (Amostra Ml-8, - 9m); E- Detalhe de D, em corte longitudinal, onde fica evidente o revestimento de crosta; F- Estalagmite revestida por crosta com textura "coralóide" (Amostra MI-9, $-9 \mathrm{~m}$ ); G- Fotografia em luz transmitida de corte transversal da estalagmite de F, onde a crosta aparece escura na parte superior; $\mathrm{H}$ e I- Estalactite revestida por crosta em corte transversal em fotografia em luz refletida $(\mathrm{H})$ e transmitida (I). Abismo Anhumas: JCrosta com forma "coralóide" em corte transversal (Amostra AN-4, -15m). 

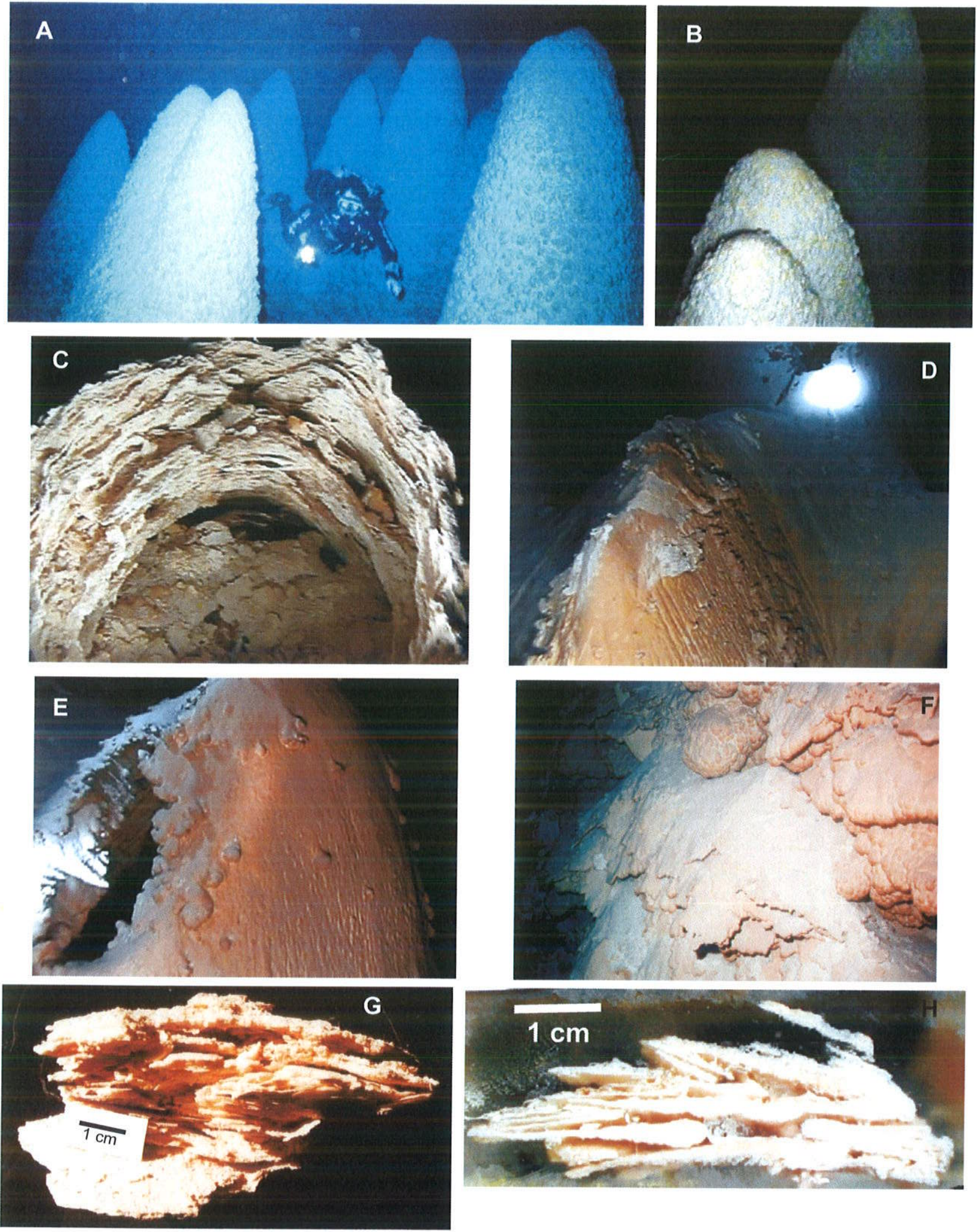

Figura 6.9: Cones da Gruta Mimoso. A- Cones revestidos por crosta (topo - $26 \mathrm{~m}$ e base $20 \mathrm{~m})$; B- Cones alinhados; C- Cone quebrado evidenciando estrutura interna (-17m); D-

"Crista" em depósito de jangadas com crosta; E- Detalhe de D aonde se observa a deposição de crostas no interior oco de uma "crista"; F- Placas (jangadas) acumuladas em parede inclinada; G- Fragmento de cone exibindo placas empilhadas (Amostra MI-6, $-18 \mathrm{~m}$ ); H- Fragmento de cone (Foto G - em corte de amostra impregnada) com placas empilhadas e crosta nos espaços vazios entre as placas.Fotos: A- Ismael Escote; B a FMarcos Philadelphi (vídeo). 

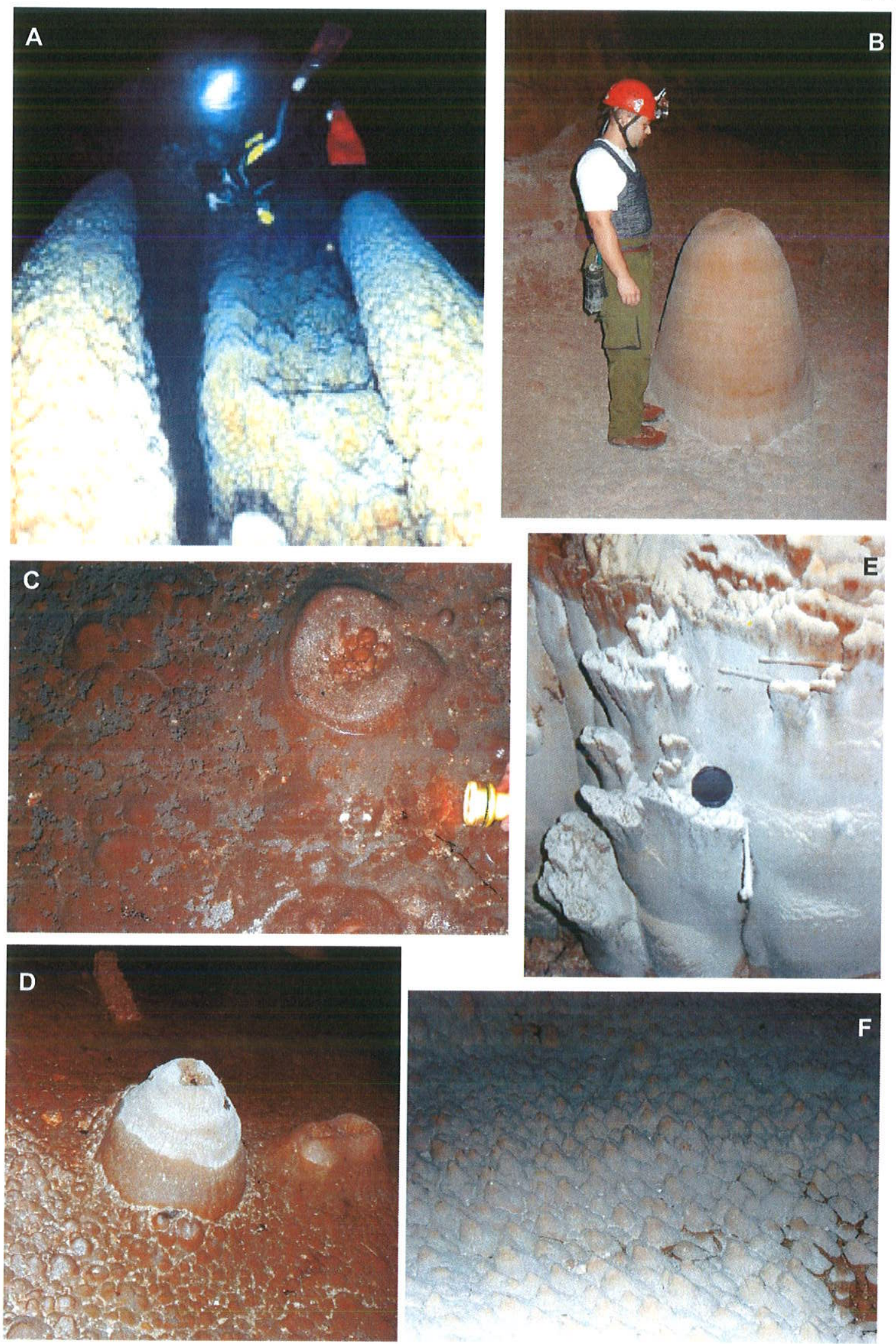

Figura 6.10: Cones no Abismo Anhumas. A- Cones de grandes dimensões (base a cerca da -26m); B- Cone pequeno exposto com o nível d'água baixo; C e D- Cones (ou vulcões) em formação em pequeno lago com jangadas exposto com o nível d'água baixo; E- Jangadas depositadas em estalagmite alterada; F-Piso com pequenos cones pequenos assimétricos expostos com o nível d'água baixo. 


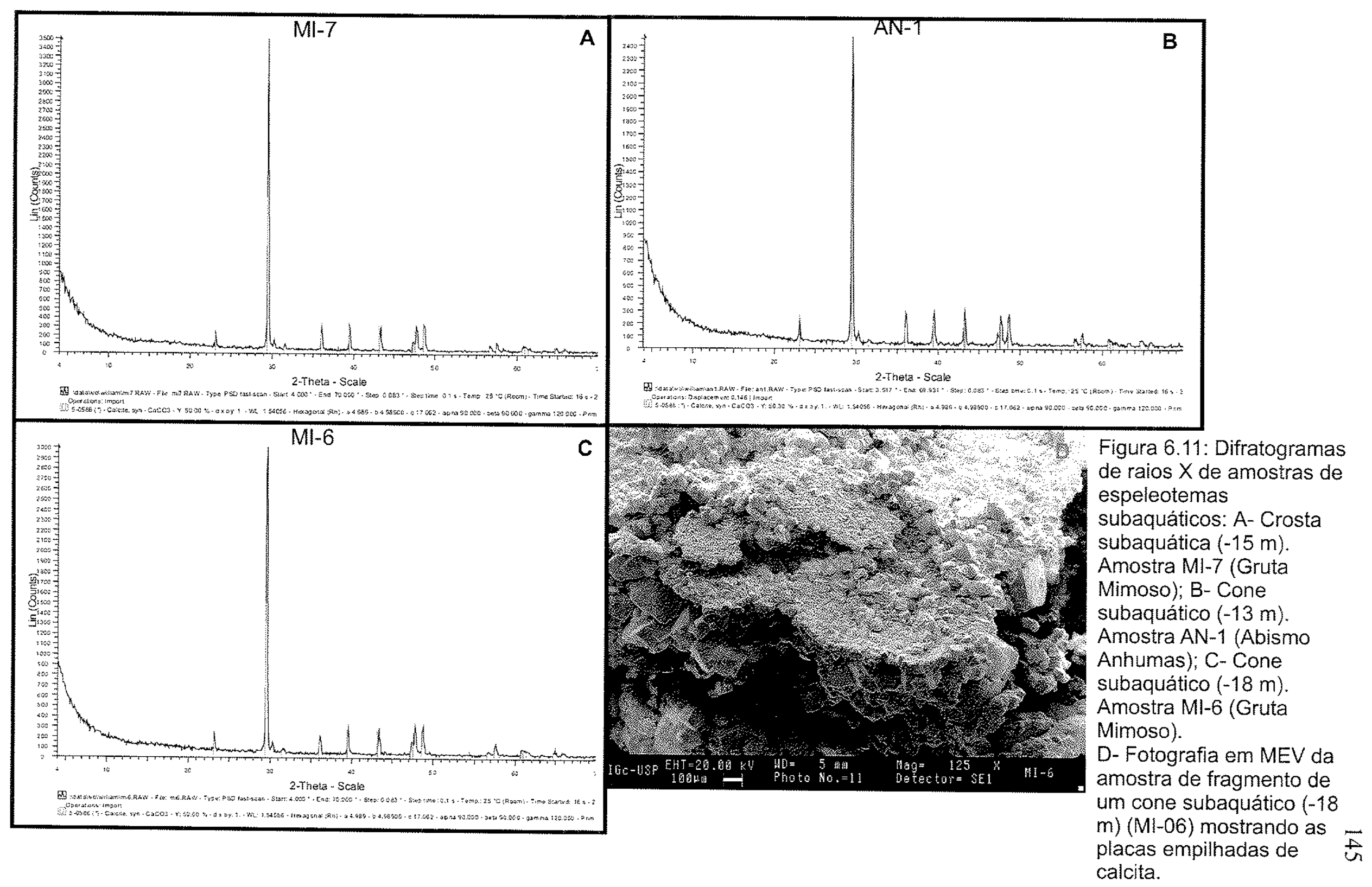




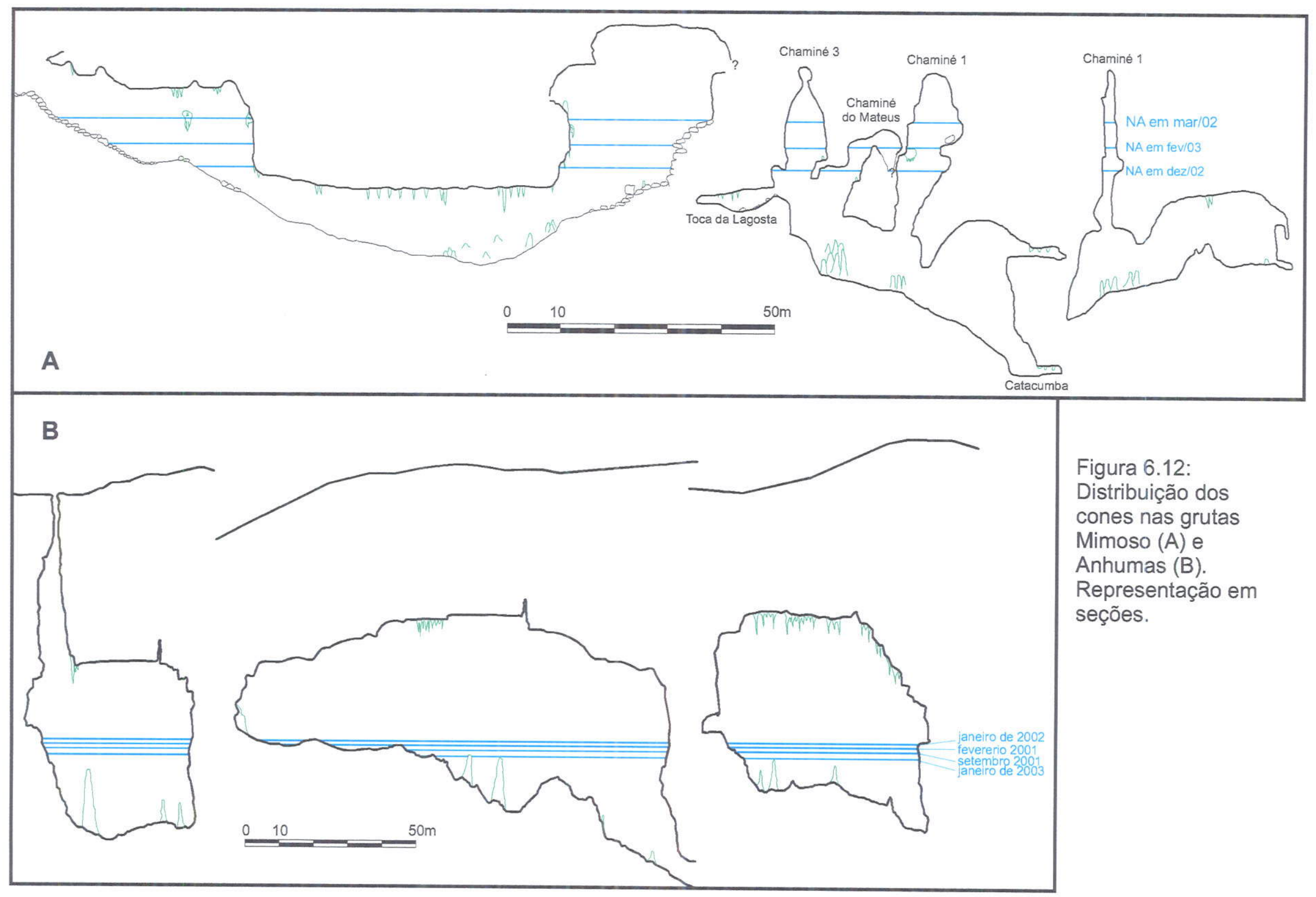

के 


\subsubsection{Geocronologia}

Dentre as 21 amostras coletadas algumas foram selecionadas para datação utilizando como critérios a alteração (observada em lâmina petrográfica) e os teores em $\mathrm{U}$. Os resultados mostram que alguns espeleotemas subaquáticos possuem teores em $\mathrm{U}$ mais baixos que a maioria dos espeleotemas vadosos.

Verificou-se que muitos espeleotemas vadosos submersos encontram-se alterados de forma total ou apenas nas bordas. Foram descartados para datação espeleotemas com alteração interna, assim como, as bordas alteradas de espeleotemas internamente intactos. As bordas alteradas apresentam enriquecimento de $\mathrm{U}$ (Tabela 6.2).

$\mathrm{Na}$ Gruta Mimoso a mesma água que está precipitando os espeleotemas subaquáticos também está alterando os espeleotemas vadosos, possivelmente devido a sua composição mineral distinta, de calcita para os subaquáticos e aragonita para os vadosos. Isto é um ponto negativo para a datação, pois a alteração pode ter modificado estes espeleotemas.

Devido a isto preferiu se coletar espeleotemas vadosos revestidos por crosta subaquática que geralmente preservam o espeleotema vadoso da alteração subaquática. Além disso, a datação do espeleotema vadoso associada à datação da crosta fornece uma idade precisa da subida do nivel d'água.

Tabela 6.2: Resultados da análise dos teores de urânio em espeleotemas pelo método de ativação neutrônica, realizado pelo IPEN-USP.

\begin{tabular}{|c|c|c|c|}
\hline Local & Amostra & Profundidade $^{*}$ & Teor de Urânio \\
\hline $\begin{array}{l}\text { Gruta } \\
\text { Lago Azul }\end{array}$ & $\begin{array}{l}\text { LA-1- Crosta subaquática que reveste a } \\
\text { parede, na altura do N.A. } \\
\text { LA-2- Crosta subaquática que reveste a } \\
\text { parede, exposta acima do N.A. }\end{array}$ & $\begin{array}{c}0 \mathrm{~m} \\
+2,23 \mathrm{~m}\end{array}$ & $\begin{array}{c}230 \pm 61 \mathrm{ng} / \mathrm{g} \\
2,3 \pm 0,61 \mathrm{ppm} \\
<10 \mathrm{ng} / \mathrm{g} \\
0,1 \mathrm{ppm} \\
\end{array}$ \\
\hline $\begin{array}{l}\text { Abismo } \\
\text { Anhumas }\end{array}$ & $\begin{array}{l}\text { AN-1- Fragmento do topo de um cone } \\
\text { submerso (quebrado) } \\
\text { AN-5- Crosta subaquática que reveste uma } \\
\text { estalactite exposta acima do N.A. }\end{array}$ & $\begin{array}{c}-13,2 \mathrm{~m} \\
+2,0 \mathrm{~m} \\
\text { (submersa nos } \\
\text { periodos de } \\
\text { chuva) }\end{array}$ & $\begin{array}{c}83 \pm 10 \mathrm{ng} / \mathrm{g} \\
0,83 \pm 0,1 \mathrm{ppm} \\
286 \pm 11 \mathrm{ng} / \mathrm{g} \\
2,86 \pm 0,11 \mathrm{ppm}\end{array}$ \\
\hline $\begin{array}{l}\text { Gruta do } \\
\text { Mimoso }\end{array}$ & $\begin{array}{l}\text { M1-1-Estalagmite corroída, presa no piso de } \\
\text { cascalho } \\
\text { M1-6- Fragmento de cone submerso } \\
\text { (quebrado) mais crosta que o reveste } \\
\text { M1-7- Fragmento de crosta que reveste a } \\
\text { parede }\end{array}$ & $\begin{array}{l}-18 m \\
-15 m\end{array}$ & $\begin{array}{c}\text { Fresco }=224 \pm 10 \mathrm{ng} / \mathrm{g} \\
2,24 \pm 0,1 \mathrm{ppm} \\
\begin{array}{c}\text { Alterado }=442 \pm 11 \\
\mathrm{ng} / \mathrm{g} \\
4,42 \pm 0,11 \mathrm{ppm} \\
51 \pm 11 \mathrm{ng} / \mathrm{g} \\
0,51 \pm 0,11 \mathrm{ppm} \\
78 \pm 11 \mathrm{ng} / \mathrm{g} \\
0,78 \pm 0,11 \mathrm{ppm}\end{array}\end{array}$ \\
\hline
\end{tabular}

*em $m$ em relação ao nivel do lago no dia da coleta. 
Foram datadas pelo método U/Th estalagmites coletadas a 11,3 m (MI-1) e 9,7 m de profundidade (MI-2), uma estalagmite e uma estalactite recoberta por crosta subaquática coletadas respectivamente a $9,3 \mathrm{~m}$ de profundidade (ML-9) e a 9,3 m de profundidade (MI-10). As amostras e as idades são apresentadas na Figura 6.13 e na Tabela 6.4. Deste conjunto somente as amostras Ml-1 A e B, MI-2A, MI-10B revelaram idades confiáveis (Tabela 6.4).

A presença de estalactites, cobertas por crostas subaquáticas em profundidades de até $16 \mathrm{~m}$ do nivel d'água sazonal mínimo, sugere um efeito tectônico na submersão destes espeleotemas, pois consideramos improvável uma variação muita grande para efeito meramente climático em uma região continental.

A influência climática aparece claramente na idade de cerca de 5000 anos BP das amostras datadas, coletadas a $8 \mathrm{~m}$ abaixo do nível mínimo atual. Esta idade é tida em diversas regiōes como um período seco, podendo ter ocasionado a descida do lago.

Porém a taxa média de subida do nível d'água calculada de $1,8 \mathrm{~mm} / \mathrm{ano}$ é considerada muito alta tanto para efeito exclusivamente climático ou tectônico. Assim, atribui-se esta alta taxa de subida do nivel d'água, como uma somatória dos dois fatores, sem quantificar a influência de cada fator, conforme será discutido no Capítulo 7. 


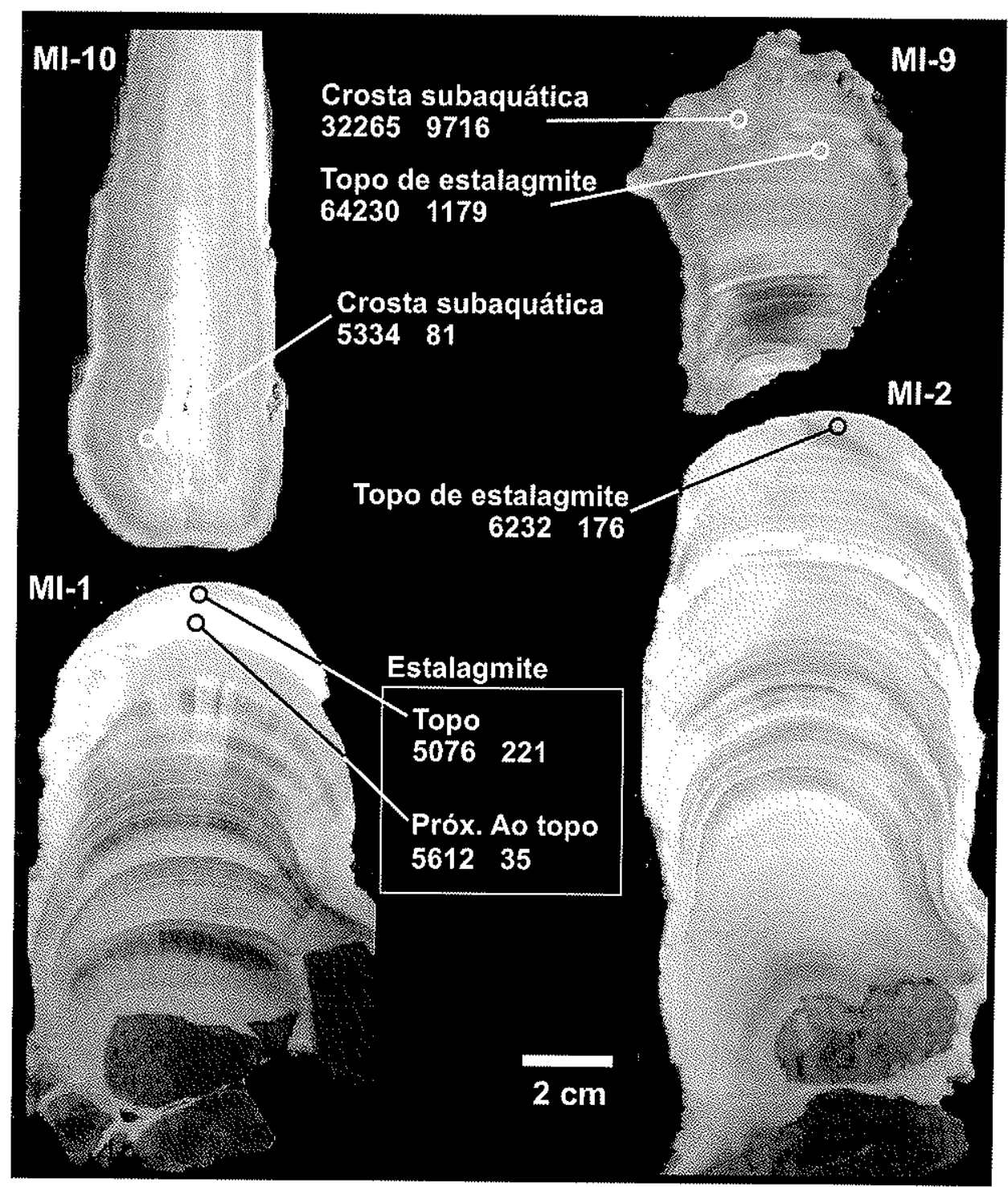

Figura 6.13: Espeleotemas da Gruta Mimoso, com as respectivas idades obtidas. 
Tabela 6.3: Idades obtidas para espeleotemas da Gruta Mimoso.

\begin{tabular}{|c|c|c|c|c|c|c|c|c|}
\hline Amostra & Prof. (m) & ${ }^{338} \cup(p p b)$ & ${ }^{232} \mathrm{Th}$ (ppt) & $\begin{array}{c}\delta^{234} \mathrm{U} \\
\text { measured }^{a}\end{array}$ & {$\left[_{(\mathrm{ppm})^{\mathrm{d}}}^{\left[^{230} \mathrm{Th}{ }^{232} \mathrm{Th}\right]}\right.$} & $\begin{array}{c}\text { Age } \\
\text { uncorrected }\end{array}$ & $\begin{array}{l}\text { Age } \\
\text { corrected }^{c, e}\end{array}$ & $\begin{array}{l}{ }^{234} U_{\text {iritial }} \\
\text { corrected }\end{array}$ \\
\hline \multicolumn{9}{|c|}{ Estalagmites submerses } \\
\hline$M !-1 A$ & 11,6 & $28,9 \pm 0,1$ & $375 \pm 11$ & $125,1 \pm 5,8$ & $69 \pm 3$ & $5412 \pm 144$ & $5076 \pm 221$ & $126,9 \pm 5,9$ \\
\hline MI-1B & 11,6 & $558,5 \pm 1,0$ & $780 \pm 8$ & $101,3 \pm 1,4$ & $657 \pm 7$ & $5649 \pm 30$ & $5612 \pm 35$ & $102,9 \pm 1,5$ \\
\hline$M !-2 A$ & 10 & $35,8 \pm 0,1$ & $258 \pm 13$ & $80,6 \pm 4,5$ & $141 \pm 8$ & $6427 \pm 147$ & $6232 \pm 176$ & $82,0 \pm 4,5$ \\
\hline MI-9B & 9 & $16,9 \pm 0,1$ & $488 \pm 13$ & $254,0 \geq 9,8$ & $327 \pm 9$ & $64875 \pm 1144$ & $6.230 \pm 1179$ & $304,6 \pm 11,8$ \\
\hline \multicolumn{9}{|c|}{ Crosias subaquáticas } \\
\hline MI-9A & 9 & $42,8 \pm 0,1$ & $53006 \pm 258$ & $1099,9 \pm 6,2$ & $11 \pm 0$ & $49714 \pm 1324$ & $32265 \pm 9716$ & $1204,9 \pm 32,5$ \\
\hline Ml-10B & 9 & $103,0 \pm 0,2$ & $1242 \pm 12$ & $1682,3 \pm 6,8$ & $180 \pm 2$ & $5463 \pm 50$ & $5334 \pm 81$ & $1707,9 \pm 6,9$ \\
\hline
\end{tabular}

Analytical errors are 20 of the mean.

${ }^{a}{ }^{234} U=\left(\left[{ }^{234} U / /^{238} U\right]_{\text {activity }}-1\right) \times 1000$.

${ }^{b_{8}}{ }^{234} U_{\text {initial }}$ corrected was calculated based on ${ }^{230} \mathrm{Th}$ age $(T)$, i.e., $0^{234} U_{\text {initial }}=\delta^{234} U_{\text {measured }} X e^{\lambda 234^{*} T}$, and $T$ is corrected age.

$\left.{ }^{c}{ }^{230} \mathrm{Th} /{ }^{238} \mathrm{U}\right]_{\text {activity }}=1-\mathrm{e}^{-\lambda .230 T}+\left(\hat{0}^{234} \mathrm{U}_{\text {measured }} / 1000\right)\left[\lambda_{230} /\left(\lambda_{230}-\lambda_{234}\right)\right]\left(1-\mathrm{e}^{-(\lambda 230-\lambda 234) T}\right)$, where $T$ is the age.

Decay constants are $9.1577 \times 10^{-6} \mathrm{yr}^{-1}$ for ${ }^{230} \mathrm{Th}, 2.8263 \times 10^{-6} \mathrm{yr}^{-1}$ for ${ }^{234} \mathrm{U}$, and $1.55125 \times 10^{-10} \mathrm{yr}^{-1}$ for ${ }^{238} \mathrm{U}$.

"The degree of detrital ${ }^{230} \mathrm{Th}$ contamination is indicated by the $\left[{ }^{230} \mathrm{Th} /{ }^{232} \mathrm{Th}\right.$ ] atomic ratio instead of the activity ratio.

${ }^{2}$ Age corrections were calculated using an average crustal ${ }^{230} \mathrm{Th} /{ }^{232} \mathrm{Th}$ atomic ratio of $4.4 \times 10^{-6} \pm 2.2 \times 10^{-6}$.

Those are the values for a material at secular equilibrium, with the crustal ${ }^{232} \mathrm{Th} /{ }^{238} \mathrm{U}$ value of 3.8 . The errors are arbitrarily assumed to be $50 \%$.

Tabela 6.4: Taxas de subida do nivel d'água na Gruta Mimoso.

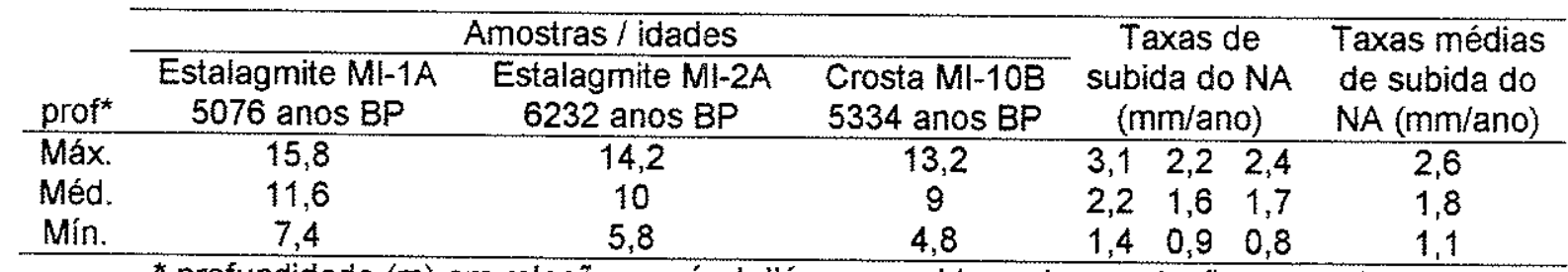

* profundidade $(m)$ em relação ao nível d'água considerando a variação sazonal. 


\subsection{Evidências geomorfológicas}

A principal evidência geomorfológica da existência de tectônica recente na Serra da Bodoquena é a presença de superfície de calcários do Planalto da Bodoquena soerguida em relação ao embasamento granito-gnáissico a oeste e aos dolomitos a leste (Figuras 6.1B e C), em parte demarcada por escarpas de erosão remontante (Figura 6.14). Esta configuração é interpretada aqui, como sendo produto de movimentação tectônica recente de blocos ao longo de falhamentos. Esta interpretação baseia-se no fato de que deveria ocorrer a situação contrária, ou seja, os calcários, com solubilidade muito maior do que os dolomitos e gnaisses deveriam estar rebaixados relativamente às rochas menos solúveis, se não houvesse um soerguimento tectônico da unidade mais solúvel ou uma subsidência tectônica das unidades menos solúveis.

A escarpa oeste (Figuras 4.3C, 4.10, 6.1 e 6.14A), que limita o planalto de calcários com o embasamento granito-gnáissico, possui caráter retilíneo (sinuosidade de 1,13 na escala de 1:50.000) segundo a direção $\mathrm{N}-\mathrm{S}$, com desniveis variando entre $240 \mathrm{e}$ $360 \mathrm{~m}$ (Figura 4.10). Em alguns trechos desta escarpa o bloco alto também é sustentado pelo embasamento (Anexo $5 b$, perfis $A-A^{\prime}, D^{\prime}-D^{\prime}$ ), mas dominantemente corresponde aos calcários. Do lado leste da serra o desnivel que marca o contato entre calcários e dolomitos é evidente nos setores norte e sul da serra, pois no setor central da serra ambas litologias encontram-se niveladas aproximadamente na cota $700 \mathrm{~m}$, o que é interpretado como sendo a superfície original pré-falhamentos (Figura 4.10, perfis 7697,25 e 7680,84, e Anexo 4). Na região sul este desnivel é marcado pela escarpa leste (Figuras 4.3, 4.10, 6.1 e 6.14B). Esta escarpa caracteriza-se por segmentos retilíneos alternados com trechos menores irregulares, o que é expresso pela variação de sinuosidade entre 1,07 e 2,6 em escala de 1:50.000. 


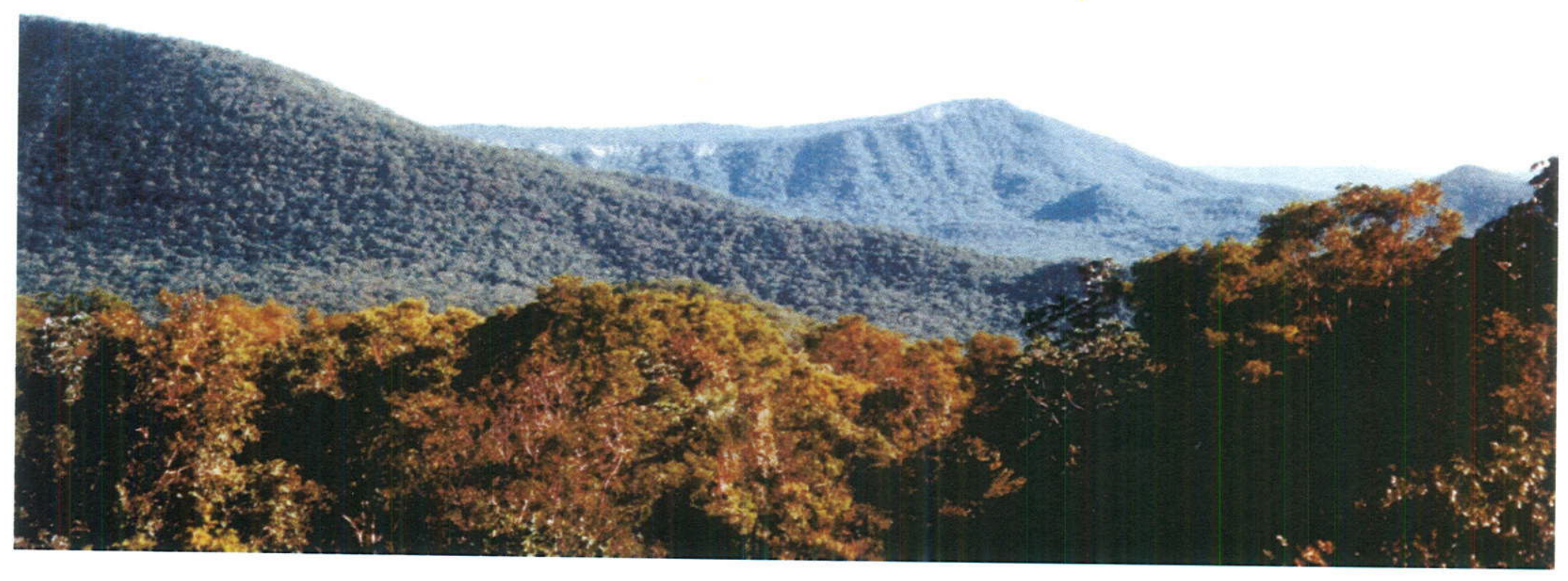

B

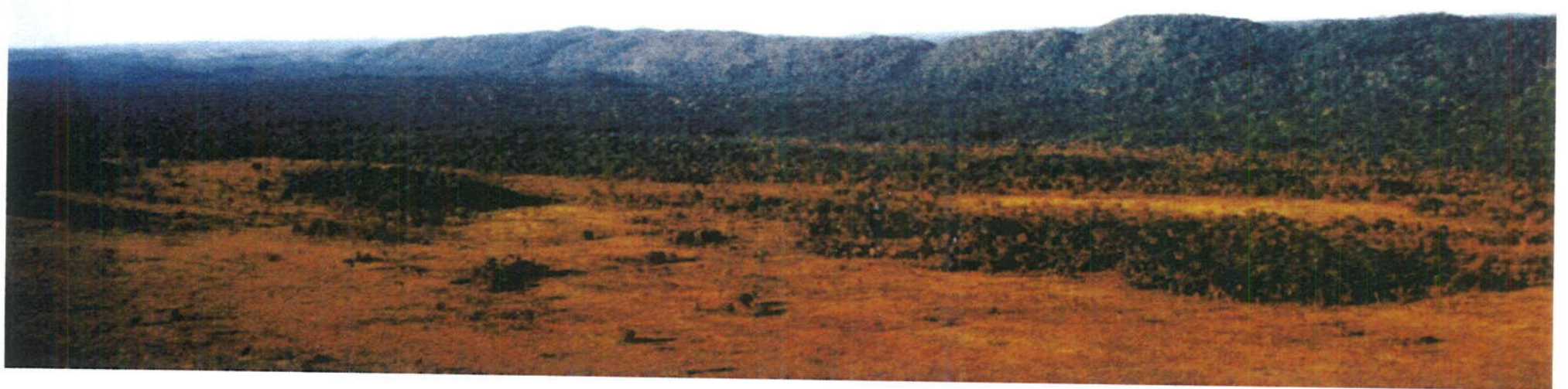

Figura 6.14: Vista aéreas das escarpas oeste (A) e leste (B). Fotos de Paulo C. Boggiani. 
Outro fato que demonstra a atuação da tectônica recente na região são as diferenças de relevo observadas entre os setores norte e sul da unidade CLCP no Planalto da Bodoquena, como já discutido no Capitulo 4.1.1. Observa-se que o setor norte (Área Rio Salobra) possui feições fluviais mais marcantes em relação as cársticas e com rios entalhados (canyons) (CLCP e CPA) (Figura 4.6A), enquanto o setor sul (Área Rio Salobra) tem feições cársticas mais freqüentes e poucas feições fluviais (CLCP) (Figuras 4.6B e C), compondo duas bacias hidrográficas distintas. Além disso, as feições cársticas da Unidade CLCP são diferentes entre o setor norte e sul. No setor norte (Rio Salobra) predominam depressões de maior amplitude com formas convexas do tipo cockpit karst enquanto que no setor sul (Rio Perdido) ocorrem cones cársticos com depressões de fundo plano (Capítulo 4.3.1). Esta morfologia distinta é atribuida a gradientes hidráulicos maiores no setor norte e menores no setor sul. Ainda no setor norte destaca-se o entalhamento do Rio Salobra (Unidade CPA) que alcança até $400 \mathrm{~m}$ de profundidade, assim como o seu afluente, o Córrego Serra, com até $300 \mathrm{~m}$, atingindo o substrato não carbonático (Capítulo 4.3.2). Visto que são formadas pela mesma rocha (calcário) com estruturas similares, o setor norte é mais entalhado devido a um maior soerguimento tectônico relativo, pois o bloco em subsidência, neste caso, é o próprio Pantanal. Um exemplo deste entalhamento acentuado do setor norte é a Gruta Urubu Rei (Capitulo 5.3.1.1), localizada na vertente sul do Córrego Serra, que é uma nascente cárstica perene do tipo vauclusiana suspensa à cerca de $150 \mathrm{~m}$ acima do nível do rio (Figuras 4.12A e E).

Através de um perfil norte-sul da Serra da Bodoquena, essencialmente na unidade CLCP, os índices de razão fundo/altura de vale (Keller \& Pinter, 1996) e gradiente hidráulico foram calculados para os rios Perdido e Salobra, evidenciando o maior entalhamento e o maior gradiente hidráulico na porção norte, conforme pode ser visto na Figura 6.15 e na Tabela 6.5. O Rio Salobra apresenta-se entalhado e com alto gradiente no seu alto é médio curso, até atingir o nível de base regional no seu baixo curso, onde se torna um rio amplo e de baixo gradiente, formando uma planície aluvial. Neste ponto os afluentes do Rio Salobra atingem o seu maior grau de entalhamento, como o Córrego Serra, mencionado acima, com o valor mais baixo de razão fundo/altura de vale, que é de 6. 
Tabela 6.5: Parâmetros morfométricos das bacias dos rios Perdido e Salobra.

\begin{tabular}{lcc} 
Total da bacia $\left(\mathrm{A}_{\mathrm{t}}\right)-\mathrm{km}^{2}$ & 707,84 & 1640,95 \\
Áreas do lado direito $\left(\mathrm{A}_{\mathrm{r}}\right)-\mathrm{km}^{2}$ & 411,51 & 427,83 \\
Índice de assimetria de drenagem $\left(\mathrm{A}_{\mathrm{f}}\right)$ & 58,14 & 26,07 \\
Gradiente médio & 0,02 & 0,01 \\
Vf médio & 38 & 15 \\
\hline
\end{tabular}

Observou-se uma tendência dos afluentes do Rio Salobra se concentrarem na porção oeste das bacias. Através do indice de assimetria de drenagem $\left(A_{f}\right)$ de 26,07 ficou clara esta tendência, com a maior parte dos seus afluentes no lado oeste da bacia, que indica soerguimento à oeste e subsidência a leste (Figura 6.15 e Tabela 6.5). Esta assimetria pode ser vista nos perfis da Figura 4.10. Já na bacia do Rio Perdido isto acontece apenas em alguns trechos com índice de assimetria de drenagem $\left(A_{f}\right)$ de 58,14 , indicando que a bacia está próxima à simetria.

Os cursos dos rios Salobra e Perdido seguem um alinhamento na direçäo nortesul, só que com fluxos em sentidos opostos. Posteriormente o Rio Salobra segue para leste, em direção ao Rio Miranda, seguindo a tendência geral dos rios da região. Por outro lado o Rio Perdido possui um comportamento anômalo. A partir da sua nascente na superfície mais elevada (Unidade CLCP), desenvolve-se no sentido E-SE por cerca de 16 quilômetros. Chegando nas proximidades da escarpa leste, muda abruptamente seu curso no sentido SW (Figura 4.3). Esta mudança de rumo é inesperada, pois o gradiente hidráulico maior seria no rumo E-SE, em direção ao nível de base mais próximo, representado pelo rio Miranda. Este desvio do seu curso para SW é atribuido à presença de uma estrutura desruptiva regional NE-SW (Figura 6.1), que cruza o setor sul da serra, onde o bloco SE estaria suavemente alçado em relação ao bloco NW, desta forma gerando uma barreira para a drenagem do Rio Perdido, o que acabou desviando este no sentido SW, onde segue esta feição regional em direção ao Rio Apa. 

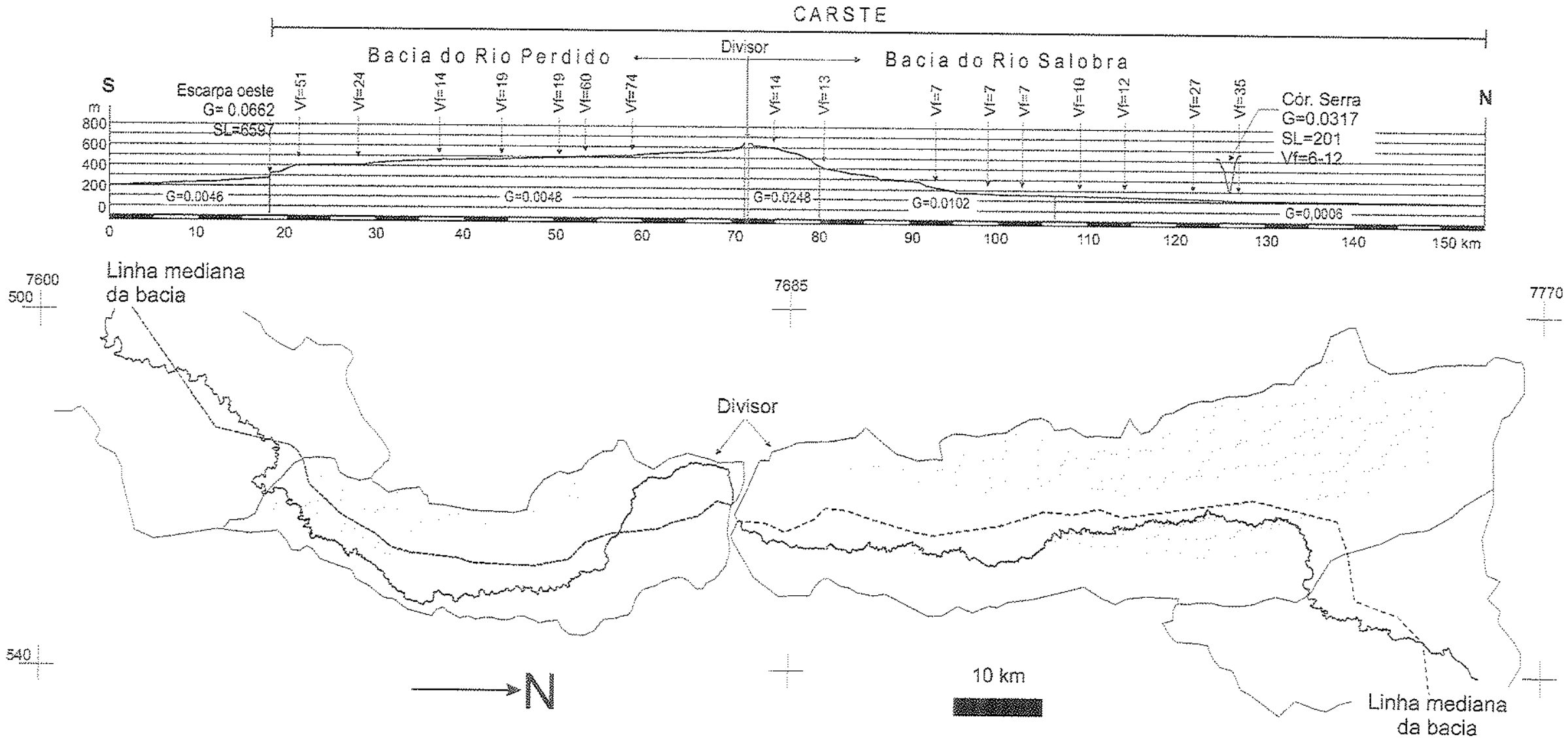

Figura 6.15: Perfis longitudinais e mapa das bacias dos rios Salobra e Perdido, com gradiente hidráulico (G) por setor e razão fundoaltura de vale (Vf) de alguns pontos. 


\section{DISCUSSÃO}

\subsection{Compartimentação e evolução do relevo cárstico}

A Serra da Bodoquena esteve durante parte do Paleozóico coberta por sedimentos devonianos da Bacia do Paraná, fato evidenciado por isópacas dos grupos Rio Ivaí (Assine et al., 1998) e Paraná (Assine, informação verbal; Milani \& Ramos, 1998).

Antes da deposiçăo da Formação Aquidauana houve a erosão das unidades mais antigas da Bacia do Paraná e de parte do substrato composto de rochas précambrianas. Este substrato incluiu os calcários do Grupo Corumbá que nesta fase tiveram feições de epicarste e condutos freáticos rasos removidos.

No Permo-Carbonifero o Arco de Assunção inicia sua atividade e a Serra da Bodoquena deveria estar em soerguimento neste período (Assine, informação verbal). Durante a deposição da Formação Aquidauana no Carbonifero o Arco de Assunção atuava como uma área elevada conforme indicado por paleocorrentes (Gesicki, 1996). Isópacas mostram que a Formação Aquidauana recobriu a Serra da Bodoquena no Carbonífero (Milani e Ramos, 1998).

Durante o Mesozóico houve deposição na Bacia do Paraná, mas não se sabe se estes depósitos recobriram a Serra da Bodoquena.

O desenvolvimento do aqǘfero cárstico da Serra da Bodoquena deve ter se iniciado, em ambiente interestratal, com o soerguimento associado à remoção da Formação Aquidauana que precedeu a Bacia do Pantanal. Este soerguimento regional pré-Pantanal provavelmente se iniciou no final do Cretáceo/Mioceno (Assine \& Soares, 2004; Ussami et al., 1999). Baseados em geofísica, Shiraiwa \& Ussami (1993) estimaram que no início da orogenia andina a área do Pantanal Matogrossense foi soerguida a cerca de 960 metros, seguida de subsidência, e atualmente as áreas elevadas (600-800 metros) ao redor da bacia, como os planaltos da Bodoquena, Maracaju-Campo Grande e da Provincia Serrana, representam a topografia erodida deste período. Alvarenga et al. (1982) atribuem também uma idade pós-cretácica no Planalto de Maracaju-Campo grande, devido à quase total ausência de sedimentos cretáceos neste local.

Hoje se observa uma superficie de aplainamento que nivela a Serra da Bodoquena e o Planalto de Maracaju-Campo Grande que representa o final deste soerguimento préPantanal. Esta superfície de aplainamento mais elevada, que marca o Planalto da Bodoquena, pode ser relacionada com a Superfície Sul-americana nesta região (Soares e Landim, 1976; Ross, 1991). Uma superficie correlata foi observada na Serra das 
Araras, a norte, por Ross (1991) atribuídas a um periodo pré-cretáceo. Ross (1991) ainda atribui uma fase de soerguimento durante o cretáceo.

Esta superficie original está presente na Serra da Bodoquena especialmente na porção central da serra e nos alinhamentos dos topos dos morros em outras áreas, com altitude de 730 metros.

Assim pode-se inferir que o início do desenvolvimento de sistemas cársticos da Serra da Bodoquena ocorreu no Terciário, concomitantemente com o soerguimento, erosão das coberturas paleozóicas e desenvolvimento da superfície de aplainamento Sul-americana. É possível que a iniciação e desenvolvimento freático profundo das cavernas ocorreu sob a cobertura arenitica da Formaçăo Aquidauana, como ainda ocorre na porção sudeste da serra (PAD).

Com o entalhamento da Superfície Sul-Americana durante o Terciário ocorre ampliação da zona vadosa o que aliado à exposição das rochas carbonáticas, permite o desenvolvimento do epicarste, inicialmente em uma condição apenas de planalto, pois a Bacia do Pantanal estava em seu inicio. A associação de dois grupos de rochas carbonáticas, calcários e dolomitos, gerou dois compartimentos com características morfológicas do relevo e das cavernas as unidades CLCP e PCMR.

$\mathrm{Na}$ área dos calcários a oeste, partindo da superficie aplainada original, desenvolve-se o carste labiríntico da Unidade CLCP que reflete uma condição de aplainamento extremo com remoção de solo e coberturas gerando uma superfície rochosa exposta à ação das águas meteóricas (carste exposto). O padrão de fraturamento subvertical representa a principal descontinuidade que condiciona a instalação das fendas de dissolução. A grande quantidade de fraturas subverticias permeáveis em uma superfície aplainada sem solo, sob ação direta das águas meteóricas gera o carste labirintico. Nesta situação há uma infiltração difusa ao longo dos planos de fraturas, sem concentração da injeção em pontos especificos. Esta paisagem evolui, a partir desta superfície carbonática aplainada inicial, em fendas alargadas, e quando sua base alcança o nivel de base local, estas fendas se transformam em corredores, por erosão lateral, mantendo a injeção difusa. Com o rebaixamento do nivel d'água, alguns setores do carste labiríntico foram substituidos por carste poligonal devido à geração de pontos de injeção nas intersecções de fraturas, seguindo conexões com o aqüifero de condutos. Os blocos altos separados por fendas, corredores e pontos de absorção começam a desenvolver morfologia de cones. Progressivamente as fendas de dissolução, os corredores cársticos e o carste poligonal 
tendem a se transformarem em planícies a medida que o entalhamento vertical atinge o nivel d'água, gerando morros residuais da Unidade PCMR-C.

O relevo na área dos calcários no planalto evoluiu de forma diferenciada devido ao soerguimento relativo distinto, que gerou gradientes hidráulicos maiores no setor norte em comparaçăo ao setor sul. O relevo do setor sul permaneceu com a morfologia original de carste labirintico e carste poligonal por apresentar baixo gradiente hidráulico (nivel d'água raso). Já o setor norte possui uma drenagem fluvial mais desenvolvida, com rios entalhados, devido a um maior gradiente hidráulico, restando apenas carste labirintico e carste poligonal nos interflúvios. O carste poligonal neste setor onde há maior gradiente e aqüiferos de condutos mais desenvolvidos é composto de formas convexas tipo cockpit karst, com depressões de maior amplitude.

Esta diferenciação do relevo entre os blocos norte e sul do Planalto da Bodoquena deve ter sido gerada a partir da formação da Bacia do Pantanal, que gerou desnivel e conseqüentemente maior gradiente hidráulico.

O inicio da sedimentação da Bacia do Pantanal é atribuído ao Plio-Pleistoceno (Assine \& Soares, 2004; Ussami et al., 1999).

$\mathrm{Na}$ área dos dolomitos (setor leste da serra), partindo da superfície aplainada original, desenvolveram-se planicies com morros residuais. Nesta área poderia ter havido uma cobertura arenitica no periodo de início de carstificação. Antes da subsidencia do Pantanal a superficie dolomitica estava nivelada com a dos calcários. Atualmente a superficie original nos dolomitos é pouco preservada, ocorrendo na parte central da serra e em raros topos de morros. Solo espesso cobrindo o epicarste é uma característica marcante desta área. Atualmente se observa que onde os dolomitos estão em situação de planalto, ocorrem poucos morros residuais. Assim os morros devem ter se formado através do entalhamento da superfície original e expansão das planícies, com o modelamento da topografia na Depressão do Rio Miranda após o início da subsidência do Pantanal. Deste modo a partir da mesma superfície original o relevo nos dolomitos evoluiu diferentemente dos calcários, para um relevo de morros e serras, que progressivamente desenvolveu planícies com cobertura de solo. Os morros residuais da Unidade PCMR são resultado do excesso de impurezas (veios de quartzo) e são delineados em planta e perfil pela estrutura da rocha. O relevo desenvolvido nos dolomitos da Unidade PCMR tem, portanto, influência da litologia. A natureza dolomitica das rochas não permitiu o desenvolvimento de muitas feições cársticas de superfície, apesar do desenvolvimento local de condutos e cavernas. 


\subsection{Cavernas e espeleogênese}

Através do estudo da morfologia de cavernas a espeleogênese foi interpretada individualmente em cada grupo de cavernas no Capítulo 5. Porém alguns processos podem ser generalizados para todo o sistema cárstico.

Uma das características que predominam nas cavernas da Serra da Bodoquena é a presença de redes anastomosadas. Estas redes marcam a fase de iniciação e desenvolvimento freático em várias cavernas especialmente nos calcários. $O$ baixo gradiente hidráulico na fase de iniciação permitiu o desenvolvimento de redes anastomosadas. No setor dos calcários o rebaixamento do nivel d'água gerou entalhamento vadoso das redes anastomosadas, em condutos hidraulicamente mais eficientes, geralmente situados nas partes inferiores dos planos de anastomose. Estas cavernas possuem evidências de uma fase de preenchimento sedimentar em alguns locais com ampliações paragenéticos e cúpulas. Não se sabe se este processo se estendeu por toda a região, pois ocorre apenas em algumas cavernas.

Nos dolomitos as feições freáticas foram obliteradas pelo abatimento, mas acredita-se que estas redes anastomosadas possam ter existido na fase de iniciação. Porém nos dolomitos interpreta-se que a iniciação e o desenvolvimento freático tenha ocorrido parcialmente em ambiente de carste interestratal. Esta interpretação deve-se à comparação com os padrões de cavernas que existem na Fazenda Santa Maria (Unidade $P A D$ ) onde os arenitos recobrem parte da área, expondo grandes volumes de cavernas freáticas com o gradativo recuo dos arenitos da Formação Aquidauana.

A existência de um padrão recorrente de salōes de abatimento nos dolomitos é interpretada como influência da litologia. A pequena quantidade de cavernas, porém com maior volume, demonstra que o desenvolvimento de condutos cársticos nos dolomitos é concentrado em fraturas, falhas ou camadas mais permeáveis, não sendo bem desenvolvido na maioria dos locais, mas de grande volume quando presente. Evidências de campo mostram que dolomitos dissolvem mais lentamente, seu aqǘfero possui poucos condutos e cavernas maiores, com poucas formas de relevo cárstico em superfície (Rauch \& White, 1977) e em alguns casos dolomitos possuem pouco ou nenhum desenvolvimento de cavernas (Klimchouck \& Ford, 2000). White (1984) apud Ford \& Williams (1989) sugere que a menor taxa de dissolução dos dolomitos permite uma corrosão lenta e uniforme que alcança extensões maiores ao longo do aqüifero. Por outro lado os calcários com taxa de dissolução maior perdem rapidamente a capacidade de dissolução ampliando muito os condutos ao longo de pequenas extensões. 
Após uma fase de iniciação e desenvolvimento freático (iniciada no Terciário) as cavernas no setor dolomítico, sofreram uma exposição subaérea parcial, evidenciada por estalagmites e outros espeleotemas vadosos atualmente abaixo do nivel d'água. Esta fase de exposição subaérea é atribuida a um soerguimento regional ocorrido antes da instalação da Bacia do Pantanal. Acompanhando a evolução da Bacia do Pantanal ocorre um escalonamento da superfície original na Serra da Bodoquena através do movimento de blocos em soerguimento e subsidência relativos. Neste quadro atribui-se a submersão dos espeleotemas vadosos, acima citados, ao evento de subsidência relativa do bloco leste (dolomítico). Estes salōes apresentam atualmente grandes volumes, mostrando que o aqüifero cárstico é bem desenvolvido em profundidade, fato corroborado por dados de vazão de poços da região.

$\mathrm{Na}$ Unidade PCMR observou-se que na Área de Bodoquena as cavernas desenvolvidas em calcários possuem espesso preenchimento sedimentar, às vezes preenchendo totalmente os condutos. Este preenchimento mais efetivo nesta área é interpretado como efeito da situação topográfica rebaixada destas cavernas (abaixo de $300 \mathrm{~m}$ ), próximas da planicie aluvial do baixo Rio Salobra que é o nivel de base local. Assim estas cavernas foram abertas em situação topográfica distinta e posteriormente por razões de subsidência tectônica, a subida do nível d'água causou o assoreamento destes condutos.

\subsection{Tectónica recente}

A subsidência tectônica do Pantanal é um fato reconhecido desde os trabalhos de Almeida (1945), que também relacionou sua origem a orogenia andina (Almeida \& Lima, 1959). Trabalhos mais recentes mostram que o surgimento da Bacia do Pantanal é reflexo de esforços distensionais no arco flexural da bacia de antepais do Chaco, alcançando até 500 metros de espessura de sedimentos (Shiraiwa, 1994; Ussami et al., 1999). O desenvolvimento desta bacia faz com que haja uma subsidência não só no depocentro, mas também por todas as bordas e áreas adjacentes. Desta forma é lógico pensar que a Serra da Bodoquena, que está na borda sul da Bacia do Pantanal, esteja em subsidência. Na porção norte da serra as rochas do Grupo Corumbá (inclusive os calcários) encontram-se sob os sedimentos quaternários da Bacia do Pantanal, que recobre também toda a Faixa Paraguai, aflorando novamente em morros testemunhos no interior da bacia e definitivamente na Serra das Araras, em Mato Grosso (Figura 2.2). Além desta subsidência regional, outro efeito da tectônica recente da Bacia do Pantanal é o rebaixamento do nivel de base, pois as altitudes no Pantanal chegam poucos metros 
no seu interior, alcançando rapidamente a quase 1000 metros nas suas bordas, causando assim uma convergência das drenagens para seu interior, e um maior gradiente hidráulico nas bordas.

Assim o papel da tectônica recente na área é muito expressivo na configuração regional do relevo visto o rebaixamento da Depressão do Rio Miranda em relação ao Planalto da Bodoquena. A existência de escarpas retilineas separando os dois blocos, com possiveis capturas de drenagem no Rio Perdido reforçam esta idéia.

Como já descrito anteriormente, atualmente há um desnivel entre os calcários e os dolomitos. Se a superficie original era a mesma para as duas rochas, como ocorre na porção central da serra, seria de se esperar que os dolomitos formassem relevo de morros com cotas mais elevadas que os calcários, porém com as planícies niveladas entre si. Diversos estudos laboratoriais demonstram que a calcita é mais solúvel que a dolomita (Chou et al., 1989; Appelo \& Postma, 1993) da mesma forma que os calcários em relação aos dolomitos (Rauch \& White, 1977). Além da quantidade de magnésio, outros fatores que aumentam a solubilidade é uma menor granulação e uma menor quantidade de impurezas (Rauch \& White, 1977). Os dolomitos da área possuem em geral granulação grossa retardando ainda mais a carstificação.

Se os calcários são mais solúveis pode-se inferir que o desnível em relação aos dolomitos era ainda maior do que a situação atual, pois a denudação rebaixou a topografia nos calcários de forma mais intensa do que nos dolomitos.

Assim a abertura do pantanal gerou desniveis entre blocos distintos, hoje delimitados por escarpas. As falhas que delimitam os blocos em soerguimento e subsidência não foram observadas diretamente, mas dados geofísicos confirmam sua existência. A origem tectônica da escarpa oeste já havia sido levantada por Almeida (1965) e mencionada por Kohler et al. (1998). Por outro lado, Alvarenga et al. (1982) sugerem que não é possivel afirmar tratar-se de uma escarpa de falha, pois não há evidências para tal. Interpreta-se que estes desniveis a oeste e a leste tenham sido causados por movimentações recentes de falhas de componente principal normal, com geração de escarpas atualmente modificadas pela erosão remontante. Os trechos mais sinuosos das escarpas correspondem ao entalhamento da escarpa de calcários pela erosão remontante.

Ussami et al. (1999) delimitaram pelo menos duas falhas na borda oeste da Bacia do Pantanal, que podem ser relacionadas com algumas estruturas da Serra da Bodoquena. Segundo Ussami et al. (1999) estas falhas são normais e de direção NS/NNW-SSE com mergulho para leste, e são reativações de antigas falhas de empurrão 
proterozóicas/cambrianas de vergência para oeste. Pode-se notar que uma das falhas delimitadas por Ussami et al. (1999) corresponde aproximadamente à escarpa oeste do Planalto da Bodoquena. Observando os perfis gravimétricos de Ussami et al. (1999) também se observa que o bloco que corresponde a Serra da Bodoquena é uma anomalia positiva, enquanto à oeste, a escarpa é marcada por uma anomalia negativa, que marca a falha.

No bloco mais rebaixado de dolomitos encontram-se grandes salöes de abatimento, reflexo do tipo litológico, mas a existência de espeleotemas vadosos submersos, em alguns deles, é atribuido ao rebaixamento tectônico. Neste caso, provavelmente, temos influência climática e tectônica no processo de afogamento das cavernas e espeleotemas vadosos. Não foi possivel até o momento estabelecer o peso de cada um dos fatores. Mas através da quantificação da variação atual do nivel da água (NA) vimos que na Gruta Mimoso a variação atual é 10 metros e desta forma em uma época muito seca seria possivel que as estalagmites mais profundas datadas estivessem em ambiente vadoso. O período de coleta foi mais seco (pluviosidade de $912,8 \mathrm{~mm}$ anuais em 2002) que a média de $1419 \mathrm{~mm}$ anuais (obtida para 24 anos de registro), porém não foi o mais seco já registrado na região (581,3 mm anuais em 1999). A quantidade de chuva em 2002 foi muito menor que o máximo de $1954 \mathrm{~mm}$ anuais registrado em 1991.

A influência climática pode ser avaliada a partir de dados paleoclimáticos. Apesar de não serem de regiôes próximas, parece que é consenso que houve um periodo mais seco que o atual na maior parte do Brasil, a exceção da regiảo Nordeste. Ledru (1993) determinou um período seco entre 5500 e 4500 anos BP, no Brasil Central, e indica que este período seco ocorreu em toda a América do Sul em épocas distintas, de acordo com a latitude. Na região Amazônica brasileira e na Venezuela e Colômbia, um período seco entre 8000 e 4000 anos é observado (Ledru, 1993).Thomas \& Thorp (1995) fazem uma estimativa da pluviosidade nos trópicos mostrando que a partir de 9000 anos BP inicia-se uma fase seca que culmina a 3500 anos BP, quando se inicia uma fase úmida chegando aos niveis atuais. Ainda no Brasil Central Salgado-Laboriau et al. (1997) descrevem clima seco entre 18500 e 6500 anos BP, com um aumento de umidade por volta dos 5000 anos BP. Ledru et al. (1998) estudando diversas localidades nas regiões Sudeste e Central do Brasil observaram clima seco entre 10000 e 7000 anos BP, sazonal ente 7000 e 4000 anos BP e próximo das condições atuais após 4000 anos BP. Em terraços do Rio Paraná, no estado do Paraná, Stevaux (2000) reconhece um período seco entre $>40000$ e 8000 anos $\mathrm{BP}$, seguido de período úmido que durou até 
3500 anos BP. Parolin \& Stevaux (2001), descrevem no Rio Paraná no estado do Mato Grosso do Sul, depósitos eólicos indicativos de clima seco entre 10000 e 3000 anos BP.

Dados de locais mais próximos säo contraditórios. De um lado mostram um período de clima úmido entre 10200 e 5190 anos BP que teria permitido a individualização de lagos no Pantanal Matogrossense (Bezerra, 1999). Assine \& Soares (2004) estabeleceram o limite Pleistoceno/Holoceno para o estabelecimento das terras úmidas no Pantanal Matogrossense. Por outro lado indícios de clima seco entre 4572 e 11420 anos BP foram verificados no Pantanal Matogrossense por Victoria et al. (1995).

As idades obtidas neste trabalho mostram que o lago esteve mais baixo entre no mínimo 23000 (idade calculada) e 5300 anos BP quando houve deposição de espeleotemas vadosos, assim indicando um clima mais seco, porém não árido visto a deposição de espeleotemas. Este periodo não coincide totalmente com períodos secos relacionados em outros trabalhos. A partir de 5300 anos $\mathrm{BP}$ há deposição de crostas em ambiente subaquático, com o nível do lago mais alto, assim o clima era úmido, talvez muito parecido com o atual.

O papel da subsidência tectônica no afogamento dos espeleotemas vadosos é indicada pela rapidez de subida do nível d’água. Auler \& Smart (2001) registraram uma descida do nivel d'água de 13 metros durante os últimos 17000 anos BP no Nordeste do Brasil, que possuía um clima úmido passando para condições semi-áridas nos dias de hoje. A partir destes dados obteve-se taxas de descida do nível d'água de cerca de 0,76 $\mathrm{mm} / \mathrm{ano}$ nesta região. Apesar de ser em um local muito distante, este valor é uma referência para quantificação da variação do nivel d'água no Brasil através de fenômenos climáticos, pois esta região encontra-se em uma área cratônica estável. As taxas de subida do nivel d'água obtidas na Gruta Mimoso são de 8 metros em 5000 anos, ou seja, 1,8 mm/ano, que é cerca de 2 vezes mais rápido que no Nordeste. Além disso, atualmente no Nordeste o clima é semi-árido com precipitações em torno de 500 $\mathrm{mm}$ anuais, não ocorrendo precipitação de espeleotemas, diferente das condições climáticas da Serra da Bodoquena. Se antes de 5300 anos BP o clima da Serra da Bodoquena fosse semi-árido a tal ponto de baixar o nível do lago em cerca de 12 metros não deveria haver a deposição de estalagmites e estalactites com taxas de crescimento de aproximadamente 0,003 mm/ano, como acontece no Nordeste do Brasil. Assim mesmo, na fase seca, houve a deposição de espeleotemas, porém com o lago mais baixo. A subida do lago ocorre mais continuamente por subsidência tectônica, e portanto, estaria também ocorrendo durante a fase seca. Em 5000 anos BP teria se iniciado uma conjunção de condições climáticas úmidas e subsidência tectônica que 
teriam causado a submersão dos espeleotemas vadosos com alta taxa de subida do nível d'água. Após 5000 anos $\mathrm{BP}$ fases secas săo registradas em carbonatos precipitados em lagoas no Pantanal em 3820 anos BP (Assine et al., 1997) e em estalagmites na Gruta João Arruda (próxima a Gruta Mimoso) entre 3800 e 2500 anos BP (Bertaux et al., 2002). Estes eventos aparentemente não afetaram o lago da Gruta Mimoso, visto que a deposição de crosta subaquática, que se iniciou em 5000 anos BP, é constante até hoje, não apresentando hiatos deposicionais.

Uma subsidência maior no bloco leste também é evidenciada pela assimetria das bacias dos rios Salobra e Perdido, no planalto, com a maior parte dos seus afluentes a oeste.

As diferenças entre os setores norte e sul do planalto (Unidade CLCP), como canyons e formas côncavas de carste poligonal no bloco norte, devem-se ao um soerguimento relativo e a um aumento do gradiente hidráulico. A posiçăo elevada da nascente da Gruta Urubu-Rei é o melhor exemplo deste alto entalhamento fluvial, pois uma nascente suspensa em relação ao fundo do vale fluvial demonstra que no setor norte a taxa de entalhamento fluvial é maior do que a taxa de entalhamento vadoso dos condutos cársticos da nascente em conseqüência. Este soerguimento relativo do setor norte é relacionado às áreas rebaixadas do Pantanal Matogrossense, que se encontram em subsidência. Em contraste ao setor norte, os poucos vales fluviais do setor sul apresentam baixo entalhamento e vales abertos.

No setor sul algumas mudanças de curso marcam o Rio Perdido. Em relaçăo a primeira mudança de curso que ocorre junto à escarpa leste, não foi possivel precisar se ela teria sido causada por uma captura de drenagem ou por razões hidrogeológicas. Neste caso o problema em afirmar de que se trata de uma captura reside no fato de que capturas geralmente ocorrem quando a escarpa de falha no bloco alto barra o curso de um rio, o desviando. Neste local o Rio Perdido está sobre o bloco alto, assim não estaria sendo barrado devido a escarpa. Já a sua segunda mudança de curso acredita-se que seja uma captura de drenagem associada a estrutura linear, provavelmente uma falha, relacionada a borda da Bacia do Pantanal. O Rio Perdido segue seu curso sobre esta estrutura até atingir o Rio Apa. 


\section{CONCLUSÕES}

Como principal conclusão desta pesquisa propõe-se um modelo da evolução do carste da Serra da Bodoquena associando as principais fases evolutivas a uma cronologia relativa (Figura 8.1):

Fase 1

1- As unidades pré-cambrianas da Serra da Bodoquena sofreram erosão durante o Carbonífero e posteriormente foram cobertas pelos sedimentos da Formação Aquidauna. Possiveis feições epicársticas e feições freáticas rasas do précarbonifera foram removidas durante a sedimentação glacial da Formação Aquidauana.

Fase II

2- Do Cretáceo até o Terciário o soerguimento pré-Bacia do Pantanal ocasiona a progressiva remoção da cobertura arenítica.

3- Inicia-se a geração da superfície de aplainamento no final do Cretáceo, correlacionada regionalmente a Superficie Sul-Americana.

4- Iniciação e desenvolvimento freático dos condutos cársticos que provavelmente ocorreu tanto em condição de recarga livre na parte oeste (rochas carbonáticas expostas) como também em condição de carste interestratal na parte leste (rochas carbonáticas cobertas pela Formação Aquidauana).

Fase III

5- Em condição de relativa estabilidade tectônica, a maior parte da cobertura arenítica é removida, instalando-se a Superfície Sul-americana, que regionalmente é relacionada com o Planalto de Maracaju-Campo Grande e localmente foi denominada de Superfície Bodoquena. Está superficie hoje é vista já erodida no Planalto da Bodoquena, nivelando rochas do embasamento granitognáissico, metassedimentos do Grupo Corumbá e os arenitos da Formação Aquidauana. Interpreta-se que neste estágio calcários e dolomitos encontravamse nivelados.

Fase IV

6- Início de soerguimento e entalhamento da Superficie Sul-Americana através de sistemas fluviais. 
7- $O$ entaihamento gera a ampliação da zona vadosa acompanhada do desenvolvimento de formas do epicarste. Inicia-se o carste labiríntico a partir da superficie aplainada nos calcários. Nos dolomitos diferenciam-se planícies cársticas de cristas e morros residuais.

8- Continuidade do desenvolvimento dos condutos em rede anastomosada e condutos ascendentes nos dolomitos.

9- O rebaixamento do nivel d'água devido ao soerguimento lento inicia um entalhamento vadoso nas cavernas, que nos dolomitos evolui para salões de abatimento. Na zona vadosa inicia-se a deposição de espeleotemas subaéreos.

10- Desenvolve-se carste interestratal nas rochas carbonáticas recobertas pelos arenitos.

\section{Fase $\mathrm{V}$}

11- A instalação da Bacia do Pantanal no Terciário interrompe a faixa de rochas proterozóicas, individualizando o bloco norte da Serra das Araras e o bloco sul da Serra da Bodoquena.

12- Através da instalação da Bacia do Pantanal surgem ao longo da Serra da Bodoquena setores em subsidência relativamente a outros em soerguimento, ocasionando o aumento do gradiente hidráulico nos blocos soerguidos

13- Através da movimentação relativa entre blocos, provavelmente ao longo de falhas de movimentação normal dominante a superficie original é escalonada em três compartimentos topográficos demarcados através de escarpas. Os blocos do embasamento a oeste e de dolomitos a leste são rebaixados relativamente a um bloco central de calcários.

14- Na Unidade CLCP o carste labirintico é substituido em alguns setores para carste poligonal onde há desenvolvimento de pontos de absorção na intersecção de fraturas subverticais. As fendas são ampliadas através do fluxo de recarga ao longo de fraturas verticais. Quando este entalhamento atinge o nivel de base ocorre o alargamento formando os corredores cársticos.

15- Acompanhando a ampliação da zona vadosa, parte dos condutos freáticos são expostos ou sofrem entalhamento vadoso em sua base. Com a progressiva evolução dos cones cársticos e ampliaçăo das planícies condutos são expostos nas vertentes dos cones ocorrendo atualmente como cavernas reliquiares.

16- Grande parte da infiltração autogênica da Unidade CLCP ressurge através de nascentes que se instalam junto a escarpa leste do planalto no limite com a 
Unidade PCMR iniciando a alimentar uma rede de drenagem superficial nas planicies cársticas. O Rio Perdido passa a ter trechos subterrâneos em conseqüência de ampliação da porosidade secundária nos calcários acompanhada de aumento de gradiente hidráulico.

17- $\mathrm{Na}$ Unidade PCMR as cristas dolomíticas tornam-se morros residuais individualizados por drenagens oriundas das nascentes da escarpa leste. Nos morros preservam-se trechos de condutos ascendentes, como salőes de abatimento, em parte alagados pela subida do nivel d’água causada pela subsidência. Formam-se lagos onde espeleotemas vadosos são submersos e espeleotemas subaquáticos são depositados. Variações climáticas durante o Quaternário geram uma oscilação do nivel d'água.

18-Na Unidade CLCP - Área Rio Salobra, em soerguimento relativo, instalam-se vales fluviais e a drenagem subterrânea é drenada para eles. Se desenvolvem canyons na Unidade CPA acompanhando grande parte da drenagem fluvial. Condutos freáticos são expostos acima do nivel de base local (Gruta Urubu-Rei), denotando o grande entalhamento fluvial. Carste labiríntico e carste poligonal (cockpit karst) são preservados nos interflúvios.

19- Na Unidade PAD o processo de dolinamento é intensificado acompanhando a ampliação dos condutos freáticos. 


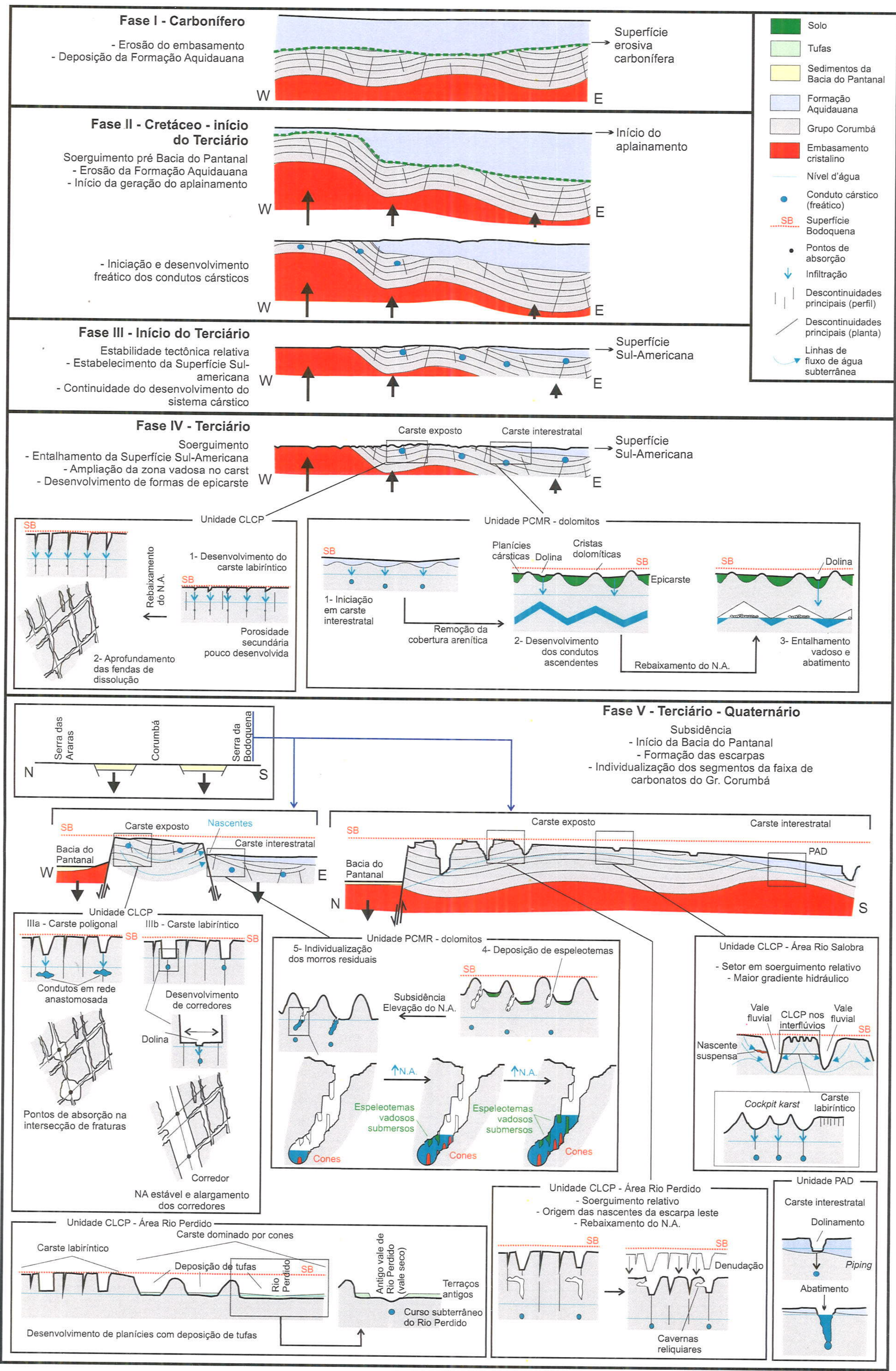

Figura 8.1: Modelo evolutivo do carste da Serra da Bodoquena. 


\section{REFERÊNCIAS BIBLIOGRÁFICAS}

ALMEIDA, F. F. M. de (1945) Geologia do sudoeste mato-grossense. Boletim da Divisão de Geologia e Mineralogia, DNPM, Rio de Janeiro, v. 116, 118 p.

ALMEIDA, F. F. M. de (1965) Geologia da Serra da Bodoquena (Mato Grosso), Brasil. Boletim da Divisão de Geologia e Mineralogia, DNPM, Rio de Janeiro, v. 219, p. 196.

ALMEIDA, F. F. M. de \& LIMA, M.A. (1959) Planalto Centro-Ocidental e Pantanal Matogrossense. In: CONGRESSO INTERNACIONAL DE GEOGRAFIA, 18, Rio de Janeiro, 1956. Guia de excursão. Rio de Janeiro, UGI, n. 1, 169 p.

ALMEIDA, F.F.M. de; HASUI, Y.; BRITO NEVES, B.B. de (1976) The Upper Precambrian of South America. Boletim IG, Instituto de Geociências-USP, São Paulo, v. 7, p. 45-80.

ALVARENGA, C.J.S. (1988) Turbiditos e a glaciação do final do Proterozóico Superior no cinturão Paraguai, Mato Grosso. Revista Brasileira de Geociéncias, v. 18, n. 3 , p. 323-327.

ALVARENGA, C.J.S. \& TROMPETTE, R. (1992) Glacially influenced sedimentation in the Later Proterozoic of the Paraguay Belt (Mato Grosso, Brazil). Palaeogeography, Palaeoclimatology, Palaeoecology, v. 92, p. 85-105.

ALVARENGA, C.J.S. \& TROMPETTE, R. (1993) Evolução tectônica brasiliana da Faixa Paraguai: a estruturação da regiâo de Cuiabá. Revista Brasileira de Geociências, v. 23, n. 1, p. $18-30$.

ALVARENGA, C.J.S. \& TROMPETTE, R. (1994) A Faixa Paraguai e sua compartimentação estratigráfica e tectônica. In: CONGRESSO BRASILEIRO DE GEOLOGIA, 38., Camburiú, 1994. Anais, Camburiú, SBG, p. 239-240.

ALVARENGA, S.M.; BRASIL, A.E.; DEL'ARCO, D.M. (1982) Geomorfologia. In: Projeto RADAMBRASIL. Folha SF-21 Campo Grande. Rio de Janeiro, MME. p. 125-184. (Levantamento de Recursos Naturais, 28).

APPELO, C.A.J. \& POSTMA, D. (1993) Geochemistry, groundwater and pollution. Rotterdam, USA, A.A. Balkema. p. 86-141.

ARAUUJO, H.J.T. de; SANTOS NETO, A. dos; TRINDADE, C.A.H.; PINTO, J.C. de A.; MONTALVÃO, R.M.G. de; DOURADO, T.D. de C.; PALMEIRA, R.C. de B.; TASSINARI, C.C.G. (1982) Geologia. In: Projeto RADAMBRASIL. Folha SF-21 Campo Grande. Rio de Janeiro, MME. p. 9 -124. (Levantamento de Recursos Naturais, 28).

ASSINE, M. L. \& SOARES, P. C. (2004) Quaternary of the Pantanal, west-central Brazil. Quaternary International, v. 114, p. 23-34.

ASSINE, M.L., SOARES, P.C., ANGULO, R.J. (1997) Construção e abandono de lobos na evolução do leque do rio Taquari, Pantanal Mato-grossense. In: CONGRESSO DA ASSOCIAÇÃO BRASILEIRA DE ESTUDOS DO QUATERNÁRIO, 6., Curitiba, Resumos, Curitiba, ABEQUA, p. 431-433.

ASSINE, M.L.; PERINOTTO, J.A.J.; ALVARENGA, C.J.S.; PETRI, S. (1998) Arquitetura estratigráfica, tratos deposicionais e paleogeografia da Bacia do Paraná (Brasil) no Neo-Ordoviciano/Eo-Siluriano. Revista Brasileira de Geociennicas, v. 28, n.1, p. 61 76. 
ATKINSON, T.C.; HARMON, R.S.; SMART, P.L.; WALTHAM, A.C. (1978) Palaeoclimate and geomorphic implications of ${ }^{230} \mathrm{Th} /{ }^{234} \mathrm{U}$ dates on speleothems from Britain. Nature, v. 272, p. 24-28.

AULER, A. (1991) Mergulhando nas Águas Cristalinas do Mato Grosso do Sul. O Carste, v. 3, n. 8, p. $47-49$.

AULER, A. (1992) Expedição Franco-Brasileira "Bonito'92". O Carste, v. 4, n. 12, p. 8187.

AULER, A. \& BOLLER, A. (1992) A Expedição Franco-Brasileira Bonito'92. O Carste, vol. 4, v. 11, p. 77-78.

AULER, A. \& SMART, P.L. (2001) Late Quaternary paleoclimate in semiarid Northeastern Brazil from U-series dating of travertine and water-table speleothems. Quaternary research, v. 55, p. 159-167.

AULER, A.; RUBBIOLI, E.L.; BRANTI, R. (2001a) As grandes cavernas do Brasil. Belo Horizonte, Grupo Bambui de Pesquisas Espeleológicas. $227 \mathrm{p}$.

AULER, A.; MOURA, V.M.; LOTT, C.F.; RUBBIOLI, E.L.; ALT, L. DE R.; PIRES, L.J.; DAVID, H. (2001b). Relatórios de geologia e geomorfologia regionais, geologia local, hidrogeologia, meteorologia, topografia e fotografia. Belo Horizonte, Grupo Bambui de Pesquisas Espeleológicas. 57 p. (Relatório para o Licenciamento Ambiental do Abismo Anhumas).

AYUB, S.; SALLUN FILHO, W.; FERREIRA, N.B.; ABREU, A.E.S. DE; TEIXEIRA, L.G.P.; ELEUTÉRIO, T.S.H. (1996). Caracterização geo-espeleológica preliminar das cavernas da porçáo central da Serra da Bodoquena, na região de Bonito, MS. São Paulo, GGEO. 51 p., 11 anexos. (Relatório Técnico para a Prefeitura do Municipio de Bonito - MS)

BAKER, A. \& PROCTOR, C. (2000) Actively growing subaueous stalagmites. Cave and Karst Science, v. 27, n. 2, p. 79-83.

BERTAUX, J., SONDAG, F., SANTOS, R., SOUBIES, F., CAUSSE, C., PLAGNES, V., Le CORNEC, F., SEIDEL, A. (2002) Paleoclimatic record of speleothems in a tropical region: study of laminated sequences from a Holocene stalagmite in central-west Brazil. Quaternary International, v. 89, p. 3-16.

BEZERRA, M.A.O. (1999) O Uso de Multi-traçadores na Reconstrução do Holoceno no Pantanal Mato-grossense, Corumbá, MS. São Carlos, 214 p. Tese (Doutorado) Universidade Federal de São Carlos.

BOGGIANI, P.C. (1998) Análise Estratigráfica da Bacia Corumbá (Neoproterozóico) Mato Grosso do Sul. São Paulo, 181 p. Tese (Doutorado) - Instituto de Geociências, Universidade de São Paulo.

BOGGIANI, P.C. \& COIMBRA, A.M. (1995) Quaternary limestones of the Pantanal Area, Brazil. Anais da Academia Brasileira de Ciencias, v. 67, n. 3, p. 343-349.

BOGGIANI, P. C., ATENCIO, D., KARMANN, I. (1986) Carbonatos Secundários da Gruta do Lago Azul (Bonito, MS): Nesquehonita, Hidromagnesita, Aragonita e Calcita. In: CONGRESSO BRASILEIRO DE GEOLOGIA, 39., Goiânia, Resumos e Breves Comunicações, Goiânia, SBG, v.1, p. 177-178.

BOGGIANI, P.C.; FAIRCHILD, T.R.; COIMBRA, A.C. (1993) O Grupo Corumbá (Neoproterozóico-Cambriano) na região central da Serra da Bodoquena (Faixa Paraguai), Mato Grosso do Sul. Revista Brasileira de Geociências, v. 23, n. 3, p. 301-305. 
BOGGIANI, P. C., COIMBRA, A. M., GESICKI, A. L. D., SIAL, A. N., FERREIRA, V. P., RIBEIRO, F. B., FLEXOR, J. M. (2002) Tufas Calcárias da Serra da Bodoquena, MS: cachoeiras petrificadas ao longo dos rios. in: SCHOBBENHAUS, C.; CAMPOS, D.A.; QUEIROZ, E.T.; WINGE, M.; BERBERT-BORN, M. eds. Sítios Geológicos e Paleontológicos do Brasil. Brasília-DF, DNPM, p. 249-259.

BROOK, G.A. \& FORD, D.C. (1978) The origin of labyrinth and tower karst and the climatic conditions necessary for their development. Nature, v. 275, p. 493-496.

BURROUGH, P.A. \& McDONNELL, R.A. (2000) Principles of geographical information systems. New York, Oxford University. $333 p$.

CHAVEZ JR., P.S.; SIDES, S.C.; ANDERSON, J.A. (1991) Comparison of three different methods to merge multiresolution and multispectral data: Landsat TM and SPOT Panchromatic. Photogrammetric Engineering \& Remote Sensing, v. 57, n. 3, p. 295 $-303$.

CHOU, L.; GARRELS, R.M.; WOLLAST, R. (1989) Comparative study of the kinetics and mechanisms of dissolution of carbonate minerals. Chemical geology, v. 78, p. 269282.

CORDANI, U.G.; THOMAZ-FILHO, A.; BRITO-NEVES, B.B.; KAWASHITA, K. (1985) On the applicability of the $\mathrm{Rb}-\mathrm{Sr}$ method to argillaceous sedimentary rocks: some examples from Precambrian sequences of Brazil. Giornale di Geologia, s. 3, v. 47, n. 1-2, p. 253-280.

CRÓSTA, A.P. (1993) Processamento digital de imagens de sensoriamento remoto. Campinas, UNICAMP. 170p.

FAIRCHILD, T.R.; SALLUN FILHO, W.; SALLUN, A.E.M.; BOGGIANI, P.C.; HIDALGO, R.L.L. (1999) Revisão da biota fóssil do Grupo Corumbá (MS), limite Neoproterozóico-Cambriano. In: CONGRESSO BRASILEIRO DE PALEONTOLOGIA, 16, Crato, Resumos, Crato, SBP, p. 42.

FORD, D. (1996) Dating cave deposits. Climate change: the karst record. Karst Waters Institute, p. 30-31 (Special Publication, 2).

FORD, D. \& WILLIAMS, P. (1989) Karst Geomorphology and Hydrology. London, UK, Chapman \& Hall. $601 \mathrm{p}$.

FORD, D.; LAURITZEN, S.-E; WORTHINGTON, S. (2000) Speleogenesis of Castleguard Cave, Rocky Mountains, Alberta, Canada. In: KLIMCHOUK A.; FORD D.; PALMER A.; DREYBRODT, W., eds. Speleogenesis: Evolution of Karst Aquifers. Huntsville, USA, National Speleological Society. p. 332-337.

FORD, T.D. \& PEDLEY, H.M. (1996) A review of tufa and travertine deposits of the world. Earth Science Reviews, v. 41, p. 117-175.

GASCOYNE, M. (1992) Palaeoclimate determination from cave calcite deposits. Quaternary Science Reviews, v. 11, p. 609-632.

GESICKI, A.L. (1996) Geologia da Formação Aquidauana (Neopaleozóico, Bacia do Paraná) na porção centro-norte do Estado de Mato Grosso do Sul. São Paulo, 126 p. Dissertação (Mestrado) - Instituto de Geociências, Universidade de São Paulo.

GESICKI, A.L. \& RICCOMINI, C. (1998) Neotectônica na borda sudeste do Pantanal Matogrossense. In: CONGRESSO BRASILEIRO DE GEOLOGIA, 40., Belo Horizonte, Anais, Belo Horizonte, SBG, p. 84. 
GNASPINI, P., TRAJANO, E., SÁNCHEZ L. E. (1994) Província Espeleológica da Serra da Bodoquena, MS: Exploração, Topografia e Biologia. Espeleo-Tema, v. 17, n. 1944.

GODOI, H. de O. (2001) Folha SF.21-X-A Aquidauana. Goiânia, CPRM, Programa Levantamentos Geológicos Básicos do Brasil.

GODOI, H. de O. \& MARTINS, E.G. (1999) Folha SF.21 Campo Grande. Goiânia, CPRM, Programa Levantamentos Geológicos Básicos do Brasil.

GODOY, N. M. (1986) Nota Sobre a Fauna Cavernicola de Bonito, MS. Espeleo-Tema, v. 15, p. $80-92$.

HILL, C.A. \& FORTI, P. (1997) Cave minerals of the world. Huntsville, USA, National Speleological Society. $463 \mathrm{p}$.

HOBSON, R.D. (1972) Surface roughness in topography: quantitative approach. In: CHORLEY, R.J. ed. Spatial analysis in geomorphology. New York, USA, Harper \& Row, p. $222-245$.

IBGE (2002) Atlas Geográfico Escolar. Rio de Janeiro, IBGE. 200 p.

IMPERIO, L. \& PEZZOLATO, P. (1991) Brasile'90. Non solo samba. Speleologia, v. 25, p. 58-73.

KARMANN, I. \& SÁNCHEZ, L. E. (1979) Distribuição das rochas carbonáticas e províncias espeleológicas do Brasil. Espeleo-Tema, v. 13, n. 105-164.

KARMANN, I. \& SÁNCHEZ, L. E. (1986) Speleological Provinces in Brazil. In: CONGRESSO INTERNACIONAL DE ESPELEOLOGIA, 9., Barcelona, Resumos, Barcelona, Union International D'espeleologie, v.1, p.151-153.

KAUFMAN, A.; WASSERBURG, G.J.; PORCELLI, D.; BAR-MATTHEWS, M.; AYALON, A.; HALICZ, L. (1998) U-Th isotope systematics from the Soreq cave, Israel and climatic correlations. Earth and Planetary Science Letters, v. 156, p. 141-155.

KELLER, E.A. \& PINTER, N. (1996) Active tectonics - Earthquakes, Uplift, and Landscape. New Jersey, USA, Prentice Hall. $338 \mathrm{p}$.

KLIMCHOUCK, A. \& FORD, D. (2000) Lithologic and structural controls of dissolutional cave development. In: KLIMCHOUCK, A.; FORD, D.; PALMER, A.N.; DREYBRODT, W., eds. Speleogenesis: evolution of karst aquifers. Huntsville, USA, National Speleological Society. p. 54-64.

KOHLER, H. C.; AULER, A; CATTANIO, M.B. (1998) The subtropical karst of Bonito, western Brazil. In: DAOXIAN, Y. \& ZAIHUA, L., eds. Global Karst Correlation. Beijing, Science Press and VSP BV. p. 257-267.

LAURITZEN, S.-E. \& LUNDBERG J. (2000) Solutional and erosional morphology. In: KLIMCHOUCK, A.; FORD, D.; PALMER, A.N.; DREYBRODT, $W$., eds. Speleogenesis: evolution of karst aquifers. Huntsville, USA, National Speleological Society. p. 408-436.

LEDRU, M.P. (1993) Late Quaternary enviromental and climatic changes in Central Brazil. Quaternary Research, v. 39, p. 90-98.

LEDRU, M.P.; SALGADO LABOURIAU, M.L.; LORSCHEITTER, M.L. (1998) Vegetation dynamics in southern and central Brazil during the last $10,000 \mathrm{yr}$ B.P. Review of Palaeobotany and Palynology, v. 99, p. 131-142. 
LEIGHTON, M.W. \& PENDEXTER, C. (1962). Carbonate rock types. In: HAM, W.E., ed. Classification of carbonate rocks. Tulsa, USA, Am. Ass. of Petroleum Geologists, $p$. 33-61.

LI, W.X.; LUNDBERG, J.; DICKIN, A.P.; FORD, D.C.; SCHWARCZ, H.P.; MCNUTT, R.; WLLIAMS, D. (1989) High-precision mass-spectrometric uranium-series dating of cave deposits and implications for palaeoclimate studies. Nature, v. 339, p. 534536.

LINO, C. F.; BOGGIANI, P. C.; CORTESÃO, J.; GODOY, N. M.; KARMANN, I. (1984) Projeto Grutas de Bonito (MS) - Diretrizes para um Plano de Manejo Turístico. Săo Paulo, 212 p. (Relatório apresentado à MS-TUR, SPHAN e FNPM)

LUDWIG, K.R.; SIMMONS, K.R.; SZABO, B.J.; WINOGRAD, I.J.; LANDWEHR, J.M.; RIGGS, A.C.; HOFFMAN, R.J. (1992) Mass-spectrometric ${ }^{230} \mathrm{Th}^{234} \mathrm{U}^{238} \mathrm{U}$ dating of the Devils Hole calcite vein. Science, v. 258, p. 284-287.

LUNAS, J.R. da S. (2000) Turismo Sustentável - Descrição e Avaliação da Gestão do Turismo de Bonito-MS., Brasilia, 105 p. Dissertação (Mestrado), Universidade de Brasilia.

MARTINET, B. \& SOUGY, J. (1961) Utilisation pratique des classications chimiques des roches carbonatées. Annales de la facultá dês sciences de l'Université de Dakar, v. 6. p. 81-92.

MENDES, J. C. (1957) Grutas Calcárias na Serra da Bodoquena, Mato Grosso. Boletim Paulista de Geografia, v. 5, p. 70-77.

MILANI, E.J. \& RAMOS, V.A. 1998. Orogenias paleozóicas no domínio sul-ocidental do Gondwana e os cilcos de subsidência da Bacia do Paraná. Revista Brasileira de Geociências, v. 28, n. 4, p. 473-484.

NETO, C.; CORREIA FILHO, F.C.L.; SCISLEWSKI,G.; CORREAA, J.C..; CAVALLON, L.A.; CERQUEIRA, N.L.S.; NOGUEIRA, V.L. (1976) Projeto Bodoquena.Goiânia, DNPM/CPRM.

NIMER, E. (1979) Um modelo metodológico de classificação de climas. Revista Brasileira de Geografia, v. 41, p. 59-89.

NOGUEIRA, V.L. \& OLIVEIRA, C.C. (1978) Projeto Bonito-Aquidauana.Goiânia, DNPM/CPRM (Relatório ${ }^{\circ}$ 2744).

PALMER, A. N. (2000) Hydrogeologic control of cave patterns. In: KLIMCHOUCK, A.; FORD, D.; PALMER, A.N.; DREYBRODT, W., eds. Speleogenesis: evolution of karst aquifers. Huntsville, USA, National Speleological Society. p. 77-90.

PARIZEK, R.R. (1976) On the nature and significance of fracture traces and lineaments in carbonate and other terranes. In: YEVJEVUCH, V. Karst hydrology and water resources. Colorado, USA, Water Research Publicatons. p. 47-62.

PAROLIN, M. \& STEVAUX, J.C. (2001) Formação de Dunas Eólicas Durante o Holoceno Médio Taquaruçu, Mato Grosso do Sul. Pesquisas em Geocienncias, v. 28, n. 2, p. 43-46.

PEUKER, T.K.; FOWLER, R.J.; LITTLE, J.J.; MARK, D.M. (1978) The triangulated irregular network. In: AMERICAN CONGRESS ON SURVEY AND MAPPING PROC. OF THE DTM SYMPOSIUM, 5., St. Louis, 1978. Proceedings, Falls Church, ASF, p. 24 - 31.

PROJETO RADAMBRASIL (1982) Folha SF. 21 Campo Grande. Rio de Janeiro, MME. (Levantamento de Recursos Naturais, 28). 
RAUCH, H.W. \& WHITE, W.B. (1977) Dissolution kinetics of carbonate rocks. 1. Effects of lithology on dissolution rate. Water Resources Research, v. 13, p. 381-394.

RIBEIRO, F.B.; ROQUE, A.; BOGGIANI, P.C.; FLEXOR, J.M. (2001) Uranium and thorium series desequilibrium in quaternary carbonate deposits from the Serra da Bodoquena and Pantanal do Miranda, Mato Grosso do Sul State, central Brazil. Applied Radiation and Isotopes, v. 54, p. 153-173.

RICCOMINI, C. \& ASSUMPÇÃO, M. (1999) Quaternary tectonics in Brazil. Episodes, v. 22, n. 3, p. 221-225.

ROSELLO, M:; SAINT-ANDRÉ, P. A., AULER, A., DUSZ, J. F., GRENET, P., LABOUTIQUE, B. (1992) Plonger dans la Prehistoire Bresilienne. 55p (inédito).

ROSS, J.L.S. (1991) O contexto geotectônico e a morfogênese da Província Serrana de Mato Grosso. Revista /G, v. 12, n. 1/2, p. 21-37.

ROSS, J.L.S. (2000) Fundamentos da geografia da natureza. In: ROSS, J.L.S., ed. Geografia do Brasil. São Paulo, EDUSP. p. 13-65.

SALGADO-LABOURIAU, M.L.; CASSETI , V.; FERRAZ-VICENTINI, K.R.; MARTIN , L.; SOUBIĖS, F.; SUGUIO, K.; TURCQ, B. (1997) Late Quatemary vegetational and climatic changes in cerrado and palm swamp from Central Brazil. Palaeogeography, Palaeoclimatology, Palaeoecology, v. 128, p. 215-226.

SALLES, L.O.; GUEDES, P.G.; CARTELLE, C.; TOLEDO, P.M.; LIBERTINO, A.; CARVALHO, G.; FRACASSO, M.P.; GARBOGGINI, H.; CABRALI, P.; RUSSO, C.A.M. (2003) Quaternary mammals from na underwater cave in Serra da Bodoquena (Brazil). In: LATINAMERICAN CONGRESS OF SEDIMENTOLOGY, 3. Belém, Abstracts, Belém,UFPA, p. 216-218.

SALLUN FILHO, W.; KARMANN, I:; BOGGIANI, P.C. (2004) Paisagens cársticas da Serra da Bodoquena (MS). In: MANTESSO NETO, $V$.; BARTORELLI, A.; CARNEIRO, C.D.R.; BRITO NEVES, B.B., eds. Geologia do continente SulAmericano: Evolução da Obra de Femando Flávio Marques de Almeida. São Paulo, Beca. p. 424-433.

SHEN, C.C.; EDWARDS, R.L.; CHENG, H.; DORALE, J.A.; THOMAS, R.B.; MORAN, S.B.; WEINSTEIN, S.E.; EDMONDS, H.N. (2002) Uranium and thorium isotopic and concentration measurements by magnetic sector inductively coupled plasma mass spectrometry. Chemical Geology, v. 185, p. 165-178.

SHIRAIWA, S. (1994) Flexura da litosfera continental sob os Andes centrais e a origem da Bacia do Pantanal. São Paulo, 86 p. Tese (Doutorado), Instituto Astronómico e Geofísico, Universidade de São Paulo.

SHIRAIWA, S. \& USSAMI, N. (1993) Lithospheric flexure of the Central Andes and the origin of the Cenozoic Pantanal Basin, western Brazil. Washington, Fall Meeting American Geophysical Union, EOS Transactions American Geophysical Union, p. 500.

SOARES, P.C. \& LANDIM, P.M.B. (1976) Depósitos cenozóicos na região centro-sul do Brasil. Not. Geomorfol., vol. 16, n. 31, p. 17-39.

SRTM (2003) Shuttle Radar Topographic Mission. Disponivel na Internet para download via WMW. URL: http://strm.usgs.gov. Arquivo capturado em 10 de outubro de 2003. 
STEVAUX, J.C. (2000). Climatic events during the Late Pleistocene and Holocene in the Upper Parana River: Correlation with NE Argentina and South-Central Brazil. Quaternary International, v. 72, p. 73-85.

THOMAS, M.F. \& THORP, M.B. (1995). Geomorphic response to rapid climatic and hydrologic change during the Last Pleistocene and Early Holocene in the humid and sub-humid tropics. Quaternary Science Reviews, v. 14, p. 193-207.

USSAMI, N.; SHIRAIWA, S.; DOMINGUEZ, J.M.L. (1999). Basement reactivation in a sub-Andean foreland flexural bulge: the Pantanal wetland, SW Brazil. Tectonics, v. 18 , n. 1, p. 25-39.

VICTORIA, R.L.; FERNANDES, F.; MARTINELLI, L.A.; PICCOLO, M. de C.; CAMARGO, P.B. de; TRUMBORE, S. 1995. Past vegetation changes in the brazilian Pantanal arboreal-grassy savanna ecotone by using carbon isotopes in the soil organic matter. Global Change Biology, v. 1, p. 165-171.

WHITE, W.B. (1988) Geomorphology and hydrology of karst terrains. New York, USA, Oxford University Press, $464 \mathrm{p}$.

ZAINE, M.F. (1991) Análise dos fósseis de parte da Faixa Paraguai (MS, MT) e seu contexto temporal e paleoambiental. São Paulo, $218 \mathrm{p}$. Tese (Doutorado), Instituto de Geociências, Universidade de São Paulo.

ZAINE, M.F. \& FAIRCHILD, T.R. (1987) Novas considerações sobre os fósseis da Formação Tamengo, Grupo Corumbá, SW Brasil. In: CONGRESSO BRASILEIRO DE PALEONTOLOGIA, 10, Rio de Janeiro, Anais, Rio de Janeiro, SBP, v. 2, p. 797-807. 


\section{ANEXOS}

Anexo 1: Capítulo de livro -

SALLUN FILHO, W.; KARMANN, 1.; BOGGIANI, P.C. 2004. Paisagens cársticas da Serra da Bodoquena (MS). In: MANTESSO NETO, V.; BARTORELLI, A.; CARNEIRO, C.D.R.; BRITO NEVES, B.B. (EDS.) Geologia do continente Sul-Americano: evoluçăo da obra de Fernando Flávio Marques de Almeida. São Paulo, Beca. p. 424-433. 
William Sallun filho Instituto de Genciências, Universidade de Săo Paulo, Săo Paulo, SP wsallun@usp.br

Ivo Karmann Instituto de Geociências, Universidade de São Paulo, Sx̆o Paulo, SP ikarmann(d)usp.br

Paulo César Boggiani Instituto de Geociêneias, Universidade de Săo Paulo, São Paulo, SP boggiani(g) usp.br

Resumo:

A Serra da Bodoquena constitui um planalto carbonátim co desenvolvido nas rochas do Grupo Corumbá (Faixa Paraguai), que se ressalta topograficamente das planicies do Estado do Mato Grosso do Sul. Foi investigada pela primeira vez, do ponto de vista geologico e geomorfologico por Almeida (1965). Este autor notou que as condições da região eram favoráveis para carstificą̧ão, mas a incidência de feições cársticas por ele notada foi considerada baixa, ao contrário do que estudos mais especificos tèm revelado desde então.

O carste da Serra da Bodoquena possui três compartimentos de relevo principais. O Planalto da Bodoquena é sustentado por calcários calcíticos, com um carste autogênico com pavimentos cársticos e carste poligonal dominado por cones na porção sul e sistemas fluviais com rios entalhados e menos influência de um sistema cárstico, na porção norte. A Depressão do Rio Miranda composta principalmente de calcários dolomiticos com morros residuais e dolinas, associadas a amplas planicies cársticas e feições vadosas de cavernas atualmente abaixo do NA (espeleotemas submersos). O extremo sul da Serra da Bodoquena apresenta um carste interestratal, evidenciado por dolinas desenvolvidas nos arenitos da Formação Aquidauana da Bacia do Paraná.

Quanto às cavernas observam-se très padroes principais: 1) salöes de abatimentos irregulares em planta, formando planos inclinados em seção longitudinal; 2) cavernas em rede anastomosada em planta, com condutos circulares a elipticos e ramificą̧ões anastomosadas em seção transversal; 3) cavernas meandrantes em planta, por vezes associados a sumidouros ativos ou fósseis, com recarga alogênica na maioria dos casos.

A existència de tectomica recente na Serra da Bodoquena é sustentada pela sua proximidade com a Bacia do Pantanal e. por algumas feições como: espeleotemas subaéreos submer. sos; planalto sustentado por calcários calcíticos e planicies por calcários dolomiticos; escarpas delimitando o planalto; porção norte do planalto com rios mais entalhados que o sul; possive is capturas de drenagem do Rio Perdido e uma estrutura linear, aparentemente relacionada ao Pantanal, que cruza a Serra da Bodoquena.

Palavras-chave: Geologia, Geoespeleologia, Carste, Geomorfologia, Cavernas, Serra da Bodoquena.

Abstract:

The Serra da Bodoquena comprises a carbonate plateau developed upon rocks of the Corumbá Group (Paraguai Belt), that stands above the broad, rolling plains of the State of Mato Grosso do Sul (central-western Brazil). It was first investigated from a geological and geomorphological standpoint by Almeida (1965). This author" noted that the region's conditions favored karstification but he noted very few karstic features, contrary to what more recent detailed studies have revealed. 
The Bodoquena plateau is supported by calcitic limestones, with an autogenic karst presenting limestone pavements and poligonal karst with karst cones in the south and fluvial systems with entrenched rivers and less evidence of karstic influence in the north. The Rio Miranda Depression has developed mainly upon dolomitic limestones and presents residual hills and dolines associated with broad karstic plains and vadose cave features presently below the groundwater level (submerged speleothems). The extreme southern Serra da Bodoquena exhibits interstratal karst as indicated by dolines in sandstones of the Aquidauana Formation which discordantly overlies the Corumbá Group.

As for the caverns, three principal patterns are observed: 1) breakdown chambers irregular in planview and presenting inclined planes in longitudinal section; 2) anastomosing caves in plan-view and cross-section with circular to elliptical conduits; 3) and meandering caves in plan-view, some associated with active or fossil sinks, with allogenic recharge in the majority of cases.

That the region has been affected by recent tectonism is supported by its proximity to the Pantanal basin and by the following observations: speleothems formed subaerially are now submerged; the plateau is sustained by calcitic limestones and the plains by dolomitic limestones; the plateau is delimited by scarps; rivers are more entrenched in the northern plateau than in the south; possible stream capture is evident along the Rio Perdido; and a linear structure apparently related to the border of the Pantanal cuts the Serra da Bodoquena.

Keywords: Geology, Geospeleology,

Karst, Geomorphology, Caves, Serra da Bodoquena.

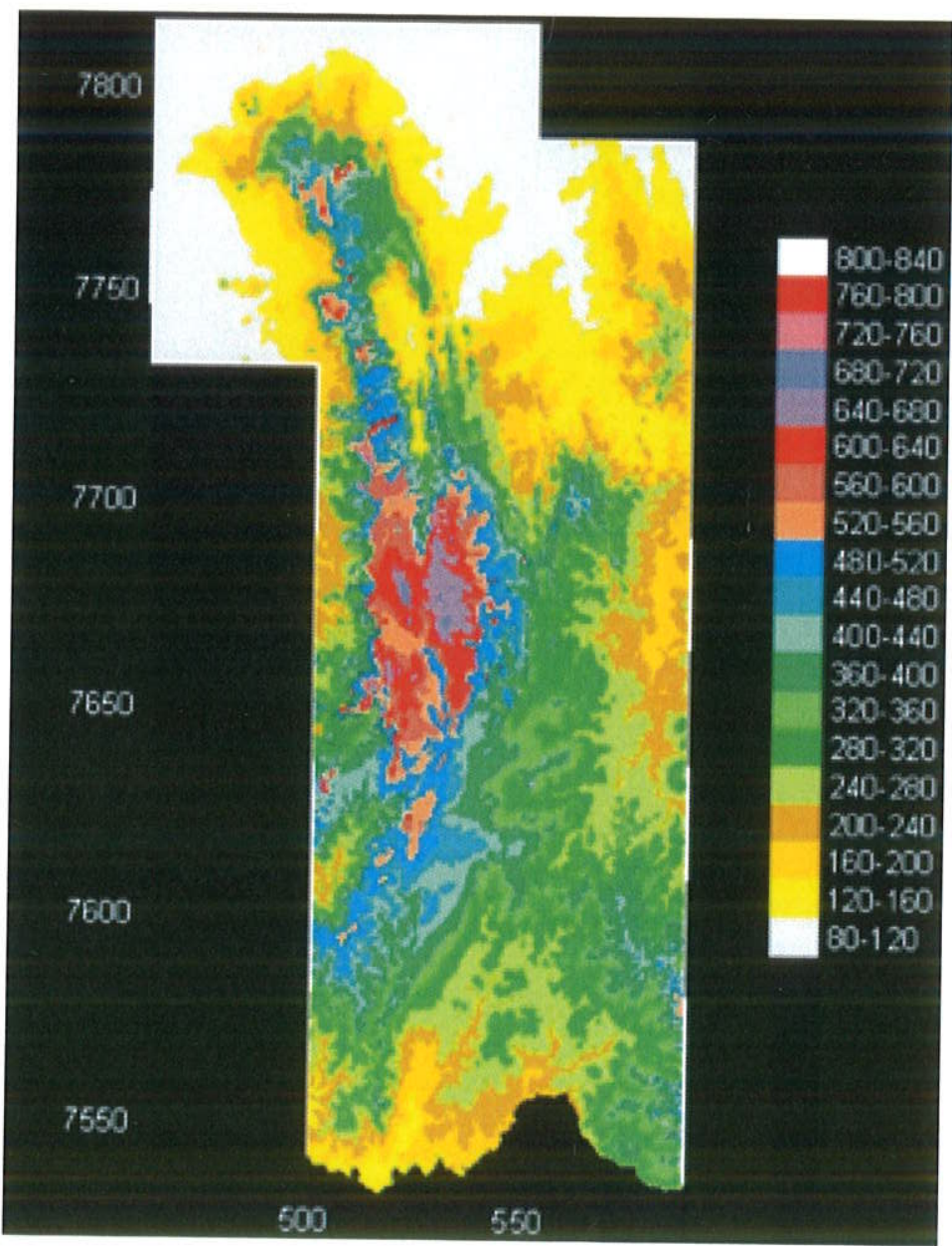

Fig. 1 - Mapa hipsométrico da Serra da Bodoquena

- Hypsometry of the Serra da Bodoquena

\section{Resumen:}

La Sierra de Bodoquena es una amplia meseta desarrollada en rocas carbonatadas del Grupo Corumbá, que resalta inmediatamente en las planicies del Estado de Mato Grosso do Sul. Una investigación pionera desde el punto de vista geológico y geomorfológico fue realizada por Almeida (1965). Al contrario de lo que indican los estudios más recientes, ese autor verificó una incoherencia entre las condiciones favorables para la formación de carst y la baja incidencia de rasgos cársticos en la región.

El sistema cárstico de la Sierra de Bodequena posee tres compartimientos principales de relieve: (i) la meseta de Bodoquena, sustentado por calizas, formada en la parte sur por carst autogénico, con pavimentos cársticos y carste poligonal; $y$ en la porción norte, un sistema fluvial conformado por ríos de cauces profundos, con menos influencia de un sistema cárstico; (ii) la depresión del Río Miranda, constituida esencialmente de dolomías, con elevaciones residuales y dolinas, asociadas con amplias planicies cársticas y rasgos de cavernas vadosas actualmente de bajo del nivel de agua (espeleotemas sumergidos) y (iii) en el extremo sur de la sierra ocurren campos de dolinas que muestran un compartimiento de relieve como un carst interestratos, desarrollado en areniscas de la Formación Aquidauana de la Cuenca del Paraná.

En cuanto a las cavernas, las mismas presentan tres principales patrones: 1) galerias de abatimiento irregular en planta y longitudinalmente formando planos inclinados, 2) cavernas en red anastomosada con conductos circulares a elipticos en planta y ramificaciones anastomosadas en sección transversal, 3) cavernas meandriformes en planta, a veces asociados con sumideros activos o fósiles, con inyección alogénica en la mayoría de los casos.

La influencia de una tectónica más reciente en la Sierra de Bodoquena es posible deducir por la proximidad de la misma a la Cuenca del Pantanal y por la presencia de espeleotemas subaéreos sumergidos, mesetas sustentados por calizas y planicies de dolomías, escarpas delimitando mesetas, en la porción norte de la meseta el cauce de los ríos son más profundos que en el extremo sur, posible captura de drenaje del Río Perdido; y una estructura linear que secciona la Sierra de Bodoquena.

Palabras llave: Geología, Geoespeleología, Carst, Geomorfología, Serra da Bodoquena.

\section{Introdução}

A Serra da Bodoquena é uma feição geomorfológica marcante no Estado do Mato Grosso do Sul, com cerca de 200 km na direção norte-sul e até 800 metros de altitude (Fig.1). Situa-se a sudeste da Planície do Pantanal entre $19^{\circ} 45^{\prime}$ e $22^{\circ}$ $15^{\prime}$ de latitude sul e entre $57^{\circ} 30^{\prime}$ e $56^{\circ} 15^{\prime}$ de longitude oeste.

Consiste de um planalto carbonático (serra propriamente dita) do Grupo Corumbá e de planícies de natureza terrígena e carbonática dos grupo Corumbá e Cuiabá, todos da Faixa Paraguai-Araguaia (Almeida et al., 1976; Boggiani \& Alvarenga, este volume) (Fig. 2).

No contexto desses dois compartimentos geomorfológicos principais, se desenvolvem sistemas cársticos, reunidos por Karmann \& Sánchez $(1979 ; 1986)$ na Província Espeleológica da Serra da Bodoquena.

O limite norte da Serra da Bodoquena é dado pelo recobrimento por sedimentos cenozóicos da Formação Pantanal e ao sul praticamente desaparece, ocorrendo apenas alguns morros isolados dos calcários do Grupo Itapucumi. Após a primeira citação da presença de carste e cavernas na região por Mendes (1957); Almeida (1965) faz uma primeira 


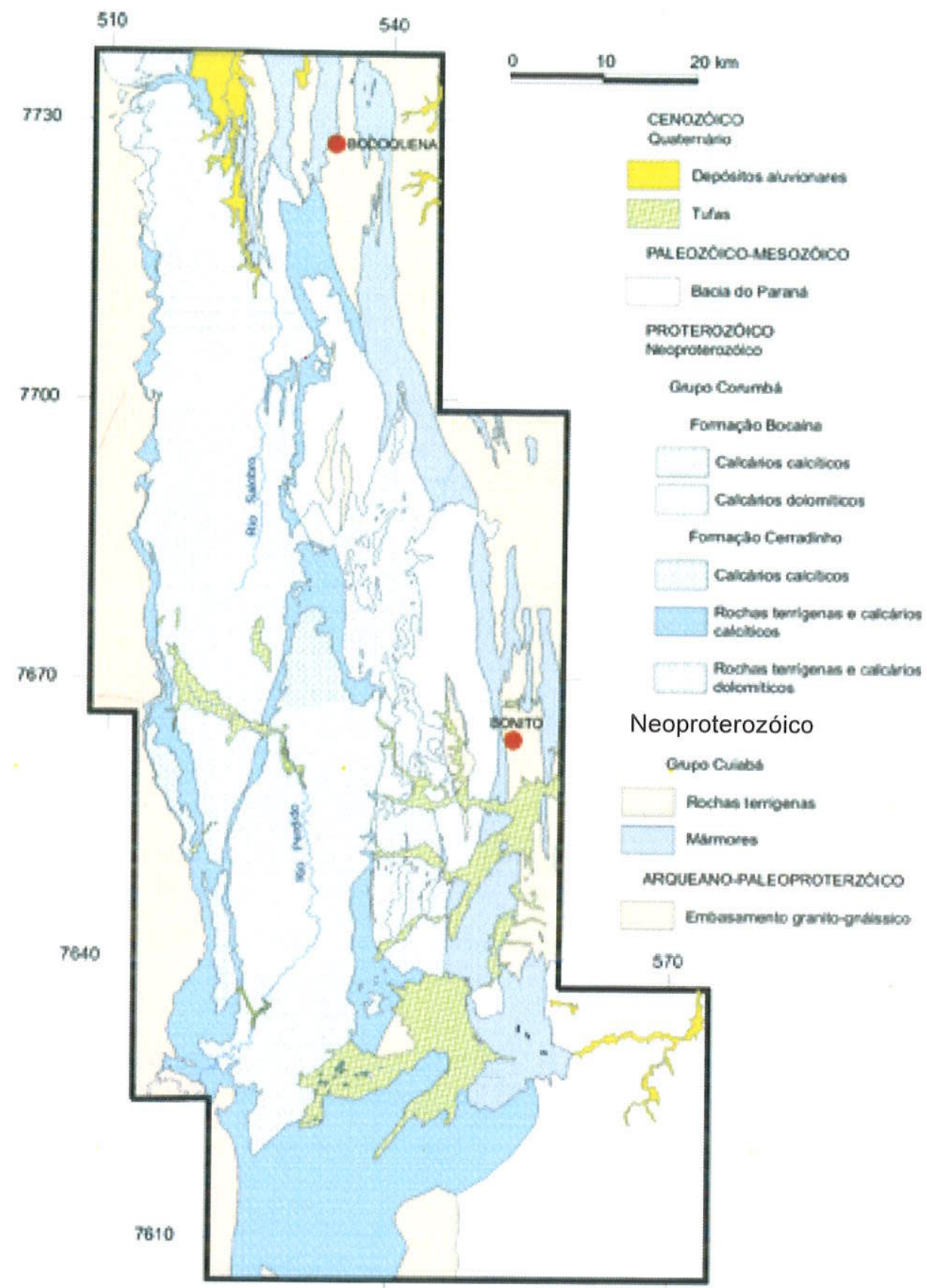

Fig. 2 - Mapa geológico simplificado com as unidades carbonáticas (Compilado de Nogueira \& Oliveira, 1978; Corrêa et al., 1976;

Araújo et al., 1982; Godoi, 2001)

- Geological outline showing carbonate rock units (Compiled from Nogueira \& Oliveira, 1978; Corrêa et al., 1976; Araújo et al., 1982; Godoi, 2001)

caracterização em seu trabalho Geologia da Serra da Bodoquena.

Existem poucos trabalhos realizados na Serra da Bodoquena que enfocam o carste. Estudos específicos são cada vez mais necessários devido ao aumento do aporte de turistas, acompanhado da respectiva infra-estrutura necessária e, principalmente, os voltados ao planejamento do uso da terra e os necessários para elaboração do plano de manejo do Parque Nacional da Serra da Bodoquena, criado no dia 21 de agosto de 2000 .

\section{Geomorfologia do carste da Serra da Bodoquena}

Almeida (1965) estabeleceu uma primeira compartimentação geomorfológica da área (Fig.3): Pantanal, Zona Cristalina Ocidental, Serra da Bodoquena, Zona Serrana
Oriental, Depressão Periférica do Miranda e Vale do Rio Apa. Segundo Almeida (1965, p. 81) a Serra da Bodoquena "é a mais importante feição geomorfológica regional, não só pelas altitudes a que se eleva, dentro do quadro de planícies do sul do Mato Grosso, como por sua extensão".

Em trabalho mais recente, Alvarenga et al. (1982), no projeto RADAMBRASIL, reconheceram na área de estudo quatro unidades geomorfológicas: o Planalto da Bodoquena, o Planalto de Maracaju-Campo Grande, a Depressão do Rio Paraguai, as Planícies e Pantanais Mato-grossenses. A classificação de Alvarenga et al. (1982) é a utilizada neste trabalho, apenas acrescentando a Depressão Periférica do Rio Miranda de Almeida (1965), que estaria incluída na Depressão do Rio Paraguai.

Na classificação de Almeida (1965) o carste corres- 


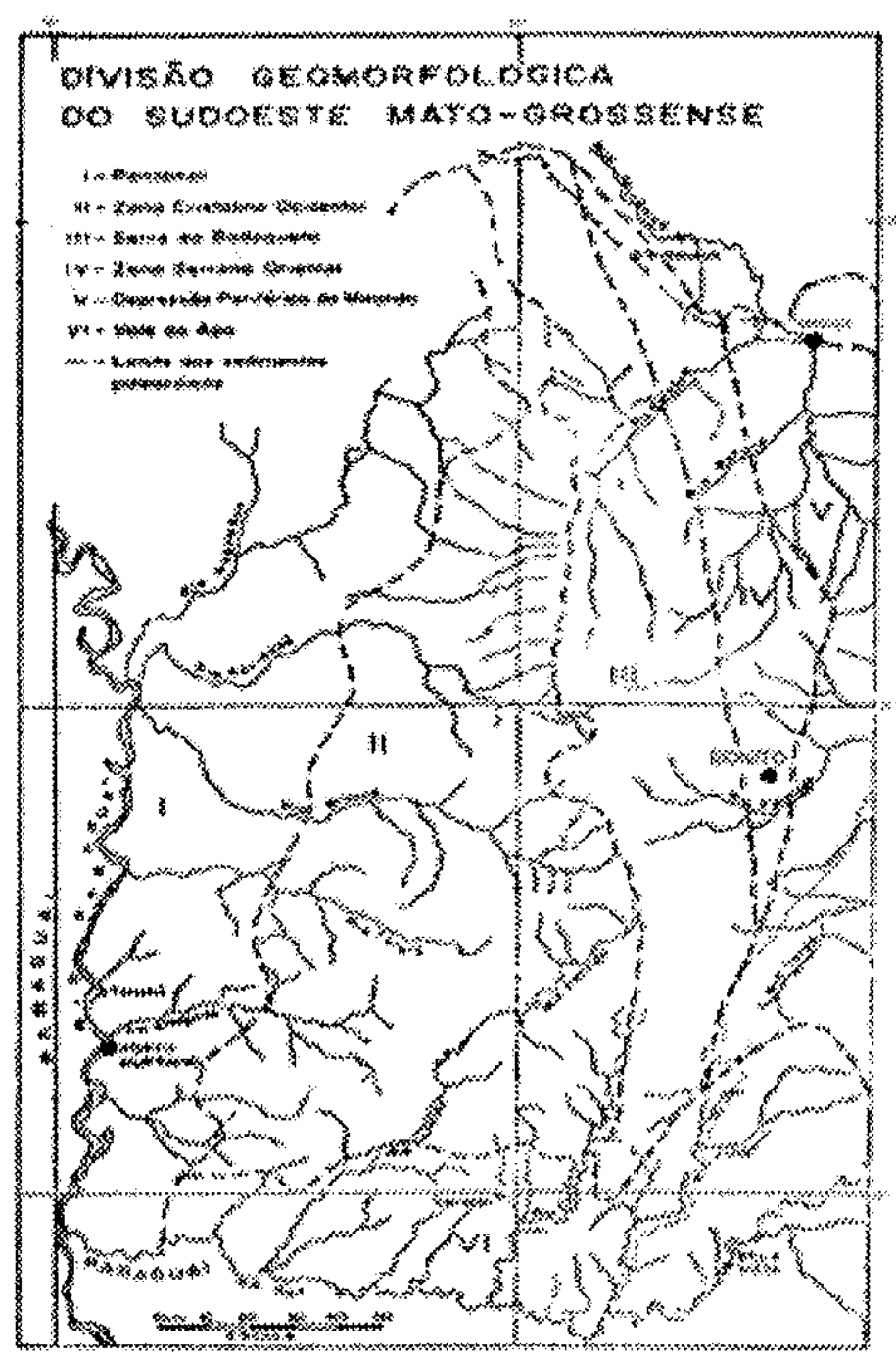

Fìg. 3 - Divisāo geomorfológica regional segundo Almıeida (1965)

- Regional geomorphological settings by Almeida (1965)

ponde às unidades da Serra da Bodoquena e de parte da Zona Serra Oriental, que correspondem respectivamente, na classificação de Alvarenga et al. (1982), ao Planalto da Bodoquena e a Depressão do Rio Miranda e ao Planalto de MaracajuCampo Grande.

Em relação ao carste, Almeida (1965, p. 83-84) descreve:

"Viajando-se na Bodoquena, certamente depara-se com aspectos tipicos do relevo calcário. A hidrografia é em parte subterrânea; adaptados às direçoes tectônicas, sobretudo nas regiões dobradas da borda oriental, os cursos d'água perdem-se freqüentemente, em sumidouros, tipicos avens afinilados, como o exibido na Fig. SC. Diz-se que grande parte do córrego Lalima e alguns de seus afluentes, na zona norte do planalto, tem desenvolvimento subterrâneo, e que o próprio rio Formoso no municipio de Bonito, assim se apresenta em seu alto curso. Um ou outro pequeno lago existe sobre o planalto; sobrevoamos um deles na zona norte. $\dot{E} d$ de supor que ocupem dolinas. (...) Embora tenhamos visto, no planalto da Bodoquena, muitas das feiçóes caracteristicas do carst, certo é que outras faltam ou escasseiam. Nunca vimos uma dolina tipica, seja no terreno ou indicada nas fotografias aéreas que atentamente examinamos, de grande área da zona norte. A despeito da existência de cursos subterrâneos, pare. ceu-nos que a maior parte da drenagem seja superficial, fluindo em vales que se apresentavam secos por ocasião de nossas viagens, realizadas no rigor da estiagem. Não parece existirem poldjés. O vale do córrego Lalima sugere tal feição, mas sua origem é certamente outra, ligada como se acha, d̀ erosão de uma anticlinal dolomitica com a exposição do núcleo, em Formação Cerradinho. A natureza grandemente detritica desta formação explica o relevo suave da depressão, uma centena de metros mais baixa que as cristas dolomiticas vizinhas, e a presença de solos ácidos, no interior de um planalto predominantemente constituido de rochas carbonatadas. De tal modo, apresenta-se a Bodoquena como um carst incompletamente desenvolvido, $e$ isso é surpreendente quando se consideram as condições favoráveis ali reunidas para o desenvolvimento do relevo cárstico. As rochas carbonatadas existem por toda parte, em pacotes de centenas de metros de espessura, expostos em clima relativamente úmido, cuja pluviosidade dove oscilar entre 1200 e $1300 \mathrm{~mm}$ e, o que é importante, concentra-se nos meses de wais elevadas temperaturas. O planalto ergue-se suficientumente acima do nivel das planicies do Pantanal para que seja grande a solicitação à infiltração subterrânea da drenagem."

Atualmente sabe-se que as feiçôes cársticas não são tão raras, nem o carste da Serra da Bodoquena é incompletamente desenvolvido, porém as feiçóes mais evidentes, como sumidouros e cavernas, não são tão comuns como em outras áreas carbonáticas. Existe um amplo sistema de condutos cársticos dominantemente em ambiente freático, atingindo grandes profundidades, evidenciado por cavernas subaquáticas e por informaçôes de poços perfurados na região. Grande parte da água subterrânea utilizada na Serra da Bodoquena provém de aquíferos cársticos. Dolinas, nascentes e cones cársticos são feiçōes relativamente comuns tanto no Planalto da Bodoquena quanto na Depressão do Rio Miranda.

O Planalto da Bodoquena (Serra da Bodoquena, Almeida, 1965) consiste de um "estreito e longo planalto calcondolomitic o" (Almeida, 1965, p. 81) com altitudes variando entre 350 e 800 metros, mais comumente entre 400 e 600 metros, composta principalmente de calcários calcíticos da Formação Bocaina e de rochas terrígenas e carbonáticas (calcíticas e dolomíticas) da Formação Cerradinho (de menor expressão em área), ambas do Gr. Corumbá (Fig. 1, 2, 4, 5D). Compõe um carste principalmente autogênico caracterizado na porção sul (Unidade $\mathrm{PB}_{1}$ ) por pavimentos cársticos (relevo com morros de topo plano recortados por vales na forma de fendas e corredores retilíneos com fundo estreito e vertentes verticais) gradando para áreas de carste poligonal dominado por cones cársticos (depressões poligonais com drenagem centripeta e cones cársticos), próximo à planície do Rio Perdido (Fig. 5A, B), ambos com solo pouco espesso ou ausente, formando lajedos. Nesse setor, o Rio Perdido apresenta trechos com curso subterrâneo. A porção norte (Unidade $\mathrm{PB}_{2}$ ) é composta por áreas fluviais, com o alto Rio Salobro como a principal drenagem, formando um canion, com afluentes em maior ou menor grau de entalhamento, alguns subterrâneos, e os interflúvios formando pavimentos cársticos e carste poligonal pouco desenvolvidos (Fig. 5G). No interior do Planalto da Bodoquena ocorrem planícies (Unidade $\mathrm{PB}_{3}$ ) formadas por rochas carbonáticas ou terrigenas. O trecho mais alto do Planalto da Bodoquena é sustentado por granitos intrusivos (Unidade $\mathrm{PB}_{5}$ ) (Fig. 1, 2, 4).

Segundo Almeida (1965) o Planalto da Bodoquena possui a borda ocidental escarpada em relação à Depressão do Rio Paraguai, considerada aqui como a unidade de relevo a oeste da área de estudos, rebaixada em relação ao Planalto da Bodoquena e limitada a leste pela mesma, com altitudes entre 150 a 450 metros e composta por rochas granito-gnáissicas do embasamento (Fig. 1, 4, 5D, 9A). Já a borda oriental termina "bruscamente ou em degraus, faz face às planicies desenvolvi. das nas grandes sinclinais da Zona Serrana Oriental" (Almeida, 
1965, p. 81) inserida hoje na Depressão Periférica do Rio Miranda, limitada a oeste com o Planalto da Bodoquena e a leste pelo Planalto de Maracaju-Campo Grande, com altitudes entre 100 a 300 metros, composta de rochas terrígenas e carbonáticas (principalmente dolomíticas) do Gr. Corumbá e por mármores (calcíticos e dolomíticos) do Gr. Cuiabá (Fig. 1, 2, $4,5 \mathrm{D}, 9 \mathrm{~B})$.

O carste na Depressão do Rio Miranda é composto essencialmente de morros residuais, mais freqüentes na Unidade $\mathrm{DRM}_{1}$ e mais isolados na Unidade $\mathrm{DRM}_{2}$, geralmente de calcário, formando cones cársticos (Fig. 4, 5F). Nas planícies associadas ocorrem dolinas, a maioria em solo residual do calcário dolomítico (Fig.6C). A Depressão do Rio Miranda, no Médio-Baixo Rio Salobro, se encontra inserida dentro da porção norte do Planalto da Bodoquena, em planícies aluviais, com alti- 7670 tudes comparáveis às do Pantanal Mato-grossense (80-250 m) (Unidade $\mathrm{DRM}_{3}$ ) (Fig. 1, 2).

O carste da Serra da Bodoquena se diferencia pela abundante ocorrência de tufas calcárias, ainda em formação, ao longo da drenagem ativa. Estas tufas calcárias são encontradas na forma de cachoeiras e de inúmeras barragens naturais ao longo dos principais rios que cortam o planalto (Boggiani \& Coimbra, 1995). Tufas pulverulentas formaram-se em meandros abandonados do Rio Formoso, constituindo depósitos de até seis metros de espessura, atualmente lavradas para corretivos de solo. A origem das cachoeiras e barragens de tufas se deve ao alto teor de bicarbonato de cálcio das águas dos rios, associadas à atividade combinada entre cianofíceas e musgo. Já as tufas pulverulentas podem ter sido originadas por indução durante a atividade fotossintetizante das cianofícias em águas paradas (Boggiani et al., 2000). Ao longo das drenagens atuais é comum observar a concentração de tubos calcários, os quais são atribuídos à permineralização e incrustação de talos de algas caráceas. Esses calcários quaternários foram descritos no trabalho de (Almeida, 1965). na Formação Xaraiés, unidade esta definida por ele mesmo na escarpa de Corumbá-Ladário (Almeida, 1945). Considera-se, porém, essa inclusão não apropriada, por serem as Tufas Calcárias da Serra da Bodoquena (Boggiani \& Coimbra, 1995) distintas dos calcretes da Formação Xaraiés, devendo portanto serem consideradas como unidades à parte.

Em sua porção norte, a Serra da Bodoquena apresenta um 'relevo de morros dolomíticos mais ou menos isolados que se erguem da superficie de aplainamento que, como grande pedestal, desce suavemente das abas da serra ao Pantanal do Miranda, nas vizinhanças da estação de Bodoquena, tal como o ilustra a fotografia 11" (Almeida, 1965). Nessa área poucas feições cársticas são conhecidas.
540 PB,: Pavimentos cársticos e
carste poligonal PB: $_{2}$ : Vale do Rio Salobro

PB: $_{3}$ Planicies

PB $_{4}$ : Serras e Morros

PB: Depósitos de tufas

DRM,: Planicies cársticas com morros residuais e dolinas

DRM, : Planicies com morros residuais isolados

DRM $M_{2}$ : Planicie aluviais do Médio-Baixo Rio Salobro

DRM 4 : Planicies com coberturas de tufas

PMCG,: Superficies aplainadas com dolinas Carste interestratal

NC: Rochas nằ carbonáticas

Fig. 4 - Compartimentação geomorfológica do carste da Serra da Bodoquena (base: imagem de radar SRTM )

- Geomorphological compartments of the Serra da Bodoquena Karst (base: radar image SRTM) 
Fig. 5 - Feições do relevo cárstico da Serra da Bodoquena. A- Imagem de satélite (R7G5B3 mais PC1 na intensidade, agosto de 2001) exibindo cones cársticos,

depressões poligonais e pavimentos cársticos na região do Rio Perdido

(Unidade $\mathrm{PB}_{1}$ ). $\mathrm{O}$ círculo vermelho indica o local da Fig.5B; B- Cones cársticos alinhados próximos ao Rio Perdido (Unidade $\mathrm{PB}_{1}$ ); CSumidouro no Planalto da Bodoquena (Almeida, 1965 , fotografia 16 ). Córrego Seputá, região de Três Morros (Unidade P B 1 ); D- Modelo digital de terreno do Planalto da Bodoquena e dos vales dos rios Perdido (sul) Salobro (norte)

(Unidades $\mathrm{PB}_{1}$ e $\mathrm{PB}_{2}$ ); E- Cones cársticos no Planalto da Bodoquena (Almeida, 1965 fotografia 12) (Unidade $P B_{1}$ ); F- Morros residuais de calcários dolomíti cos, alinhados, próximo à Bonito (Unidade DRM D $_{1}$; G- Modelo digital de terreno do setor norte do Planalto da Bodoquena (Unidade $\mathrm{PB}_{2}$ ), na borda ocidental, exibindo a escarpa ocidental do planalto e um trecho do do Rio Salobro

- Karst landforms of the Serra da Bodoquena. ASattelite image (R7G5B3 plus PC1 intensity August 2001) showing karst cones, closed depressions and limestone pavements of the Perdido River Área (Unit $\left.\mathrm{PB}_{1}\right)$. The red circle locates the Figure 5B; BAligned karst cones near the Perdido River (Unit $\mathrm{PB}_{1}$ ); $\mathrm{C}$ - Sink in the Bodoquena Plateau
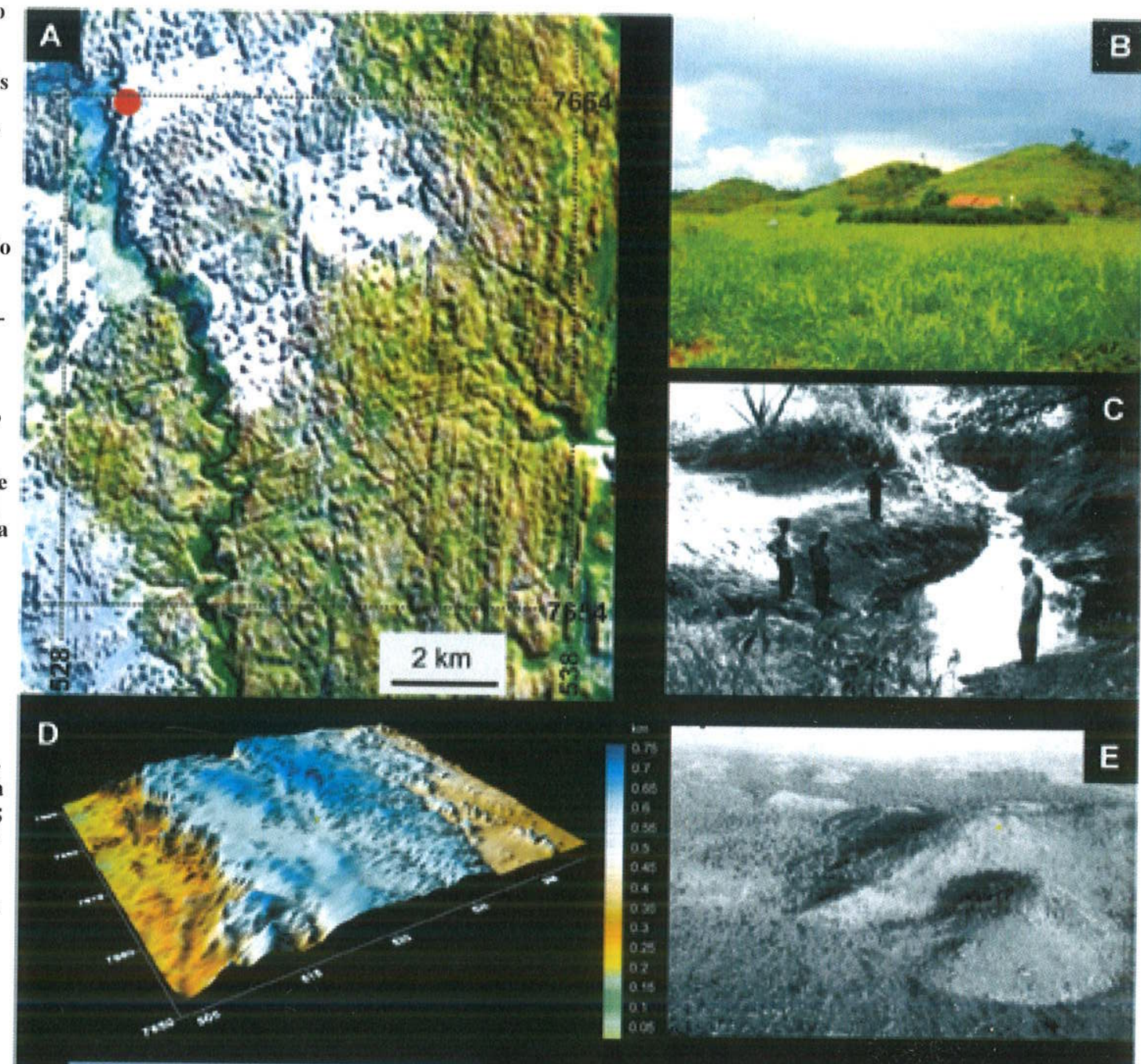

F
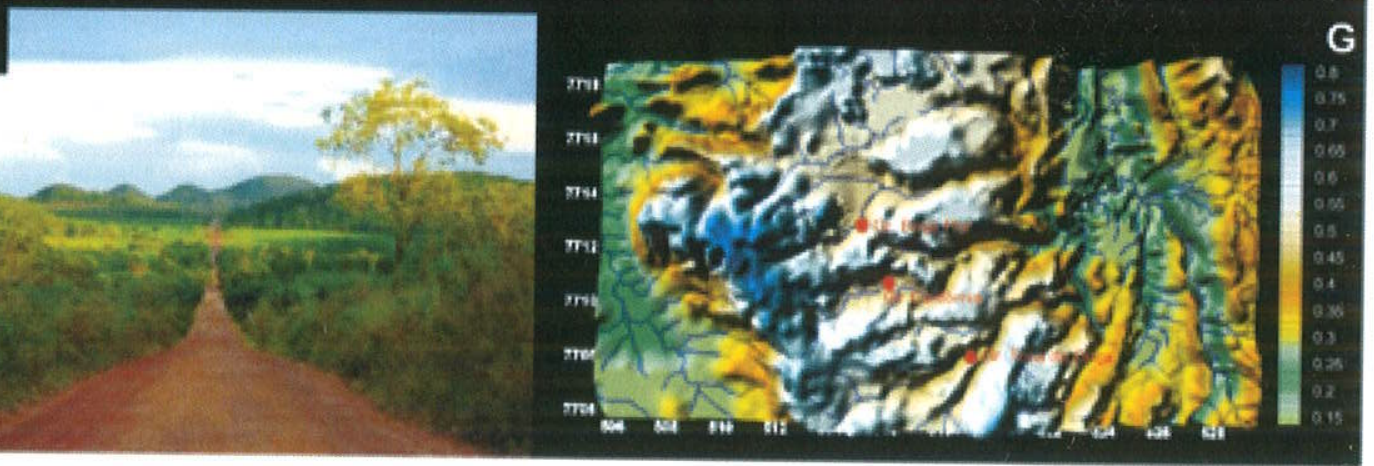

(Almeida, 1965, picture

16). Seputá Stream, Três

Morros region (Unit

$\mathrm{PB}_{1}$ ); D- Digital elevation model of the Bodoquena Plateau and Perdido (south) and Salobro (north) valleys (Units $P B_{1}$ and $\left.P B_{2}\right) ; E_{-}$ Karst cones in the Bodoquena Plateau (Almeida, 1965, picture 12) (Unit PB $)_{1}$; F- Aligned residual hills of dolomitic limestone near Bonito town (Unit DRM $)$; G- Digital terrane of model of the north sector of the Bodoquena Plateau (Unit PB $B_{2}$, showing the western border with escarpment of the plateau and a sector the Salobra River canyon

Na porção sul da Serra da Bodoquena, o Planalto da Bodoquena dá lugar a extensas planícies desenvolvidas sobre a Formação Cerradinho, mármores do Grupo Cuiabá ou arenitos da Formação Aquidauana (Carbonífero da Bacia do Paraná). Trata-se de uma superfície aplainada com cotas entre 200 e 400 m. No domínio da Formação Cerradinho, e também no Grupo Cuiabá, a superfície plana é interrompida pela ocorrência de dolinas, com diâmetros desde alguns metros até várias dezenas de metros, e profundidades também muito variadas, atingindo até 70 metros. A superfície carbonática gradativamente submerge na cobertura arenítica da Formação
Aquidauana, no sentido E-SE, onde a incidência de dolinas também é significativa, com depressões que atingem até 700 metros de diâmetro, como por exemplo a dolina da Fig. 6A, e o Buraco das Araras (Fig. 6B). Estas feições de colapso e erosão subterrânea nos arenitos evidenciam o desenvolvimento de um sistema cárstico profundo, em ambiente freático, nas rochas carbonáticas abaixo dos arenitos Aquidauana, caracterizando desta maneira, um carste interestratal associado principalmente à Formação Cerradinho, e também aos mármores do Grupo Cuiabá (Unidade $\mathrm{PMCG}_{1}$ ).

Um fato interessante observado nesta compartimen- 


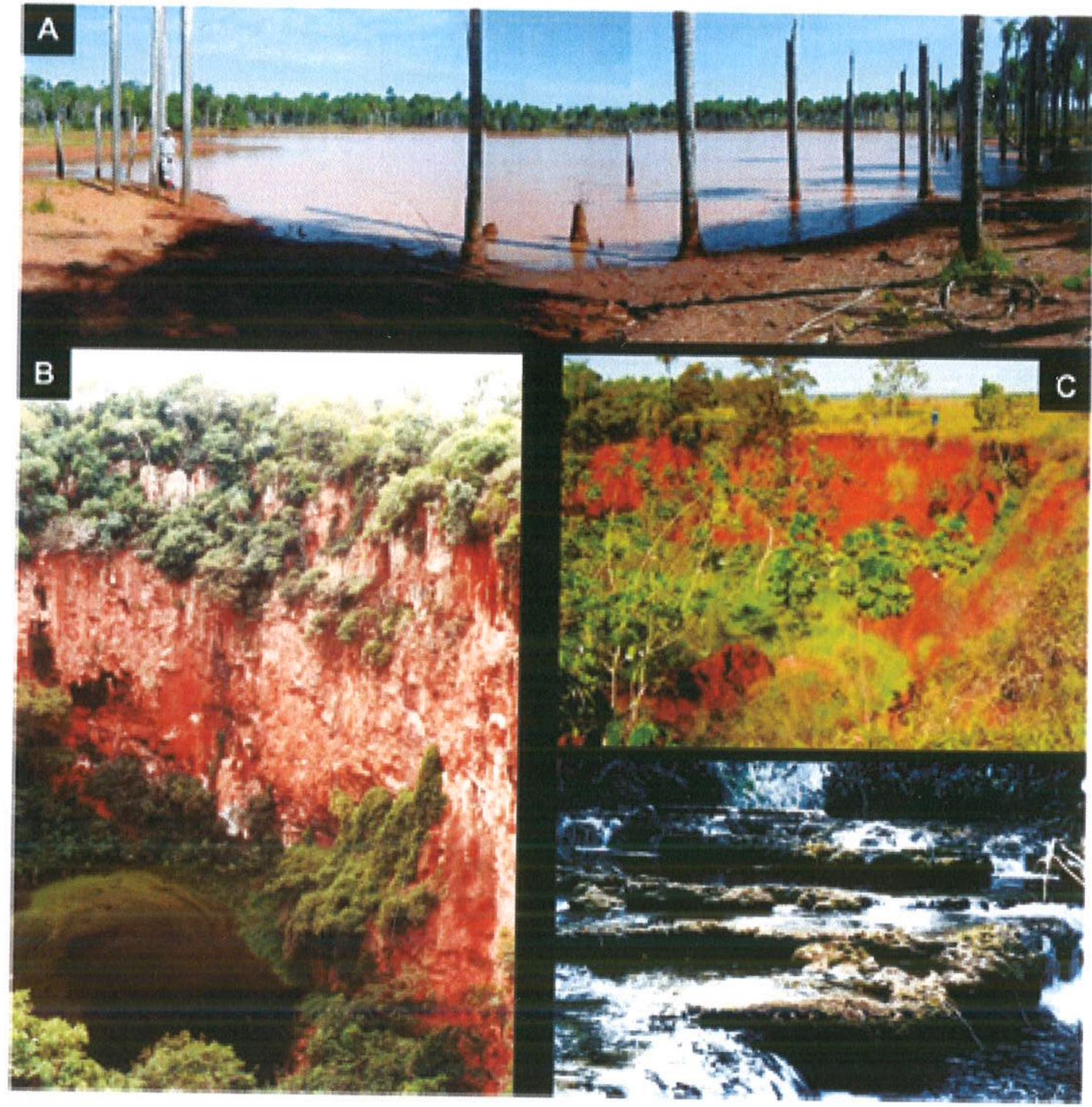

Fig. 6 - Feições do relevo cárstico da Serra da Bodoquena. A- Lago formado em dolina ampla e rasa, em arenitos da Formação

Aquidauana na Fazenda

Chapéu de Pano, sul da Serra da Bodoquena

(Unidade PCMCG1); BDolina escarpada e profunda, chamada de Buraco das

Araras, em arenitos da

Formação Aquidauana, próximo a Jardim, sul da

Serra da Bodoquena (Unidade PCMCG1); CDolina desenvolvida em solo, na beira da estrada de terra

Bonito-Jardim (Unidade

DRM $_{1}$ ); D- Represas de tufas no Rio do Peixe, $15 \mathrm{~km}$ ao norte de Bonito (Unidade DRM $_{1}$ )

- Karst features of the Serra da Bodoquena. A- Lake in a wide and shallow doline, developed in Aquidauana Sandstones formation, southern part of the Serra da Bodoquena (Unit

PCMCG1); B- Deep and scarped doline, called Buraco das Araras (Araras Hole), in Aquidauana Formation sandstones, near Jardim town, south Serra da Bodoquena (Unit PCMCG1); C- Doline in soil close to the Bonito-Jardim road (Unit DRM $)$; D- Tufa dams in the Peixe River, 15 $\mathrm{km}$ at north of the Bonito town (Unidade DRM 1 )

tação geomorfológica é que o Planalto da Bodoquena é constituído por calcários calcíticos, enquanto as planícies e morros isolados da Depressão do Rio Miranda (ou Zona Serrana Oriental) por calcários dolomíticos (Fig. 1, 2, 4, 5D). É um fato inesperado, pois a unidade mais solúvel (calcítica) encontrase ressaltada no relevo, enquanto a unidade menos solúvel (dolomítica), ao contrário do esperado, encontra-se deprimida em relação à calcítica.

\section{Cavernas da Serra da Bodoquena}

A primeira descrição no meio científico de cavernas na Serra da Bodoquena é de Mendes (1957) que, em visita a Serra da Bodoquena, registra a ocorrência de pelo menos três grutas, além de outras feições cársticas na região. Apresenta esboços cartográficos e uma descrição geológica das grutas do Lago Azul (Gruta da Fazenda Anhumas), com uma seção esquemática mostrando um lago raso no interior da gruta (Fig. 7A) e Nossa Senhora Aparecida (Gruta da Fazenda Três Irmãos). Mendes (1957) ainda descreve a geologia regional, e chama atenção da potencialidade espeleológica da região.

Em relação às cavernas, Almeida (1965, p. 83) cita que:

"Pequenas grutas diz-se que são numerosas, sobretudo na borda oriental do planalto, e pelo menos duas grandes grutas em dolomitos existem no municipio de Bonito".

Atualmente existem 78 cavernas cadastradas na Sociedade Brasileira de Espeleologia (dados de novembro de 2003) na região da Serra da Bodoquena (Tabela 1).

\begin{tabular}{|l|l|}
\hline № de cavernas cadastradas & 78 \\
\hline № de cavernas mapeadas com precisão & 30 \\
\hline Desenvolvimento total (62 cavernas) & 13986,7 metros \\
\hline Desenvolvimento médio (63 cavernas) & $\begin{array}{l}202,7 \text { metros } \\
\text { (min. } 8 \text { e máx.1900 m) }\end{array}$ \\
\hline Desnível médio & $\begin{array}{l}29,9 \text { metros } \\
(\text { min. } 0 \text { e máx.220 m) }\end{array}$ \\
\hline
\end{tabular}

Tabela1. Dados morfométricos das cavernas da Serra da Bodoquena.

-Morphometric data of the Serra da Bodoquena

Um mapa de uma caverna com seu respectivo desenvolvimento e desnível, representa apenas parte do que existe na realidade. A maior caverna conhecida na região, o Buraco das Abelhas, possui 1900 metros de desenvolvimento e 58 metros de desnível, tratando-se de uma caverna freática (surgência). Em comparação com outras áreas cársticas do Brasil, a Serra da Bodoquena apresenta baixa incidência e pequeno desenvolvimento de cavernas. Por exemplo, para os Grupos Uma (BA) e Grupo Açungui (SP), Auler et al. (2001) considerando as cinqüentas maiores cavernas do Brasil, obtiveram totais de desenvolvimento de cavernas de 240 e 29 
ração, mapeamento e de pesquisa nas cavernas da Serra da Bodoquena. Lino et al . (1984) descreveram a presença comum de sumidouros, apesar da predominância da drenagem superficial, os que podem ocorrer associados aos leitos fluviais superficiais, que retomam seu curso superficial normal nas épocas mais chuvosas (Lino et al., 1984). Esta drenagem subterrânea é penetrável apenas através de mergulho (Lino et al., 1984). Lino et al. (1984) também descreveram a ocorrência de dolinas, princinalmente na região ao sul de Bonito, como o caso da Lagoa Misteriosa e arredores.

Karmann \& Sánchez (1979;1986) definem a "Província Espeleológica da Serra da Bodoquena", localizada no Estado do Mato Grosso do Sul e distribuida por $200 \mathrm{~km}$ na direção N-S. Segundo esses autores, na regiao da Serra da Bodoquena não se observa um carste típico, mas sim um con algumas características isoladas, como dolinas, sumidouros e ressurgências, raramente associadas a cavernas. Karmanı \& Sánche $(1979 ; 1986)$ citam que as cavernas mostram um avançado grau de evolução, com grandes salões de abatimento ao longo de planos de acamamento e juntas, que frequentemente estão abaixo do nivel da água.

Na década de 1990 projetos visando a exploração de cavernas submersas tiveram início. Em 1991 uma equipe franco-brasileira realizou mergulhos na Gruta do Lago Azul, Gruta do Mimoso, no Abismo Anhumas e na Nascente do Rio Fomoso, dentro do que denominou-se "Expediçáo Bonito'91" (Auler, 1991). Além da elaboração de croquis das grutas exploradas tentou-se também determinar a conexão do Abismo Anhumas com a Gruta do Lago Azul, por estas estarem próximas, mas não foram encontrados condutos latem rais no lago do abismo; foi também explorada una gruta seca, a Cruta Pitangueiras, de padrão labirintico. Outra expedição franco-brasileira foi realizada em 1992, na "Expedição franco-brasileira Bonito' 92", onde o trabalho de exploração subaquática foi expandido e foram exploradas e mapeadas as porções submersas das Grutas do Lago Azul, Gruta do Mimoso, Abismo Anhumas, nascente do Rio Formoso e Lagoa Misteriosa (Auler, 1992; Auler \& Boller, 1992). Em 1992, os franceses participantes da 'Expedicão Bonito' 92" fizeram una publicação em seu pais entitulada "Plonger dans la Prehistoire Bresilienne" (Mergulho na Pré-História Brasileira, Rosello et al., 1992) na qual eles divulgam a região de Bonito, e as descobertas de ossadas de Eremotherium, Smilodon e Glyptodon.

Os dois últimos projetos de exploração e mapeamento de cavernas na região foram de Ginaspini et al. (1994) e de Ayub et al. (1996). Gnaspini et al. (1994) cadastraram e topografaram 21 cavernas na área e agruparam as cavernas cm cinco regiões com diferentes tipologias, fazendo também un levan tamento faunistico. Neste trabalho, foi apresentada a topografia incompleta da Gruta Pitangueiras, com $532 \mathrm{~m}$ de desenvolvimento, sendo considerada a maior caverna conhecida do Mato Grosso do Sul. Já o trabalho de Ayub et al. (1996), dentro da Expedição Bonito'95 /PROJETO AKAKOR apresenta 21 cavernas mapeadas. Ayub et al. (1996) sugerem, de maneira preliminar, a existência de dois tipos principais de cavernas: um mais comum (ou mais conhecido) de grandes saloes de abatimento e outro de cavernas menores e com morfologia original preservada. Esses dois tipos de cavenas parecem estar distribuídos, grosso modo, em duas faixas N-S, sendo o primeiro localizado na porção oriental da serra, e o segundo na porçáo ocidental, que aparentemente são condicionadas estruturalmente, correspondendo respectivamente às zonas mais e menos deformadas.

Atualmente sấo reconhecidos pelo menos três padrôes morfológicos principais que correspondem a compartimentos geomorfológicos especificos:

- Saloes de abatimento irregulares em planta, formando planos inclinados em seção transversal (Fig. 7B), como nas Gruta Lago Azul, Antumas e Mimoso. Encontram-se nas unidades $\mathrm{DRM}_{1}$ e DIRM $\mathrm{em}_{2}$ ambiente vadoso ou frético submerso com a presença de lagos (Fig. $7 \mathrm{~B}, \mathrm{C}$ ) e espeleotemas subaéreos submersos (Fig. $7 \mathrm{H}$ ).

- Cavernas em rede anastomosada em planta, com condutos circulares a elípticos e ramificações anastomosadas em seção transversal (Fig. 7D). Encontram-se nas unidades $P_{B}$ e $\mathrm{PB}_{2}$ em ambiente vadoso ou frético (Fig. $7 \mathrm{E}, \mathrm{F}$ ). Também ocorrem, na Unidade DRM $_{1}$, como fragmentos de sistemas de cavernas em alguns morros residuais, como no caso da Gruta Pitangueiras.

- Cavernas meandrantes em planta (Fig. 7G), por vezes associados a sumidouros ativos ou fósseis, com injeçåo alogênica na maioria dos casos,como nas grutas Beija Flor c Guaicurus. Em seção transversal apresentam seção de ampliação freática e vadosa, com presença de cúpulas em alguns locais (Fig. 7G). Ocorrem nas unidades $\mathrm{PB}_{1} \mathrm{e} P \mathrm{~PB}_{3}$

\section{Tectônica e relevo cárstice}

Desde os trabalhos de Almeida $(1945 ; 1965)$ nos estados do Mato Grosso e Mato Grosso do Sul, estudos sobre a origem tectônica da Bacia do Pantanal foram realizados, conforme detalhado por Assine (Vide Capítulo IV). Pela sua proximidade com o Pantanal e por representar uma de suas bordas elevadas, diversos autores já chamaram a atenção para a existência de movimentações recentes na Serra da Bodoquena. Porém, nenlum trabalho especifico sobre este assunto foi realizado, os poucos trabalhos já realizados se concentram na região do Pantanal.

Algumas feições sugerem movimentos tectônicos recentes na região, representadas na Fig. 8 :

1. Presença de espeleotemas subaéreos submersos: Esses espeleotemas subaéreos foram identificados até 20 metros de profundidade abaixo do nível d'água médio, considerando as variaçбes sazonais (Gruta Mimoso, Fig. 7H, e Abismo Anhumas). Esse valor é muito alto para ser efeito somente de variações climáticas, principalmente por se tratar de uma área continental, distante do litoral. Atribui-se influência de subsidência tectônica nesta submersão de espeleotemas.

2. Planalto sustentado por calcários calcíticos e planicies dolomíticas: Esse fato, já discutido anterionmente, chama a atenção, pois se considera os calcários calciticos mais solúveis que os dolomíticos, esperando-se, portanto os calcíticos mais rebaixados no relevo. Mesmo em relação à Depressão do Rio Paraguai, a oeste do Planalto da Bodoquena, que é composta de rochas gnáissicas e graniticas, os calcários calcíticos (Planalto da Bodoquena) estão mais elevados. $O$ Planalto da Bodoquena é um divisor de águas entres as depressôes e bacias do Rio Miranda e a do Rio Paraguai, delimitado por escarpas reafeiçoadas que sugerem movimentos tectonicos recentes (Fig. 5D), onde o planalto estaria $\mathrm{cm}$ soerguimento relativamente às áreas deprimidas, que estariam em subsidencia, justamente onde estão localizadas as cavernas com os espeleotemas subaereos submersos.

3- Escarpas delimitando o Planalto da Bodoquena: A escarpa ocidental da Serra da Bodoquena, que separa o Planalto da Bodoquena da Depressão do Rio Paraguai, com desniveis de até 500 metros, poderia ser interpretada como uma escarpa de crosáo remontante de origem estratigráfica ou tectônica (Fig. 5D, 9A). Essa escarpa poderia estar associada às rochas mais resistentes que mantêm o relevo mais elevado. O problema de termos apenas a erosão remontante de uma 
Fig.7 - Aspectos gerais das cavernas da Serra da

Bodoquena. Gruta do Lago Azul: A- Perfil longitudinal esquemático elaborado por Mendes (1957, fig. 6), BPerfil longitudinal da porção seca (Ivo Karmann e Paulo Cesar Boggiani, em Lino et al., 1984) e submersa (Marcos Augusto Philadelphi, Inédito), C- Fotografia do lago; Gruta Califórnia: D- Fotografia de uma seção no fundo da caverna exibindo um conduto principal e galerias anastomosadas laterais, desenvolvidas no acamamento; Nascente do Rio Formoso: E- Perfil longitudinal (parcial - Leandro Dybal Bertoni, Inédito), F-

Fotografia da nascente; Gruta da Onça: G- Perfil longitudinal e planta da caverna exibindo padrão anastomosado com cúpulas; Gruta

Mimoso: H- Estalactites submersas com revestimento de crosta subaquática $(-12 \mathrm{~m})$

(Fotografia de Ismael Escote)

- General views of the Serra da Bodoquena caves. Lago

Azul Cave: A- Schematic longitudinal profile by Mendes (1957, fig. 6), B- Longitudinal profile of the cave above the water level (Ivo Karmann and Paulo Cesar Boggiani, in Lino et al., 1984) and the sub-

merged cave (Marcos Augusto Philadelphi, unpublished), CLake of the cave; Califórnia Cave: D- Picture of a cave section showing the main gallery with lateral anastomosing conduits, guided by bedding planes; Rio Formoso Spring: E- Longitudinal profile (partial - Leandro Dybal Bertoni, unpublished), FSpring of the cave; Onça Cave: G- Longitudinal profile and cave map showing anastomotic pattern with cupolas;

Mimoso Cave: H- Submerged stalagmites with subaqueous crust $(-12 m)$ (Photo by Ismael Escote)
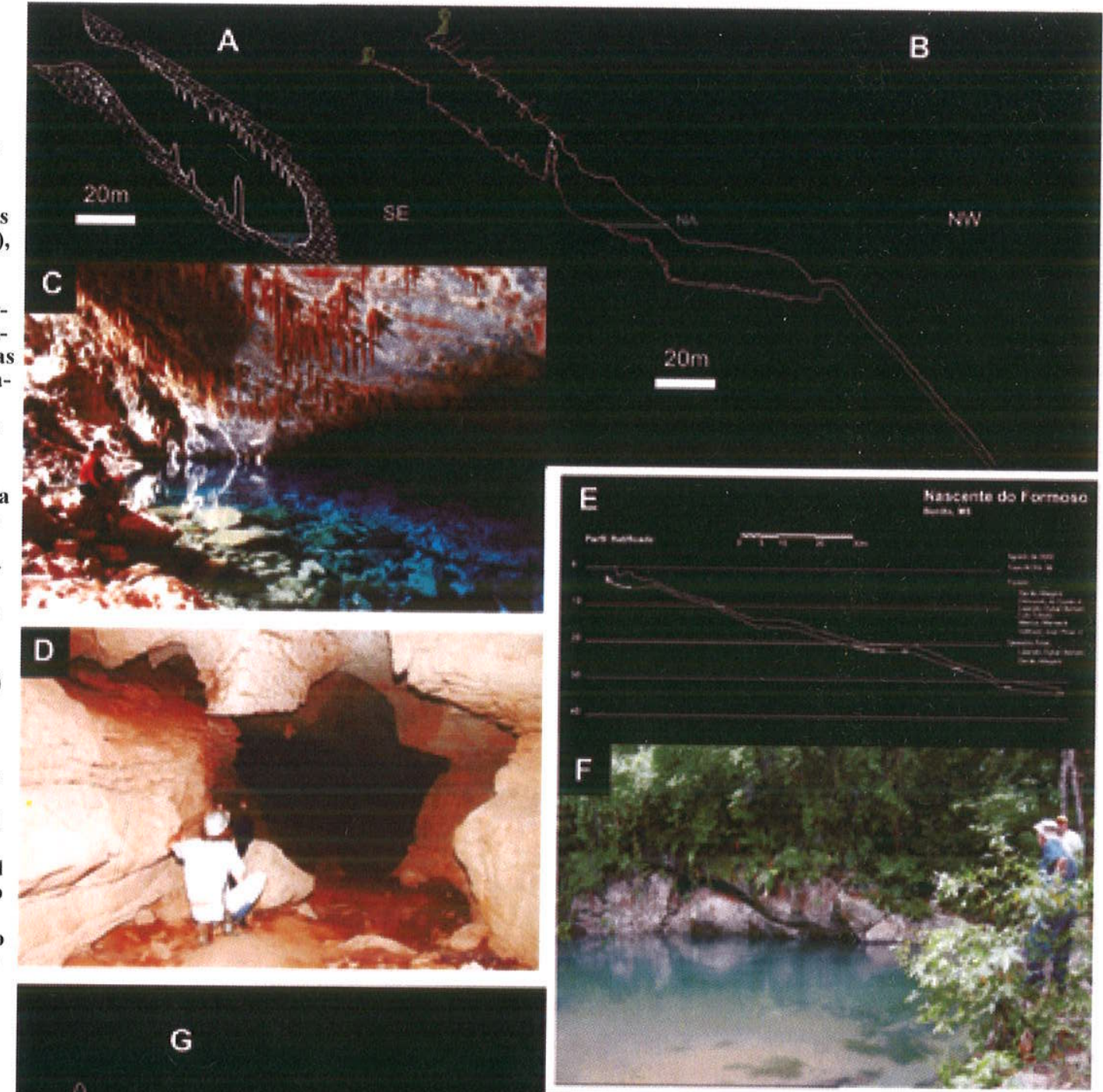

G

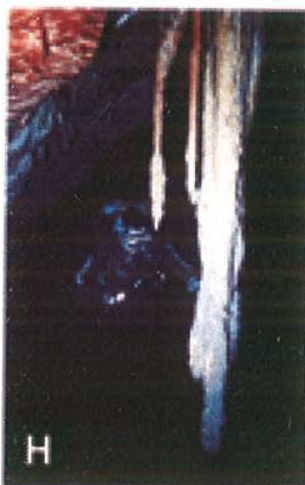

Perfil longitudina

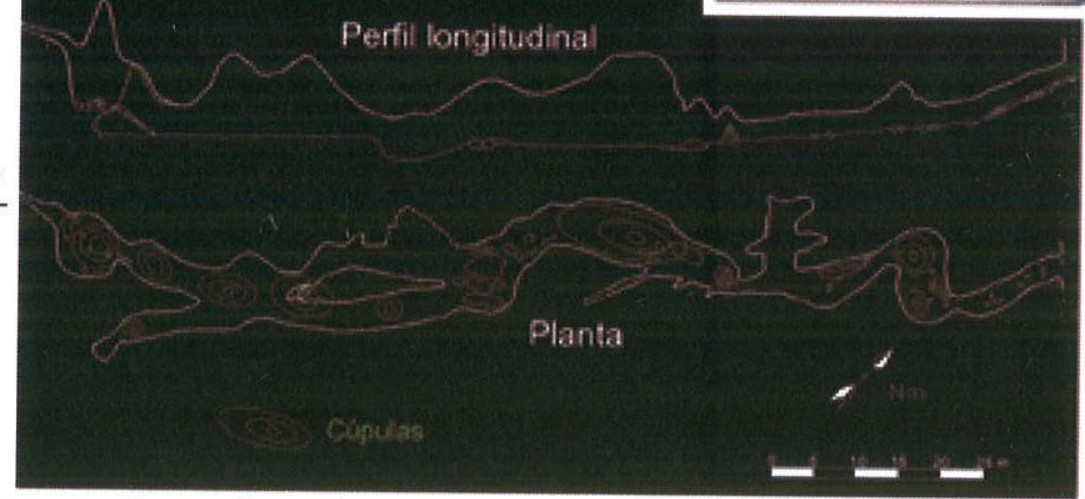

$\mathrm{H}$ quilômetros, respectivamente. Para a Serra da Bodoquena, obteve-se um desenvolvimento total de 13 quilômetros de cavernas (Tabela 1).

Dois fatores contribuem para esse fenômeno. Houve poucos projetos de mapeamento e exploração de cavernas na região, comparado a outras regiões do Brasil, o que dificulta uma análise mais objetiva. Porém todos os projetos existentes na região chamam a atenção para o fato de que na Serra da Bodoquena não ocorre grande quantidade de cavernas, ou seja, a densidade de cavernas é baixa, e também com baixo desenvolvimento médio. Por outro lado, a quantidade de cavernas submersas é maior que em outras regiões. Provavelmente os maiores sistemas de cavernas da Serra da Bodoquena são submersos, e ainda estão no início da sua exploração e mapeamento.

Almeida (1965) visitou também a Gruta do Lago Azul e notou que ela teria se desenvolvido ao longo de juntas ortogonais ao acamamento, ao contrário do descrito por Mendes (1957), fato este muito importante para o entendimento da formação desta cavidade, como posteriormente analisado por Lino et al. (1984) (Fig. 7B, C):

"Trata-se de uma cavidade inclinada, profunda de uma centena de metros, possuindo belo lago de águas azuladas. Josué C. Mendes, que a visitou em 1956, descreve-a brevemente, indicando que concorda com a queda das camadas (Fig. 6), mas realmente essa gruta abriu-se por infiltrações ao longo de juntas muito regulares, quase normais às camadas, que nela se inclinam de $45^{\circ}$ para leste, na aba de uma sinclinal assimétrica em dolomitos da Formação Bocaina" (Almeida, 1965, p. 83).

Lino et al. (1984) realizaram, através do "Projeto Grutas de Bonito", o primeiro trabalho sistemático de explo- 


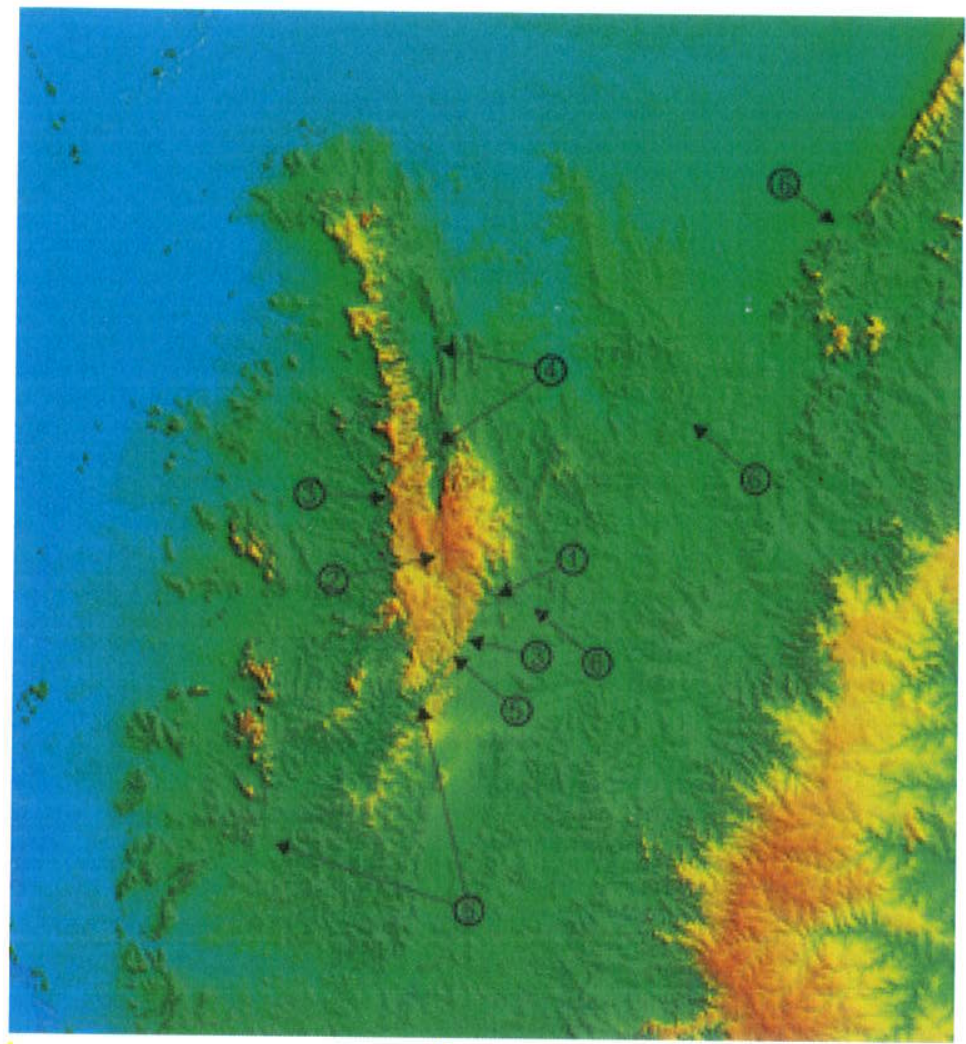

Fig. 8 - Principais feições que sugerem movimentos tectônicos recentes na área (base: imagem de radar SRTM, 2003). 1- Cavernas com espeleotemas subaéreos submersos; 2- Planalto sustentado por calcários calcíticos; 3- Escarpas do Planalto da Bodoquena; 4- Rios entalhados; 5- Possíveis capturas de drenagem do Rio Perdido; 6Estrutura linear que cruza a Serra da Bodoquena

- Main features that suggest recent tectonic movements in the studied area (base: radar image SRTM, 2003). 1- Caves with submerged subaerial speleothems; 2- Calcitic limestone plateau; 3- Bodoquena Plateau scarps; 4- Entrenched rivers; 5- Possible Perdido River capture; 6- Linear structures cutting the Serra da Bodoquena

camada mais resistente é o mesmo levantado no item 2, pois os calcários calcíticos que compõe o Planalto da Bodoquena não poderiam estar agindo como rochas mais resistentes que mantêm o relevo elevado, em relação aos gnaisses e granitos mais baixos. A hipótese de origem tectônica dessa escarpa já havia sido levantada por Almeida (1965), que possuía dúvidas, na época, da origem tectônica da Bacia do Pantanal:

"A suposição de existir uma tectônica de falhas submeridianas à borda oriental da bacia do Gran Chaco, a oeste da Bodoquena, relaciona-se a uma segunda questão geomorfológica levantada pela presente investigação, qual seja a origem das escarpas ocidentais do planalto da Bodoquena. Seja qual for, certamente tais escarpas representam, atualmente, um abrupto fronte de erosão remontante, que em seu recuo vem abandonando relevo residual mantido pelas rochas mais resistentes, que se ergue de superficies topográficas baixas e pouco acidentadas das rochas xistosas. Se comprovada for a presença de uma tectonica de falhas submeri dianas nas vizinhanças do rio Paraguai, o frontão abrupto da Bodoquena pode muito bem constituir a frente escarpada de um grande bloco de falha".

Na porção sudeste do Planalto da Bodoquena temos uma escarpa que delimita o planalto (Unidade $\mathrm{PB}_{1}$ ) das planícies da Depressão do Rio Miranda (Unidades $\mathrm{DRM}_{1}$ e $\mathrm{DRM}_{2}$ ), com desníveis de até 400 metros (Fig. 5D, 9B). Novamente temos a questão já discutida anteriormente de que os calcários calcíticos não poderiam estar mais elevados de que os calcários dolomíticos que compõem as planícies, considerando condições climáticas úmidas.
4- Porção norte do planalto com rios mais entalhados que o sul: O Planalto da Bodoquena é subdividido em dois blocos principais, um ao norte com feições fluviais mais marcantes em relação às cársticas e com rios entalhados (canions) (Unidade $\mathrm{PB}_{2}$ ) (Fig. 5G), e outro ao sul com feições cársticas mais freqüentes e poucas feições fluviais (Unidade $\mathrm{PB}_{1}$ ), compondo duas bacias hidrográficas distintas. Visto que são formadas pela mesma rocha (calcário calcíticos) com estruturas similares, temos o bloco norte mais entalhado devido a um maior soerguimento tectônico relativo, pois o bloco em subsidência, neste caso, é o próprio Pantanal. Destaca-se o entalhamento do canyon do Rio Salobro que alcança até 400 metros de profundidade, e também do Córrego Serra (próximo a Morraria) que chega a 300 metros. Na vertente sul do vale do Córrego Serra encontra-se a Gruta Urubu-Rei que é uma nascente suspensa a cerca de 150 metros acima do nível do rio, o que evidencia um entalhamento fluvial muito mais intenso que a taxa de denudação cárstica e entalhamento vadoso ao longo de condutos cársticos. Além disso, nessa nascente a fonte da água é de origem provavelmente freática profunda, surgindo de uma fenda que ocorre no final da caverna. O baixo Rio Salobro quando atinge o nível de base regional, em torno de 100 metros de altitude, forma uma grande planície (Unidade $\mathrm{DRM}_{3}$ ) dentro do próprio Planalto da Bodoquena, comparável às planícies da Depressão do Rio Miranda.

5- Possíveis capturas de drenagem do Rio Perdido: Em dois pontos o Rio Perdido muda de curso abruptamente, o que sugere capturas de drenagem. No primeiro ponto o rio segue de norte para sul e muda de curso, seguindo para sudoeste, próximo à escarpa entre o Planalto da Bodoquena (Unidade $\mathrm{PB}_{1}$ ) e a Depressão do Rio Miranda (planícies Unidade $\left.\mathrm{DRM}_{1}\right)($ ver itens 2 e 3$)$. Já no segundo ponto o rio muda de curso mais para oeste, seguindo uma estrutura linear de expressão regional detalhada a seguir no item 6. Estes pontos
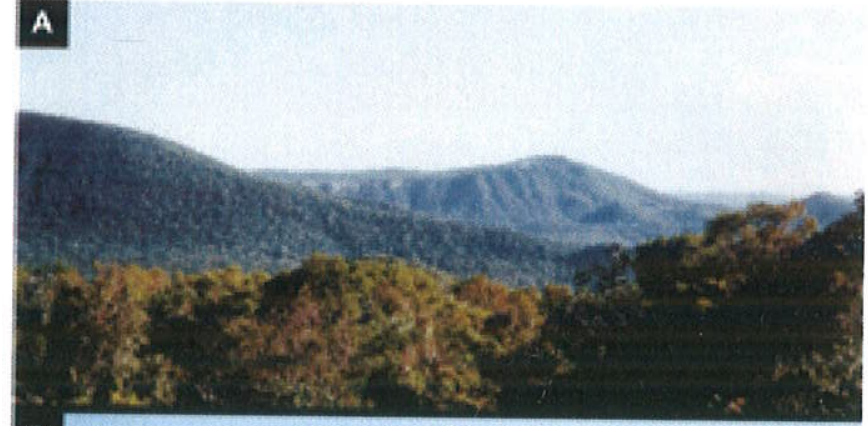

B

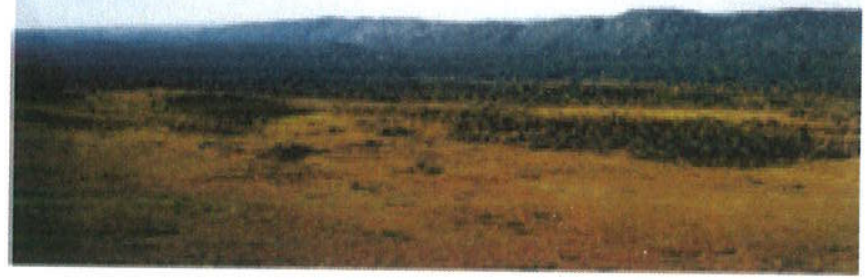

Fig. 9 - Escarpas do Planalto da Bodoquena: A- Escarpa ocidental, na região da Faz. Baía das Garças; B- Escarpa oriental, a sudoeste da Fazenda São Geraldo

- Bodoquena Plateau escarpments: A- Western scarp, near to the Baía das Garças Farm; B- Eastern scarp, in the southwest of São Geraldo Farm 
se assemelham muito com capturas, pois seguindo o gradiente hidráulico geral para E-SE, a tendência natural do Rio Perdido seria de correr para a bacia do Rio Miranda ou diretamente para o Rio Apa, a sul.

6- Estrutura linear que cruza a Serra da Bodoquena: Essa estrutura chama a atenção por ser um prolongamento da borda leste-sudeste do Pantanal, cruzando a Serra da Bodoquena com uma direção NE, no ponto onde foi descrita a segunda mudança de curso do rio perdido, e delimitando de uma forma geral planícies com morros isolados a norte e planícies praticamente sem morros a sul.

A ação de movimentos de blocos tectônicos compartimentando a Serra da Bodoquena é muito provável e sugerida pelas características morfológicas acima apontadas. Mas as evidências diretas da ação de falhas recentes na serra que delimitariam os blocos descritos acima ainda não foram encontradas. As evidências mencionadas não confirmam seguramente a ação direta da tectônica recente na Serra da Bodoquena. Falhas em depósitos quaternários não foram observadas, tampouco escarpas exibindo facetas triangulares, o que pode ter sido mascarado pelos processos intempéricos no carste.

\section{Considerações finais}

A região da Bodoquena possui extensas áreas carbonáticas, primeiramente investigadas regionalmente do ponto de vista geológico e geomorfológico por Almeida (1965). Este autor ressalta em suas conclusões uma incoerência entre as condições favoráveis para carstificação da região e a baixa incidência de feições cársticas notadas por ele.

Essa incoerência impulsionou em grande parte as recentes expedições espeleológicas na região, assim como, tornou-se uma questão importante do ponto de vista geocientífico, pois se há condições favoráveis, onde estariam os produtos da carstificação, ou então, quais são realmente os fatores determinantes para o pleno desenvolvimento de sistemas cársticos, com aqüíferos de condutos, cavernas e formas de relevo características.

Pesquisas em andamento (Sallun Filho, inédito, Tese de Doutoramento em preparação) estão revelando um quadro muito mais variado e complexo do carste da Bodoquena do que inicialmente esboçado por Almeida. Dois compartimentos principais são reconhecidos, com características contrastantes e opostas: setor norte com sistemas fluviais dominantes, epicarste exposto, alto entalhamento de rios e sistemas de circulação cárstica suspensos acima do nível de base dos rios, no Planalto da Bodoquena (Bacia do Rio Salobro) e setor sul (bacias dos rios Perdido e Miranda), com carste poligonal no Planalto da Bodoquena e amplas planícies cársticas apresentando agradação, feições vadosas de cavernas atualmente abaixo do NA (espeleotemas submersos) na Depressão do Rio Miranda. Também no setor sul há um aqüífero de condutos muito desenvolvido, com rotas de fluxo profundas e sis tema fluvial incipiente com baixo entalhamento de vales, tanto no Planalto da Bodoquena quanto na Depressão do Rio Miranda. Essas características morfológicas contrastantes são atribuídas a distintos regimes da tectônica Cenozóica destes setores, com soerguimento mais intenso no bloco norte e subsidência relativa no bloco sul.

Em relação às cavernas existe uma quantidade e uma variedade de padrões maior do que se tinha conhecimento, apesar de elas não serem tão abundantes quanto em outras regiões brasileiras. Existe ainda um potencial muito grande para explorações e estudos nas cavernas subaquáticas, visto que devem representar os maiores e mais completos sistemas de cavernas da Serra da Bodoquena.

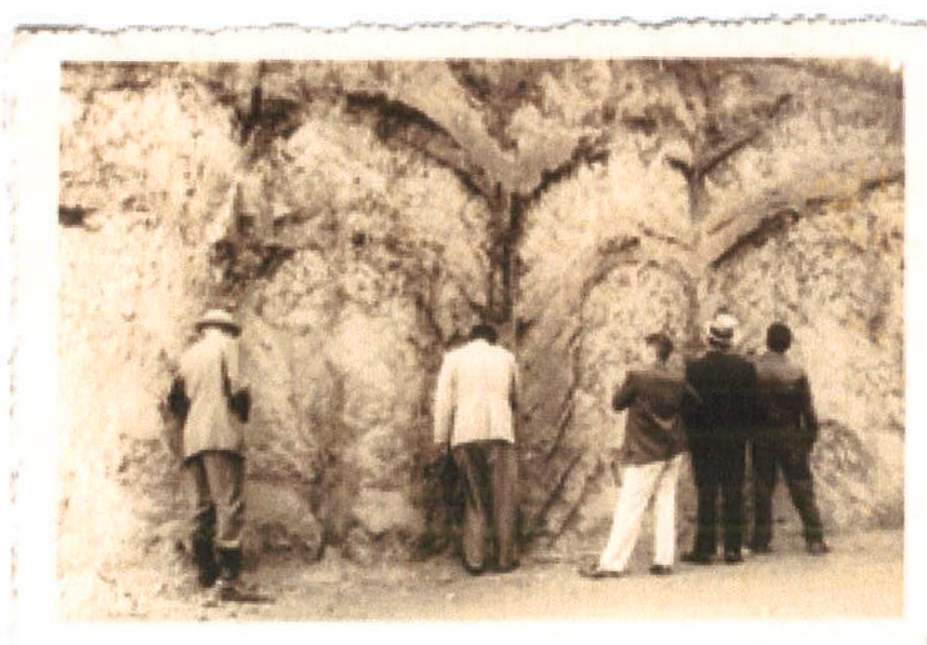


Anexo 3: Listagem dos mapas de cavernas obtidos.

$N^{\circ}$ SBE corresponde ao número de cadastro na Sociedade Brasileira de Espeleologia (SBE).

\begin{tabular}{|c|c|c|c|c|c|c|c|c|c|c|c|c|}
\hline $\begin{array}{l}N^{\circ} \\
\mathrm{SBE}\end{array}$ & Nome & Região / Municipio & Locallzação & Long. & Lat. & $\begin{array}{l}\text { Ait. } \\
\text { (m) }\end{array}$ & $\begin{array}{l}\text { Rlo ou } \\
\text { Lago }\end{array}$ & $\begin{array}{c}\text { Desenvolv. } \\
\text { (m) }\end{array}$ & $\begin{array}{l}\text { Desnivel } \\
\text { (m) }\end{array}$ & Topo & MAPA & Fonte \\
\hline 2 & Gruta do Lago Azul & Anhumas (Bonito) & - & 542497 & 7661787 & 429 & lago & 230 & 140 & $\underset{4 B}{S I M}$ & $\begin{array}{l}\text { SIM - } \\
\text { BOM }\end{array}$ & $\begin{array}{l}\text { Lino ef al. (1984); } \\
\text { Marcos Philadelphi }\end{array}$ \\
\hline 3 & $\begin{array}{l}\text { Gruta Nossa } \\
\text { Senhora de } \\
\text { Aparecida }\end{array}$ & Anhumas (Bonito) & Fazenda Jaraguá & 544222 & 7667680 & 430 & -..- & 200 & 55 & $\begin{array}{l}\text { SIM } \\
3 B\end{array}$ & $\begin{array}{l}\text { SiM - } \\
\text { BOM }\end{array}$ & Lino et al. (1984) \\
\hline 4 & Abismo Anhumas & Anhumas (Bonito) & Fazenda Anhumas & 541694 & 7660886 & 470 & lago & 189 & 105 & $\operatorname{SIM}_{4 \mathrm{C}}$ & $\begin{array}{l}\text { SIM - } \\
\text { BOM }\end{array}$ & $\begin{array}{l}\text { Auler et al. (2001); } \\
\text { Ayub et al. (1996); } \\
\text { Lino et al. }(1984)\end{array}$ \\
\hline 5 & $\begin{array}{l}\text { Gruta Morro do } \\
\text { Mateus }\end{array}$ & Bonito & $\begin{array}{l}\text { Morro do Mateus, } \\
\text { próx. à Bonito }\end{array}$ & 556918 & 7663139 & - & ـــــ & 96 & 26 & $\begin{array}{l}\operatorname{SiM} \\
3 B\end{array}$ & $\begin{array}{l}\text { SIM - } \\
\text { BOM }\end{array}$ & $\begin{array}{l}\text { Ayub et al. }(1996) ; \\
\text { Lino et al. }(1984)\end{array}$ \\
\hline 6 & Poço do Urubu & Bonito & $\begin{array}{c}\text { Morro do Mateus, } \\
\text { próx. à Bonito }\end{array}$ & ב-.... & - & - & -_- & 15 & 10 & $\begin{array}{l}\text { SiM } \\
3 A\end{array}$ & $\begin{array}{l}\text { SIM - } \\
\text { CROQUI }\end{array}$ & Lino et al. (1984) \\
\hline 9 & Gruta São Miguel & Anhumas (Bonito) & $\begin{array}{c}\text { Fazenda São } \\
\text { Miguel }\end{array}$ & 543551 & 7665877 & - & ــ & 180 & 30 & $\begin{array}{l}\text { SIM } \\
3 B\end{array}$ & $\begin{array}{l}\text { SIM - } \\
\text { BOM }\end{array}$ & Lino et al. (1984) \\
\hline 10 & Gruta Jaraguá & Anhumas (Bonito) & Fazenda Jaraguá & (-ב-ב- & $\ldots$ & 560 & - & 100 & 20 & $\begin{array}{l}\text { SIM } \\
3 B\end{array}$ & $\begin{array}{l}\text { SIM - } \\
\text { BOM }\end{array}$ & Lino et al. (1984) \\
\hline 11 & Buraco das Araras & Curé (Bonito/Jardim) & $\begin{array}{l}\text { Fazenda Costa } \\
\text { Rica }\end{array}$ & 561834 & 7623338 & 345 & lago & 125 & 60 & $\begin{array}{l}\text { SIM } \\
2 A\end{array}$ & $\begin{array}{c}\text { SIM - } \\
\text { CROQUI }\end{array}$ & Lino et al. (1984) \\
\hline 12 & Gruta do Mimoso & Mimoso (Bonito) & $\begin{array}{l}\text { Fazenda Alegria } \\
\qquad(\text { Mimoso) }\end{array}$ & 545829 & 7688659 & 440 & lago & 250 & 53 & $\begin{array}{l}\text { SIM } \\
4 C\end{array}$ & $\begin{array}{l}\mathrm{SIN}- \\
\mathrm{BOM}\end{array}$ & $\begin{array}{c}\text { Ayub et al. }(1996) \\
\text { Lino et al. }(1984) ; \\
\text { Leandro Dybal } \\
\text { Bertoni }\end{array}$ \\
\hline 13 & Gruta da Ametista & Mimoso (Bonito) & - & ב-ב_ב- & - & $\ldots$ & 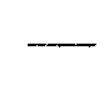 & 40 & 8 & $\underset{1 A}{S \mid M}$ & NÃO & Lino et al. (1984) \\
\hline 14 & Gruta João Arruda & Mimoso (Bonito) & $\begin{array}{c}\text { cabeceiras do Cór. } \\
\text { Genipapo }\end{array}$ & . & 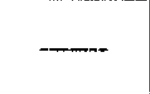 & 360 & $\underline{-}$ & 190 & 15 & $\begin{array}{c}\text { SIM } \\
3 \mathrm{~A}\end{array}$ & $\begin{array}{l}\text { SIM - } \\
\text { BOM }\end{array}$ & Lino et al. (1984) \\
\hline 15 & Gruta do Curé & Curé (Bonito/Jardim) & $\begin{array}{c}\text { Fazenda Santa } \\
\text { Maria (ex- Faz. do } \\
\text { Curê) } \\
\end{array}$ & 556666 & 7628631 & 290 & - ב-ב- & 80 & 25 & $\begin{array}{l}\text { SiM } \\
3 A\end{array}$ & $\begin{array}{l}\text { SIM - } \\
\text { BOM }\end{array}$ & Lino et al. (1984) \\
\hline
\end{tabular}




\begin{tabular}{|c|c|c|c|c|c|c|c|c|c|c|c|c|}
\hline 16 & Abismo do Poço & Curé (Bonito/Jardim) & $\begin{array}{c}\text { Fazenda Santa } \\
\text { Maria }\end{array}$ & 556994 & 7629792 & --- & lago & - & 20 & $\underset{4 B}{S I M}$ & $\begin{array}{l}\text { SIM - } \\
\text { CROQUI }\end{array}$ & $\begin{array}{c}\text { Gnaspini et al. } \\
(1994)\end{array}$ \\
\hline 17 & Gruta Serradinho & $\begin{array}{l}\text { Plan. Bodoquena } \\
\text { (Bonito) }\end{array}$ & $\begin{array}{l}\text { Fazenda } \\
\text { Serradinho }\end{array}$ & $-\ldots$ & 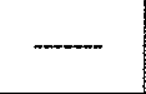 & - & $m$ & 100 & $m$ & $\mathrm{NADO}$ & NÄO & Lino et al. (1984) \\
\hline 18 & Gruta do Pindó & $\begin{array}{l}\text { Plan. Bodoquena } \\
\text { (Bonito) }\end{array}$ & $\begin{array}{c}\text { Fazenda Pindó de } \\
\text { Galno }\end{array}$ & 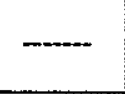 & - & $m$ & lago & 60 & 10 & $\begin{array}{l}\text { SIM } \\
2 B\end{array}$ & $\begin{array}{l}\text { SIM - } \\
\text { BOM }\end{array}$ & Lino ef al. (1984) \\
\hline 19 & Gruta Serrasul & $\begin{array}{l}\text { Plan. Bodoquena } \\
\text { (Bonito) }\end{array}$ & $\begin{array}{c}\text { antiga serraria } \\
\text { Serrasul }\end{array}$ & 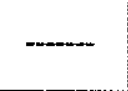 & - & - & - & 80 & 15 & NÃO & NAOO & Lino et al. (1984) \\
\hline 20 & Gruta Eldorado & $\begin{array}{c}\text { Plan. Bodoquena } \\
\text { (Bonito) }\end{array}$ & Fazenda Eldorado & - & -.-.- & -- & - & 150 & 30 & $\begin{array}{l}\text { SIM } \\
\text { TA }\end{array}$ & NẢO & Lino et al. (1984) \\
\hline 21 & $\begin{array}{l}\text { Gruta do Aito } \\
\text { Salobra }\end{array}$ & $\begin{array}{l}\text { Plan. Bodoquena } \\
\text { (Bonito) }\end{array}$ & $\begin{array}{c}\text { Fazenda Alto } \\
\text { Salobra }\end{array}$ & - & - & - & rio & 30 & - & NÃO & $N A \bar{O}$ & Lino et al. (1984) \\
\hline 22 & $\begin{array}{l}\text { Gruta Estreito da } \\
\text { Serra }\end{array}$ & Bodoquena & - & 530120 & 7739670 & 250 & (- & $\sim 188$ & 25,2 & $\operatorname{SIM}_{4 C}$ & $\begin{array}{l}\text { SIM - } \\
\text { CROQU! }\end{array}$ & $\begin{array}{c}\text { Gnaspini et al. } \\
(1994)\end{array}$ \\
\hline 23 & $\begin{array}{l}\text { Dolina Colônia } \\
\text { Seca }\end{array}$ & Bodoquena & $\ldots$ & 528900 & 7738300 & 172 & - & 68 & 15 & $\operatorname{SIM}_{4 \mathrm{C}}$ & $\begin{array}{l}\text { SIM - } \\
\text { CROQUI }\end{array}$ & $\begin{array}{c}\text { Gnaspini et al. } \\
(1994)\end{array}$ \\
\hline 24 & $\begin{array}{l}\text { Abismo do } \\
\text { Mandacaru }\end{array}$ & Bodoquena & -- & 528800 & 7737070 & 195 & 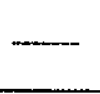 & - & 17 & $\begin{array}{l}\text { SIM } \\
2 \mathrm{C}\end{array}$ & $\begin{array}{l}\text { SIM - } \\
\text { CROQUI }\end{array}$ & $\begin{array}{c}\text { Gnaspini et al. } \\
\text { (1994) }\end{array}$ \\
\hline 25 & $\begin{array}{l}\text { Gruta de Santa } \\
\text { Maria }\end{array}$ & Curé (Bonito/Jardim) & (-..-- & 556708 & 7630101 & - & lagos & 253 & 24 & $\begin{array}{l}\mathrm{SIM} \\
4 \mathrm{~B}\end{array}$ & $\begin{array}{l}\text { SIM - } \\
\text { CROQUI }\end{array}$ & $\begin{array}{c}\text { Gnaspini et al. } \\
(1994)\end{array}$ \\
\hline 26 & Gruta do Cateto & Curé (Bonito/Jardim) & --.-- & 556707 & 7629793 & $\cdots$ & 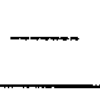 & 88 & 5 & $\underset{4 B}{S I M}$ & $\begin{array}{l}\text { SIM - } \\
\text { CROQUI }\end{array}$ & $\begin{array}{l}\text { Gnaspini et al. } \\
(1994)\end{array}$ \\
\hline 27 & $\begin{array}{l}\text { Gruta do X- } \\
\text { Coqueiro }\end{array}$ & Curé (Bonito/Jardim) & - & 556707 & 7629793 &.-- & - & 49 & 13 & $\begin{array}{l}\text { SIM } \\
4 B\end{array}$ & $\begin{array}{l}\text { SIM - } \\
\text { CROQUI }\end{array}$ & $\begin{array}{l}\text { Gnaspini et al. } \\
\text { (1994) }\end{array}$ \\
\hline 28 & $\begin{array}{l}\text { Gruta do Vale do } \\
\text { Prata }\end{array}$ & Curé (Bonito/Jardim) & - & 554980 & 7630107 & $\cdots$ & $\ldots$ & 543 & 28 & $\begin{array}{l}S i M \\
4 B\end{array}$ & $\begin{array}{l}\text { SIM - } \\
\text { CROQUI }\end{array}$ & $\begin{array}{c}\text { Gnaspini et al. } \\
\text { (1994) }\end{array}$ \\
\hline 29 & Gruta Dona Matilde & Curé (Bonito/Jardim) & 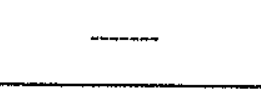 & 555267 & 7629798 & - & - & 246 & 46 & $\begin{array}{l}\text { SIM } \\
4 B\end{array}$ & $\begin{array}{l}\text { SIM - } \\
\text { CROQUI }\end{array}$ & $\begin{array}{l}\text { Gnaspini et al. } \\
\text { (1994) }\end{array}$ \\
\hline 30 & Gruta do Portal & Bonito & $\begin{array}{c}\text { Morro da Gr. do } \\
\text { Lago Azul }\end{array}$ & 543265 & 7663039 & $\cdots$ & rio & 245 & 33 & $\begin{array}{l}\operatorname{SiM} \\
4 B\end{array}$ & $\begin{array}{l}\text { SIM - } \\
\text { CROQUI }\end{array}$ & $\begin{array}{c}\text { Gnaspini et al. } \\
(1994)\end{array}$ \\
\hline 31 & Gruta do Guaviral & Bonito & $\begin{array}{l}\text { Morro da Gr. do } \\
\text { Lago Azul - Faz. } \\
\text { Zig-Zag }\end{array}$ & 541367 & 7662992 & - & - & 142 & 5 & $\begin{array}{l}\operatorname{SiM} \\
4 B\end{array}$ & $\begin{array}{c}\text { SIM - } \\
\text { CROQUI }\end{array}$ & $\begin{array}{c}\text { Ayub et al. (1996); } \\
\text { Gnaspini et al. } \\
(1994) \\
\end{array}$ \\
\hline
\end{tabular}




\begin{tabular}{|c|c|c|c|c|c|c|c|c|c|c|c|c|}
\hline 32 & $\begin{array}{l}\text { Abismo do Barro } \\
\text { Preto }\end{array}$ & Bonito & $\begin{array}{l}\text { Morro próx. ao } \\
\text { Abismo Anhumas }\end{array}$ & 540953 & 7661200 & $-\cdots$ & $\begin{array}{l}\text { lagos } \\
\text { (2) }\end{array}$ & $m$ & 17 & $\begin{array}{l}\text { SiM } \\
4 B\end{array}$ & $\begin{array}{c}\text { SIM - } \\
\text { CROQUI }\end{array}$ & $\begin{array}{c}\text { Gnaspini et al. } \\
(1994)\end{array}$ \\
\hline 33 & $\begin{array}{l}\text { Nascente do Rio } \\
\text { Formoso }\end{array}$ & Bonito & Fazenda Formoso & 537704 & 7649383 & 277 & sub (rio) & 565 & 89 & NÂO & $\begin{array}{l}\text { SIM - } \\
\text { CROQUI }\end{array}$ & $\begin{array}{c}\text { Grupo Bambui; } \\
\text { Presente trabalho }\end{array}$ \\
\hline 34 & Gruta da Harmonia & $\begin{array}{l}\text { Lau-de-Já/ Curvelo } \\
\text { (Bonito/Pto. } \\
\text { Murtinho) }\end{array}$ & FazendaHarmonia & 522477 & 7648323 & - M- & -...- & 235 & 6 & $\begin{array}{l}\mathrm{SIM} \\
4 \mathrm{~B}\end{array}$ & $\begin{array}{l}\text { SIM - } \\
\text { CROQU! }\end{array}$ & $\begin{array}{c}\text { Graspini et al. } \\
(1994)\end{array}$ \\
\hline 35 & $\begin{array}{l}\text { Gruta Santo } \\
\text { Antonio }\end{array}$ & $\begin{array}{c}\text { Lau-de-Já / Curvelo } \\
\text { (Bonito/Pto. } \\
\text { Murtinho) }\end{array}$ & - & 520774 & 7668616 & - & מ-בسב- & 67 & 3 & $\operatorname{SiM}_{4 B}$ & $\begin{array}{l}\text { SIM - } \\
\text { CROQUI }\end{array}$ & $\begin{array}{c}\text { Gnaspini et al. } \\
\quad(1994)\end{array}$ \\
\hline 36 & Gruta da Lagoinha & $\begin{array}{l}\text { Lau-de-Já / Curvelo } \\
\text { (Bonito/Pto. } \\
\text { Murtinho) }\end{array}$ & - & 520769 & 7664927 & --- & --- & 94 & 15 & $\operatorname{SIM}_{4 \mathrm{~B}}$ & $\begin{array}{l}\text { SIM - } \\
\text { CROQUI }\end{array}$ & $\begin{array}{c}\text { Gnaspini et al. } \\
(1994)\end{array}$ \\
\hline 37 & $\begin{array}{l}\text { Abismo da } \\
\text { Lagoinha }\end{array}$ & $\begin{array}{l}\text { Lau-de-Já / Curvelo } \\
\text { (Bonito/Pto. } \\
\text { Murtinho) }\end{array}$ & ----- & 520769 & 7664927 & - & - & - & $\sim 15$ & NÃO & $\begin{array}{l}\text { SIM - } \\
\text { CROQUI }\end{array}$ & $\begin{array}{l}\text { Gnaspini et al. } \\
\qquad(1994)\end{array}$ \\
\hline 38 & Gruta Pitangueiras & Mimoso (Bonito) & $\begin{array}{c}\text { Fazenda } \\
\text { Pitangueiras }\end{array}$ & 543180 & 7692218 & - & - & 558,3 & 19,8 & $\operatorname{SIM}_{4 \mathrm{C}}$ & $\begin{array}{l}\text { SIM - } \\
\text { BOM }\end{array}$ & $\begin{array}{c}\text { Ayub et al. (1996); } \\
\text { Gnaspini et al. } \\
\text { (1994); } \\
\text { Presente trabalho }\end{array}$ \\
\hline 39 & Gruta do Curvelo & $\begin{array}{l}\text { Lau-de-Já / Curvelo } \\
\text { (Bonito/Pto. } \\
\text { Murtinho) }\end{array}$ & ---- & 520739 & 7640947 & $\cdots$ & $\cdots$ & 601 & 8 & $\operatorname{SiM}_{4 B}$ & $\begin{array}{l}\text { SIM - } \\
\text { CROQUI }\end{array}$ & $\begin{array}{c}\text { Gnaspini et al. } \\
\text { (1994) }\end{array}$ \\
\hline 40 & $\begin{array}{l}\text { Gruta do } \\
\text { Curvelinho }\end{array}$ & $\begin{array}{l}\text { Lau-de-Já / Curvelo } \\
\text { (Bonito/Pto. } \\
\text { Murtinho) } \\
\end{array}$ & (-ב & 520739 & 7640947 & $\cdots$ & - & 211 & 4 & $\operatorname{SIM}_{4 B}$ & $\begin{array}{l}\text { SIM - } \\
\text { CROQUI }\end{array}$ & $\begin{array}{l}\text { Gnaspini et al. } \\
\text { (1994) }\end{array}$ \\
\hline 41 & $\begin{array}{l}\text { Toca Mestiça de } \\
\text { Baixo }\end{array}$ & $\begin{array}{l}\text { Lau-de-já / Curvelo } \\
\text { (Bonito/Pto. } \\
\text { Murikno) }\end{array}$ & - & 522470 & 7642789 & - & - & 8 & $m$ & $\begin{array}{l}\operatorname{SiM} \\
38\end{array}$ & NÃO & $\begin{array}{c}\text { Graspini et al. } \\
(1994)\end{array}$ \\
\hline 42 & $\begin{array}{l}\text { Toca Mestiça de } \\
\text { Cima }\end{array}$ & $\begin{array}{c}\text { Lau-de-Já / Curvelo } \\
\text { (Bonito/Pto. } \\
\text { Murtinho) }\end{array}$ & 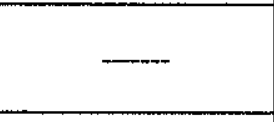 & 522470 & 7642789 & --- & --- & 10 & - & $\operatorname{SIM}_{3 \mathrm{~B}}$ & NÃO & $\begin{array}{l}\text { Gnaspini et al. } \\
\text { (1994) }\end{array}$ \\
\hline 43 & $\begin{array}{l}\text { Gruta Lagoa } \\
\text { Misteriosa }\end{array}$ & Jardim & $\begin{array}{c}\text { Fazenda Santa } \\
\text { Maria }\end{array}$ & 556748 & 7827057 & 270 & lago & 110 & 220 & & $\begin{array}{l}\text { SIM - } \\
\text { CROQUI }\end{array}$ & Gilberto Menezes \\
\hline 50 & Gruta do Antenor & Bodoquena & $\begin{array}{c}\text { Tarumâ, Faz. Sol } \\
\text { de Maio }\end{array}$ & 514094 & 7719286 & 400 & --_- & 63 & 7 & $\begin{array}{l}S I M \\
4 C\end{array}$ & $\begin{array}{l}\text { SIM - } \\
\text { CROQUI }\end{array}$ & UPE \\
\hline 51 & $\begin{array}{l}\text { Gruta Cateto } \\
\text { Sumido }\end{array}$ & Bodoquena & $\begin{array}{c}\text { Tarumâ, Faz. Sol } \\
\text { de Maio }\end{array}$ & 516382 & 7721620 & 386 & - & 287 & 17 & $\begin{array}{l}\text { SlM } \\
4 C\end{array}$ & $\begin{array}{l}\text { SIM - } \\
\text { CROQUI }\end{array}$ & UPE \\
\hline 52 & $\begin{array}{l}\text { Gruta Duas } \\
\text { Peladas }\end{array}$ & Bodoquena & $\begin{array}{c}\text { Tarumâ, Faz. Sol } \\
\text { de Maio }\end{array}$ & 514993 & 7721775 & 592 & $\ldots$ & 570 & 35 & $\operatorname{SIM}_{4 C}$ & $\begin{array}{l}\text { SIM - } \\
\text { CROQUI }\end{array}$ & UPE \\
\hline
\end{tabular}




\begin{tabular}{|c|c|c|c|c|c|c|c|c|c|c|c|c|}
\hline 53 & $\begin{array}{l}\text { Gruta da Pelada } \\
\text { Caida }\end{array}$ & Bodoquena & $\begin{array}{c}\text { Tarumâ, Faz. Sol } \\
\text { de Maio }\end{array}$ & & & 580 & - & 150 & 15 & NÃO & NÃO & UPE \\
\hline 54 & Gruta Vazada & Bodoquena & $\begin{array}{c}\text { Tarumâ, Faz. Sol } \\
\text { de Maio }\end{array}$ & & & 610 & $\cdots$ & 200 & $\cdots$ & NÃO & NÄO & UPE \\
\hline 55 & Gruta do Tamboré & Bodoquena & $\begin{array}{c}\text { Tarumâ, Faz. Sol } \\
\text { de Maio }\end{array}$ & & & 620 & - & 350 & - & NÃO & $N A ̈ O$ & UPE \\
\hline 56 & $\begin{array}{l}\text { Gruta Rapel do } \\
\text { Pau }\end{array}$ & Bodoquena & $\begin{array}{c}\text { Tarumâ, Faz. Sol } \\
\text { de Maio }\end{array}$ & & & 620 & -- & 600 & - & NÃO & NÃO & UPE \\
\hline 57 & $\begin{array}{l}\text { Gruta do Seu } \\
\text { Nicodemo }\end{array}$ & Bodoquena & $\begin{array}{c}\text { Tarumâ, Faz. Sol } \\
\text { de Maio }\end{array}$ & & & 621 & ב-..- & 18 & $\ldots$ & NÄO & NÄO & UPE \\
\hline 58 & $\begin{array}{l}\text { Gruta da Fazenda } \\
\text { Califómia }\end{array}$ & Bodoquena & $\begin{array}{c}\text { Tarumâ, Faz. Sol } \\
\text { de Maio }\end{array}$ & & & 634 & (-... & 400 & 30 & NÃO & NÃO & UPE \\
\hline 60 & $\begin{array}{l}\text { Gruta Córrego } \\
\text { Seco }\end{array}$ & Bonito & $\begin{array}{l}\text { Fazenda } \\
\text { Serradinho }\end{array}$ & 541440 & 7674313 & - & -- & 150,6 & 53,1 & $\operatorname{SIM}_{4 \mathrm{C}}$ & $\begin{array}{l}\text { SIM - } \\
\text { BOM }\end{array}$ & Ayub et al. (1996) \\
\hline 61 & Gruta Casa Nova & Bonito & $\begin{array}{c}\text { Fazenda Três } \\
\text { Morros }\end{array}$ & 528835 & 7669957 & - ע- & - & - & $\ldots$ & NĀO & NÃO & Ayub et al. (1996) \\
\hline 62 & Gruta da Pata & Bonito & $\begin{array}{c}\text { entre as faz. Cedro } \\
\text { e Olho D'água, na } \\
\text { propriedade da } \\
\text { Ped. Itaú } \\
\end{array}$ & 530945 & 7677681 & -- & $m$ & 57,4 & 1,5 & $\begin{array}{l}\operatorname{SiM} \\
4 C\end{array}$ & $\begin{array}{l}\text { SIM - } \\
\text { BOM }\end{array}$ & Ayub et al. (1996) \\
\hline 63 & Abismo Corpal & Bonito & $\begin{array}{l}\text { Fazenda } \\
\text { Serradinto }\end{array}$ & 533820 & 7674460 & 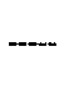 & -- & 58 & 12 & NÃO & NẢO & Ayub et al. (1996) \\
\hline 64 & $\begin{array}{l}\text { Gruta Fazenda } \\
\text { Serradinho }\end{array}$ & Bonito & $\begin{array}{l}\text { Fazenda } \\
\text { Serradinho }\end{array}$ & 533825 & 7674468 &.-- & $-\ldots$ & 125 & 1,5 & $\begin{array}{l}\operatorname{SIM} \\
4 C\end{array}$ & $\begin{array}{l}\text { SIM - } \\
\text { BOM }\end{array}$ & Ayub et al. (1996) \\
\hline 65 & Gruta do Periquito & Bonito & $\begin{array}{c}\text { Fazenda Santa } \\
\text { Tereza }\end{array}$ & 54623 & 7653370 & 463 & -- & 82,8 & 26,6 & $\mathrm{SIM}_{4 \mathrm{C}}$ & $\begin{array}{l}\text { SIM - } \\
\text { BOM }\end{array}$ & Ayub et al. (1996) \\
\hline 66 & $\begin{array}{l}\text { Gruta Casa de } \\
\text { Pedra }\end{array}$ & Bonito & $\begin{array}{c}\text { Fazenda Santa } \\
\text { Tereza }\end{array}$ & 545462 & 7676551 & - & $\ldots$ & 43 & 6 & $\operatorname{SIM}_{4 \mathrm{C}}$ & $\begin{array}{l}\text { SIM - } \\
\text { BOM }\end{array}$ & Ayub et al. (1996) \\
\hline 67 & Gruta Dom Bosco & Bonito & $\begin{array}{l}\text { Fazenda Dom } \\
\text { Bosco }\end{array}$ & 548600 & 7656415 & $\cdots$ & - & 23,8 & 8,3 & $\operatorname{SiM}_{4 \mathrm{C}}$ & $\begin{array}{l}\mathrm{SIM}- \\
\mathrm{BOM}\end{array}$ & Ayub et al. (1996) \\
\hline 68 & Gruta Monte Cristo & Bonito & $\begin{array}{l}\text { Fazenda Monte } \\
\text { Cristo }\end{array}$ & 548812 & 7658980 & --.- & $\ldots$ & $\ldots$ & $\ldots$ & NÄO & NÄO & Ayub et al. (1996) \\
\hline
\end{tabular}




\begin{tabular}{|c|c|c|c|c|c|c|c|c|c|c|c|c|}
\hline 89 & $\begin{array}{l}\text { Gruta Fazenda } \\
\text { América }\end{array}$ & Bonito & Fazenda América & 540410 & 7656388 & $\cdots$ & - & -..- & -.... & $\operatorname{SIM}_{4 \mathrm{C}}$ & $\begin{array}{l}\text { SIM - } \\
\text { BOM }\end{array}$ & Ayub et al. (1996) \\
\hline 70 & Gruta da Coruja & Bonito & $\begin{array}{c}\text { Fazenda Santa } \\
\text { Tereza }\end{array}$ & 545421 & 7676111 & - & 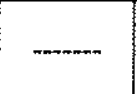 & (- & (2) & NÄO & $N A ̋ O$ & Ayub ef al. (1986) \\
\hline 71 & $\begin{array}{l}\text { Gruta das } \\
\text { Borboletas }\end{array}$ & Bonito & Fazenda Bocaiúva & 545900 & 7679200 & - & - & 34,8 & 16,4 & NÃO & NÃO & Ayub et al. (1996) \\
\hline 72 & $\begin{array}{l}\text { Gruta Fazenda } \\
\text { Santo Antônio }\end{array}$ & Bonito & $\begin{array}{l}\text { Fazenda Santo } \\
\text { Antônio }\end{array}$ & 557337 & 7669672 & - & $-\cdots$ & $230(? ? ?)$ & $30(? ? ?)$ & NÄO & NÃO & Ayub et al. (\$996) \\
\hline 73 & Gruta Opossum & Bonito & Fazenda Bocaiúva & 545835 & 7679361 & 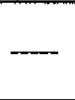 & lago & 40 & 50 & $\operatorname{SiM}_{4 C}$ & $\begin{array}{l}\text { SIM - } \\
\text { BOM }\end{array}$ & Presente trabalho \\
\hline 76 & $\begin{array}{l}\text { Gruta da } \\
\text { Taboquinha }\end{array}$ & Bonito & $\begin{array}{l}\text { Fazenda } \\
\text { Taboquinha }\end{array}$ & 557318 & 7696331 & $-m$ & -..-- & - & - & NĀO & $N A \bar{O}$ & Ayub ef al. (1996) \\
\hline$\pi$ & $\begin{array}{l}\text { Buraco do Japonês } \\
\text { ou Fósseis }\end{array}$ & Jardim & Fazenda Guará & 535204 & 7612051 & - & $\operatorname{sub}($ rio) & 231 & 43,25 & $S \mid M$ & $\begin{array}{l}\text { SIM - } \\
\text { CROQUI }\end{array}$ & Marcus Werneck \\
\hline 78 & $\begin{array}{l}\text { Buraco das } \\
\text { Abelhas }\end{array}$ & Jardim & Fazenda Figueira & - & -m & - & sub (rio) & 1900 & 58 & $\operatorname{SIM}$ & $\begin{array}{l}\text { SIM - } \\
\text { CROQUI }\end{array}$ & Afonso Pinheiro Jr. \\
\hline 79 & $\begin{array}{l}\text { Nascente da } \\
\text { Ceita-Curê }\end{array}$ & Bonito & $\begin{array}{l}\text { Fazenda Ceita- } \\
\text { Curê }\end{array}$ & 542328 & 7695395 & 419 & sub (rio) & 30 & 153 & $\operatorname{Sin} 4$ & $\begin{array}{l}\text { SIM - } \\
\text { BOM }\end{array}$ & $\begin{array}{l}\text { Leandro Dybal } \\
\text { Bertoni }\end{array}$ \\
\hline 80 & Gruta Beija-Flor & Bodoquena & Fazenda Califórnia & 515310 & 7712814 & 520 & rio & 177 & 25 & $\begin{array}{l}\text { SIM } \\
4 C\end{array}$ & $\begin{array}{l}\text { SIM - } \\
\text { BOM }\end{array}$ & Presente trabalho \\
\hline 81 & $\begin{array}{l}\text { Gruta Toca da } \\
\text { Onça }\end{array}$ & Bodoquena & $\begin{array}{l}\text { Fazenda Ouro } \\
\text { Verde (?) }\end{array}$ & 519050 & 7708308 & 420 & $\operatorname{sub}($ rio) & - & 0 & NĀO & $N A ̄ O$ & Presente trabaiho \\
\hline 82 & Gruta Califómia & Bodoquena & Fazenda Califórnia & 516044 & 7710816 & 419 & -...- & 250 & 15 & $\begin{array}{l}\text { SIM } \\
4 C\end{array}$ & $\begin{array}{l}\text { SIM - } \\
\text { BOM }\end{array}$ & Presente trabalho \\
\hline 83 & Gruta Guaicurus & Bonito & $\begin{array}{l}\text { Assentamento } \\
\text { Guaicurus }\end{array}$ & 516052 & 7684683 & 652 & - & 81 & 18 & $\begin{array}{l}S I M \\
4 C\end{array}$ & $\begin{array}{l}\text { SIM - } \\
\text { BOM }\end{array}$ & Presente trabalho \\
\hline 85 & Gruta Urubu Rei & Bodoquena & Morraria & 515421 & 7733836 & 279 & rio & 473 & 3,7 & $\underset{4 C}{S I M}$ & $\begin{array}{l}\text { SIM - } \\
\text { BOM }\end{array}$ & Presente trabalho \\
\hline 86 & Gruta da Onça & Jardim & Fazenda Santa Fé & 525170 & 7623306 & 546 & 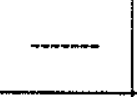 & 161 & $\{3,7$ & $\operatorname{SIM}_{4 \mathrm{C}}$ & $\begin{array}{l}\text { SIM - } \\
\text { BOM }\end{array}$ & Presente trabalho \\
\hline 87 & Gruta José Cesário & Bonito & $\begin{array}{l}\text { Assentamento } \\
\text { Guaicurus }\end{array}$ & 517292 & 7688354 & 610 & - & 20 & - & NÃO & NÂO & Presente trabalho \\
\hline
\end{tabular}




\begin{tabular}{|c|c|c|c|c|c|c|c|c|c|c|c|c|}
\hline 88 & Gruta do Haroldo & Bonito & $\begin{array}{l}\text { Assentamento } \\
\text { Guaicurus }\end{array}$ & 514530 & 7685028 & 649 & - & 172 & 7 & $\begin{array}{l}\text { SIM } \\
4 C\end{array}$ & $\begin{array}{l}\text { SIM - } \\
\text { BOM }\end{array}$ & Presente trabatho \\
\hline 89 & $\begin{array}{l}\text { Gruta Cinco de } \\
\text { Ouros }\end{array}$ & Bodoquena & $\begin{array}{l}\text { Assentamento } \\
\text { Campina }\end{array}$ & 528738 & 7725322 & 336 & lago & 230 & 18 & $\operatorname{SIM}_{4 C}$ & $\begin{array}{l}\text { SIM - } \\
B O M\end{array}$ & Presente trabaiho \\
\hline 90 & $\begin{array}{l}\text { Gruta Manoe! } \\
\text { Carcoso }\end{array}$ & Bodoquena & $\begin{array}{c}\text { Assentamento } \\
\text { Campina }\end{array}$ & 528931 & 7725566 & 315 & lago & 80 & 11 & $\operatorname{SIM}_{4 C}$ & $\begin{array}{l}\text { SIM - } \\
\text { BOM }\end{array}$ & Presente trabalho \\
\hline 91 & Gruta Benedita & Bodoquena & $\begin{array}{l}\text { Assentamento } \\
\text { Campina }\end{array}$ & 528923 & 7725774 & 333 & -.-- & 180 & 27 & $\begin{array}{l}\text { SIM } \\
4 C\end{array}$ & $\begin{array}{l}\text { SIM - } \\
\text { BOM }\end{array}$ & Presente trabaiho \\
\hline 93 & Gruta do Alex & Bodoquena & $\begin{array}{l}\text { Assentamento } \\
\text { Campina }\end{array}$ & 530298 & 7721391 & 335 & - & (-.... & - & (20) & - & $\begin{array}{l}\text { Wanderlei R. de } \\
\text { Souza }\end{array}$ \\
\hline 94 & Gruta do Alex 2 & Bodoquena & $\begin{array}{l}\text { Assentamento } \\
\text { Campina }\end{array}$ & 530318 & 7721546 & 335 & 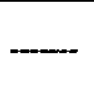 & ט-בسב- & $\ldots$ & 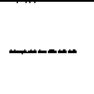 & 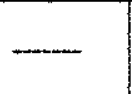 & $\begin{array}{l}\text { Wanderlei R. de } \\
\text { Souza }\end{array}$ \\
\hline 95 & Gruta do Alex 3 & Bodoquena & $\begin{array}{l}\text { Assentamento } \\
\text { Campina }\end{array}$ & 530238 & 7721554 & 355 & ב-ביבדי & (- & $\underline{-1}$ & $-\cdots$ & $\rightarrow$ & $\begin{array}{l}\text { Wanderlei R. de } \\
\text { Souza }\end{array}$ \\
\hline 96 & $\begin{array}{l}\text { Caverna Santa } \\
\text { Luzia }\end{array}$ & Bodoquena & $\begin{array}{l}\text { Assentamento } \\
\text { Campina }\end{array}$ & 522856 & 7724030 & 330 & - & ----- & $\ldots$ & - & $\ldots$ & $\begin{array}{c}\text { Wanderlei R. de } \\
\text { Souza }\end{array}$ \\
\hline 97 & $\begin{array}{l}\text { Abismo Coronel } \\
\text { Chico Mineiro }\end{array}$ & Bodoquena & $\begin{array}{l}\text { Assentamento } \\
\text { Campina }\end{array}$ & 528892 & 7724092 & 335 & --ב- & -non & $\ldots$ & $\ldots$ & $\ldots$ & $\begin{array}{c}\text { Wanderlei R. de } \\
\text { Souza }\end{array}$ \\
\hline 98 & Caverna Betel & Bodoquena & $\begin{array}{l}\text { Assentamento } \\
\text { Campina }\end{array}$ & 523165 & 7723428 & 330 & $\ldots$ & ב._. & - & -...- & $\ldots$ & $\begin{array}{l}\text { Wanderlei R. de } \\
\text { Souza }\end{array}$ \\
\hline 99 & $\begin{array}{l}\text { Caverna Quatro } \\
\text { Irmãos }\end{array}$ & Bodoquena & $\begin{array}{l}\text { Assentamento } \\
\text { Campina }\end{array}$ & 529562 & 7723284 & 315 & - & $\ldots$ & $\ldots$ & (2. & $\ldots$ & $\begin{array}{l}\text { Wanderlei R. de } \\
\text { Souza }\end{array}$ \\
\hline 100 & Caverna Tiago & Bodoquena & $\begin{array}{l}\text { Assentamento } \\
\text { Campina }\end{array}$ & 528884 & 7724666 & 320 & - & 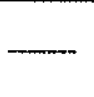 & - & $\ldots$ & $\ldots$ & $\begin{array}{l}\text { Wanderlei R. de } \\
\text { Souza }\end{array}$ \\
\hline 101 & $\begin{array}{l}\text { Caverna Quatro } \\
\text { lrmãos } 2\end{array}$ & Bodoquena & $\begin{array}{l}\text { Assentamento } \\
\text { Campina }\end{array}$ & 529596 & 7723346 & 325 & -- & ــــ & ב-ב- & $-\cdots$ & - & $\begin{array}{c}\text { Wanderlei R. de } \\
\text { Souza }\end{array}$ \\
\hline
\end{tabular}




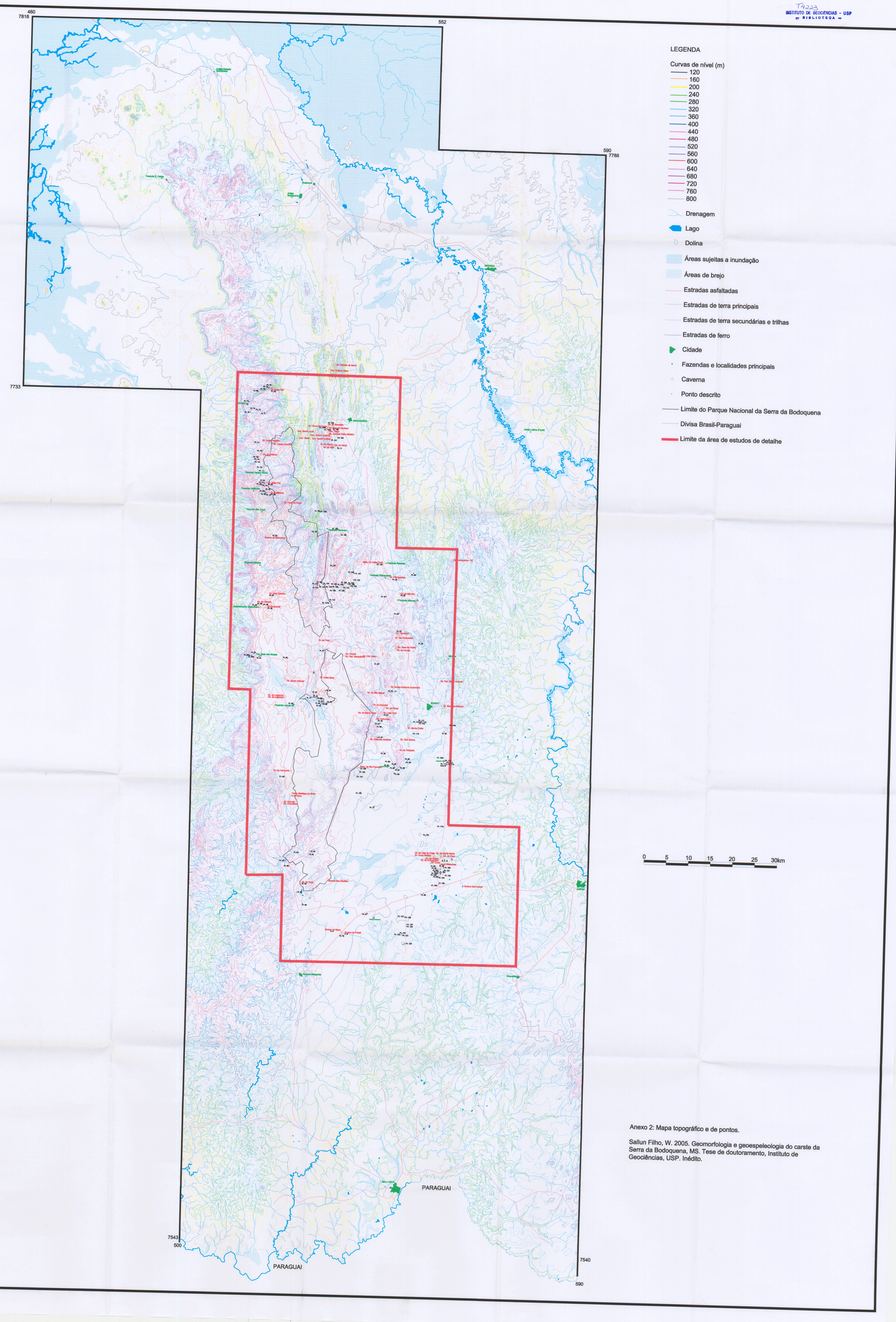


Anexo 4: Mapa geomorfológico.

Anexo 5a: Mapa geológico da área de detalhe. Compilado de Nogueira \& Oliveira, 1978; Neto et al., 1976; Araújo et al., 1982; Godoi, 2001).

Anexo 5b: Perfís geológicos e dados estruturais. Perfis compilados de Nogueira \& Oliveira, 1978; Godoi, 2001). 


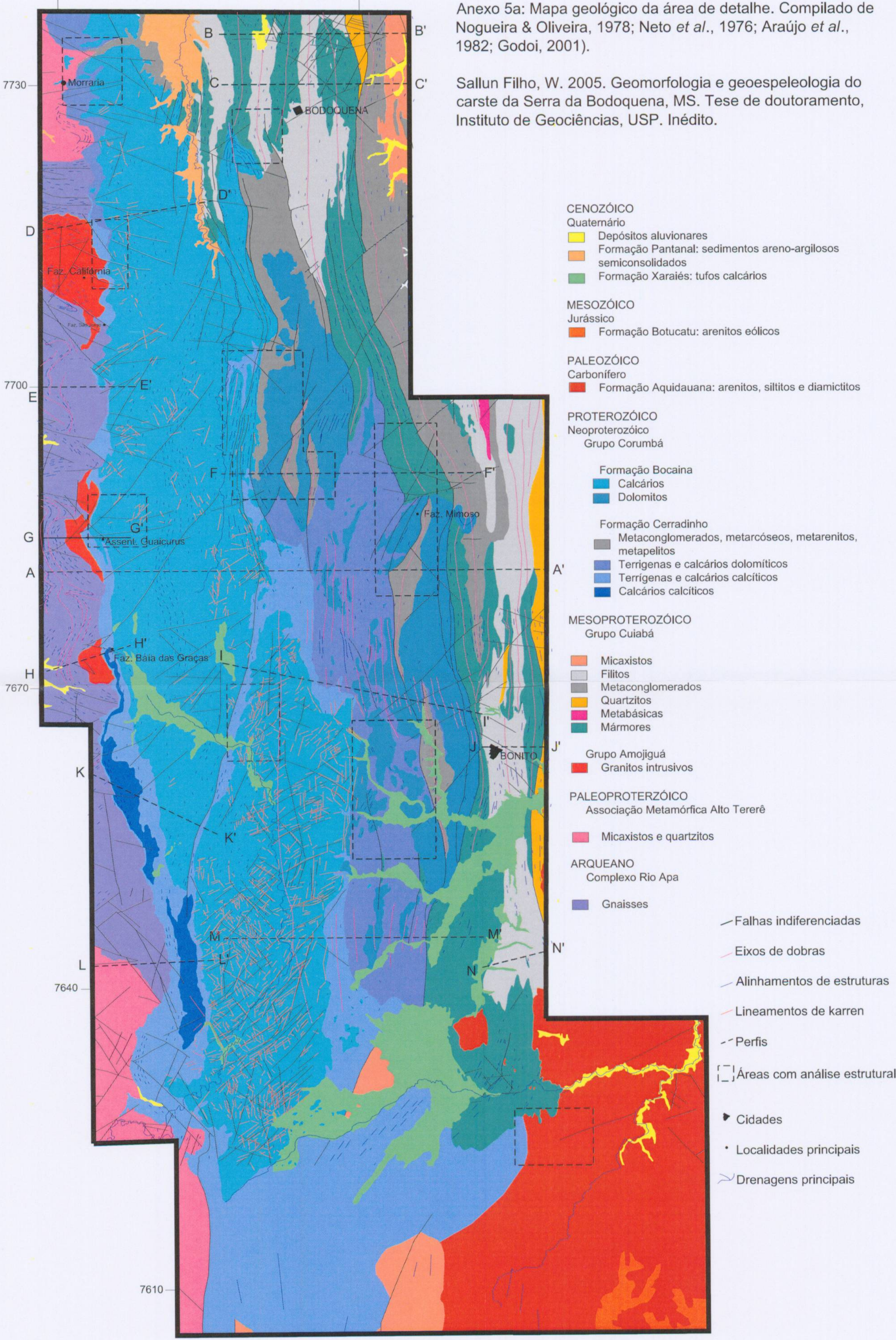

Anexo 5a: Mapa geológico da área de detalhe. Compilado de Nogueira \& Oliveira, 1978; Neto et al., 1976; Araújo et al.

Formação Pantanal: sedimentos areno-argilosos semiconsolidados

MESOZÓıcO

Jurássico

PALEOZÓICO

Carbonifero

ROzóı́co

Formação Bocaina

Calcários

Dolomitos

Formação Cerradinho

Metaconglomerados, metarcóse

Filitos

Metaconglomerados

Quartzitos

Grupo Amojigua

EOPROTERZOICO

Associação Metamórfica Alto Terere

Micaxistos e quartzitos

RQUEANO

Complexo Rio Apa

Gnaisses

Falhas indiferenciadas

--Perfis

-'Áreas com análise estrutura

Cidades

Localidades principais

Drenagens principais 


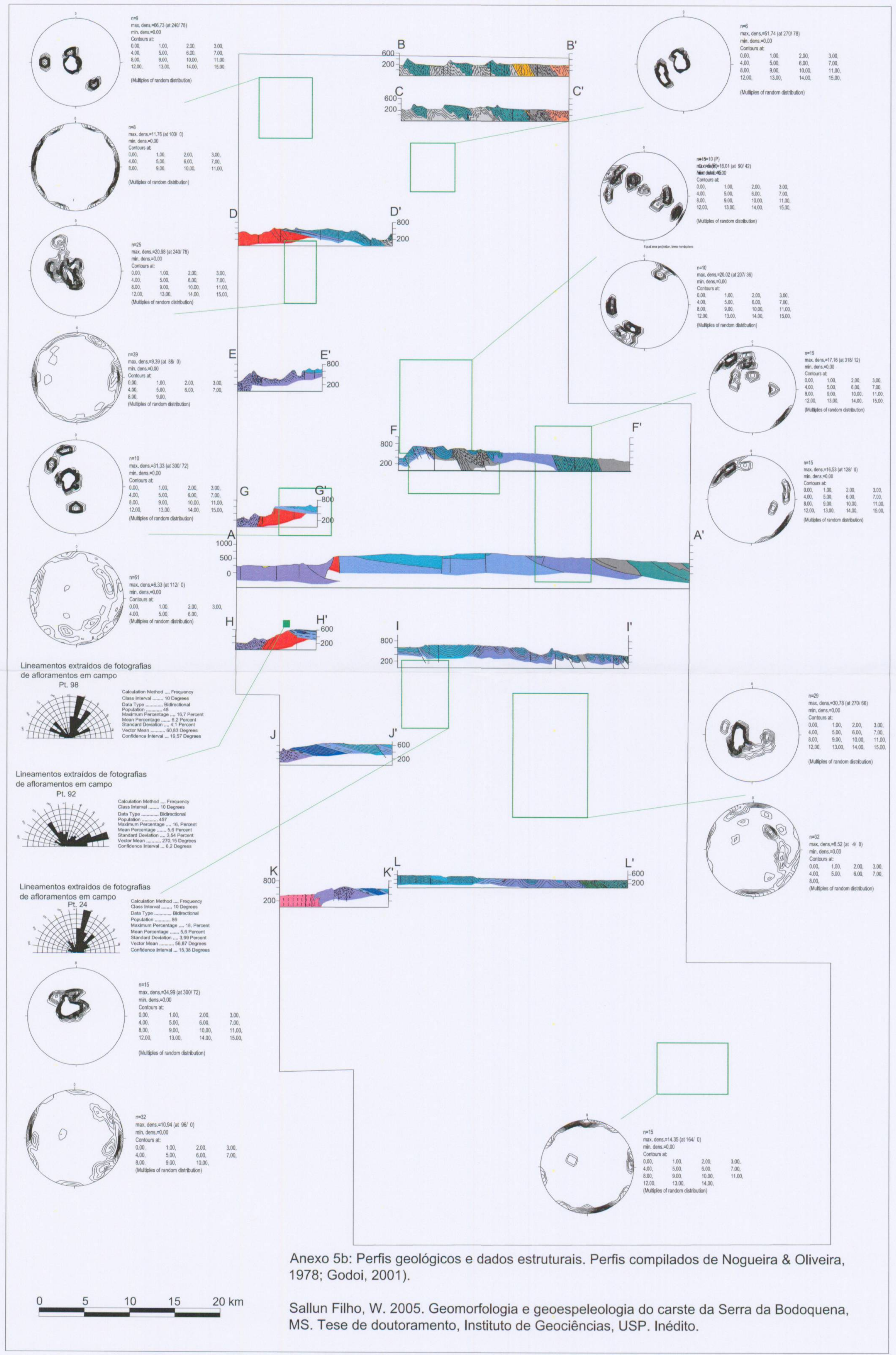




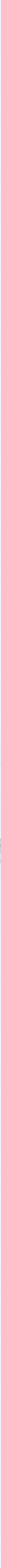


O CD-ROM ENCONTRA-SE NO SETOR DE REFERÊNCIA

Anexo 6: Mapas completos das cavernas em CD-ROM (arquivos em Adobe Acrobat). 